Energy Systems Environmental Restoration Program ORNL Environmental Restoration Program

\title{
Work Plan for the Isotopes Facilities Deactivation Project at Oak Ridge National Laboratory
}

Date Issued-May 1995

Prepared by

Isotopes Facilities Deactivation Project Environmental Restoration Division Oak Ridge National Laboratory

Prepared for U.S. Department of Energy Office of Environmental Management under budget and reporting code EW 20

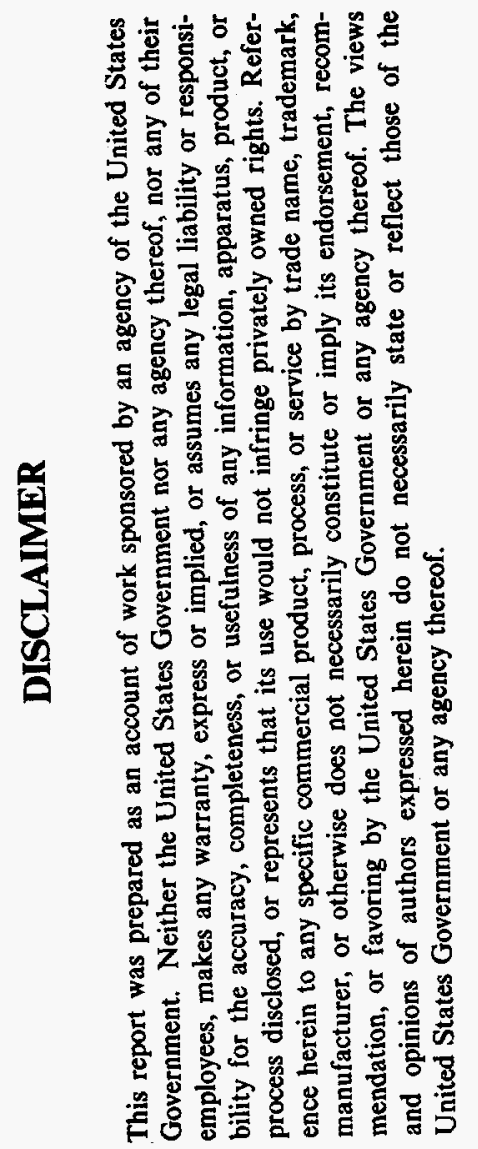

Environmental Restoration and Waste Management Programs

Oak Ridge National Laboratory

Oak Ridge, Tennessee 37831-6285 managed by

MARTIN MARIETTA ENERGY SYSTEMS, INC. for the U.S. DEPARTMENT OF ENERGY under contract DE-AC05-84OR21400 
-

-

• 


\section{DISCLAIMER}

Portions of this document may be illegible in electronic image products. Images are produced from the best available original document. 


\section{CONTENTS}

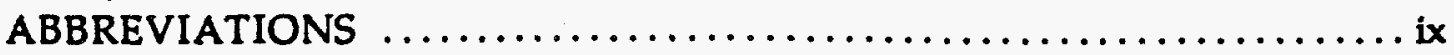

EXECUTIVE SUMMARY $\ldots \ldots \ldots \ldots \ldots \ldots \ldots \ldots \ldots \ldots \ldots \ldots \ldots \ldots \ldots$

1. INTRODUCTION $\ldots \ldots \ldots \ldots \ldots \ldots \ldots \ldots \ldots \ldots \ldots \ldots \ldots \ldots \ldots$

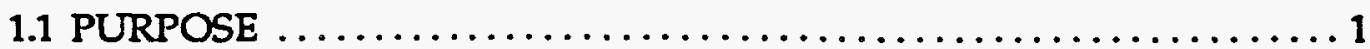

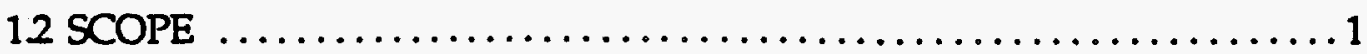

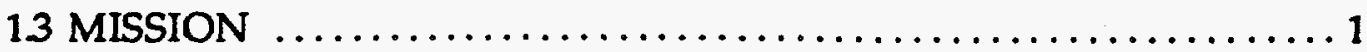

2 PROJECT OBJECTIVES AND APPROACH $\ldots \ldots \ldots \ldots \ldots \ldots \ldots \ldots \ldots$

21 PROJECT OBJECTIVES $\ldots \ldots \ldots \ldots \ldots \ldots \ldots \ldots \ldots \ldots \ldots \ldots \ldots \ldots \ldots \ldots \ldots$

2.1.1 Environment, Safety, and Health Objectives .............

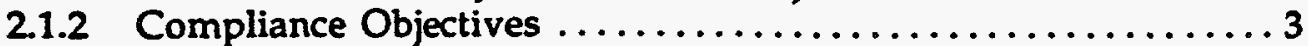

2.1.3 EM-60/EM-40 Transition Objectives .................

2.1.4 Waste Management Objectives ..................

2.1.5 Life Cycle Cost and Risk Objectives $\ldots \ldots \ldots \ldots \ldots \ldots \ldots \ldots$

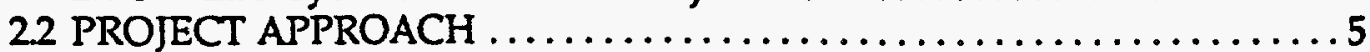

2.2.1 General Technical Requirements ................ 5

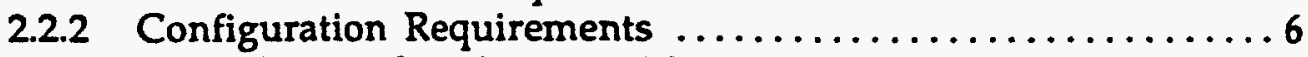

2.2.3 Hazardous and Radioactive Materials

Removal/Stabilization Requirements .............6

2.2.4 Surveillance and Maintenance Requirements ........... 7

2.3 FACILITY DEACTIVATION PROCESS .................. 9

2.3.1 Deactivation Activities . . . . . . . . . . . . . . . . . . . 12

2.3.2 Facility-Specific Deactivation Work Plan Activities .......... 14

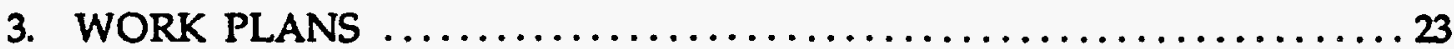

3.1 WORK BREAKDOWN STRUCTURE $\ldots \ldots \ldots \ldots \ldots \ldots \ldots \ldots \ldots \ldots . \ldots \ldots$

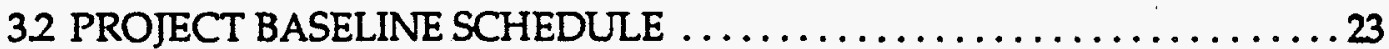

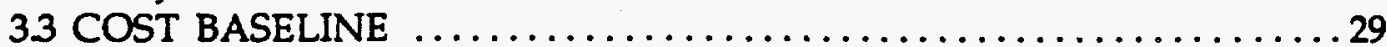

3.4 PROJECT ORGANIZATION AND RESPONSIBILITIES ......... 32

3.4.1 ORNL Environmental Restoration Program ............ 32

3.4.2 Chemical Technology Division .................. 32

3.4.3 Plant and Equipment Division $\ldots \ldots \ldots \ldots \ldots \ldots \ldots \ldots \ldots \ldots \ldots \ldots \ldots \ldots$

3.4.4 Instrumentation and Controls Division $\ldots \ldots \ldots \ldots \ldots \ldots 33$

3.4.5 Office of Radiation Protection $\ldots \ldots \ldots \ldots \ldots \ldots \ldots \ldots \ldots \ldots \ldots \ldots \ldots \ldots$

3.4.6 Center for Risk Management ..................... 34

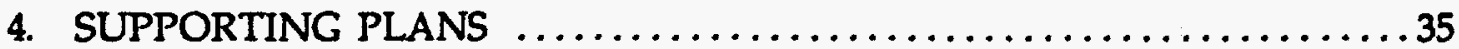

4.1 SURVEILLANCE AND MAINTENANCE $\ldots \ldots \ldots \ldots \ldots \ldots \ldots \ldots \ldots$

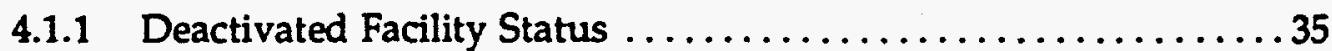

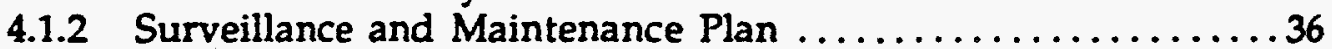

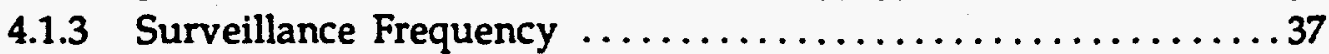

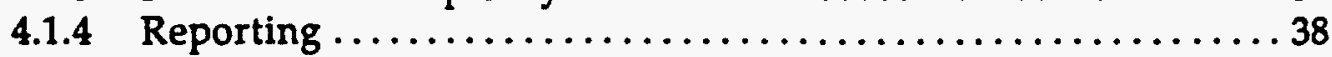

42 SAFETY DOCUMENTATION PLAN $\ldots \ldots \ldots \ldots \ldots \ldots \ldots \ldots \ldots$ 
4.2.1 Status of Existing Safety Documentation ................... 39

4.2.2 Description and status of Safety Analysis Report

Upgrade Program ................................ 39

4.2.3 Unreviewed Safety Question Determination

Process and Status ..........................43

4.2.4 Description of Problem Safety Summary Report .......... 43

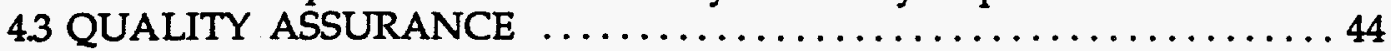

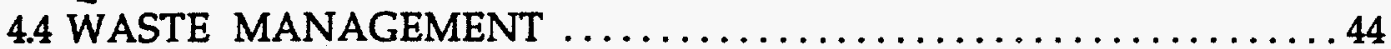

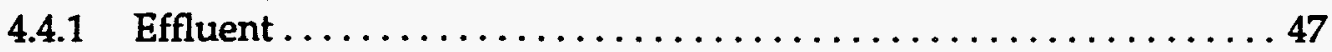

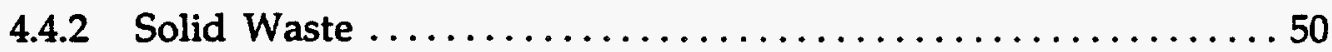

4.4.3 Waste Minimization ........................ 52

4.5 NATIONAL ENVIRONMENTAL POLICY ACT

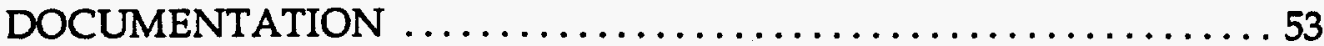

4.6 ENVIRONMENT, SAFETY, AND HEALTH $\ldots \ldots \ldots \ldots \ldots \ldots \ldots \ldots 53$

4.7 DOCUMENTATION AND RECORDS $\ldots \ldots \ldots \ldots \ldots \ldots \ldots \ldots \ldots . \ldots \ldots$

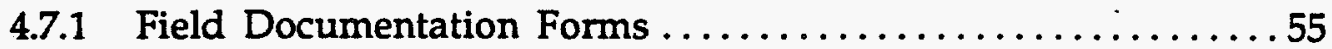

4.7 .2 Quality Records ........................... 55

Appendix A. DESCRIPTION AND HISTORY OF FACILITIES $\ldots \ldots \ldots \ldots \ldots$ A-1

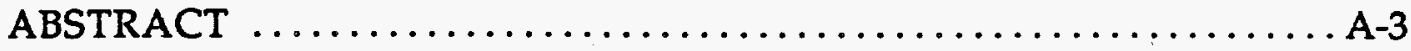

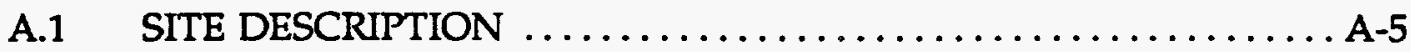

A.2 DESCRIPTION OF FACILITIES . . . . . . . . . . . . A-9

A.2.1 BUILDING 3026-C-KRYPTON-85 ENRICHMENT

FACILITY . . .......................... A

A.2.2 BUILDING 3026-D-SEGMENTING HOT CELL FACILITY . . . . A A-12

A.2.3 BUILDING 3028-ALPHA POWDER FACILITY ........... A-15

A.2.4 BUILDING 3029-SOURCE DEVELOPMENT

LABORATORY ........................... A-19

A.2.5 BUILDINGS 3030/3031/3118-RADIOISOTOPES

PRODUCTION LABORATORIES C, D, AND H . . . . . . . . . A-24

A.2.6 BUILDING 3033-TRITIUM AND KRYPTON

PRODUCTION FACILITY $\ldots \ldots \ldots \ldots \ldots \ldots \ldots \ldots \ldots \ldots . . \ldots$ A-31

A.2.7 BUILDING 3033-A-ACTINIDE FABRICATION FACILITY . . . . A-36

A.2.8 BUILDING 3038-ISOTOPES RESEARCH MATERIALS

LABORATORY, ISOTOPES SHIPPING, ISOTOPES

TECHNOLOGY, AND ALPHA HANDLING FACILITY . . . . . A A-42

A.2.9 BUILDING 3047-RADIOISOTOPES DEVELOPMENT

LABORATORY ............................ A -52

A.2.10 BUILDING 3517-FISSION PRODUCT DEVELOPMENT

LABORATORY .......................... A-68

A.2.11 BUILDING 7025-TRITIUM TARGET FABRICATION $\ldots \ldots \ldots$ A-73

A.2.12 BUILDING 9204-3-ACTINIDE AREA ............... A-82

Appendix B. PROJECT SCHEDULES $\ldots \ldots \ldots \ldots \ldots \ldots \ldots \ldots \ldots \ldots \ldots$ B-1

Appendix C. PROJECT COST ESTMMATES $\ldots \ldots \ldots \ldots \ldots \ldots \ldots \ldots \ldots \ldots$ C-1 


\section{FIGURES}

ES-1 Isotopes Facilities Deactivation Project schedule $\ldots \ldots \ldots \ldots \ldots \ldots \ldots$ xi

1 Deactivation process for surplus facilities $\ldots \ldots \ldots \ldots \ldots \ldots \ldots \ldots \ldots$

2 IFDP Work Breakdown Structure ........................... 24

3 Isotopes Facilities Deactivation Project shedule .............. 27

4 Safety Analysis Report Update Program $\ldots \ldots \ldots \ldots \ldots \ldots \ldots \ldots \ldots \ldots$

5 Example of Problem Safety Summary $\ldots \ldots \ldots \ldots \ldots \ldots \ldots \ldots \ldots \ldots$

A.1 Location of Isotopes Facilities at ORNL $\ldots \ldots \ldots \ldots \ldots \ldots \ldots \ldots \ldots \ldots$

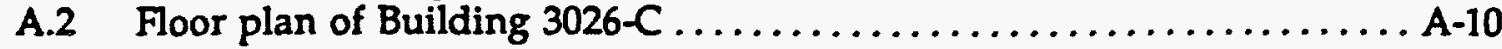

A.3 Floor plan of Building 3028-Alpha Powder Facility and

Short-Lived Fission Product Facility .................... A-17

A.4 Floor plan of Building 3029-Source Development Laboratory ....... A-23

A.5 Floor plan of Building 3030-Radioisotope Development Facility .... . A-29

A.6 Floor plan of Building 3031-Radioisotope Development Facility .... A A-30

A.7 Floor plan of Building 3033-Tritium and Krypton

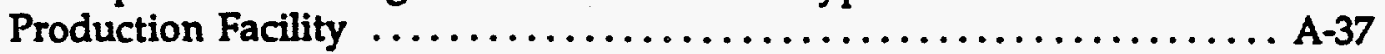

A.8 Floor plan of Building 3033-A-Actinide Fabrication Facility ....... A-41

A.9 Floor plan of east-end laboratory in Building $3038 \ldots \ldots \ldots \ldots \ldots \ldots$ A-45

A.10 Floor plan of Radioactive Materials Shipping and Packaging

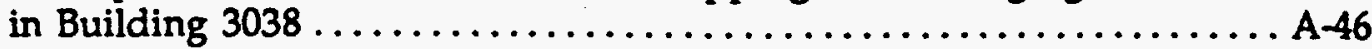

A.11 Floor plan of Isotope Technology Laboratories in Building $3038 \ldots . .$. A-47

A.12 Low-level laboratory ............................. A-49

A.13 Floor plan of Alpha Handling Facility in Building $3038 \ldots \ldots \ldots \ldots$ A-50

A.14 Receiving area ................................. A 51

A.15 Floor plan of Building 3047-Radioisotope Development Laboratory . A A-58

A.16 Floor plan of Building 3517-Fission Product Development

Laboratory ................................. A 69

A.17 Floor plan of Building 7025-Tritium Target Fabrication . . . . . . . A-81

A.18 Floor plan of Actinide Area in Building 9204-3, second floor east, showing the calutron operations and the equipment wash and

service areas 



\section{TABLES}

ES-1 Isotopes Facilities Deactivation Project cost summary $\ldots \ldots \ldots \ldots \ldots$ xi

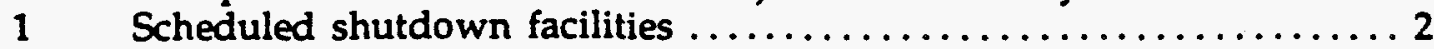

2 Isotopes Facilities Deactivation Project milestones $\ldots \ldots \ldots \ldots \ldots \ldots 28$

3 Isotopes Facilities Deactivation Project cost summary ........... 30

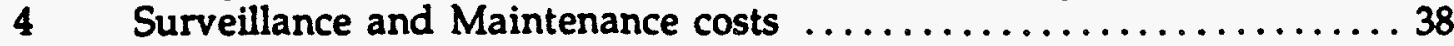

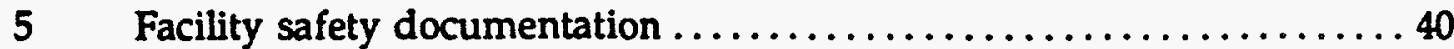

6 Building 3039 stack cell ventilation service for buildings in the Isotopes Facilities Deactivation Project ................ 48

$7 \quad$ Liquid low-level waste collection tank service for buildings in the Isotopes Facilities Deactivation Project $\ldots \ldots \ldots \ldots \ldots \ldots \ldots$

8 Solid waste volume estimates for deactivation of

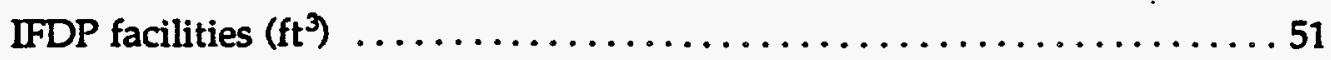

A.1 Building 3026-C - general status of facility $\ldots \ldots \ldots \ldots \ldots \ldots \ldots \ldots \ldots \ldots \ldots \ldots$

A.2 Building $3026-\mathrm{D}$-general status of facility $\ldots \ldots \ldots \ldots \ldots \ldots \ldots \ldots$ A-16

A.3 Building 3028 -general status of facility $\ldots \ldots \ldots \ldots \ldots \ldots \ldots \ldots \ldots$ A-20

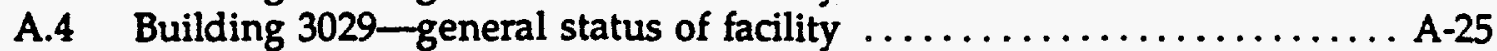

A.5 Building 3030 -general status of facility $\ldots \ldots \ldots \ldots \ldots \ldots \ldots \ldots \ldots$ A-32

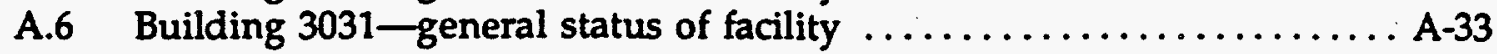

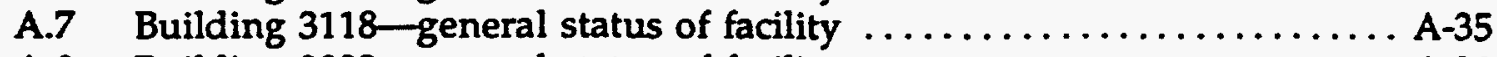

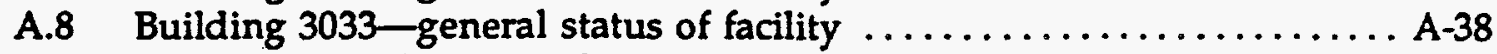

A.9 Building $3033-A-$ general status of facility $\ldots \ldots \ldots \ldots \ldots \ldots \ldots \ldots \ldots$

A.10 Building 3038 - general status of facility $\ldots \ldots \ldots \ldots \ldots \ldots \ldots \ldots \ldots \ldots \ldots$

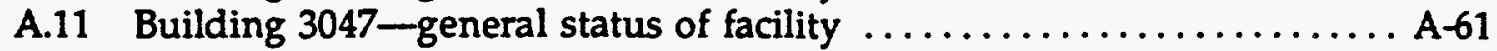

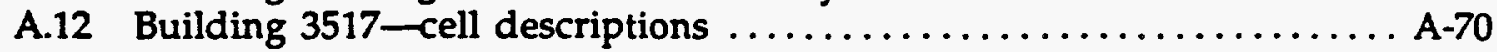

A.13 Building 3517 -general status of facility $\ldots \ldots \ldots \ldots \ldots \ldots \ldots \ldots \ldots$ A-74

A.14 Building 3517-estimated quantity of contaminated materials (excluding inventory) requiring removal/disposal ............. A-80

A.15 Building 7025-general status of facility $\ldots \ldots \ldots \ldots \ldots \ldots \ldots \ldots \ldots \ldots$

A.16 Actinide area of Building 9204-3-general status of facility . . . . . A A-86 



\section{ABBREVIATIONS}

\begin{tabular}{|c|c|}
\hline ADM & action description memorandum \\
\hline AHF & Alpha Handling Facility \\
\hline AR & Administrative Record \\
\hline CAT & collection and transfer system \\
\hline CRM & Center for Risk Management \\
\hline$\alpha$ & categorical exclusion \\
\hline D\&D & decontamination and decommissioning \\
\hline DMC & Document Management Center \\
\hline DOE & U.S. Department of Energy \\
\hline EA & environmental assessment \\
\hline EM-40 & $\begin{array}{l}\text { DOE Headquarters Office of Decontamination and } \\
\text { Decommissioning }\end{array}$ \\
\hline EM-60 & DOE Headquarters Office of Facility Transition and Management \\
\hline Energy Systems & Martin Marietta Energy Systems, Inc. \\
\hline EPA & U.S. Environmental Protection Agency \\
\hline ER & environmental restoration \\
\hline ES\&H & environment, safety, and health \\
\hline FDDM & Facility Disposition Decision Model \\
\hline FFA & Federal Facility Agreement \\
\hline FPDL & Fission Products Development Laboratory \\
\hline FSET & Facility Safety Evaluation Team \\
\hline HAZWOPER & hazardous waste operations and emergency response \\
\hline HEPA & high-efficiency particulate air \\
\hline $\mathrm{HQ}$ & DO̊E Headquarters \\
\hline HSD & hazards screening document \\
\hline HVAC & heating, ventilation, and air conditioning \\
\hline IFDP & Isotopes Facilities Deactivation Project \\
\hline IFSP & Isotopes Facilities Shutdown Program \\
\hline LCD & Limiting Conditions for Operations Document \\
\hline LLLW & liquid low-level (radioactive) waste \\
\hline SLLW & solid low-level (radioactive) waste \\
\hline NEPA & National Environmental Policy Act \\
\hline NRWTP & nonradiological wastewater treatment plant \\
\hline ORNL & Oak Ridge National Laboratory \\
\hline ORO & DOE Oak Ridge Operations Office \\
\hline ORR & operational readiness review \\
\hline OSR & operational safety requirement \\
\hline PSET & Plant Safety Evaluation Team \\
\hline PSS & problem safety summary \\
\hline PWTP & process waste treatment plant \\
\hline QA & quality assurance \\
\hline RAMSPAC & radioactive materials shipping and packaging \\
\hline $\mathrm{RL}$ & radioluminescent \\
\hline $\mathrm{RP}$ & radiation protection \\
\hline RTG & radio-thermoelectric generator \\
\hline RTS & Radiochemical Technology Section \\
\hline
\end{tabular}


S\&M

SA

SAR

SARUP

SSHASP

TRU

USQD

WBS

WESF surveillance and maintenance

safety assessment

safety analysis report

Safety Analysis Report Update Program

site-specific health and safety plan

transuranics

unreviewed safety question determination

work breakdown structure

Waste Encapsulation Storage Facility 


\section{EXECUTIVE SUMMARY}

The purpose of the Isotopes Facilities Deactivation Project (IFDP) is to place former isotopes production facilities at the Oak Ridge National Laboratory in a safe, stable, and environmentally sound condition; suitable for an extended period of minimum surveillance and maintenance (S\&M) and as quickly and economical as possible. Implementation and completion of the deactivation project will further reduce the risks to the environment and to public safety and health. Furthermore, completion of the project will result in significant S\&M cost savings in future years. The IFDP work plan defines the project schedule, the cost estimate, and the technical approach for the project. A companion document, the IFDP management plan, has been prepared to document the project objectives, define organizational relationships and responsibilities, and outline the management control systems to be employed in the management of the project. The project has adopted the strategy of deactivating the simple facilities first, to reduce the scope of the project and to gain experience before addressing more difficult facilities. A decision support system is being developed to identify the activities that best promote the project mission and result in the largest cost savings. This work plan will be reviewed and revised annually.

Deactivation of IFDP facilities was initiated in FY 1994 and will be completed in FY 1999. The schedule for deactivation of facilities is shown in Fig. ES-1. The total cost of the project is estimated to be $\$ 36 \mathrm{M}$. The costs are summarized in Table ES-1. Upon completion of deactivation, annual S\&M costs of these facilities will be reduced from the current level of $\$ 5 \mathrm{M}$ per year to less than $\$ 1 \mathrm{M}$ per year. 


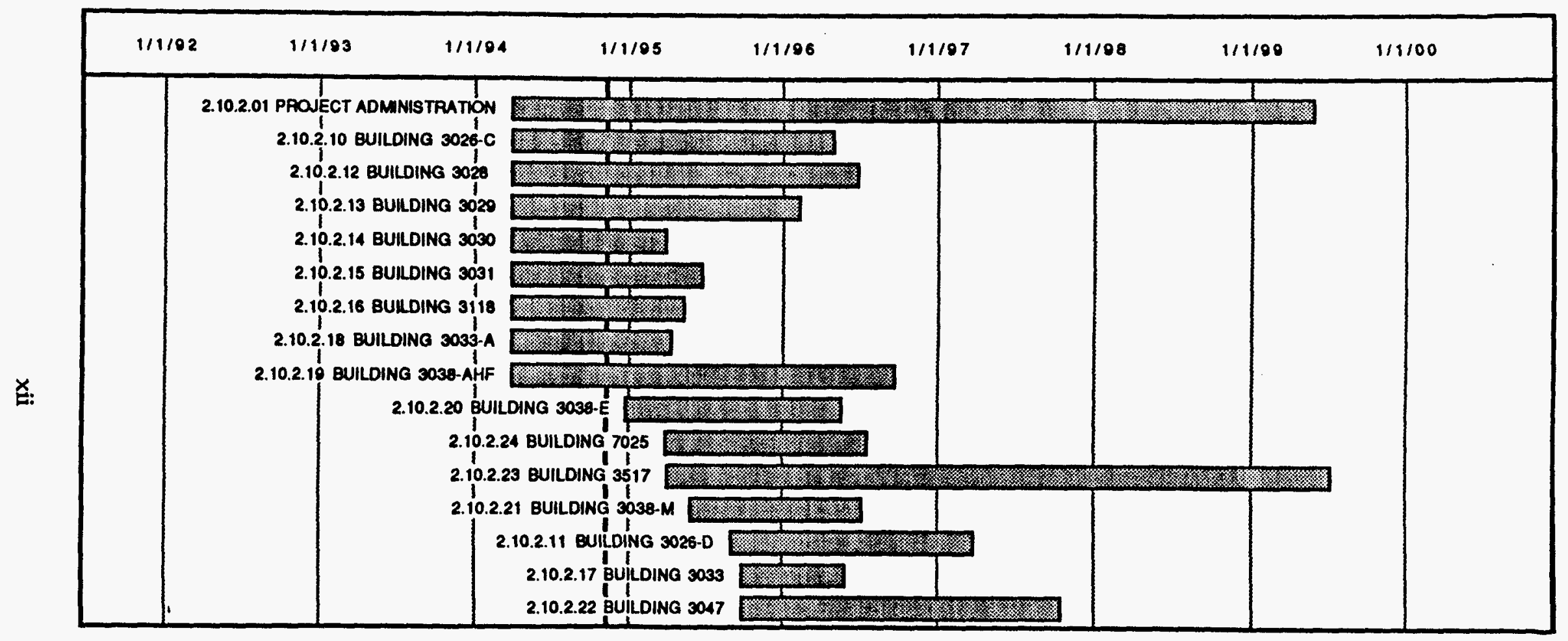

Fig. ES-1. Isotopes Facilities Deactivation Project schedule. 
Table ES-1. Isotopes Facilities Deactivation Project cost summary

\begin{tabular}{lccccccc}
\hline & FY 1995 & FY 1996 & FY 1997 & FY 1998 & FY 1999 & FY 2000 & TOTAL \\
\hline Project Management & 929 & 665 & 698 & 625 & 230 & 119 & 3266 \\
Surveillance and Maintenance & 4740 & 3941 & 2881 & 1911 & 1191 & 951 & 15615 \\
Deactivation & 3950 & 6073 & 4578 & 1572 & 702 & 0 & 26140 \\
TOTAL & 9619 & 10679 & 8157 & 4108 & 2123 & 1070 & 35756 \\
& & & & & & &
\end{tabular}




\section{INTRODUCTION}

\subsection{PURPOSE}

This work plan documents the objectives, technical requirements, and detailed work plans including schedules, milestones, and cost estimates. A companion document, the Isotopes Facilities Deactivation Project (IFDP) management plan, defines organizational relationships and responsibilities and outlines the management control systems to be used in the management of the project. This plan has been developed by the Environmental Restoration (ER) Program of Martin Marietta Energy Systems, Inc. (Energy Systems) for the U.S. Department of Energy (DOE) Oak Ridge Operations Office (ORO).

\subsection{SCOPE}

Sixteen facilities are currently in the IFDP, as listed in Table 1. A description of each facility is contained in Appendix A. To complete its mission, the IFDP must execute those activities required to deactivate and place each facility in shutdown condition. A deactivated shutdown facility is one in which (1) hazardous materials and waste and transferable radioactive contamination have been removed from accessible areas, (2) containment structures are in sound physical condition, (3) energy sources in the facility have been de-energized to the maximum extent practical, (4) use and occupancy of the building have been terminated, and (5) the facility is structurally sound and weathertight. The IFDP will identify all activities required to achieve these conditions in IFDP facilities and will manage their execution according to this plan. Existing building-specific procedures will be utilized and modified as required to conform to ER policy.

\subsection{MISSION}

The mission of the IFDP is to deactivate former Oak Ridge National Laboratory $(\mathrm{ORNL})$ isotopes production facilities. Specifically, the IFDP will

- place facilities into a safe, stable, inactive condition with the lowest practical surveillance and maintenance $(S \& M)$ costs while maintaining safety envelopes adequate to ensure the safety and health of the workers, the public, and the environment;

- establish a baseline S\&M program consistent with surplus and post-deactivation facility liabilities;

- ensure facility acceptance into the DOE Headquarters (HQ) Office of Decontamination and Decommissioning (D\&D) Program (EM-40); and

- minimize waste generation. 
Table 1. Scheduled shutdown facilities

Krypton-85 Enrichment Facility Metal Segmenting Facility

Alpha Powder Facility Source Development Laboratory Radioisotope Production Laboratory-C Radioisotope Production Laboratory-D Radioisotope Production Laboratory-H

Radioactive Gas Processing Facility

Radioactive Production Laboratory Annex Alpha Handling Facility Radioisotope Packaging and Shipping Facility Isotope Materials Laboratory Isotope Technology Building Fission Products Development Laboratory Tritium Target Preparation Facility Actinide Facility
Building 3026-C

Building 3026-D

Building 3028

Building 3029

Building 3030

Building 3031

Building 3118

Building 3033

Building 3033-A

Building 3038-AHF

Building 3038-M

Building 3038-E

Building 3047

Building 3517

Building 7025

Building 9204-3

-AHF - Alpha Handling Facility. 


\section{PROJECT OBJECTIVES AND APPROACH}

\subsection{PROJECT OBJECTIVES}

\subsubsection{Environment, Safety, and Health Objectives}

- Serve as a local and national model for DOE-HQ Office of Facility Transition and Management (EM-60) Environment, Safety, and Health (ES\&H) protection awareness and preparedness.

- Characterize the potential risks posed by IFDP facilities adequately to design deactivation and S\&M plans which effectively protect human ES\&H systems.

- Plan and implement deactivation activities to minimize worker, public, and ecological risk.

- Develop and implement an S\&M program and deactivation alternatives designed to place the IFDP facilities in a storage configuration that minimizes S\&M worker, public, and environmental risk for the present and future.

- Develop plans and establish systems to monitor known releases and to mitigate and document planned (discharges) and unplanned (spills) releases associated with deactivation and $S \& M$ activities.

- Seek opportunities to develop and apply innovative technologies (e.g., remote and robotics systems) to further reduce potential worker exposure to hazards and further reduce S\&M and deactivation costs.

\subsubsection{Compliance Objectives}

- Serve as a model project with respect to the identification of, and compliance with, requirements, orders, and guidelines applicable to EM-60 deactivation and S\&M activities.

- Identify the DOE Orders and guidelines, state requirements, U.S. Environmental Protection Agency (EPA) requirements, other federal requirements, and ER Program and Energy Systems project requirements that are applicable to deactivation and S\&M plans and actions.

- Identify and follow EM-60 deactivation project pathways that reduce downstream $S \& M$ compliance activities, costs, and liabilities.

- Design project and quality assurance (QA) plans to enable all deactivation activities to comply with applicable and relevant requirements.

- Review facility health and safety compliance strategies appropriate for EM-60 rather than operating facilities. 


\subsubsection{EM-60/EM-40 Transition Objectives}

- Serve as a model EM-60 project, with respect to the development, negotiation, and implementation of EM-60/EM-40 transition criteria and agreements that are consistent with DOE-HQ and DOE-ORO guidance.

- Identify the minimum set of deactivation activities that must be completed for each facility to transition, and a process for identifying additional transition activities that could reduce life cycle cost using cost and risk decision criteria and rules.

- Establish and maintain a formal system for planning, estimating, scheduling, and accomplishing EM-60/EM-40 facility transition actions.

\subsubsection{Waste Management Objectives}

- Incorporate secondary waste stream minimization into deactivation and S\&M plans.

- Implement deactivation alternatives that maximize waste segregation and recycling opportunities, while minimizing life cycle waste management costs.

- Provide a platform for developing and applying new systems and technologies for technically sound and cost-efficient waste treatment, storage, and disposal.

- Develop and implement project approaches and plans designed to minimize waste handling and packaging requirements.

- Develop estimates and projections regarding the nature and magnitude of wastes expected from deactivation and S\&M activities to support Waste Management Program planning and to use in deactivation program planning.

- Maximize acceptance of IFDP waste by private industry through generating waste streams that meet applicable industry waste acceptance criteria.

\subsubsection{Life Cycle Cost and Risk Objectives}

- Serve as a national model for the development and implementation of project plans designed to reduce life cycle facility deactivation, decontamination, compliance, and S\&M costs, risks, and liabilities.

- Develop and apply the Facility Disposition Decision Model (FDDM) to provide a defensible basis for decisions regarding when, how, and to what extent to deactivate surplus federal facilities.

- Evaluate risk and cost trade-offs among alternative IFDP project pathways to identify the deactivation, decontamination, and S\&M pathways that minimize life cycle costs and risks. 
- Utilize the FDDM to integrate stakeholder, management, and technical considerations into a common decision framework.

- Enhance the Work Breakdown Structure (WBS) on an interactive basis to incorporate the results of the FDDM life cycle cost and risk application.

\subsection{PROJECT APPROACH/STRATEGY}

The basic mission of the IFDP is to place former isotopes production facilities into a safe, stable, and deactivated state with the lowest possible S\&M cost while maintaining safety envelopes adequate to protect the safety and health of the workers, the public, and the environment and to complete the turnover of all facilities to the ORNL D\&D Program. Technical requirements define the project's completion and the acceptable conditions for turnover to the ORNL D\&D Program.

The technical requirements defined in this edition ( $\operatorname{Rev} 0)$ of the IFDP Work Plan, represent the best technical judgement of engineers and technicians experienced in the past operations and knowledgeable of the current conditions of these facilities. The FDDM (see section 2.1 .5 ) is being developed and will be available in FY 1995 and will be used to augment the list of deactivation tasks. The FDDM will be an analytic tools that can quantitatively measures the risk reduction and life cycle cost benefit associated with each deactivation task. Results from the FDDM will be reflected in subsequent revisions of this work plan.

\subsubsection{General Technical Requirements}

General technical requirements define the IFDP's overall approach to fulfilling the end-state condition required for turnover to the ORNL D\&D Program. Applicable requirements set forth in the draft DOE Policy Memorandum for Acceptance of Facilities for ER Program, issued March 15, 1991, by L. F. Duffy, will be met.

The IFDP shall ensure that imminent hazards to personnel or the environment are controlled through partial closure, removal, isolation, mitigation, or stabilization. The IFDP shall also ensure that structures can be maintained in a safe condition, with removal of immediate threats to human health and safety or implementation of appropriate compensatory measures (barriers, access controls, administrative controls, etc.).

The IFDP's end state shall result in the classification of IFDP facilities as nonoccupied facilities. As such, compliance with DOE Order 6430.1A, General Design Criteria, is not required. IFDP activities shall ensure that access during the surveillance phase is not required at a greater frequency than necessary to maintain the nonoccupied facility status. 
The IFDP will end with IFDP facilities being turned over to the ORNL D\&D Program for basic S\&M, and eventual D\&D. Existing ORNL ER Program systems shall be used for the project's execution, except as provided in this project work plan and the project management plan.

\subsubsection{Configuration Requirements}

The configuration of IFDP facilities shall be modified and controlled sufficiently to ensure safety and regulatory compliance during project performance and postproject S\&M. As the minimum configuration control requirement, records shall be established and archived for essential systems for postproject S\&M and provide meaningful D\&D planning. As a minimum, the following records should be established and maintained:

- a description of each facility and a summary of its history and past use;

- final radiological status surveys;

- logbook files, equipment operating procedures, S\&M requirements, procedures, records, drawings, photographs, etc., that reflect "as-left" configuration;

- zero energy-check records for electrical circuits that were de-energized;

- installed piping system and equipment blank records;

- facility hazards screening documents (HSDs) and related facility safety documentation;

- radiological posting in compliance with applicable requirements set forth in the ORNL Health Physics Manual and the DOE Radiological Control Manual;

- pending radiation occurrence reports, event fact sheets, unusual occurrence reports, and/or any other out-of-standard condition reports finalized and closed out;

- documentation demonstrating compliance with worker safety and health requirements;

- any required permits relating to the facility's current or anticipated use (Activities shall not preclude subsequent closure options until permitting dictates final closure.); and

- deactivation check sheets completed and approved by the responsible personnel performing the actual work, the overview organizations, and plant management.

\subsubsection{Hazardous and Radioactive Materials Removal/Stabilization Requirements}

Hazardous and radioactive materials shall be removed from the facilities or stabilized/fixed sufficiently to ensure long-term safety and regulatory compliance of IFDP facilities, enable plant classification as a nonoccupied facility, and enable subsequent successful D\&D.

Materials shall be removed and/or stabilized sufficiently to ensure that the facilities comply with the ORNL Radiological Control Manual, as applicable to a nonoccupied facility after completion of deactivation. As a general guide, "as-left" contamination and radiation levels should be no greater than the levels encountered during normal operation and occupancy of the facilities. 
To ensure long-term safety and regulatory compliance, the following requirements apply.

- Permanent radiation areas to be entered for surveillance shall be decontaminated and released or the surface contamination fixed or stabilized to preclude resuspension and/or migration of loose contamination. Temporary radiation areas inside and outside of buildings shall be eliminated.

- Packaged radioactive and mixed waste with identified final disposition shall be removed and disposed of.

- All hazardous materials shall be removed.

- Accessible interior glove box surfaces shall be decontaminated or the surface contamination stabilized. Openings to glove boxes shall be sealed in a manner that ensures confinement of remaining contamination.

- Loose or damaged (friable) asbestos in areas expected to be entered during surveillance shall be removed or stabilized.

- Tanks, vessels, and pipes shall be drained using installed equipment and features. Heels shall not contain material classified as hazardous waste.

- Hazardous materials used for deactivation and cleanup work shall be collected and disposed of.

- Emergency lighting and associated batteries from the facilities shall be removed and disposed of.

To ensure minimum life cycle cost, the following requirements apply.

- The remaining surplus materials, fumiture, equipment, supplies, and spare parts should be inventoried, labeled, segregated, and transferred to other facilities for use or disposed of as waste.

- Disposal of waste materials will be maximized during deactivation.

- Existing system and equipment capabilities will be used for material removal/stabilization to the maximum extent possible.

- Operations and inventories that require implementation of operational safety requirements (OSRs) during the surveillance period will be eliminated.

\subsubsection{Surveillance and Maintenance Requirements}

Facility configuration shall ensure that $D \& D$ options are not foreclosed and that facility safety and environmental protection can be maintained until $D \& D$. 
To ensure safety and environmental protection during surveillance, the following requirements apply.

- Consistent with ORNL Plant Safety Basis, the operation of safety and utility systems shall be reduced to the lowest extent possible, while maintaining ventilation, alarms, and other capabilities necessary for a deactivated facility. Required vital safety systems and utility systems shall be fully functional and have operating procedures in place.

- To minimize points of ingress, doors to the facilities shall be locked from the inside except those required for entrance by surveillance crews.

- Security systems and procedures shall be adequate to prevent unauthorized entry to facilities.

- Liquid effluent sources from facilities shall be eliminated prior to the transfer to D\&D. Flow routes to disposal sites will be isolated. Isolation will be achieved by sealing or turning off valves at supply points and screening off accessible outlets of the discharge pipes for varmint control.

- Facility penetrations (louvers, pipe openings, etc.) will be closed off where practical to prevent intrusions by birds and other animals.

- Systems that were opened to facilitate deactivation and could present a radiological and/or an industrial safety problem, if left open, shall be adequately closed off.

- Known facility roof leaks and/or deteriorated roof panels shall be repaired.

- Radiation space monitoring and continuous air monitoring systems shall be reduced to a level commensurate with the surveillance requirements. As a general guide, "as-left" contamination and radiation levels in the plants should be low enough that only portable monitoring equipment is required during surveillance entries.

To achieve a nonoccupied facility status, the following requirements apply.

- Ventilation and monitoring equipment shall be eliminated or consolidated, relocated, housed, operated, and/or maintained such that facility entry frequency does not compromise the nonoccupancy status.

- Fire protection systems shall be modified or eliminated to both achieve and reflect the nonoccupied status and to minimize system testing and maintenance.

- Electrical and water supply services to the process buildings shall be isolated; electrical and water supply services in the surrounding yard areas shall be reduced to meet minimum surveillance support requirements. 
- The building steam system shall be deactivated wherever practical. If not practical to deactivate the system, it shall be inspected and upgraded to ensure a 10-year operating life.

\subsection{FACILITY DEACTIVATION PROCESS}

The process of deactivating IFDP facilities is illustrated in Fig. 1. The figure indicates the general sequence of the deactivation process; however, some steps (i.e., waste disposal) are performed in parallel with other steps or are continuous throughout the deactivation process. The exact deactivation sequence is actually determined on a facility-specific basis. The following lists the specific goals to be accomplished in completing each step shown in Fig. 1.

1. Characterize facility conditions:

- update radiological surveys,

- assess facility conditions,

- inventory hazardous chemical inventory,

- inventory radioactive materials in facility, and

- baseline current S\&M activities.

This activity is required to assess existing ES\&H risks associated with a facility and to baseline exist S\&M costs.

2 Prioritize deactivation activities (procedures):

- evaluate for liability reducing activities,

- assess based upon worker risk,

- establish deactivation end-point criteria, and

- finalize evaluation utilizing EM-40 acceptance criteria.

Based upon the information obtained in step 1, activities will be identified that will reduce ES\&H risks and S\&M costs. These will be prioritized according to risk reduction and cost savings.

3. Remove inventory:

- radioactive materials, and

- hazardous chemicals, except those needed for decon tasks.

This step is required to meet EM-40 acceptance criteria. This reduces the hazards classification of a facility and allows a reduction in facility safety documentation. It will also reduce the $S \& M$ costs associated with maintaining an inventory list. 


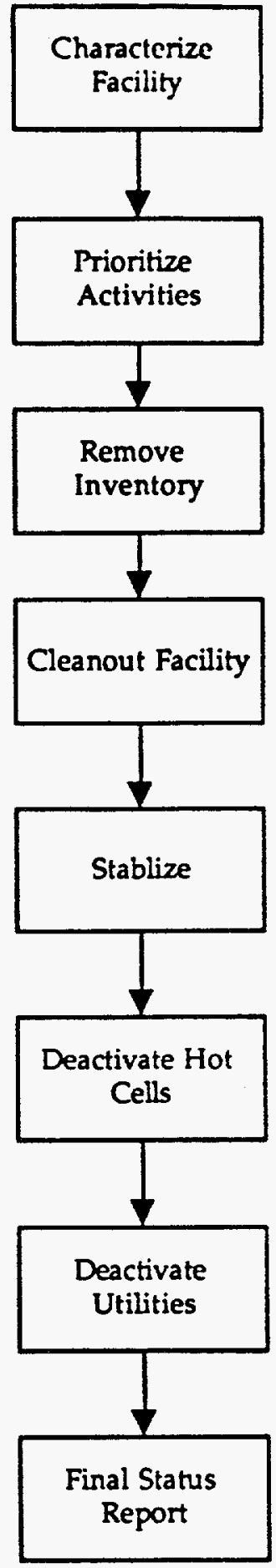

Fig. 1. Deactivation process for surplus facilities. 


\section{Clean out facility:}

- remove surplus equipment,

- remove loose unanchored equipment from hot cells, hoods, and glove boxes,

- remove abandoned equipment from operating areas, and

- characterize, package, and remove all wastes.

This step will salvage usable equipment and is a good housekeeping practice. Abandoned equipment such as old office furniture, storage cabinets, etc. will be removed. Neat orderly facilities draw far less attention from auditors. This also eliminates combustible materials from facilities which, in some cases, will reduce fire protection requirements.

\section{Stabilize facility:}

- remove transferrable contamination from secondary containment,

- bond and label fixed contamination,

- repair deficiencies in primary containment systems,

- remove potential airbome contamination from hoods and glove boxes,

- deactivate all services to hoods and glove boxes and seal drains, and

- repair roofs.

A structurally sound facility is required by the EM-40 facility acceptance criteria. Removal of contamination will reduce hazards to $S \& M$ personnel, reduce background levels, ensuring longer life for seals and glove boxes, reduce the frequency of filter changes, and minimize the potential for a release to the environment. Since drains will be plugged, all sources of liquids must be eliminated and thus, all services to hoods and glove boxes must be taken out of service.

\section{Deactivate hot cells:}

- flush cells to reduce gross levels of potential airborne contamination,

- terminate all fluid penetration into cells,

- deactivate all electrical service to the cells,

- plug all drains, and

- seal and lock all access ports.

Deactivation of hot cells will decrease future S\&M costs. This will allow removal of monitrons and continuous air monitors from facilities. The service life of manipulator boot and in-cell filters will be extended. Plugging of all drains is required by the Federal Facility Agreement (FFA). With all drains being plugged it is essential that all possible pathways for introduction of liquids into cells be eliminated and thus all penetrations and access ports must be sealed. 
7. Deactivate utilities in facilities:

- deactivate all electrical circuits except those used for monitoring systems,

- deactivate and drain all piping, and

- remove all unnecessary instrumentation.

This eliminates utility costs and future maintenance of these systems.

8. Prepare Final Facility Status Report:

- document facility history,

- document "as-left" condition, and

- develop procedures for post-deactivation S\&M and for unplanned entries.

The EM-40 acceptance criteria requires that the facility conditions be documented at the time of turnover. Procedures for S\&M are required by DOE Orders on Conduct of Operations.

\subsubsection{Deactivation Activities}

The following is a description of activities to be performed in IFDP facilities to complete deactivation and achieve a configuration requiring minimal S\&M. These activities are required to reduce facility S\&M costs and/or mitigate ES\&H vulnerabilities. The first six of the activities are generic (i.e., deactivate hot cell) in that the same basic activity will be repeated in several facilities. This is followed by a description of activities for each facility. In the following section, the term clean is the process of removing debris followed by a wipe down of surfaces to remove loose contamination.

\subsubsection{Deactivate hot cell}

Most IFDP facilities include one or more hot cells. The activities required to deactivate a hot cell are generic in nature but will vary considerably in intensity and duration depending upon the condition of the individual hot cell. The following are the general steps to be taken; however, the sequence will vary on a case-by-case basis.

- Remove all waste and loose equipment from hot cell.

- Perform general wash down to remove potential airborne contamination.

- Stabilize primary containment (i.e., seal-leaking, oil-filled windows).

- Identify, label, and plug all service lines to the cell.

- Replace manipulator boots and in-cell filters.

- Plug all drains. 
- Document final radiological condition of the cell.

- Secure all access to cell interior.

- Relocate differential pressure indicators so they can be viewed without entering the facility.

The final condition of the cell will be such that there is a minimal chance for a release to the building and the only periodic inspection of the cell is a weekly check of the differential pressure, which can be performed without entering the facility. No planned maintenance would be required in the 10 -year interval before $D \& D$. It should be noted that the manipulator will remain in the cell because this is the least expensive way to seal the manipulator ports and to minimize waste generation during deactivation.

\subsubsection{Deactivate glove boxes}

Glove boxes will be deactivated. For small glove boxes (ones that can fit into a B-25 waste container), all service will be disconnected and the box filled with waste, sealed, loaded into a B-25 container, and disposed of as solid low-level (radioactive) waste (SLLW). The box will then be packaged and disposed of as waste. Large glove boxes will be cleaned to remove all transferable contamination from its interior, painted to bond any fixed contamination, and all ports sealed. All service piping will be disconnected and sealed. All drains will be disconnected and sealed. Differential pressure indicators will be relocated so they can be viewed without entering the facility.

\subsubsection{Deactivate hoods}

All high-velocity, air-flow hoods will be wiped down to remove transferrable contamination, liquid low-level (radioactive) waste (LLLW) drains are to be plugged, and the hood locked and tagged out-of-service. All utility services to hoods remaining in place will be disconnected.

\subsubsection{Piping, utility, and alarm deactivation}

All water, air, steam (if practical), and gas piping will be disconnected at the supply header coming to the facility. All lines will be drained. All electrical service not essential to the basic S\&M requirements of the deactivated facility will be disconnected at the main breaker box. All radiation protection (RP) instruments and alarms will be removed. Remote air sampling capability will be installed wherever possible to minimize future entries into the facility.

\subsubsection{Fire protection}

Fire protection systems can be converted to dry or the buildings must be heated to maintain minimum temperatures above $40^{\circ} \mathrm{F}$. This is being evaluated on a facilityspecific basis. The results of this evaluation will be reflected in the next revision to this work plan. 


\subsubsection{Final facility status report}

A final report will be prepared which will document the history of the building and the physical and radiological condition of the facilities, provide as-is drawings of essential facility support systems, and provide S\&M requirements and procedures.

\subsubsection{Facility-Specific Deactivation Work Plan Activities}

\subsubsection{Building 3026-C}

Building 3026 is a large $\left(14,000 \mathrm{ft}^{2}\right)$ wood frame structure with no secondary containment. The building is divided into two facilities, 3026-C (west half of the building) and 3026-D (east end). Building 3026-C contains four manipulator hot cells, four process hot cells, and several laboratories with high air-flow hoods. Deactivation of this facility will include the following activities.

- Repackage radioluminescent (RL) lights. Numerous ${ }^{3} \mathrm{H}$-filled RL lights are to be inventoried, disassembled as needed, and placed in Type A packages suitable for transfer off-site.

- Dispose of cylinders. Numerous gas cylinders used in the ${ }^{85} \mathrm{Kr}$ program remain at ORNL. These are to be vented in accordance with allowable release limits, valve assemblies dismantled, and packaged as waste.

- Residual ${ }^{3} \mathrm{H}$ contamination is to be removed from Labs 7 and 16.

- Deactivate ${ }^{85} \mathrm{Kr}$ Columns 1 through 4. This activity involves the following: (1) deactivate all services to the ${ }^{85} \mathrm{Kr}$ thermal diffusion columns; (2) deactivate cooling tower servicing columns; (3) dispose of ${ }^{85} \mathrm{Kr}$ contaminated waste; (4) decontaminate all storage tanks; (5) remove all pumps from storage system and package for disposal as waste; and (6) deactivate all services to storage system.

- Deactivate the chilled water system. The chilled water system is to be drained, pipes and electrical service disconnected, and the compressor salvaged.

- Deactivate hot cells. In addition to the activities described in Sect. 2.3.1.1, $\mathrm{Zn-Br}$ filled shield windows are to be drained and the $\mathrm{Zn}-\mathrm{Br}$ disposed of as waste.

- Deactivate the piping, utilities, and alarms as described in Sect. 2.3.1.4.

- Disconnect ductwork. The ductwork that ventilates Labs 7 and 16 from the central plant ventilation system is to be disconnected and blanked.

- Prepare final facility status report as described in Sect. 2.3.1.6.

- Provide fire protection. This building is of wood frame construction and must be protected by an automated sprinkler system. The options are to upgrade the building heating system and keep the existing wet sprinkler system or to replace the existing system with a dry system and deactivate the building's steam heating 
system. A detailed cost comparison has shown that it is more cost effective to maintain the existing system.

\subsubsection{Building 3026-D}

Building 3026-D contains six manipulator hot cells currently used to store steel specimens remaining from metallurgical testing. The estimated $4000 \mathrm{lb}$ of specimens are irradiated and contain approximately $300 \mathrm{Ci}$ of ${ }^{60} \mathrm{Co}$. Deactivation of this facility will include the following activities.

- Deactivate hot cells. In addition to the activities described in Sect. 2.3.1.1, the irradiated metal specimens are to be removed from the hot cells and transferred to other ORNL facilities. The $\mathrm{Zn}$-Br-filled shield windows are to be drained and the $\mathrm{Zn}-\mathrm{Br}$ disposed of as waste.

- Deactivate piping, utilities, and alarms as described in Sect. 2.3.1.4.

- Prepare final facility status report as described in Sect. 2.3.1.6.

- Provide fire protection. This building is of wood frame construction and must be protected by an automated sprinkler system. The options are to upgrade the building heating system and keep the existing wet sprinkler system or to replace the existing system with a dry system and deactivate the building's steam heating system. Preliminary indications are that the former is more cost effective, but a more detailed cost comparison is being prepared to confirm this conclusion.

\subsubsection{Building 3028}

Building 3028 is a three-story, steel-frame structure covered by metal siding and has a total floor area of approximately $4000 \mathrm{ft}^{2}$. The facility contains seven hot cells used primarily for the alpha powder [transuranics (TRU) isotopes in powder form] operations. All inventory has been removed, but six of the seven cells remain highly contaminated. Large areas of alpha contamination exist in the secondary containment area behind Cells 1 through 5 . Deactivation of this facility will include the following activities.

- Deactivate cells. In addition to the activities described in Sect. 2.3.1.1, the waterfilled shielding tanks in front of Cells 1 through 5 will be drained. The chilled water system associated with these tanks will be deactivated. The charging area behind Cells 1 through 5 will be cleaned to remove potential airborne contamination.

- Deactivate piping, utilities, and alarms as described in Sect. 2.3.1.4.

- Prepare final facility status report as described in Sect. 2.3.1.6.

- Provide fire protection. The building has an automated wet sprinkler system and could be converted to a dry system. The heating system must keep the minimum building temperature above $40^{\circ} \mathrm{F}$. The building's steam heating system is very 
old, and steam leaks are a continuous problem; therefore, new heaters and steam lines would have to be installed if the conversion to a dry system is not made. A detailed cost comparison of the two options has shown that it is more cost effective to convert the existing automated wet sprinkler system to a manually activated dry sprinkler system and deactivate the building's steam heating sytem.

\subsubsection{Building 3029}

Building 3029 is a single-story, steel-frame structure covered by corrugated metal siding with a total floor area of approximately $3000 \mathrm{ft}^{2}$. The facility contains four manipulator hot cells and four glove boxes. The charging area behind Cell 3 is contaminated with ${ }^{13} \mathrm{Cs}$ from a spill during production operations. Deactivation of this facility will include the following activities.

- Deactivate cells as described in Sect. 2.3.1.1.

- Deactivate piping, utilities, and alarms as described in Sect. 2.3.1.4.

- Clean up ${ }^{137} \mathrm{Cs} .{ }^{137} \mathrm{Cs}$ contamination behind the cells must be cleaned up and lead shielding cleaned and removed.

- Deactivate glove boxes. The two ${ }^{131}$ I glove boxes will be cleaned and sealed and left in the building. The ${ }^{14} \mathrm{C}$ and ${ }^{\circ} \mathrm{Tc}$ glove boxes will be removed and managed as SLLW.

- Prepare final facility status report as described in Sect. 2.3.1.6.

- Provide fire protection. Cost estimates have demonstrated that it is less expensive to convert to a manually activated dry system and deactivate the building's steam heating system.

\subsubsection{Buildings 3030,3118 , and 3031}

Buildings 3030 and 3031 were built as separate buildings. Building 3118 was constructed to enclose the area between the two facilities and to cover the access doors to the cells in the buildings; it has a floor area of $900 \mathrm{ft}^{2}$. Buildings 3030 and 3031 each contain a hot cell, a hood, and have a floor area of $825 \mathrm{ft}^{2}$. Building 3118 was used primarily as a storage shed and has areas of contamination on the floor. Deactivation of this facility will include the following activities.

- Deactivate cells as described in Sect. 2.3.1.1.

- Deactivate piping, utilities, and alarms as described in Sect. 2.3.1.4.

- Deactivate hoods as described in Sect. 2.3.1.3.

- Replace roof. The built-up roof on the complex comprising Buildings 3030,3118 , and 3031 leaks and will be replaced. 
- Prepare final facility status report as described in Sect. 2.3.1.6.

- Provide fire protection. These facilities utilize a dry sprinkler system, and no conversion is needed.

- Clean floors. The floors will be cleaned to remove transferable contamination.

\subsubsection{Building 3033}

Building 3033 is a steel-frame structure covered with aluminum siding and has a floor area of $1200 \mathrm{ft}^{2}$. The facility houses two separate radioisotopes processing systems for handling gaseous ${ }^{3} \mathrm{H}$ and ${ }^{25} \mathrm{Kr}$. Deactivation of this facility will include the following activities.

- Deactivate ${ }^{3} \mathrm{H}$ system. The ${ }^{3} \mathrm{H}$ will be removed from the ${ }^{3} \mathrm{H}$ traps, and the ${ }^{3} \mathrm{H}$ processing system will be disassembled and packaged for disposal. The ${ }^{3} \mathrm{H}$ processing hood will be decontaminated, and all hood support systems will be labeled and deactivated.

- Deactivate ${ }^{85} \mathrm{Kr}$ purification system. The charcoal traps and roughing pumps from the ${ }^{2} \mathrm{Kr}$ processing system will be removed, packaged, and disposed of as waste.

- Deactivate piping, utilities, and alarms as described in Sect. 2.3.1.4.

- Prepare final facility status report as described in Sect. 2.3.1.6.

- Provide fire protection. These facilities utilize a dry sprinkler system, and no conversion is needed.

\subsubsection{Building 3033-A}

Building 3033-A is a steel-frame structure covered with aluminum siding and has a floor area of $242 \mathrm{ft}^{2}$. The building was used only for low-level, radioactive operations in a glove box and a hood. The glove box was removed several years ago. Deactivation of this facility will include the following activities.

- Deactivate piping, utilities, and alarms as described in Sect. 2.3.1.4.

- Deactivate hood as described in Sect. 2.3.1.3.

- Repair roof. The roof on the building leaks and will be patched.

- Prepare final facility status report as described in Sect. 2.3.1.6.

- Provide fire protection. These facilities utilize a dry sprinkler system, and no conversion is needed. 


\subsubsection{Building 3038-Alpha Handling Facility}

Building 3038 is a masonry structure with a total floor area of $7250 \mathrm{ft}^{2}$. It is divided by concrete block walls into three separate facilities: Building 3038-E, 3038- $\mathrm{M}$, and 3038-Alpha Handling Facility (AHF). The 3038-AHF contains five hot cells in one operating area and seven glove boxes in an adjacent room. The operating area is contaminated with alpha contamination. Deactivation of this facility will include the following activities.

- Deactivate cells. In addition to the activities described in Sect. 2.3.1.1, the waterfilled, shielding tanks in front of the hot cells will be drained. The chilled water system associated with these tanks will be deactivated. The operating area in front of the hot cells will be cleaned to remove potential airborne contamination.

- Deactivate glove boxes. The seven glove boxes in the facility will be disposed of as described in Sect. 2.3.1.2.

- Deactivate piping, utilities, and alarms as described in Sect. 2.3.1.4.

- Prepare final facility status report as described in Sect. 2.3.1.6.

- Provide fire protection. Cost estimates have demonstrated that it is less expensive to convert to a manually activated dry system and deactivate the building's steam heating system.

\subsubsection{Building 3038-E}

Building 3038-E contains eight hoods, ten glove boxes, and one manipulator hot cell in three connected rooms. The hoods and glove boxes contain transferable uranium and TRU isotopes contamination. Deactivation of this facility will include the following activities.

- Deactivate cell. The yttrium hot cell will be deactivated as described in Sect. 2.3.1.1.

- Deactivate glove boxes. The eleven glove boxes in the facility will be disposed of as described in Sect. 2.3.1.2. The rolling mill box in the north lab and the two inert glove boxes in the south lab will remain in the facility as their size would require them to be cut up to be removed from the building.

- Deactivate piping, utilities, and alarms as described in Sect. 2.3.1.4.

- Prepare final facility status report as described in Sect. 2.3.1.6.

- Deactivate hood as described in Sect. 2.3.1.3.

- Provide fire protection. Cost estimates have demonstrated that it is less expensive to convert to a manually activated dry system and deactivate the building's steam heating system. 


\subsubsection{Building 3038-M}

The 3038-M facility is a $1300-\mathrm{ft}^{2}$ area in the center of Building 3038 . ORNL's Radioactive Materials Shipping and Packaging (RAMSPAC) operations are currently located in this area. The area has a barricade behind which radioisotopes in liquid form were handled and packaged. The barricade consists of a shadow-shield wall that is open at the top. Confinement of radioactive materials is provided by continuous airflow over the wall. All inventory has been removed from the barricade area, but the area behind the wall is highly contaminated with a variety of radioisotopes. Deactivation of this facility will include the following activities.

- Deactivate barricade. All waste from the barricade area will be removed. The barricade area will be cleaned, and all service lines to it will be deactivated. Access to the barricade will be secured.

- Deactivate piping, utilities, and alarms as described in Sect. 2.3.1.4.

- Prepare final facility status report as described in Sect. 2.3.1.6.

- Provide fire protection. Cost estimates have demonstrated that it is less expensive to convert to a manually activated dry system and deactivate the building's steam heating system.

\subsubsection{Building 3047}

Building 3047 is a three-story, steel-frame building with concrete block exterior and interior walls. Building 3047 is structurally linked to Building 3047-A (an office building) but since they have separate ventilation systems, the buildings are considered separate. Building 3047-A is not in the IFDP. Building 3047 houses four high-level, beta-gamma hot cells, one alpha handling hot cell, seven laboratories for handling low-level materials, two glove boxes, and a decontamination room. Deactivation of this facility will include the following activities.

- Deactivate chilled water system. The chilled water system (air conditioning) will be drained, pipes and electrical services disconnected, and the pumps salvaged.

- Deactivate glove boxes. The gadolinium press box and the ${ }^{14} \mathrm{C}$ glove boxes in the facility will be disposed of as described in Sect. 2.3.1.2.

- Deactivate hoods. The hoods in Rooms 105, 109, 208, 209, and 210 will be deactivated as described in Sect. 23.1.3

- Clean up vacuum pit. Vacuum system's surge tank will be decontaminated.

- Clean up filter house. Pieces of contaminated, high-efficiency particulate air filter media that are lodged on the control damper to the filter house in the west airlock will be removed. 
- Deactivate hot cells. Hot Cells A, B, C, D, and the alpha cell in Room 110 will be deactivated as described Sect. in 2.3.1.1. In addition, the hot cell entry box in Room 110 will have water-shielding tanks drained and the box cleaned and disposed of. The sump sludge under Cell $D$ will be removed.

- Deactivate piping, utilities, and alarms as described in Sect. 2.3.1.4.

- Prepare final facility status report as described in Sect. 2.3.1.6.

- Provide fire protection. Cost estimates have demonstrated that it is less expensive to convert to a manually activated dry system and deactivate the building's steam heating system.

\subsubsection{Building 3517}

Building 3517 is a three-story, braced, steel-frame structure with metal deck roofs and 12-in. nonreinforced concrete masonry walls on the lower two stories. The building has a total floor area of approximately $18,000 \mathrm{ft}^{2}$. The facility contains eight manipulator hot cells and 16 process cells. The facility currently stores the IFDP inventory of surplus radioisotopes, which primarily consist of approximately $150,000 \mathrm{Ci}$ of ${ }^{137} \mathrm{Cs}$ and $100,000 \mathrm{Ci}$ of ${ }^{0 \mathrm{Sr}}$. This material is to be repackaged to meet waste acceptance criteria to be issued by the Waste Encapsulation Storage Facility (WESF), located in Richland, Washington, and shipped to this facility. Small quantities of Co, Eu, Gd are also stored in the building. Approximately $450 \mathrm{~g}$ of $24 \mathrm{Cm}$ belonging to the Transuranium Production Program is also stored in the building. Four radio-thermoelectric generators (RTGs), which contain in excess of $1,000,000 \mathrm{Ci}$ of ${ }^{\circ} \mathrm{Sr}$, are stored next to the facility but are not the responsibility of the IFDP. Three of the RTGs are in the ORNL D\&D Program, and the fourth (the BUP-500) is an orphan with its final disposition yet to be determined. Deactivation of this facility will include the following activities.

- Justify resumption of limited repackaging operations. Upon receiving waste acceptance criteria from WESF, determine the repackaging requirements and the extent of process operation that must be resumed to perform repackaging operations. Once the requirements are established, the options of using Building 3517 or some other ORNL facility will be evaluated. If the use of Building 3517 proves to be the best option, a justification for resumption of repackaging operations will be prepared.

- Upgrade facility. After the needs are evaluated, all necessary physical upgrades to the facility required to resume source repackaging operations will be performed.

- Perform Operational Readiness Review (ORR). An ORR will be performed in support of the resumption of repackaging operations.

- Transfer ${ }^{24} \mathrm{Cm}$. Seventeen containers of ${ }^{24} \mathrm{Cm}$ will be transferred to the Chemical Engineering Development Center at ORNL. 
- Package Co, Eu, Gd for retrievable storage. Surplus Co, Eu, and Gd material will be repackaged for retrievable storage and transferred to the solid waste storage area.

- Repackage ${ }^{137} \mathrm{Cs}$. All ${ }^{137} \mathrm{Cs}$ sources will be repackaged to meet WESF criteria and transferred to WESF.

- Repackage ${ }^{\circ} \mathrm{Sr}$. All ${ }^{\circ} \mathrm{Sr}$ sources will be repackaged to meet WESF criteria and transferred to WESF.

- Deactivate hot cells. Manipulator Hot Cells 10,11,12,13,14, 15, 16, and 18 will be deactivated as described in Sect. 2.3.1.1.

- Deactivate piping, utilities, and alarms as described in Sect. 23.1.4.

- Prepare final facility status report as described in Sect. 2.3.1.6.

- Provide fire protection. Cost estimates have demonstrated that it is less expensive to convert to a manually activated dry system and deactivate the building's steam heating system.

\subsubsection{Building 7025}

Building 7025 is a prefabricated, metal-sided building with a total floor area of $590 \mathrm{ft}^{2}$. The building contains a large $\left(26 \mathrm{ft}\right.$ long) stainless steel hood that houses a ${ }^{3} \mathrm{H}$ target fabrication system. The facility also houses a hood in which a thin film evaporator was once installed. Deactivation of this facility will include the following activities.

- Deactivate ${ }^{3} \mathrm{H}$ system. The ${ }^{3} \mathrm{H}$ Target Fabrication Facility hood will be deactivated, all waste removed, and the hood decontaminated to as low as reasonably achievable.

- Deactivate piping, utilities, and alarms as described in Sect. 2.3.1.4.

- Prepare final facility status report as described in Sect. 2.3.1.6.

- Provide fire protection. The facility does not require a fire protection system. 
$\bullet$

•

- 


\section{WORK PLANS}

\subsection{WORK BREAKDOWN STRUCTURE}

The WBS defines a hierarchy between elements of the IFDP and reflects the lowest level of work package necessary to complete the program. The WBS will be used as a program management tool to

- identify the scope of all work activities;

- plan and schedule work;

- prepare resource budgets to support work;

- develop spending profiles;

- develop subcontract documents; and

- collect technical, schedule, and cost performance data.

Figure 2 illustrates the WBS. A WBS dictionary further defines the scope of work by project participant. All participants will manage and schedule work, collect costs, and evaluate progress in accordance with the WBS at the work package level. Appropriate budget and reporting codes will be applied to ensure that roll-up capability within the WBS structure is protected.

\subsection{PROJECT BASELINE SCHEDULE}

The Energy Systems ER Program is responsible for the preparation and the maintenance of master project schedules. These master project schedules are developed in accordance with the scope defined within the ORNL WBS and contain all controlled milestones. The master project schedule is supported by a number of lower-level schedules created to match activities at levels 7, 8, or lower of the WBS. The sum of the lower-level schedules make up the baseline utilized by Energy Systems for progress determination and control of milestone accomplishment.

The top level IFDP schedule is shown in Fig. 3. Schedules for each facility are shown in Appendix (Sub-Project Schedules). As shown, the IFDP will be complete upon final deactivation of Building 3517 in FY 1999.

The project team established schedule objectives that address the major milestones incorporated into the schedule. These milestones provide points for progress tracking, decision-making, control, and reporting within the master project schedule and lower-level schedules. Project milestones for IFDP will include start and finish of deactivation of each facility and the production of a final facility report. Changes in the planned dates for controlled milestones must be approved in accordance with the DOE-ORO Baseline Control Procedure. All IFDP milestones are listed in Table 2. 
210.2 Isotopes Facilities Deactivation Project

2.10.2.01 Project Administration

2.10.2.01.01 Project Management

2.10.2.01.02 Project Planning

2.10.2.01.02.01 Life Cycle Cost/Risk Analysis

2.10.2.10 Building 3026-C

2.10.2.10.01 RL Light Program

2.10.2.10.02 Tritium Labs 7 \& 16

2.10.2.10.03 Cylinder Disposal

2.10.2.10.04 Krypton Columns 1-4

2.10.2.10.05 Piping, Utilities, and Alarm Deactivation

2.10.2.10.06 Chill Water System

2.10.210.07 Ductwork

2.10.2.10.08 Surveillance and Maintenance

2.10.2.10.09 Final Facility Report

2.10.2.10.10 Fire Protection

2.10.2.11 Building 3026-D

2.10.2.11.01 Clean Out and Deactivate Cells

2.10.2.11.02 Piping, Utilities, and Alarm Deactivation

2.10.2.11.03 Surveillance and Maintenance

2.10.2.11.04 Final Facility Report

2.10.2.11.05 Fire Protection

2.10.2.12 Building 3028

2.10.2.12.01 Clean Out and Deactivate Cells

2.10.2.12.02 Piping, Utilities, and Alarm Deactivation

2.10.2.12.03 Surveillance and Maintenance

2.10.2.12.04 Final Facility Report

2.10.2.12.05 Fire Protection

2.10.2.12.06 Seal Exterior

2.10.2.13 Building 3029

2.10.2.13.01 Clean Out and Deactivate Cells

2.10.2.13.02 Cs-137 Powder Clean-up and Lead Disposal

2.10.2.13.03 Piping, Utilities, and Alarm Deactivation

2.10.2.13.04 Surveillance and Maintenance

2.10.2.13.05 Final Facility Report

2.10.2.13.06 Fire Protection

2.10.2.13.07 Seal Exterior .

2.10.2.14 Building 3030

2.10.2.14.01 Clean Out and Deactivate Cells

2.10.2.14.02 Piping, Utilities, and Alarm Deactivation

2.10.2.14.03 Surveillance and Maintenance

2.10.2.14.04 Final Facility Report

2.10.2.14.05 Seal Exterior

Fig. 2. Work Breakdown Structure. 
2.10.2.15 Building 3031

2.10.2.15.01 Clean Up and Deactivate Cells

2.10.2.15.02 Deactivate Piping Services and Alarm Deactivation

2.10.2.15.03 Re-roof Buildings 3030, 3118, and 3031

2.10.2.15.04 Surveillance and Maintenance

2.10.2.15.05 Final Facility Report 2.10.2.16 Building 3118

2.10.2.16.01 Clean Floors, Seal Cells, and Alarm Deactivation

2.10.2.16.02 Surveillance and Maintenance

2.10.2.16.03 Final Facility Report

2.10.2.17 Building 3033

2.10.2.17.01 Inert Tritium Traps

2.10.2.17.02 Krypton Equipment and Alarm Deactivation

210.2.17.03 Surveillance and Maintenance

2.10.2.17.04 Final Facility Report

2.10.2.17.05 Seal Exterior

2.10.2.18 Building 3033-A

2.10.2.18.01 Clean and Remove Glove Box and Hood

2.10.2.18.02 Roof Repair

2.10.2.18.03 Utilities, Alarm, System Ductwork, and Glove Box Deactivation

2.10.2.18.04 Surveillance and Maintenance

2.10.2.18.05 Final Facility Report

2.10.2.19 Building 3038-AHF

2.10.2.19.01 Cell Clean Up

2.10.2.19.02 Utilities and Alarm Deactivation and Remove Glove Boxes

2.10.2.19.03 Drain Repair

2.10.2.19.04 Surveillance and Maintenance

2.10.2.19.05 Final Facility Report

2.10.2.19.06 Fire Protection

2.10.2.20 Building 3038-E

2.10.2.20.01 Seal and Remove Glove Boxes

2.10.2.20.02 Yttrium Cell Clean-up

2.10.2.20.03 Piping, Utilities, and Alarm Deactivation

2.10.2.20.04 Surveillance and Maintenance

2.10.2.20.05 Final Facility Report

2.10.2.21 Building 3038- $\mathrm{M}$

2.10.2.21.01 Piping, Utilities, and Alarm Deactivation

2.10.2.21.02 Relocate Packaging and Shipping Operations

2.10.2.21.03 Surveillance and Maintenance

2.10.2.21.04 Final Facility Report

Fig. 2. (Continued). 
2.10.2.22 Building 3047

2.10.2.22.01 Chill Water System

2.10.2.22.02 C-14 Glove Box Clean-up

2.10.2.22.03 Hoods

2.10.2.22.04 Vacuum Pit Clean-up

2.10.2.22.05 Filter House Clean-up

2.10.2.22.06 Cell A Clean-up

2.10.2.22.07 Cell B Clean-up

2.10.2.22.08 Cell C Clean-up

2.10.2.22.09 Cell D Clean-up

2.10.2.22.10 Cell D Sump Sludge

2.10.2.22.11 Room 110 Cell Clean-up

2.10.2.22.12 Gad Press Glove Box

2.10.2.22.13 Surveillance and Maintenance

2.10.2.22.14 Final Facility Report

2.10.2.22.15 Fire Protection

2.10.2.22.16 Piping, Utilities, and Alarm Deactivation

2.10.2.23 Building 3517

2.10.2.23.01 Justification for Repackaging

2.10.2.23.02 Facility Upgrades

2.10.2.23.03 Cm-244 Transfer

2.10.2.23.04 Package Co, Eu, Gd, for Retrievable Storage

2.10.2.23.05 Repackage Cs-137

2.10.2.23.06 Repackage Sr-90

2.10.2.23.07 Cell 10E Clean-up

2.10.2.23.08 Cell 10W Clean-up

2.10.2.23.09 Cell 13 Clean-up

2.10.2.23.10 Cell 12 Clean-up

2.10.2.23.11 Cell 14W Clean-up

2.10.2.23.12 Cell 14M Clean-up

2.10.2.23.13 Cell 14E Clean-up

2.10.2.23.14 Cell 11E Clean-up

2.10.2.23.15 Cell 15 Clean-up

2.10.2.23.16 Surveillance and Maintenance

2.10.2.23.17 Final Facility Report

2.10.2.23.18 Fire Protection

2.10.2.23.19 Piping, Utilities, and Alarm Deactivation

2.10.2.24 Building 7025

2.10.2.24.01 Tritium and Hot Smear Clean-up

2.10.2.24.02 Utilities, Water System, and Alarm Deactivation

2.10.2.24.03 Clean Up and Out Equipment and Dispose of Sheds

2.10.2.24.04 Surveillance and Maintenance

2.10.2.24.05 Final Facility Report

Fig. 2. (Continued). 


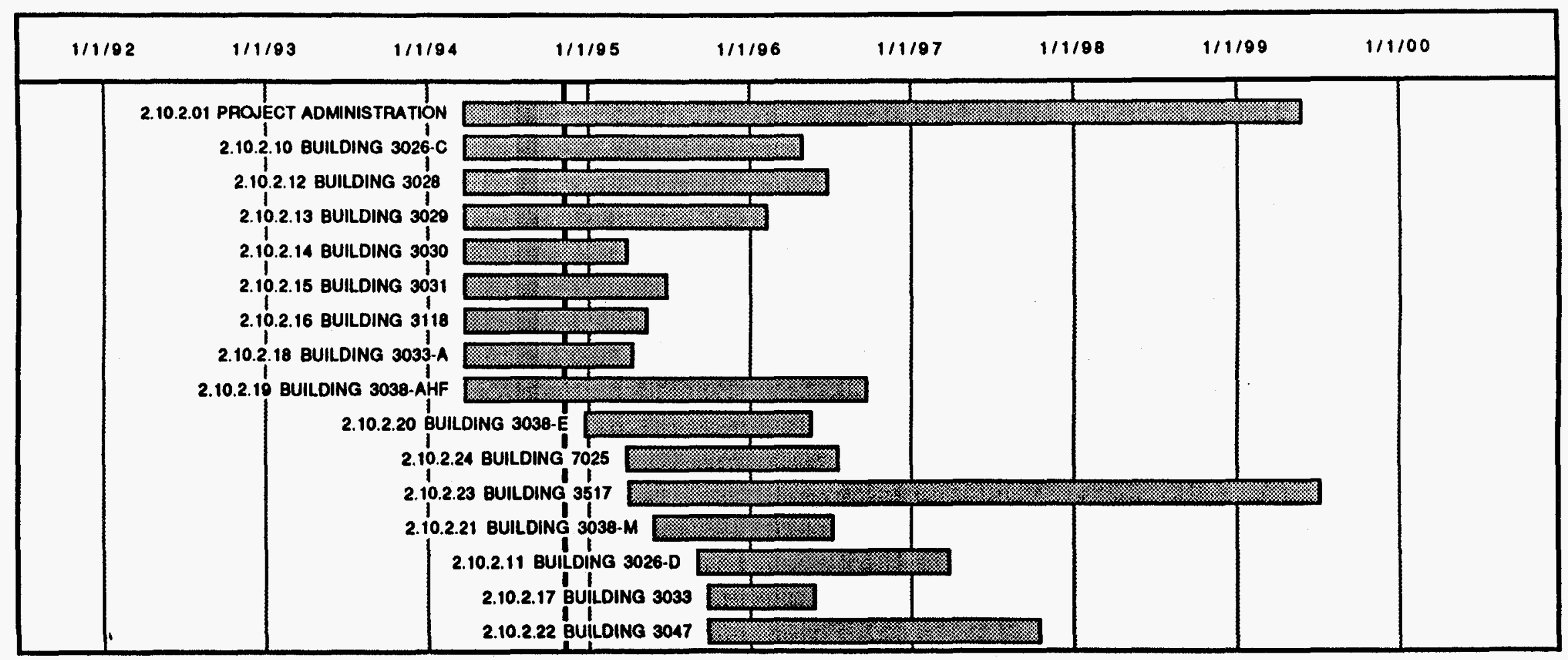

Fig. 3. Isotopes Facilities Deactivation Project schedule. 
Complete deactivation of Building 3026-C

Complete deactivation of Building 3026-D

Complete deactivation of Building 3028

Complete deactivation of Building 3029

Complete deactivation of Building $\mathbf{3 0 3 0}$

Complete deactivation of Building 3031

Complete deactivation of Building 3118

Complete deactivation of Building 3033

Complete deactivation of Building 3033-A

Complete deactivation of Building 3038-AHF

Complete deactivation of Building 3038-E

Complete deactivation of Building 3038-M

Complete deactivation of Building 3047

Complete deactivation of Building 3517

Complete deactivation of Building 7025
May 1996

March 1997

July 1996

February 1996

March 1995

July 1995

October 1995

June 1996

April 1995

September 1996

May 1996

July 1996

October 1997

July 1999

July 1996 
The schedules will include activities to be performed by other DOE prime contractors. On a monthly basis, progress for ongoing activities and future projections will be provided by each prime participant and project team member and supplied to the appropriate Energy Systems Project Manager and Scheduler. This information will be used to update the project schedule and assist the Project Analyst in evaluating project status.

Schedule status will be reviewed by Energy Systems program management, project management, and DOE program management routinely during the normal monthly reporting process required by the monthly status report and progress tracking system.

\subsection{COST BASELINE}

The cost baseline for the project is a time-phased cost estimate to complete the deactivation activities and tum the facilities over to the D\&D Program. The following were used to develop the cost estimate:

- define the project's technical and end-point criteria,

- identify and schedule the individual work elements required to meet the requirements,

- systematically organize the work elements in a WBS, and

- estimate the resources needed to complete the work elements in the WBS using a uniform set of estimating assumptions.

Total estimated IFDP costs are summarized in Table 3. Detailed cost estimates for each deactivation activity are contained in Appendix (Project Cost Estimates).

The project cost estimate is referred to as a baseline because it is integrated with the technical and schedule baseline and is subject to formal change control. This estimate is the sum of the estimates for the individual activities in the control accounts and developed on the automated cost estimating system.

Annual review of the work plan accommodates changes resulting from revised programmatic requirements, budget constraints, or unplanned conditions or changes. As project work proceeds, the total estimated cost and the total project cost are to be updated to reflect the current estimate at completion for both.

The IFDP cost estimate was based upon existing work rules and historical productivity and, therefore, represents conditions expected during the deactivation activities. The level of confidence in the estimate is similar to that expected at the end of the conceptual design phase of a major project, if the work is performed and controlled as described in this report.

The following are key planning assumptions used to prepare the cost estimate.

- D\&D activities will not be performed for at least 10 years beyond the completion of deactivation activities. 
Table 3. Isotopes Facilities Deactivation Project cost summary

\begin{tabular}{|c|c|c|c|c|c|c|c|}
\hline & FY 1995 & FY 1996 & FY 1997 & FY 1998 & FY 1999 & FY 2000 & TOTAL \\
\hline Project Management & 929 & 665 & 698 & 625 & 230 & 119 & 3266 \\
\hline Surveillance and Maintenance & 4740 & 3941 & 2881 & 1911 & 1191 & 951 & 15615 \\
\hline Deactivation & 3950 & 6073 & 4578 & 1572 & 702 & 0 & 26140 \\
\hline TOTAL & 9619 & 10679 & 8157 & 4108 & 2123 & 1070 & 35756 \\
\hline
\end{tabular}


- All of the deactivation activities are covered by existing ORNL National Environmental Policy Act (NEPA) documentation. Any additional NEPA documentation will be completed in parallel with other project activities with additional resources.

- Waste tanks WC-10 and WC-2 will be available to support deactivation activities through FY 1997.

- Trained and qualified personnel are available to perform deactivation activities.

- Work inefficiencies are expected for radiation work involving respirators or supplied air.

- ORRs will be conducted by the project staff or by an appointed review committee. No other ORRs will be required.

- The only activity that has been identified as potentially requiring an ORR is the resumption of repackaging operations in Building 3517 (Sect. 2.2.3.12).

- Technical planning bases for the project will be implemented as described. Appropriate project contingency will be provided and identified.

- The IFDP will continue to fund S\&M of a facility until the end of the fiscal year following the year in which deactivation is complete. At that time, the facility is transitioned into D\&D (i.e. a facility deactivated in FY 1995 will be transitioned to $D \& D$ at the beginning of FY 1997).

- Budget will be provided as planned in the funding profile.

The cost estimate was compiled by Energy Systems Engineering from the estimates prepared by the ORNL organizations performing the work. The estimating methodologies and practices conform to the Energy Systems Project Estimating and Scheduling Standard Operating Manual, the DOE-ORO Estimating and Cost Control Manual for Construction Projects, and the Cost Estimating Hand Book for Environmental Restoration Projects. The estimate is an activity-based cost estimate.

The resource data used to prepare the cost estimate are derived from current cost data and staffing requirements for existing work elements that continue for the duration of the project and from technical work descriptions and schedules prepared for each deactivation activity.

The estimate for each work element was reviewed by knowledgeable plant staff for uniformity and reasonableness prior to acceptance into the cost estimate.

The resources were priced using labor rates developed from the existing financial system. The indirect costs, including steam and water use assessments, organization overheads, material procurement, and general and administrative burdens, were developed similarly. 
Comparisons of the deactivation resource mix with the existing resource mix were made and the changes reconciled with work content differences. Where necessary, cost allowances were made based upon historical usage rates, including materials and MK-Ferguson construction forces.

\subsection{PROJECT ORGANIZATION AND RESPONSIBILITIES}

This project is managed by the ORNL ER Program and supported by an integrated team of Energy Systems and subcontract personnel. The following discussion provides functional descriptions of the key management and the support organization that makes up the IFDP.

\subsubsection{ORNL Environmental Restoration Program}

The ORNL ER Program is responsible for supporting the DOE-ORO project office with day-to-day technical management, coordination, control, and reporting of project activities identified in this work plan.

The IFDP Manager plans, coordinates, and directs project execution, including technical direction; development and administration of project criteria; and baseline system analysis, scheduling, budgeting, configuration management, and reporting. The IFDP Manager receives policy guidance and project instructions from the DOEORO Project Manager. The IFDP Manager reports to the ORNL ER Program Manager.

The IFDP Manager is responsible for the following.

- Define and administer the technical cost and schedule requirements for the project.

- Develop the project work plan and project management plan.

- Manage and control project baseline, as well as the timely identification and communication of real and potential problems to the DOE-ORO Project Manager.

- Provide the DOE-ORO project office with a clear and concise narrative report of project status with respect to established project baseline.

\subsubsection{Chemical Technology Division}

The Chemical Technology Division provides the facility management function for the IFDP under the direction of the ORNL ER Program. The roles and responsibilities of the Chemical Technology Division include the following.

- Provide facility management for all IFDP facilities to include occurrence reporting, safety documentation, maintenance, configuration control, and administrative control of all activities. 
- Provide S\&M for IFDP buildings, including 3026-C, 3026-D, 3028, 3029, 3030, 3031, 3033, 3033-A, 3038-E, 3038-M, 3038-AHF, 3047, 3118, 7025, and 3517, and all ancillary buildings, storage pads, filter houses, and attachments to these buildings.

- Identify and recommend $S \& M$ and deactivation activities and prepare estimates and task duration for activities to meet the IFDP programmatic objectives.

- Perform deactivation and cleanup activities associated with IFDP facilities, including supervision of maintenance, maintenance of facilities, cleanup of contamination and contaminated equipment, filter replacement, equipment maintenance, and waste handling.

- Provide emergency services for IFDP facilities including handling of rainwater inleakage to waste systems, leaking roof problems, leaking steam and water lines, and other equipment failure.

- Provide maintenance of radioactive materials and other hazardous materials inventories and monitoring of inventoried materials (including maintenance and monitoring of satellite waste accumulation areas).

- Assist in the planning of D\&D activities in these facilities.

- Assist in the special design of remote equipment and fixtures to facilitate radioactive material handling, contamination isolation, and cleanup.

\subsubsection{Plant and Equipment Division}

The roles and responsibilities of Plant and Equipment Division personnel include the following.

- Provide maintenance support for IFDP facilities to include electrical, pipe fitter, mechanical (millwright), special services such as contamination bonding and manipulator and manipulator boot repair, and labor and janitorial services.

\subsubsection{Instrumentation and Controls Division}

The roles and responsibilities of Instrumentation and Controls Division personnel include the following.

- Provide maintenance for RP instrumentation and other equipment specified in the OSRs and Limiting Conditions for Operations Document (LCDs) for the IFDP facilities. This requirement includes maintaining a data base of instruments required for safe operation of the building and routine maintenance of the instruments as well as nonroutine equipment (instrument) repair.

- Provide technical support on equipment specification and maintenance. 


\subsubsection{Office of Radiation Protection}

The roles and responsibilities of RP personnel in IFDP facilities include the following.

- Provide RP services including instrument checks, routine surveillance, posting, surveillance of work activities, and instrument calibration and maintenance of $R P$ instrumentation.

- Provide technical support on RP instrumentation specification and maintenance.

\subsubsection{Center for Risk Management}

The Center for Risk Management (CRM) will provide the IFDP with risk and cost analysis and decision support. The objective of this support is to help ORNL ER and the IFDP optimize decisions relating to facility S\&M, deactivation, transition, and disposition. The CRM will conduct screening-level risk evaluations to determine and communicate baseline facility risks and evaluate current and life cycle IFDP costs to identify S\&M cost savings. The CRM will also develop an FDDM to provide the IFDP with direct input regarding the cost and risk benefits and trade-offs associated with project alternatives in the project WBS and additional D\&D alternatives as requested. It will include consideration of waste disposition alternatives and criteria through direct cooperation with the ER Waste Management Program. 


\section{SUPPORTING PLANS}

\subsection{SURVEILLANCE AND MAINTENANCE}

The IFDP will place the facilities in a safe and environmentally sound condition in an economical manner. The S\&M plan will ensure that the facilities are maintained in a safe condition during the post-deactivation surveillance period while awaiting the start of D\&D activities. DOE Order 5820.2A, Radioactive Waste Management, Chapter V, "Decommissioning of Radioactively Contaminated Facilities," requires that an S\&M program be developed and implemented with documented evidence that the checks and inspections are being conducted and the required maintenance is being performed to keep the facility in a safe condition pending the final disposition.

The DOE Policy Memorandum for Acceptance of Facilities for ER Program issued March 15, 1991, by L. F. Duffy requires IFDP facilities to be in a radiologically safe condition following deactivation. The following is the basis for the S\&M plan.

- The facilities shall be in a physical condition adequate to contain and monitor any radioactive contamination. An "as left" radiation contamination survey of the facilities and surrounding areas will be included in the deactivation records.

- Security systems and procedures shall be adequate to prevent unauthorized entry.

- Special nuclear materials; reactor fuels; and solid and liquid radioactive, hazardous, and mixed waste shall be removed from the facility or the location, and controls shall be documented and approved for those materials for which an end condition cannot be determined. Any exceptions of nuclear and hazardous material remaining in the facility shall be identified and characterized by location, type, and quantity.

To meet the S\&M requirements, the IFDP work plan must ensure that provisions are made to:

- sustain systems required for monitoring and emission control;

- sustain operation of systems required for protection of surveillance personnel, the general public and environment, and vital equipment;

- sustain systems to respond to emergency conditions expected in the facilities' deactivated state; and

- sustain systems required to prevent structural degradation.

This section presents a summary-level description of the expected contents of the plan. The plan will be expanded and detailed as the project proceeds.

\subsubsection{Deactivated Facility Status}

The facility status expected at the end of the project is described in Sect. 2.2.5. The status described is the assumed condition to be used in preparing the S\&M plan. 


\subsubsection{Surveillance and Maintenance Plan}

Based on prior deactivation experience, the post-deactivation S\&M plan will require the following functions.

\subsubsection{Radiation and environmental monitoring}

Monitoring during the surveillance period includes the following.

- Radiation protection, to the extent required for worker protection during facility surveillance entries, will be in agreement with

- DOE Order 5480.11, Radiation Protection for Occupational Workers; and

- DOE Order 5480.6, Radiological Control Manual.

- Periodic radiation surveys will be conducted to confirm the baseline surveys and to detect any unexpected changes.

\subsubsection{Radiological control}

S\&M of remaining facilities that provide radiological control are limited to the operation of the central ventilation system; the process off-gas system; and the heating, ventilation, and air conditioning (HVAC) system in facilities. Surveillance of system performance will provide assurance of proper confinement function.

\subsubsection{Monitors and alarms}

Continuous monitoring will be provided for the following.

- Electrical power distribution status.

- Central ventilation system monitoring of zone differential pressures, exhaust filter differential pressures, and temperature.

The monitoring system will have the capability to communicate with the Waste Operation Control Center at ORNL.

\subsubsection{Facility and access control devices}

S\&M of the facilities and access control during the post-deactivation period include surveillance of the following:

- doors for security and access protection;

- external housekeeping to avoid accumulation of combustibles near the facilities;

- the exterior structure, roof, and access doors to verify no indication of potential or ongoing degradation of the structure or accesses; 
- the interior to ensure that deactivated facilities conditions are retained and to reduce the risk of contamination spread due to intrusion by small animals or birds; and

- signs and restricted area posting/barriers to ensure that proper warnings and exposure controls remain in place for worker protection.

\subsubsection{Emergency preparedness}

S\&M of remaining active facilities that provide emergency services include the following:

- fire alarm system, and

- backup power for the unmanned monitoring systems.

\subsubsection{Surveillance Frequency}

The post-deactivation plan will be developed during the project. The frequencies specified here are based on experience at similar DOE facilities during extended outages and commercial nuclear experience. To the greatest practical extent, all surveillance will be conducted without entering the confinement structure. When entries are required, workers will follow a predetermined path and use checklists to ensure that a single entry fulfills the internal inspection requirements.

\subsubsection{Weekly surveillance}

Surveillance will be performed weekly on the following:

- ventilation system differential pressure;

- personnel access control; and

- surveillance "walk thru" of Building 3047 and Building 3517.

\subsubsection{Monthly surveillance}

Surveillance will be performed monthly on the following:

- grounds housekeeping, and

- exterior signs and restricted area posting/barriers.

\subsubsection{Quarterly surveillance}

Surveillance will be performed quarterly on the following:

- fire alarm system,

- internal facilities inspection, and

- external facilities inspection. 


\subsubsection{Surveillance and Maintenance Costs}

A major objective of the IFDP is to reduce $S \& M$ costs to a minimum during the period between deactivation and D\&D. Table 4 is a conservative estimate of the total S\&M costs associated with these facilities through FY 2000 . As the detailed postdeactivation S\&M plans are refined, these estimates will be revised and are anticipated to be lower. The revised estimates will be reflected in subsequent revisions of this work plan.

Table 4. Surveillance and Maintenance Costs $(\$ \times 1000)$

BUILDING

FISCAL YEAR

\begin{tabular}{lrrrrrrr}
\hline & 1994 & 1995 & 1996 & 1997 & 1998 & 1999 & 2000 \\
$3026-\mathrm{C}$ & 240 & 240 & 96 & 48 & 48 & 48 & 48 \\
$3026-\mathrm{D}$ & 200 & 200 & 200 & 120 & 40 & 40 & 40 \\
3028 & 200 & 200 & 40 & 40 & 40 & 40 & 40 \\
3029 & 420 & 420 & 262 & 84 & 84 & 84 & 84 \\
3030 & 70 & 70 & 15 & 15 & 15 & 15 & 15 \\
3118 & 30 & 30 & 6 & 6 & 6 & 6 & 6 \\
3031 & 70 & 70 & 15 & 15 & 15 & 15 & 15 \\
3032 & 70 & 70 & 15 & 15 & 15 & 15 & 15 \\
3033 & 80 & 80 & 80 & 16 & 16 & 16 & 16 \\
$3033-\mathrm{A}$ & 80 & 80 & 16 & 16 & 16 & 16 & 16 \\
3034 & 80 & 80 & 16 & 16 & 16 & 16 & 16 \\
$3038-\mathrm{A}$ & 400 & 400 & 400 & 160 & 80 & 80 & 80 \\
$3038-\mathrm{M}$ & 150 & 150 & 90 & 30 & 30 & 30 & 30 \\
$3038-\mathrm{E}$ & 400 & 400 & 400 & 80 & 80 & 80 & 80 \\
3047 & 950 & 950 & 950 & 950 & 190 & 190 & 190 \\
3517 & 1200 & 1200 & 1200 & 1200 & 1200 & 480 & 240 \\
7025 & 100 & 100 & 60 & 20 & 20 & 20 & 20 \\
& & & & & & & \\
TOTAL & 4740 & 4740 & 3941 & 2831 & 1911 & 1191 & 951 \\
\hline
\end{tabular}

\subsubsection{Reporting}

Notification and reporting of events will be in accordance with DOE Order 5000.3B, Occurrence Reporting and Processing of Operations Information, as implemented by ORNL facility-specific procedures. 


\subsection{SAFETY DOCUMENTATION PLAN}

\subsubsection{Status of Existing Safety Documentation}

All activities in IFDP facilities are controlled by appropriate safety documentation. Changes to facility or operations are evaluated by the Unreviewed Safety Question Determination (USQD) process (Sect. 4.2.3) before being implemented. IFDP operations are presently governed by the ORNL-approved Safety Analysis Reports (SARs), Safety Assessment (SA), or HSD. The OSRs currently in force were approved by DOE-ORO in 1991. Facilities that do not have OSRs operate under an ORNLapproved LCD. The current OSRs or LCDs update the facilities' operational status and identify controls needed for the facilities' limited missions of deactivation activities or storage of excess inventories of radioisotopes.

As deactivation activities proceed to the point hazards are adequately reduced, SARs and OSRs are retired and replaced with the lower-level safety documentation (HSD and LCD). The retirement of the SAR/OSR for Buildings 3026-C, 3026-D, 3028, $3029,3033,3033-A$, and 7025 has been accomplished. The only SAR required in the long term is needed to address the hazards of radioactive material storage for the Fission Products Development Laboratory (FPDL). The SAR for FPDL, Building 3517, is being upgraded through the Energy Systems Safety Analysis Report Update Program (SARUP). The estimated cost of updating the Building 3517 SAR is $\$ 1,00 \mathrm{~K}$. A description of this update program and the status of the FPDL document is provided in Sect. 4.2.

Low-risk activities that do not represent significant hazard and are therefore not addressed specifically in the SARs or SAs are governed by problem safety summaries (PSSs), which are described in Sect. 4.2.4.

The specified safety documentation that exists for all IFDP facilities and that which is planned is presented in Table 5.

\subsubsection{Description and Status of Safety Analysis Report Upgrade Program}

The SARUP consists of five phases:

- Phase 0-continued operation evaluation,

- Phase I-hazard classification and qualitative analysis,

- Phase IA-updated OSRs,

- Phase II-quantitative accident analysis, and

- Phase III-complete DOE-approved SARs. 
Table 5. Facility safety documentation

\begin{tabular}{llcll}
\hline Facility & $\begin{array}{l}\text { Existing Safety } \\
\text { Operating } \\
\text { Controls }\end{array}$ & Analysis & $\begin{array}{l}\text { Planned Safety Decumentation } \\
\text { Operating } \\
\text { Controls }\end{array}$ & Analysis \\
\hline $3026-$ C & LCD & HSD & LCD & HSD \\
3028 & LCD & HSD & LCD & HSD \\
3029 & OSR & SAR & LCD & HSD \\
3030 & N/A & SA & N/A & PSS \\
3031 & N/A & SA & N/A & PSS \\
3033 & LCD & HSD & LCD & HSD \\
$3033-A$ & LCD & HSD & LCD & HSD \\
3038 & OSR & SAR & LCD & HSD \\
3047 & OSR & SAR & LCD & HSD \\
3118 & N/A & PSS & N/A & PSS \\
3517 & OSR & SAR & OSR & SAR \\
7025 & LCD & HSD & LCD & HSD \\
\hline
\end{tabular}

'Problem Safety Summaries are prepared as needed but are not presently needed in all facilities.

Legend: LCD. Limiting Conditions Document; HSD, Hazard Screening Documents;

OSR, Operational Safety Requirements; SAR, Safety Analysis Report; N/A, not applicable; SA, Safety Assessment; PSS, Problem Safety Summary.

The primary aspect of the program is based on a risk prioritization of activities. In contrast with a serial approach that would update one (or a small group) of SARs and then update the next (or a small group), the program is designed to address all ORNL facilities simultaneously and proceed within a given phase and from one phase to the next based upon hazard and risk. In this manner, the most significant safety aspects of all facilities undergo today's analytic rigor and completeness in a more timely fashion, leaving those aspects of lesser hazard/risk significance to the later years of the program.

A graphic description of the SARUP is shown in Fig. 4. Phase 0, completed in early FY 1990, served to evaluate continued operations. Facilities covered in this phase were those judged to involve significant (moderate to high) hazards. Facility Safety Evaluation Teams (FSETs) were formed for each of these facilities to examine risks according to a checklist method. The team composition relied heavily on the participation of personnel from the operating divisions.

Results of these evaluations were presented to Plant Safety Evaluation Teams (PSETs) for acceptability. The PSETs (one per installation) consisted of technical and management representatives of both DOE-ORO and Energy Systems. Action plans based upon Phase 0 risk results were developed to reduce risks; these either have been completed or are ongoing. Recognition by FSET personnel of the benefits of 


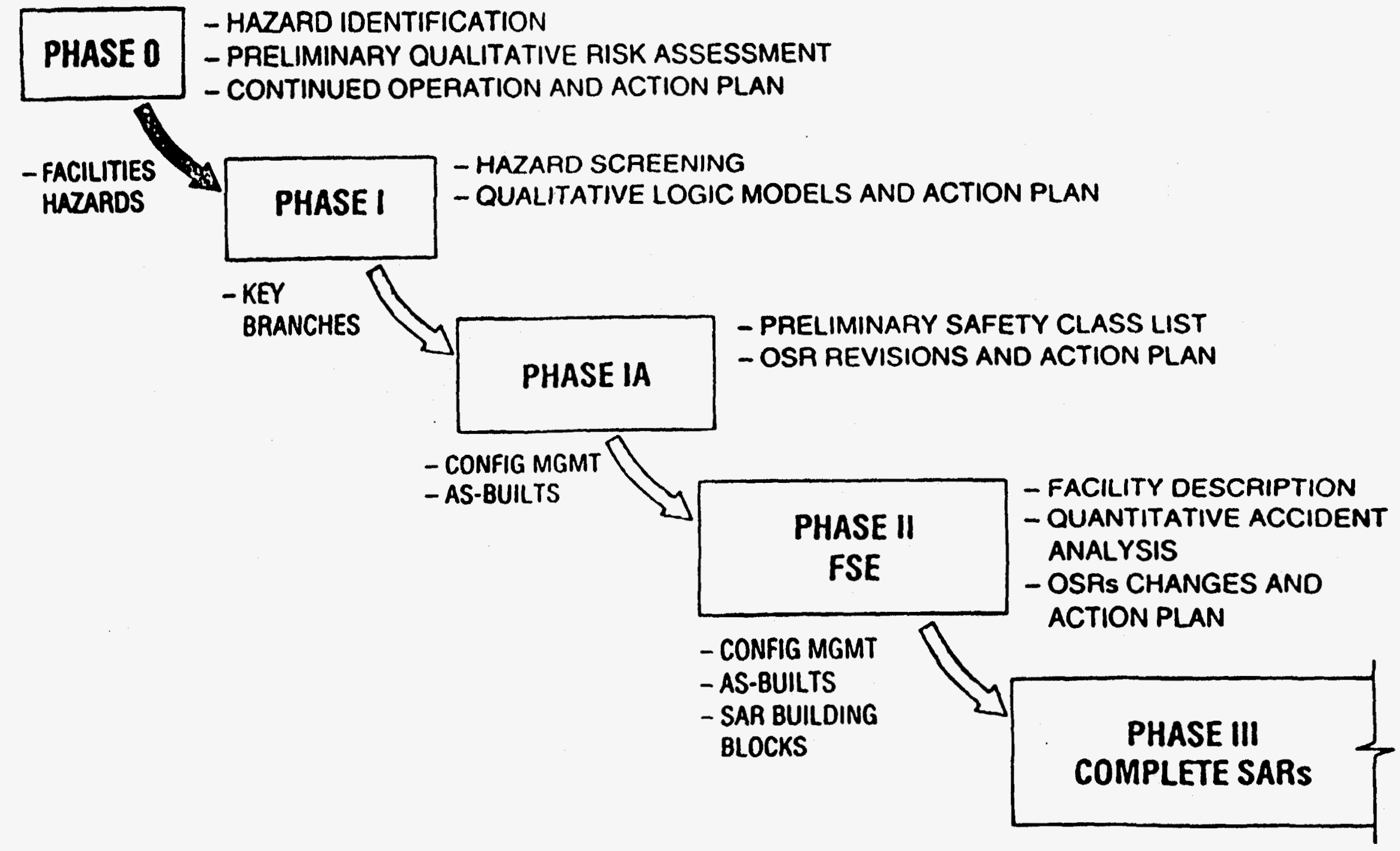

Fig. 4. Safety Analysis Report Update Program. 
Phase 0 was evident, especially the effective involvement of operating personnel with safety analysis and management.

In Phase I, facilities which involve insignificant hazards or for which standard industrial practices (as defined by national codes and standards) are adequate to define safe operating hardware and procedures are identified through a preliminary hazard screening process. These facilities will be required to maintain their operations within these standard industrial hazard control limits or to revise their preliminary HSD accordingly. They will not be subjected to further safety analysis. Those facilities that clearly pose significant hazards or that are questionable on this respect will undergo a more analytical hazard screening process. The outcome of this analysis will identify facility aspects which will undergo further qualitative analysis in Phase I as well as quantitative analysis in Phase II.

Phase IA has been established as a follow-on bridge between Phase I and Phase II. This intermediate phase was created primarily to provide for updating of existing OSRs to the extent supported by the technical bases developed during Phase I. Also, by identifying significant features of each facility, the safety-related configuration management and as-built needs will be identified. Finally, risk reduction action plans will be prepared when needs are identified.

Phase II of the program extends Phase I in a quantitative manner, resulting in an abbreviated safety analysis document that will include a facility description, the significant accident analysis, and the OSRs which comprise the heart of the safety analysis. This early focus on the fundamental elements of a given SAR for significant hazards is another key aspect of the program since it allows establishing the analytical basis for OSRs at the earliest possible date. It identifies further definition of configuration management and as-built needs. This phase of the program was completed in the FY 1992-93 time frame. Full SARs will be produced in Phase III, with predicted completion dates occurring between FY 1995 and FY 1998.

During the time period in which the SARUP is being accomplished, there will be certain new facilities and facility modifications for which stand-alone SARs may be prepared. A transition plan will be developed for each of these efforts so that document consolidation is effected in a timely fashion.

Discussions with DOE-ORO have led to the conclusion that substantial amounts of information about each installation will be common to all safety documents for that installation. Rather than repeat this information in each safety document, generic documents will be prepared. These documents will describe meteorological conditions, demographic data, safety organizations, and other common features.

The SARUP described in this section is now being applied to the IFDP facilities. Phase 0, Phase I, and Phase IA of the process have been completed. Phase II and Phase III are required only for FPDL, Building 3517. These phases will begin in FY 1996. 


\subsubsection{Unreviewed Safety Question Determination Process and Status}

The definition and basis for determining the existence of an unreviewed safety question are contained within DOE Order 5480.21. All changes to physical or procedural elements within IFDP facilities are reviewed to determine what impact, if any, will result from the anticipated change and to ensure that operational restrictions are provided as warranted.

The USQD review process is integrated into all aspects of the organization responsible for design, engineering, maintenance, inspection, operations, and assessment of the facilities and their activities.

The facility OSRs, SARs, LCDs, HSDs, and SAs (as appropriate) provide the "base line" for procedural and physical elements subject to the USQD process. Any of these elements that are altered to accommodate a project or activity not described in these or other safety analyses, or any changes to the OSRs or LCDs, would require an USQD.

\section{Situations assumed to involve an USQD include}

- probability of occurrence or the consequences of an accident or malfunction of equipment important to safety previously evaluated in a facility safety analysis could be increased;

- possibility for an accident or malfunction of a different type other than any evaluated previously in the facility safety analyses could be created; or

- any margin of safety defined in the OSR/LCD could be reduced.

Changes to facility physical elements, procedural controls, and new project activities or experiments are evaluated by the Facility Manager to determine if the requested change should be subject to the USQD process. A positive determination by the Facility Manager requires that a review of the activity be conducted by operations personnel, members of an FSET, and the System Safety Engineering Department, and that approval of the determination be made by the Facility Manager, the Division Director, and the Director of the Office of Operational Readiness and Facility Safety.

Members of the FSET are appointed by the head of the Radiochemical Technology Section (RTS). System Safety Engineering Department personnel are assigned to specific USQD reviews by the System Safety Engineering Department Manager.

The USQD is documented using the outline provided within DOE Order 5480.21. Copies of the determination are maintained in duplicate file points within the affected facility and the RTS office.

\subsubsection{Description of Problem Safety Summary Report}

PSSs are prepared for low-risk experiments not specifically discussed in the SAR or covered by specific procedures, and conducted within IFDP facilities. 
The scope and administration of PSSs are described in the Safety Manual for the Radiochemical Technology Section of the Chemical Technology Division. An example of a problem safety outline is provided Fig. 5.

Every person (engineer, scientist, technician, and operator) working on a program or experiment within an IFDP facility is required to have read the PSS for that activity. A copy of a PSS is placed in a protective binder and located at the entry/exit to the work area involved.

Appropriate distribution of a PSS is conducted by the RTS Document Control Center where the record copies are retained.

\subsection{QUALITY ASSURANCE}

The RTS within the Chemical Technology Division has an established QA plan, QAP X-91-CT-006, that is implemented for activities conducted in and for facilities within the scope of the IFDP. Implementation of this plan ensures achievement of IFDP objectives in a safe, reliable, and predictable manner.

The RTS QA plan is responsive to the requirements of the Energy Systems QA plan, Y/QD-15, DOE Order 5700.6C, and Title 10 Code of Federal Regulations Part 830.120. This plan is prepared and approved in accordance with QA-3, "Procedure for QA Planning," of the Chemical Technology Division Policies, Standards, and Procedures Manual. The plan is a working document that requires updating as activity or project needs change.

The responsibilities and authorities for the QA program are defined in the draft IFDP Management Plan, ORNL/ER-230. The QA program is a management system that reflects management's strategy for accomplishing the objectives of the IFDP.

The RTS promotes the concept that quality shall be integrated into the work processes through each individual employee who has been properly trained, motivated, and empowered, and who is knowledgeable of the procedures, instructions, and other related administrative and technical documents that control the work.

\subsection{WASTE MANAGEMENT}

Waste generated during the IFDP will be managed in accordance with DOE Orders 5400.1, General Environmental Protection Program; 5400.3, Hazardous and Radioactive Waste Program; and 5820.2A, Resource Conservation and Recovery Act as amended. Waste minimization programs to control waste generation have been established for the IFDP.

This section describes the handling, treatment, and disposal of project waste and summarizes the techniques that are planned for waste minimization during the project. 
RTS No

\section{PROBLEM SAFETY SUMMARY}

DATE:

PROBLEMNAME:

LOCATION:

\section{PROBLEM ZEADER AND RESPONSIBLE ALTERNATES}

Give the names, home addresses, and plant and home telcphone number of persons familiar with and tesponsible for the operation who may be contacted in case of emergency. For Soction nuclear facilties requiring edditional safety analysis review (e.g, hot cells and plutonlum glove boxes), the operating personnel must be trained and qualified to carry out their assigned responsibilities (sce DOE Order 5480.5).

Name

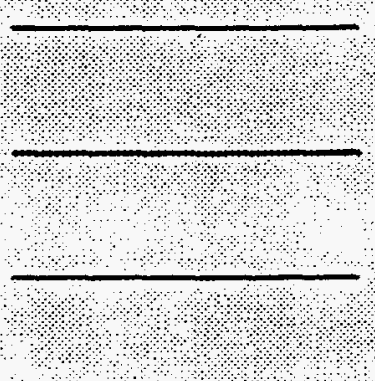

SIGNATURES:

\section{Addres}
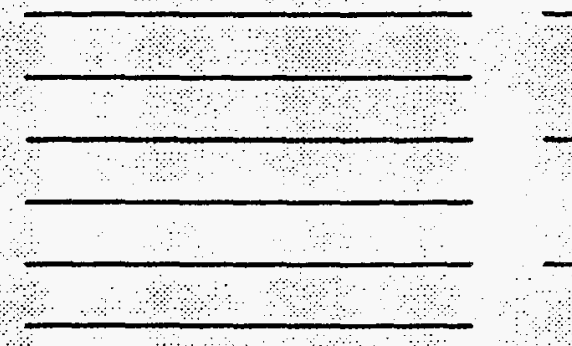

Home Phone

Plant Phone
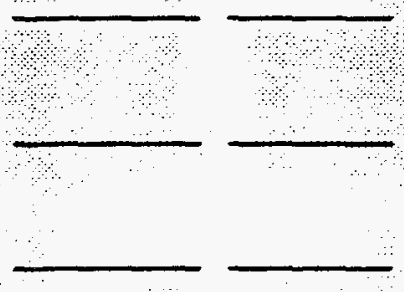

Pesentin Chage

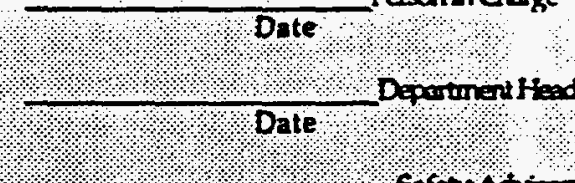

Sares Aaviony Commiltee Chaiman

Date

Rodfochentical Technology Section - Salety Officer

Date

Radiochemial Tednology Section Head

Date

Fig. 5. Example of Problem Safety Summary. 


\section{CHECKLIST FOR PRINCIPAL HAZARDS}

Indicate the type of experdmental or process havards involved. Do not inctude routine hazards common to expertmental work ouch as $110 / 220$ V electric pown, stngle high-presaure cyllinders of inert gas, etc. This chectliet thould be included on the first or second page of the Safely Summary.

Hazardous diemiculs

High-pressure equipment 6150 pot

High temperature $>2500$

Hith roltage $(<220 \mathrm{~V})$

Flammable gases

Fibrous materisils

Radioactivity:

othe

\section{PROCESS DESCRIPTION AND SHUTDOWN PROCEDURES}

Gre a shont general description of the experimental or processing equipment, a low shet and a listing of

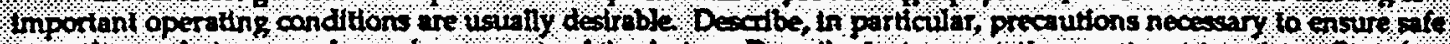
operation and given any hazardous aspects of the design. Describe instrumentation pertinent to safety. Give the emergency shutdown procedure, emphasizing any particular precautions necessary.

\section{MATERIALS HANDLED}

When hazardous materials are involved, dab should be included on explosive finits, flammability, reactivity, toxidty, and physiologieal effects. Relale these restrainis to particular precautions to be observed in material handling. Note symptoms of exposure and first ald for these hazardous materials. A Material Safety Data Sheet (MSDS) should be atthched for each hazardous chemical $A$ chemical usage plan (see $p$ p $27-30$ of he CTD Cientical Hygiene Plan) should be attached.

\section{RADLATION HAZARD CONSIDERATIONS}

When handling radioactive materials, the Healih Pbysics Procedures Manual shoutd be consulted tespecially RP.2.16, Appendix A, B, and C. The activity and chemical form of the material used for each experiment or process should be spedfled. Any special facilities or handling precautions should be discussed, and attention should be given to an evaluation of the overall hazard (probability of dispersing the activity).

\section{MDNMUM SAFETY RECULATIONS FOR PERSONNEL}

When any formatization of the operation an be defined, this section should be used to spell out the particular safety rules important to the problem. These should inciude eye protection, protective apparel, smoking limitations, and radiation monitoring when the measures are of particular importance due to the hazards. involved. Routine safety rutes do not need to be listed.

\section{UTILTIES AND CENERAL SAFETY FIOLIMES}

Consider the effect of this experimental progran or process on the building ventilation, process (or potable) wate, power, drains, ete Particular attention should be given to the possibility of hazrids spreading to other working areas Note the adequacy of avaltable fireth ofiting equip nent and oommunications

\section{WASTE DISPOSAL.}

Consider what types o waste will be generated (process wastewater, LULW, hazardous, mixed, ete) and How they will be handled.

\section{QUAUTY ASSURANCE}

Make $\mathrm{QA}$ assessment in ascordance with ORNL QA Procedure, QA-L-2-100. Include results of assessment in this section.

Fig. 5. Example of Problem Safety Summary (continued). 


\subsubsection{Effluent}

There are three liquid and three gaseous effuent discharges from IFDP facilities.

\subsubsection{Gaseous effluent}

ORNL has two central systems in the main plant area for handling waste gases: the cell ventilation system and the process off-gas system, which discharge to the Building 3039 stack. Waste gases that may contain radioactivity are treated at the source facility to reduce the radioactivity to acceptable levels before they are discharged to the central system. The form of the radioactivity determines the type of cleanup procedure used. Radioactive particulates are removed from air streams using high-efficiency particulate air (HEPA) filters.

The central cell ventilation systems, sometimes called the "high-volume, lowlevel" systems, are designed to handle the waste streams from hot cells and limited access areas. The average flow through the cell ventilation system is 155,400 std $\mathrm{ft}^{3} / \mathrm{min}$ ( $98 \%$ of stack flow). There are five area systems, each of which is serviced by an electric blower with steam turbine backup. Emergency power is supplied to all cell ventilation fans (except the Oak Ridge Research Reactor); however, there is no treatment of cell ventilation gases at the Building 3039 stack facility. The buildings in this shutdown plan that are served by the central cell ventilation service are listed in Table 6, along with other buildings on the same blower.

The process off-gas system is designed to handle the off-gases from process equipment and laboratory experiments or under conditions where reduced pressure is required. It is a much smaller volume than the cell ventilation waste. The normal flow is $4000 \mathrm{std} \mathrm{ft}^{3} / \mathrm{min}$ at a negative pressure of $42 \mathrm{in}$. w.g. The process off-gas waste stream is treated at the Building 3039 facility before discharge to the stack. The central treatment system includes a venturi scrubber to remove acid fumes, a demister, roughing filters, and HEPA filtration. The system has steam turbine backup in case of loss of power.

Buildings 3028, 3029, 3033, 3038, and 3047 are equipped with local ventilation systems that are designed to keep secondary containment areas at a negative pressure relative to the exterior of the building. The systems in Buildings 3028, 3033, and 3038 are on continuously, whereas the systems in Buildings 3029 and 3047 are tripped by alarms from monitrons or continuous air monitors in these facilities. The discharge from a local ventilation system is passed through two stages of HEPA filters and exhausted through stacks on the top of each facility. Building 3517 has a "continuously on" containment system that discharges through the building cells to the Building 3039 stack.

Various combinations of local ventilation systems with roof exhaust fans, the Building 3039 cell ventilation system, and/or the Building 3039 process off-gas system are used in the isotopes buildings in this shutdown plan. These are given in the descriptions of the individual buildings (Appendix A). Note that cell ventilation air from alpha hot cells is exhausted to the Building 3039 process off-gas system, which provides secondary treatment. 
Table 6. Building 3039 stack cell ventilation service for buildings in the Isotopes Facilities Deactivation Project

\begin{tabular}{llc}
\hline Blower & $\begin{array}{c}\text { IFDP buildings } \\
\text { serviced by blower }\end{array}$ & $\begin{array}{c}\text { Other buildings } \\
\text { sharing the blower }\end{array}$ \\
\hline Isotopes area & 3028 & 3005 \\
$\left(48,000{\left.\text { std } \mathrm{ft}^{3} / \mathrm{min}\right)}\right.$ & 3029 & 3098 \\
& 3030 & \\
& 3031 & \\
& 3033 & \\
& $3033-\mathrm{A}$ & \\
& 3038 & \\
3025,3026 area & 3047 & 3025 \\
$\left(34,000 \mathrm{std}^{3} / \mathrm{min}\right)$ & & \\
3500 area $\left(24,000 \mathrm{std} \mathrm{ft}^{3} / \mathrm{min}\right)$ & 3526 & 2531 \\
& 3517 & 2537 \\
& & 3505 \\
& & 3506 \\
& & 3507 \\
\hline
\end{tabular}

There are no current plans to deactivate any of the ventilation systems serving IFDP facilities. There will be some decrease in flow to the central cell ventilation system due to the removal and disposal of glove boxes. However, it is not cost effective to take hot cells off of ventilation. This service is provided at no cost to these facilities, and major facility modifications would be required to terminate ventilation of hot cells. Even if IFDP facilities were removed from the central ventilation system, DOE would not see any reduction in cost as the system must continue to operate to service other ORNL facilities.

The local ventilation systems may be taken out of service pending the results of a life cycle cost/risk analysis to be performed on the options of deactivation versus continued operation. This analysis will be completed in FY 1995.

\subsubsection{Liquid low-level waste system}

Most of the isotopes facilities are equipped with "hot" drains located in hot cells, glove boxes, hoods, and occasionally floor drains that are connected to the ORNL LLLW system. Typically, waste that is collected in "hot" drains flows by gravity through pipes to underground collection tanks where the waste is neutralized, if necessary. The piping and tanks are known as the collection and transfer system 
(CAT). The waste accumulated in the collection tanks is transferred via underground piping to the SLLW evaporator facility (Building 2531), where it is concentrated in one of two evaporator units. The evaporator overheads are condensed and transferred to the process waste treatment plant (PWTP) for further treatment. The concentrated waste is stored in stainless steel tanks. The storage tanks are located in below-grade, shielded-concrete vaults with stainless steel liners. Transfers are handled remotely. This system minimizes the radiation exposure to personnel.

The buildings in this shutdown plan which currently have hard-piped LLLW service are listed in Table 7 . The table also lists the estimated discharge to these systems as a result of deactivation activities.

The CAT system in the Isotopes Circle area was constructed in the early 1950s, and most of the piping and collection tanks are singly contained. Current regulations require doubly contained piping and tanks and leak detection systems. The CATs that include WC-10 and WC-2 are under a FFA. The current FFA allows these systems to operate through FY 1994 for the limited purpose of deactivating facilities. This was based upon the original IFDP completion date. A request to extend this date to the end of FY 1998 has been made. A decision is expected before the end of FY 1994. When a facility is deactivated, all inputs to the LLLW system are to be plugged. If LLLW will be generated as a result of routine S\&M after deactivation, provisions for bottling waste will be provided.

\subsubsection{Process waste system}

Process wastewater is water that is slightly or potentially contaminated (e.g., waste from some building sinks, floor drains, and steam condensate from heating coils). Many of the isotopes buildings have drains to the process waste system in addition to the "hot" drains. Process wastewater is collected by underground pipelines and pumped to one of two 350,000-gal tanks (2600 area) in preparation for processing through the PWTP (Building 3544). The wastewater is clarified and processed through an ion-exchange system for removal of ${ }^{90} \mathrm{Sr}$ and ${ }^{137} \mathrm{Cs}$. The waste from the regeneration of the ion-exchange bed is sent to the LLLW system storage tanks.

The effluent from the PWTP is routed to the nonradiological wastewater treatment plant (NRWTP) (Building 3608). At the NRWTP, all waste is sent through dual-media filters, air-stripped for removal of volatile organics, and treated with granular activated carbon to remove nonvolatile organics and mercury. The final treatment tank is used for $\mathrm{pH}$ adjustment. The effluent is monitored prior to discharge to White Oak Creek. The outfall is a National Pollutant Discharge Elimination System-permitted discharge point.

The current plan for the process waste system is to minimize inputs from IFDP facilities. All drains from sinks, hoods, etc., will be plugged. Floor drains will remain open. In the event of a roof leak, this would allow the water to drain without leaving the building. 
Table 7. Liquid low-level waste collection tank service for buildings in the Isotopes Facilities Deactivation Project

\begin{tabular}{llr}
\hline Building & Waste collection tank & $\begin{array}{c}\text { Estimated IFDP } \\
\text { volume } \\
\left(\mathrm{ft}^{3}\right)\end{array}$ \\
\hline $3026-\mathrm{C}$ & WC-170 & 0 \\
3028, general & WC-18 & 500 \\
3028, Cell 7 & WC-10 & 3600 \\
3029 & WC-2 & 0 \\
3030 & WC-10 & 2800 \\
3031 & WC-10 & 900 \\
3033 & WC-10 & 900 \\
$3033-\mathrm{A}$ & WC-10 & 0 \\
$3038-\mathrm{E}$ & WC-10 & 0 \\
$3038-\mathrm{M}$ & Hot drains sealed & 0 \\
$3038-\mathrm{AHF}$ & Hot drains sealed & 0 \\
3047 & WC-2 & 5500 \\
3118 & WC-10 & 22000 \\
& No regular LLLW service; & \\
3517 & by removing plug access to & 0 \\
7025 & WC-10 & 50000 \\
$3026-\mathrm{D}$ & S-223, S-324, and S-523b & 0 \\
& No CAT service & 15000 \\
\hline
\end{tabular}

'Building 3028, Cell 7 has one hot drain routed to WC-2 and two hot drains to WC-10.

'Located in shielded cell; doubly contained pipeline to evaporator facility.

\subsubsection{Solid Waste}

The IFDP facilities generate two types of nonradioactive wastes: landfill material, such as office and packing trash, and hazardous waste. Five types of radioactive waste generated are TRU waste, TRU mixed waste, SLLW, low-level mixed waste, and high-activity waste. High-activity waste must be placed in retrievable storage. In addition, some scrap metal waste will be generated. Estimated waste volumes for each of these categories are listed in Table 8.

\subsubsection{Landfill materials}

This waste consists mainly of trash, non-recyclable waste paper, and other throwaway materials. This waste is transported from ORNL to the sanitary landfill at the Y-12 Plant. 
Table 8. Solid waste volume estimates for deactivation of IFDP facilities $\left(\mathrm{ft}^{3}\right)$

\begin{tabular}{lc} 
Waste type & $\begin{array}{c}\text { Estimated volume } \\
\left(\mathrm{ft}^{3}\right)\end{array}$ \\
\hline Landfill material & 260 \\
Hazardous material & 267 \\
Low-level solid & 19,509 \\
Low-level mixed solid & 688 \\
Transuranic & 85 \\
Mixed TRU & 40 \\
High activity & 176 \\
Scrap metal & 235 \\
\hline
\end{tabular}

\subsubsection{Hazardous waste}

Hazardous waste generated in IFDP facilities generally consists of fluorescent lamp ballasts, expired chemicals, solvent-wet rags, aerosol cans, waste oils, residual paint, asbestos insulation, light bulbs, florescent light tubes, and chemically contaminated equipment.

\subsubsection{Low-level solid waste}

SLLW generated in IFDP facilities is the largest quantity of waste materials generated. This material includes suspect waste which, at ORNL, is handled in the same manner as SLLW. The waste consists of blotter paper, wipes, cheesecloth, small laboratory equipment, glass bottles used in radioactive work and/or cells, plastics, and paper which are contaminated with beta/gamma-emitting radioactive materials. Low-level mixed solid wastes are SLLW which are co-contaminated with hazardous waste.

\subsubsection{Transuranic waste}

TRU waste is generally the same type of waste materials as SLLW with the exception that it is contaminated with low levels of alpha-bearing TRU materials. Mixed TRU wastes are hazardous waste materials which are co-contaminated with TRU radioactive materials.

\subsubsection{High-activity waste}

High-activity wastes are those non-TRU wastes which are of an activity level that they cannot be disposed of as SLLW. They must be packaged and placed in a shielded retrievable storage facility. 


\subsubsection{Waste Minimization}

Waste minimization programs have been implemented in IFDP facilities. The following are waste minimization objectives for deactivation:

- avoid generating waste,

- minimize what is generated,

- recycle what is minimized, and

- treat what cannot be recycled.

These objectives are applied sequentially to the work.

Practical waste minimization efforts include eliminating characteristic hazardous waste, segregating wastes into compactable categories, compacting solid waste, and concentrating diluted waste. Key project waste minimization activities are described in the following sections.

\subsubsection{Liquid effluent minimization}

LLLW will be generated during deactivation primarily from cleanup activities, including flushing hot cells and glove boxes, removing potential airborne contamination, and removing transferable contamination in secondary containment areas. Volumes will be minimized by characterizing contaminants before and after flushing to ensure proper selection of cleaning agents and to determine when additional flushes are of little value. Alternate dry cleaning techniques (strippable coatings, ice blasting, etc.) will be evaluated for each task and will be used where practical.

\subsubsection{Solid waste minimization}

Deactivation activities will generate increased volumes of solid waste.

\subsection{Hazardous waste minimization}

Minimization of hazardous waste will be effected by the careful planning of work that generates this type of waste. Tasks requiring the use of hazardous chemicals will be planned so that minimum quantities are used and the smallest possible quantities ordered. Accurate inventories of these materials are kept so additional materials are not ordered when supplies are available. Asbestos abatement will be minimized. Asbestos will not be removed for the sole purpose of removing asbestos. It shall only be removed when it is required for completion of a deactivation task or if it is damaged and friable.

\subsection{Radioactive waste minimization}

Solid waste volumes will be minimized by incorporating the waste minimization objectives in the planning phase by segregating waste by type to prevent category crossover, and by using waste compaction and size reduction to reduce void space in the waste packages. 
The generation of solid waste at IFDP facilities will be eliminated after completion of the project, except for the small amounts created by routine S\&M activities.

\subsection{NATIONAL ENVIRONMENTAL POLICY ACT DOCUMENTATION}

The original Isotopes Facilities Shutdown Program (IFSP) was to be a 4-year program beginning in FY 1991 and ending in FY 1994. Activities in the first 2 years were to be limited to basic S\&M of facilities, upgrading of facility safety documentation, detailed planning for the shutdown activities to be conducted in FY 1993-94, and obtaining the required NEPA documentation for planned activities. An internal ORNL review of the initial IFSP plans led to a determination that basic S\&M of facilities was an ongoing activity and could continue without additional NEPA consideration. However, the planned consolidation of isotopes inventory and the planned deactivation of facilities required further consideration. In February 1991, an Action Description Memorandum (ADM), which outlined the activities involved in the inventory consolidation, was prepared and transmitted to DOE-HQ for NEPA review. From further NEPA consideration, in July 1991, a Categorical Exclusion (CX) was granted for the inventory consolidation. The inventory consolidation effort began in August 1991.

In August 1991, an ADM describing the plans and activities for deactivation of facilities was prepared and transmitted to DOE-HQ for NEPA review. In October 1991, DOE-HQ directed the IFSP to prepare an Environmental Assessment (EA) for the planned shutdown activities. A predecisional draft EA was prepared and transmitted to DOE. The document has been through four reviews, comments, and a revision cycle. The last set of comments was made by the DOE-HQ Office of General Council and was received in May 1993. The document was revised and returned to DOE in September 1993.

In August 1993, the IFSP was presented with an opportunity to dispose of its inventory of ${ }^{3} \mathrm{H}$-filled RL lights. DOE had negotiated a contract with a private company to purchase DOE's entire inventory of RL lights including those at ORNL. This was viewed as the last chance to remove the lights from ORNL. All possibilities of transferring the RL lights to another DOE site for either recovery or long-term storage had been exhausted. ORNL has no facility for recovery of the tritium or any other facility in which to store the RL lights. It was not clear if additional NEPA consideration was needed for the transfer of the lights; so to be conservative, an ADM was prepared and transmitted to DOE. In December 1993, DOE granted a CX for the transfer of the RL lights. Preparations for transfer began in January 1994, and the first transfer was made in May 1994. The last of the RL lights will be removed in FY 1995.

\subsection{ENVIRONMENT, SAFETY, AND HEALTH}

ORNL ER Program policy is to provide a safe and healthful workplace for all employees, subcontractors, DOE prime contractors, and visitors, and to protect the environment. The accomplishment of this policy at ORNL is guided by the Health 
and Safety Plan for the Environmental Restoration Program at Oak Ridge National Laboratory, ORNL/ER-226.

The ORNL ER Program health and safety plan follows the format recommended by the EPA for remedial investigation and feasibility studies, as well as 29 CFR 1910.120 and DOE EM-40 guidelines for preparing documentation for performing tasks on hazardous waste sites, treatment, storage, and disposal facilities, and for responding to emergencies on hazard waste sites. The health and safety plan is also applicable to activities that are not considered to be performed on the Hazardous Waste Operations and Emergency Response (HAZWOPER) sites.

Activities sponsored by the ORNL ER Program may consist of, but are not limited to remedial action; construction; S\&M; D\&D; environmental sampling; environmental radiological surveys; well installation; well plugging and abandonment; geophysical surveys and mapping; technology development and testing; underground storage tank sampling, removal, or closure; liquid transfer from process holding tanks; and off-site activities.

Site-specific health and safety plans (SSHASPs) will be prepared on a projectspecific basis to address in greater detail the hazards and controls associated with particular tasks. The SSHASP shall address all site-specific information including, but not limited to, the following: work site location, description of each task, work plan for accomplishing each task, anticipated hazards to health and safety, prescribed methods for controlling hazards, monitoring requirements, personal protective equipment requirements, sanitation, decontamination, training and medical requirements, and emergency information.

An SSHASP shall be developed for ORNL ER projects involving activities on sites that fall under the HAZWOPER Program. An SSHASP or an approved (by ER ES\&H Manager) equivalent document shall also be required for other activities that do not fall under the requirements of the HAZWOPER Program but may present hazardous or unsafe conditions for workers or the environment.

\subsection{DOCUMENTATION AND RECORDS}

Data forms, logbooks, and certificates of analysis form part of the documentation pool required for providing objective evidence of quality. All documentation must be legible, retrievable, and in such a format as to be defensible in the ability to accurately reconstruct the performance of work.

Documentation and related objective evidence of quality shall consist of:

- the work plan;

- the QA plan;

- the health and safety plan (when required);

- facility maintenance and calibration logbooks;

- facility logbooks (to be maintained by the Facility Supervisor or representative);

- facility operating procedures; and 
- training files.

All documentation must be completed in waterproof black ink, and corrections must be marked through with a single line, dated, and initialed. Handwritten documents must be legible. The information to be provided for each of these documents is described in ESP-102, "Field Quality Control."

\subsubsection{Field Documentation Forms}

Field investigation activities will be documented primarily on field documentation forms. The forms referenced in the procedures provided in Appendix A will be used during this investigation. Any information pertinent to the current field activity or field condition that is not requested on the field documentation form should be entered in the "Comments" section of the form and in the field logbook. The forms used at the site will be numbered sequentially.

All completed field documentation forms will be transferred to a hard cover, three-ring notebook for temporary storage upon completion. In addition, any charts, oversized pages, and other printed material (e.g., lists of sample times) pertinent to current field activities will be securely attached to the corresponding field documentation form and contained in the notebook. The number of the corresponding field documentation form must be written somewhere on the attached material and contained in the notebook.

\subsubsection{Quality Records}

On a weekly basis, the completed forms will be taken from the notebook and entered into the project's data-management data base. As appropriate during the life of the project, completed field forms and related quality-affecting documentation will be copied on a weekly basis and transferred to the CDM Federal Programs Corporation in Oak Ridge, Tennessee, in accordance with dual-storage requirements for quality records.

Quality records will be authenticated as such by project management in consultation with the project QA coordinator. Quality records will include project documentation such as logbooks, field forms, and calibration records, as identified by this QA project plan.

All records generated on this project are subject to the requirements of ESS-QA-17.0, "Quality Assurance Records," and any associated requirements pertaining to the Administrative Record (AR) maintained by the ER Document Management Center (DMC). The Energy Systems AR staff will initiate and designate documents for inclusion in the AR files and ARs and submit these documents to the ER-DMC for retention. 
Appendix A

DESCRIPTION AND HISTORY OF FACILITIES 
-

- 
This appendix presents information about the isotopes facilities that are to be (1) maintained in a safe condition under the existing maintenance and surveillance plan and (2) prepared for acceptance and transfer into the Surplus Facilities Management Program.

The site and the supporting Oak Ridge National Laboratory operational services that interface with the facilities are described briefly in Sect. A.1. A description of the individual facilities by building is presented in Sect. A.2. 
-

-

- 


\section{A.1. SITE DESCRIPTION}

Most of the facilities in the Isotopes Facilities Deactivation Project (IFDP) are located at the central Oak Ridge National Laboratory (ORNL) complex in Bethel Valley. ORNL is sited on the U.S. Department of Energy (DOE) Oak Ridge Reservation approximately $13 \mathrm{~km}$ ( 8 miles) from the population center of the city of Oak Ridge. The locations of isotopes areas within ORNL are shown in Fig. A.1. Most of the facilities in the IFDP are located in close proximity to the main administrative building $(4500 \mathrm{~N})$ and research facilities. One facility, Building 7025, is located in the 7000 area about $2.2 \mathrm{~km}$ (1.4 miles) east of the main ORNL complex.

The Oak Ridge Reservation lies in an area between two mountain ranges. The Cumberlands rise to $910 \mathrm{~m}(3000 \mathrm{ft})$ or more $16 \mathrm{~km}$ (10 miles) northwest, while $113 \mathrm{~km}$ (70 miles) to the southeast the Great Smoky Mountains reach an altitude of some $2010 \mathrm{~m}$ (6600 ft). The area is part of the Valley and Ridge physiographic province. The reservation is a wooded complex dominated by a series of ridges and valleys tending northeast/southeast. It is bounded on three sides by the Clinch River, which is a tributary of the Tennessee River and is part of the water system controlled by the Tennessee Valley Authority.

The mountains on the east and the Cumberland Plateau on the west have a protecting and moderating influence on the region's climate. As a result, it is milder than the more continental climates found just to the west on the Plateau or on the eastern side of the Smoky Mountains. The prevailing winds follow the general topographic trend of the ridges: daytime, up-valley winds come from the southwest; nighttime, down-valley winds come from the northeast. The Smoky Mountains to the southeast provide general sheltering; severe storms such as tornadoes or highvelocity windstorms are rare. Similarly, the mountains divert hot, southerly winds that develop along the southern Atlantic coast. The average monthly temperature ranges from about $3.5^{\circ} \mathrm{C}\left(38^{\circ} \mathrm{F}\right)$ in winter to $25^{\circ} \mathrm{C}\left(77^{\circ} \mathrm{F}\right)$ in summer. The 38-year annual average precipitation (water equivalent) is $1.36 \mathrm{~m}$ (53.5 in.), including approximately $0.25 \mathrm{~m}$ (9.8 in.) of snowfall, with monthly precipitation peaking in January and February.

The population (1980 census) of the city of Oak Ridge is 28,000 . Except for the city of Oak Ridge, the land near the Oak Ridge Reservation is predominantly rural, used largely for residences, small farms, and cattle pasture. Knoxville, the major metropolitan area nearest Oak Ridge, is located about $40 \mathrm{~km}$ ( 25 miles) to the east and has a population of approximately 183,000 .

The central ORNL site is located in Bethel Valley between Chestnut Ridge on the north and Haw Ridge. Although the valley floor is highly developed within the central site area, the surrounding terrain is wooded. White Oak Creek passes to the south of the developed area and leaves the valley through a gap in Haw Ridge into Melton Valley. Experimental programs that require isolation are located at satellite sites in Melton Valley. 


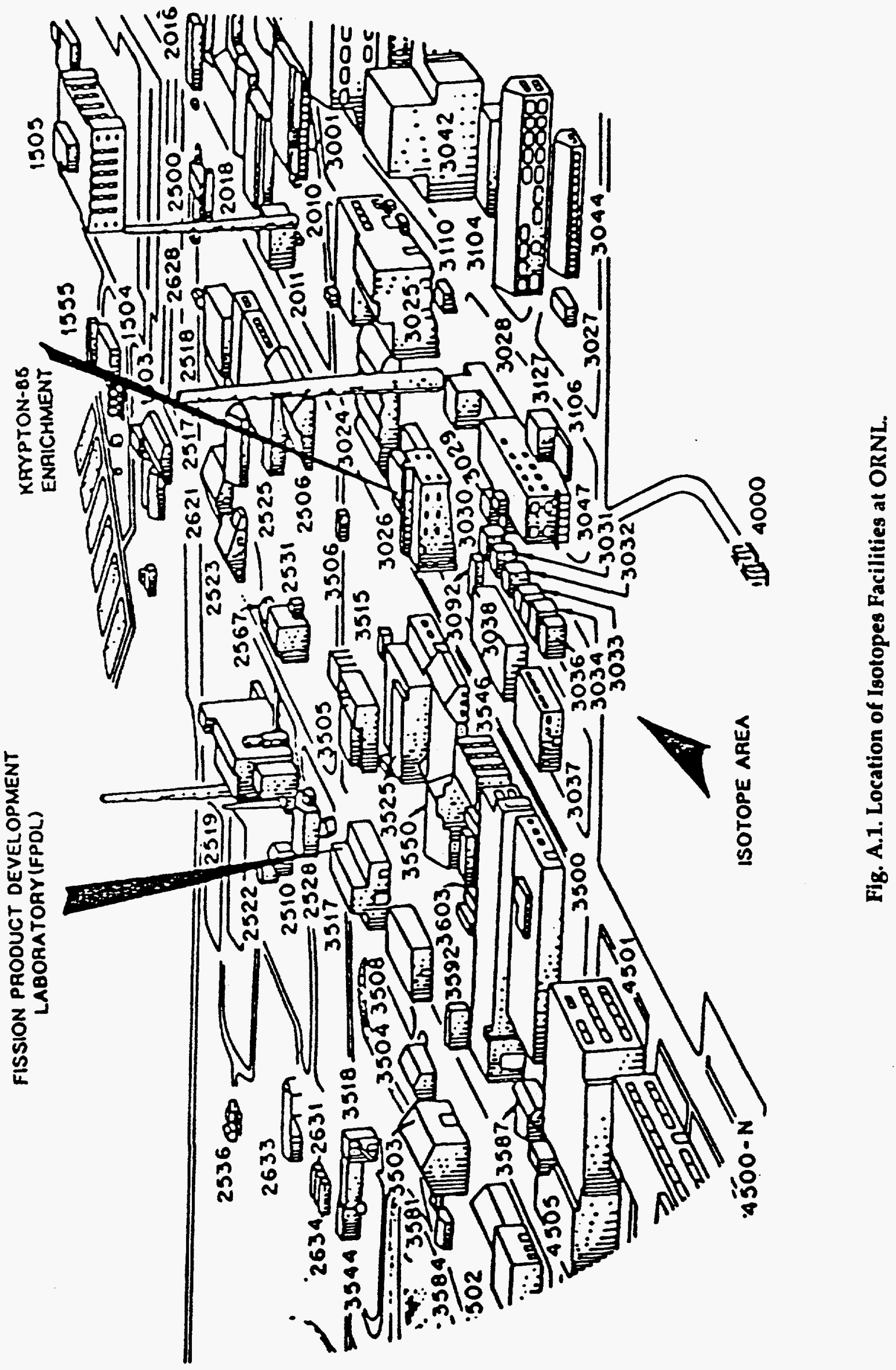




\section{A-7}

One of the buildings in this plan (Building 7025) lies at the extreme eastern end of the developed area in Bethel Valley. Most of the 7000 area consists of shops (e.g., maintenance) and stores receiving and warehouses. Building 7025 is located at the extreme eastern limit of this area. The only utilities supplied are water and electricity.

Building 9204-3 is located in the south-central part of the developed area the Y-12 Plant. The Y-12 complex is situated in Bear Creek Valley adjacent to the city of Oak Ridge. Most of the Y-12 facilities lie on the valley floor between Pine Ridge on the north and Chestnut Ridge on the south. 
$\bullet$

-

- 


\section{A.2. DESCRIPTION OF FACILITIES}

\section{A.2.1 BUILDING 3026-C-KRYPTON-85 ENRICHMENT FACILITY}

\section{A.2.1.1 Description}

Building 3026-C is a two-story wooden structure (22 ft high) located on Central Avenue to the west of the Isotopes Circle facilities. The building layout is shown in Fig. A.2. Ancillary facilities consist of offices, low- and high-level radioactivity laboratories, and a counting room. An instrument shop, operated by the Instrumentation and Controls (I\&C) Division, is located in the southwest comer of Building $3026-C$ but is not related to facility operations. The facility shares a common wall and utilities with the adjacent Building 3026-D, Segmenting Hot Cell Facility. The two facilities are operationally independent. All areas of the building are protected by automatic fire sprinklers monitored at the ORNL Fire Department.

A tritium facility at the northwest corner of Building 3026-C is constructed of reinforced concrete. The small laboratories, counting room, and cell banks are also of reinforced concrete. With the exception of these concrete structures, the partitions and ceilings throughout Building 3026- $\mathrm{C}$ are wooden.

\section{A.2.1.1.1 Cells}

The two-story structure (i.e., high bay area) of Building 3026-C houses two banks of four hot cells each. These cells are constructed of reinforced concrete $2 \mathrm{ft}$ thick (top, sides, and partitions) with a 4 - by 6 -ft floor space for each cell. The inside height of Bank 1 (Cell 4) and Bank 2 (Cells 2 and 4) is $10 \mathrm{ft}$, and the height of each of the other cells is $8 \mathrm{ft}$. The cells of Bank 1 on the west side are equipped with $\mathrm{Zn}$-Br-filled viewing windows and master-slave manipulators. Access to each cell in Bank 2 is through a 2- by 2-ft doorway shielded by 7 -in.-thick steel doors. Attached to the north side of Bank 2 (Cell 3) is a 3- by 6-ft by 7-ft-high structure, constructed of 2-in.-thick upper and lower hinged steel doors on the west side. The east-side doorways of Bank 2 cells are opened during part of the normal krypton diffusion operation; the shielding during this time consists of a 2-in.-thick lead glass viewing window permanently mounted in 2 in. of lead brick. Overhead access to Cells 2 and 4 of Bank 2 is through concrete roof blocks, which are removed for in-cell maintenance. There are no radioactive liquids generated in the thermal diffusion process. Floor drains in the cells discharge to the liquid low-level waste (LLLW) system, which is out of service.

On the west side of Bank 2, a shielded sampling station is equipped with a vacuum pump venting to cell ventilation, a sampling manifold, a cold trap, in-line rupture discs, and a surge tank.

Contamination in Buildings 3026-C is controlled by the building ventilation system, which moves air from areas of lesser contamination potential to areas of higher potential and exhausts the air through the cell ventilation system. Thus, the ventilation air in the facility flows from the operating room through the cell in- 


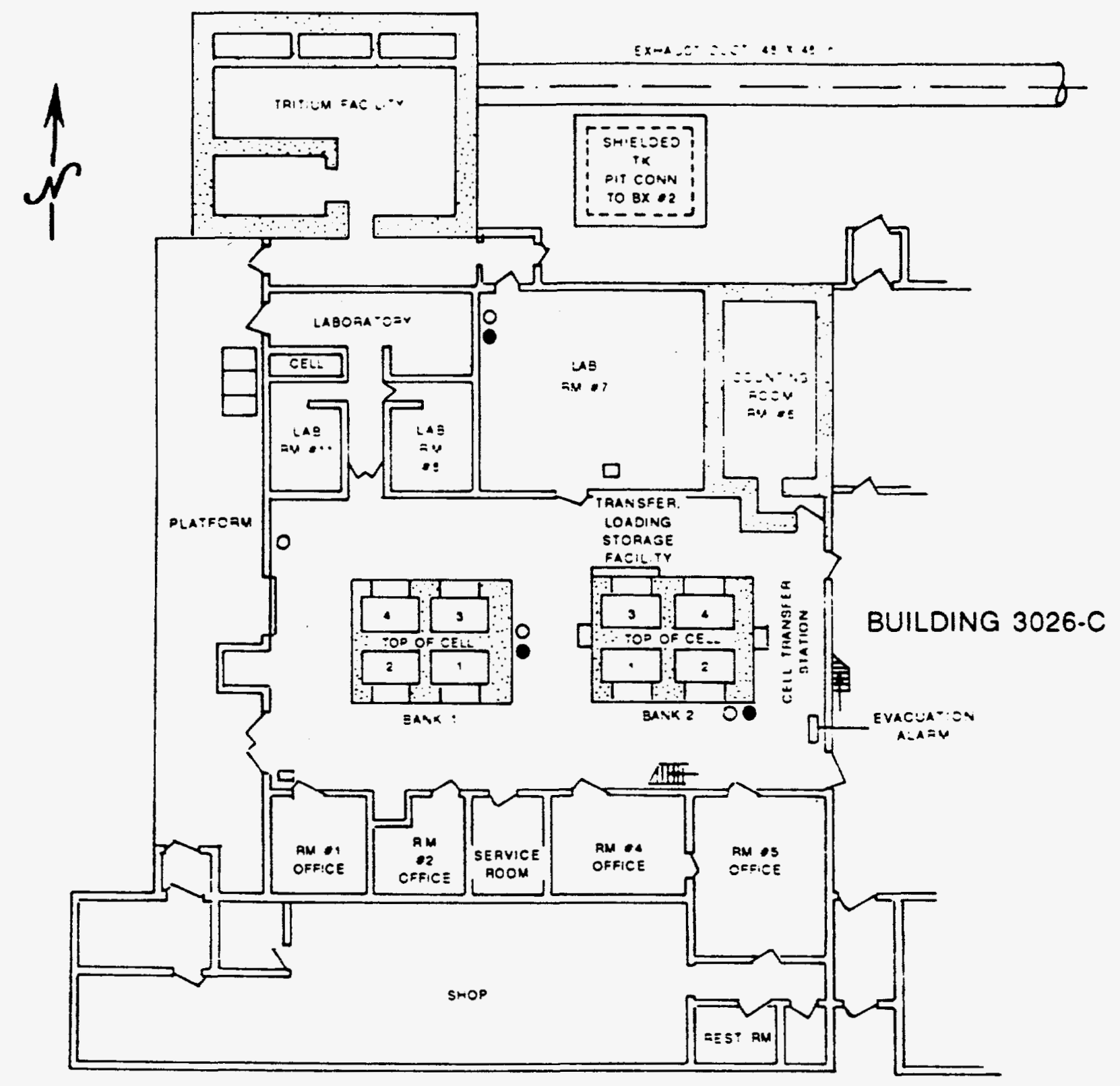

FIRST FLOOR BUILDING 3026-C

Fig. A.2. Floor plan of Building 3026-C. 
leakage openings into the cells from which it is discharged to the building cell ventilation header that connects to the 3039 stack system. To ensure inleakage to the cells, the interiors are maintained at 0.75 to 1.0 in w.g. negative pressure relative to the operating area. The cells and transfer and sampling stations are monitored continuously with preset differential pressure gauges that activate a local alarm and telemeter a signal to the Waste Operations Control Center (WOCC) (Building 3130). There are no backup monitors or gauges on this component of the facility.

Should ventilation disruption occur during off-operating shifts, the patrol operator on duty in the WOCC will notify assigned facility operating personnel. The 3039 stack system has an alternate ventilating fan and power source in case of mechanical failure of the system in use, and a diesel generator provides emergency power should an outage occur.

\section{A.2.1.1.2 Laboratories}

Ventilation of the three small laboratories in the Room 11 complex is provided by hood exhausts connected to the Building 3026-C ventilation duct to the 3039 stack. The duct from one of the hot hoods is provided with a high-efficiency particulate air (HEPA) filter. All laboratories are used for low-level radioactive work. Another hood exhaust is located in the northwest corner of the main 3026-C cell operating area. There is lead shielding on the south wall of Laboratory 11.

\section{A.2.1.1.3 Tritium storage}

Tritium is stored in the concrete tritium laboratory room on the north side of the building and in a hood in Room 7. A doorway on the south side of the concrete room is closed only by a steel grate, which is kept locked to control access when the laboratory is not attended. The laboratory provides storage space for tritium light sources. Unassembled tritium-filled tubes are also stored in a hood in Room 7.

Air flows into the tritium facility through the open door at the south side of the laboratory and through a ceiling duct. Air is exhausted to the 3039 cell ventilation system through a hood in the small room on the south wall and through vents on the north and west walls. The flow rate is approximately $1500 \mathrm{cfm}$. Air flows through the Room 7 hood at the rate of $300 \mathrm{cfm}$; it enters Room 7 through a roughing filter in the door, which leads to the operating area.

\section{A.2.1.1.4 Instrument shop}

The shop located in the southeast comer of Building 3026-C is unrelated to the operations of either 3026-C or 3026-D. It is separated from other activities in the buildings by at least two doors and can be entered or exited without entering the operating areas.

\section{A.2.1.2 History}

The building, which was constructed in 1943, was used primarily for about 5 years to develop methods of isolating fission products. After the war, the effort shifted to 
processing radioisotopes for research and medical purposes. The waste from processing irradiated reactor fuel elements for uranium and plutonium recovery in Building 3019 was piped directly to Building 3026-C. At Building 3026-C, it was processed to isolate short-lived isotopes. Some of the isotopes recovered were $129 \mathrm{~L}$, $1311,79 \mathrm{Se}, 107 \mathrm{Pd}$, and $147 \mathrm{Pm}$. The feed stream from Building 3019 would have contained fission products such as ${ }^{137} \mathrm{C}$ and $90 \mathrm{Sr}$ as well as alpha-emitting actinides. The commercial isotopes program started in Building 3026-C.

The krypton system was installed in the east cell bank (Cell Bank 2) in the mid 1960 s and is still functional but has not operated in over 2 years. Because of the long operational period, the system is highly contaminated with krypton, which is embedded in the organic gasketing material of the equipment.

By the early to mid 1960s the two front cells of the west cell bank (Bank 1) were being used by the Metals and Ceramics (M\&C) Division. It is thought that irradiated reactor fuel elements were segmented in these cells. Cells were also originally used for source safety testing and, more recently, have been used for hot metallographic work. They have now been shut down.

Since 1974, Cells 3 and 4 of Bank 1 have been used exclusively for nuclear medicine research.

\section{A.2.1.3 General Status}

The krypton sales program operations in Building 3026-C were discontinued in 1991. Krypton loading equipment in Building $3026-\mathrm{C}$ is still functional and will be used in the final disposal of all residual $85 \mathrm{Kr}$ as part of the IFDP planned activity. The Health Sciences Research Division (HSRD) now uses only Cell 4 in Bank 1 (west), the Laboratory 11 complex, and the counting room for nuclear medicine research. The I\&C Division operates a shop in the southwest corner of the building in which they repair and maintain monitoring equipment. I\&C presently occupies offices in Room 5. The baseline assumption for the IFDP is that all activities will be terminated in Building 3026-C by September 30, 1994.

The general status of the building is summarized in Table A.1.

\section{A.2.2 BUILDING 3026-D-SEGMENTING HOT CELL FACILITY}

\section{A.2.2.1 Description}

Building 3026-D, east of and adjacent to $3026-\mathrm{C}$, is a three-story wooden structure. The principal structure within the building is a two-story, 5-ft-thick concrete cell block which is divided into two connecting radioactive material handling cells (hot cells) located in a north-south direction. The west face of the cell block is equipped with manipulators and $\mathrm{Zn}-\mathrm{Br}_{2}$-filled viewing windows. To the west of the cell block, located at floor level is a high-level radioactivity storage facility. This is connected to the south hot cell via a tunnel below the floor for transfer purposes. 
Table A.1. Building 3026-C-general status of facility

Facility/area

Comments

Building

Type

Wood.

Roof and exterior walls

Poor condition.

Building ventilation

Containment is by hot cells and hoods; no secondary containment. The building is not sealed; no air locks. Building ventilation air moves from the operating area through cell inleakage openings or hoods and is discharged to the 3039 cell ventilation system and stack; no HEPA filters. Cell Bank 2 handles only radioactive gas (krypton). May be roughing filters on two cells in cell Bank 1, but this could not be confirmed.

Liquid waste system

Cell floor drains and hood "hot" sinks drain to tanks $W-17$ and $W-18$.

Monitoring

Other comments

Cells and transfer stations continuously monitored with preset differential pressure gauges that activate local alarms and telemeter a signal to the WOCC (Building 3130).

In early days, facilities were used to process fission products, uranium, and plutonium and to segment irradiated reactor fuel elements. Technicium-99 is the most predominant residual contamination from past radioisotope processing. May also find residual contamination (e.g., alpha, ${ }^{137} \mathrm{Cs}$ ).

Facilities, utilities, and services are in fair condition; however, everything is currently operational.

Asbestos insulation: some sound, some not sound.

Relatively large quantities of contaminated lead shielding. 
Table A.1 (continued)

Facility/area

Comments

\section{Cell Bank 1 (west)}

Cells 1 and 2

No operations. Used by ORNL M\&C Division for hot metallographic work. It is thought that reactor fuel elements were segmented in these cells; cells are contaminated with ${ }^{60} \mathrm{Co}$ and ${ }^{137} \mathrm{Cs}$.

Cells 3 and 4

Used for nuclear medicine research; short-lived radioisotopes.

Cell Bank 2 (krypton)

Operating facility; krypton (gas) inventory stored in Cells 1 and 3. After deactivation and removal of the inventory, equipment will be contaminated with krypton; thermal diffusion system in Cells 2 and 4 will be highly contaminated; slow release of residual krypton embedded in organic gasketing material to cell ventilation air.

\section{Laboratories}

Tritium facility and Laboratory 7

Laboratory 11 complex

Large inventory of tritium (gas) contained in glass tubes from the tritium radioluminescent light program are stored in the tritium facility and in a hood in Laboratory $7 ; 74$ tubes that originally contained about $7000 \mathrm{Ci}$ of tritium are known to have been leakers.

Tritium-contaminated equipment.

"Hot" drain in the Room 7 hood and in the hood in the small room on the south wall of the main tritium room.

Used by nuclear medicine for research and development work on radioisotopic tracers; HEPA filters on hoods.

HEPA filter on exhaust from one hood. 
The building also houses a Chemical Separation Laboratory in addition to the Segmenting Hot Cells Facility. Historically, the Chemical Separations Laboratory has served as a facility for the production of 32P and 131I; separation of numerous fission products; isolation of ${ }^{99} \mathrm{~T}, 147 \mathrm{Pm}$, and ${ }^{237} \mathrm{~Np}$; and the isolation of $135 \mathrm{Xn}$ for neutron cross-section determination. The Segmenting Hot Cells Facility was originally used to isolate large quantities of fission-produced $140 \mathrm{Ba}$ for criticality testing purposes. The cells in the Segmenting Hot Cells Facility have been greatly modified since the discontinuance of the earlier $140 \mathrm{Ba}$ process. They now provide facilities for the segmenting, examination, and assembly of irradiated metallurgical specimens.

Contamination in Building 3026-D is controlled by the design of the building ventilation system, which moves air within the building operating area from areas of lesser contamination potential to areas of higher potential and exhausts the air through the cell ventilation system. Established procedures in compliance with the ORNL Health Physics Manual are followed for operations in the facility.

\section{A.2.2.2 Status}

There are no ongoing operations in Building 3026-D other than the storage of irradiated metal specimens. The general status of the facility is shown in Table A.2.

\section{A.2.3 BUILDING 3028-ALPHA POWDER FACILITY}

\section{A.2.3.1 Description}

Building 3028 was constructed to separate 131 I and later modified to separate ${ }^{133 X e}$ and other short-lived fission products from uranium-aluminum targets. The building was later expanded to include curium processing cells. It is a steel-frame structure covered by metal siding and is located in the northwest area of Isotopes Circle, directly west of Building 3047.

The building has a four-story central section with one-story cell operating areas on the east and west sides (Fig. A.3). The first floor covers $4000 \mathrm{ft}^{2}$, and the total volume of free space is $80,000 \mathrm{ft}^{3}$. Alpha powder handling operations were conducted on the east side in Cells $1,2,3,4$, and 5 . On the west side, $147 \mathrm{Pm}$ processing was conducted in Cell 6. Iodine-131 and other short-lived fission products operations were conducted in Cell 7 and the ${ }^{133} \mathrm{Xe}$ recovery and purification cubicle. After shutdown of the 1311 production capability, various mechanical and chemical processes were conducted in Cell 7 to produce radioisotopes upon customer demand. The fourth floor has been used only for storage in recent years.

Cells 1, 2, 3, and 4 are manipulator cells with one observation window each. They have steel tank walls and tops containing $2 \mathrm{ft}$ of water for neutron shielding. The steel tanks are bolted together in series and are interconnected with an air-lock system. Each cell is lined with stainless steel, and all penetrations are seal-welded. 
Table A.2. Building 3026-D-general status of facility

Facility/area

Comments

Building

Type

Roof and exterior walls

Building ventilation

Liquid waste system

Monitoring

Other comments

Chemical Separations Laboratory

\section{Hot Cells}

Cell A

Cell B
Wood.

Poor condition.

Containment is by hot cells and hoods; no secondary containment. The building is not sealed; no air locks. Building ventilation air moves from the operating area through cell inleakage openings or hoods and is discharged to the 3039 cell ventilation system and stack through one stage of HEPA filters in the cell and one stage at the stack.

Cell floor drains and hood "hot" sinks drain to tanks W-16.

Cells and transfer stations are continuously monitored with preset differential pressure gauges that activate local alarms and telemeter a signal to the WOCC (Building 3130).

Facilities, utilities, and services are in fair condition; however, everything is currently operational.

Asbestos insulation: some sound, some not sound.

Numerous areas of fixed contamination throughout the facility.

No operations. General disrepair.

No operations.

$\mathrm{Zn}-\mathrm{Br}$ windows are leaking.

No operations, used for storage of $4000 \mathrm{lb}$ of irradiated steel specimens containing an estimated $300 \mathrm{Ci}$ of $60 \mathrm{Co}$. 


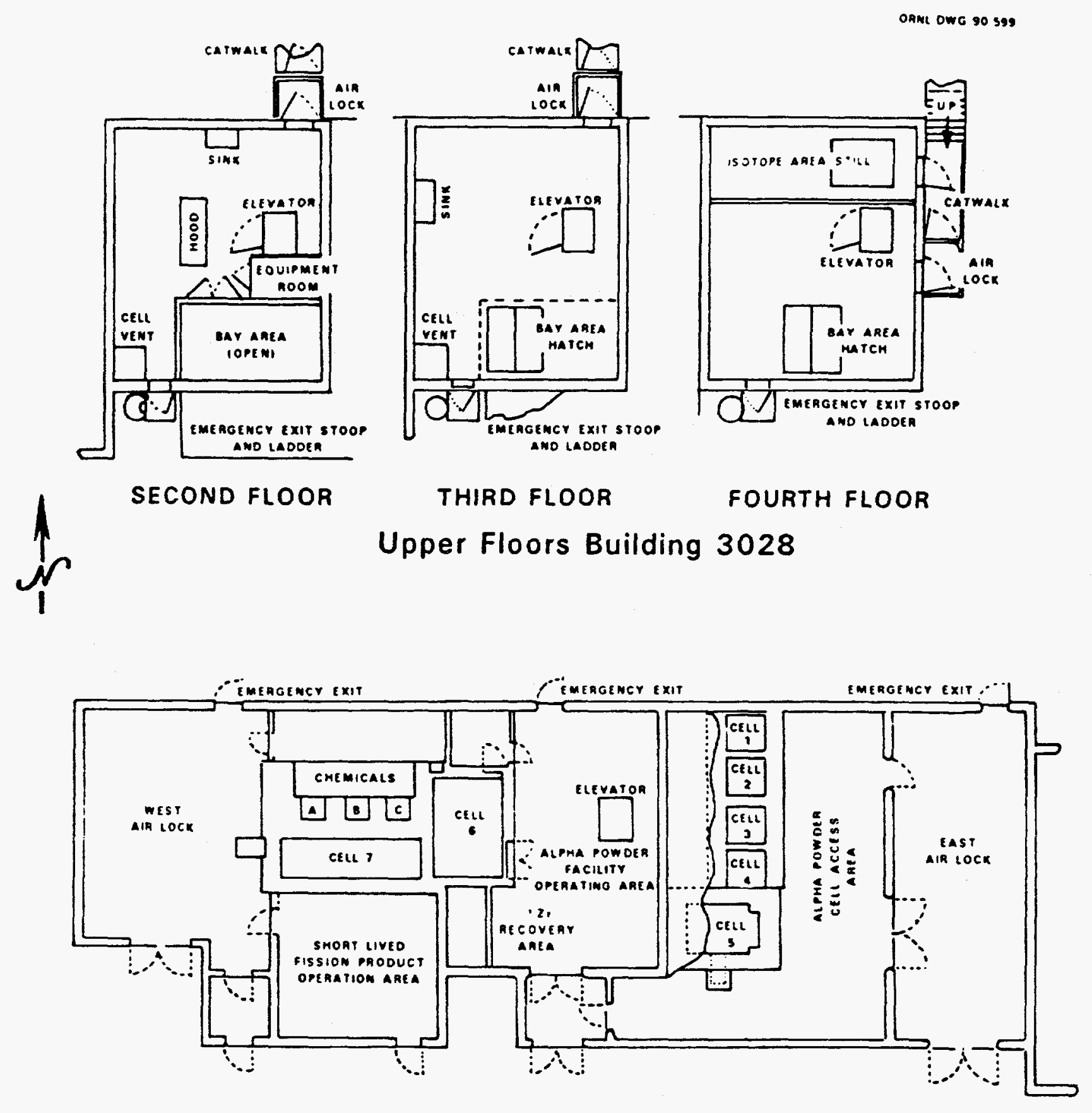

First Floor Building 3028

Fig. A.3. Floor plan of Building 3028-Alpha Powder Facility and Short-Lived Fission Product Facility. 
Cells 2 and 3 have back windows with glove ports. Cell 5 is a manipulator cell with the following features: a stainless-steel operating pan; 9.5-in. armored steel plate and 1-ft concrete north, south, and west walls and top; a small armored access port in the south wall and the viewing window in the west wall; a pass-through air lock to Cell 4; and a 3-ft east wall with a water-filled, armored-steel, rear-access door. Cell 6 has 7.5-ft-high stacked barytes walls, steel-clad lead access doors in the north and east walls, and lead shielding along the east wall. Cell 7 is a manipulator cell with the following features: 3 - $\mathrm{ft}$, high-density concrete south and west walls; a l-ft east wall lined with 4-in. lead; north wall consisting of 2 -ft concrete partition; top consisting of a stack of five sheets of 3.5-in. armor-plate steel; a roof plug access; and an armored, lead-lined access port in the west wall.

Cell windows for 1, 2, 3, and 4 are water-filled, safety-plate glass accessed from the exterior (cold side). Cell 5 has an oil-filled window that is accessed from the interior (hot side). Cell 6 is a process cell and has no window. Cell 7 has one mineral oil-filled, leaded-glass window that is accessed from the cold side. Replacement of the other window was started but was not finished due to lack of funding, and it has only a single pane of glass.

The operating cells provide the primary containment of radioactive materials, with secondary containment being the building itself. The cells operate at a minimum of -0.3 in. (normally 1 to 2 in. negative) w.g. to maintain containment. The building's outer surface is "cocooned" with polyurethane foam. All normal entries have air locks for lift trucks and personnel access and gasketed doors to minimize inleakage.

The building interior operates under containment (at least -0.3 in. w.g.) at all times. Building ventilation passes through a network of exhaust ducts to a series of roughing and HEPA filters in an unshielded filter house on the roof. The west end discharges to the isotopes area cell ventilation system and the 3039 stack. The east end [the Alpha Handling Facility (AHF)] is discharged to a short stack on the roof.

The exhaust from Cells 5, 6, and 7 is double-HEPA filtered and discharged to the isotopes area cell ventilation system and 3039 stack.

\section{A.2.3.2 History}

The building was constructed about 1950 as part of the Isotopes Program. It originally housed the 131I processing facility (now the Short-Lived Fission Product Cells) and the separation facility (a four-story ion-exchange column) for 147Pm. The 131I facility was converted to manipulator cells in the early 1960s and expanded to the Short-Lived Fission Product Facility. The ${ }^{133} \mathrm{Xe}$ facility was added at about that time.

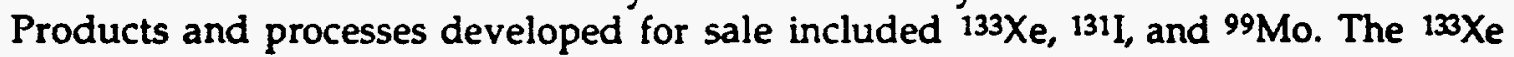
operation continued through 1980, and the Short-Lived Fission Product Program was discontinued in 1985.

The ion-exchange columns were removed in the early 1960s. The upper three floors were converted to target fabrication facilities in the mid to late 1960s. Target fabrication was a full-cost-recovery program at that time. Water-shielded cells were 
installed on the first floor in 1964 for the curium source fabrication program of Space Nuclear Systems. The curium fabrication program was not a full-cost-recovery isotopes program. The curium cells were partially decontaminated in the mid 1980 s and the facility was redesignated as the Alpha Powder Facility, which brought it back into a full-cost-recovery isotopes program. In the late 1970s, the target facility moved to Building 3038 and the upper floors were occupied by Nuclear Medicine Research, which was funded by Energy Research (HSRD). They tumed the laboratory facilities over to the Office of Risk Assessment (HSRD) in 1988. The major contamination in this building is left from the curium processing, the source fabrication work, and the 147Pm processing.

\section{A.2.3.3 General Status}

The general status of Building 3028 is summarized in Table A.3. There are no operations in the building other than those required to maintain compliance with health and safety requirements.

\section{A.2.4 BUILDING 3029-SOURCE DEVELOPMENT LABORATORY}

\section{A.2.4.1 Description}

Building 3029 is located in the west-central area of the Isotopes Circle, southwest of Building 3047. The building is a single-story, steel-frame structure covered by corrugated metal siding. The floor area is $3,000 \mathrm{ft}^{2}$, and the total free-space volume is $33,000 \mathrm{ft}^{3}$. The building layout is shown in Fig. A.4.

The operating area contains four manipulator-type hot cells. Cells 1, 2, and 3 were used to process high-level beta/gamma sources; Cell 4 was used for short-lived materials and ${ }^{192} \mathrm{Ir}$ monitoring. The cell access area contains a $60 \mathrm{Co}$ storage and irradiation area known as the ${ }^{60} \mathrm{Co}$ garden. The ${ }^{60} \mathrm{Co}$ garden has been emptied and is part of the isotopes facilities deactivation. Two laboratory hoods located in the southwest corner of the operating area are used for preparing both elemental $131 I_{2}$ and $\mathrm{CH}_{3}$ 131I. These hoods are equipped for use as glove boxes. There are two small glove boxes in the northeast corner of the cell access area.

Cell 1 and 3 can operate independently or in combination with Cell 2. Cell 2 is dependent on Cell 1 or 3 for transferring materials in or out of the cell. Cells 1 and 3 are lined with stainless steel and have 3-ft barytes concrete walls. Cell 3 also has 2 in. of lead shielding on the operator side. Cell 2 has a 3-ft barytes concrete wall on the operating side, $1 \mathrm{ft}$ of steel on the cell access side, a stainless steel pan, and walls coated with a radiation-resistant sealant. Cell 4 is lined with stainless steel and has 2-ft barytes concrete walls and top.

Cells 1, 2, 3, and 4 have mineral oil-filled, lead-glass windows. Access to windows in Cells 1, 2, and 4 is from the cold side; in Cell 3, it is from the hot side. 
Table A.3. Building 3028-general status of facility

Facility/area

Comments

\section{Building}

Type

Roof and exterior walls

Building containment and ventilation

Liquid waste system

Cask handling
Steel frame with metal siding.

General condition of building exterior is adequate; roof leaks.

Building sealed; air locks; building operates in a "contained" condition of at least 0.30 in. w.g. negative pressure with respect to outside atmosphere.

Meeting building containment is a problem because of the poor condition of the roof; ventilation system on the east wing is run at near-full capacity and is just meeting requirement.

Building ventilation; filter house with double HEPA filtration on roof; west end exhausts to isotope area cell ventilation system and 3039 stack; east end (alpha handling facility) exhausts to local fan and short stack on east end roof.

Cell ventilation: (1) alpha cells, HEPA filtration, exhaust to process off-gas system, and 3039 stack; (2) Cells 5, 6, and 7, HEPA filtration, exhaust to isotope area cell ventilation system and 3039 stack.

Cell floor drains: Cells 1 to 4 drain to intermediate holding tank (W11) which is out-of-service. Other cells drain directly to the LLLW system. Building 3028 drains to tank WC-10, except Cell 7. Cell 7 has one drain to tank WC-2 and two drains to WC-10. There is some question as to whether the Cell 5 drain is connected.

Forklift (9800-1b capacity). 
Table A.3 (continued)

East Air Lock

Alpha Cells Charging Area

Cells

Cells 1-4 (alpha)
Pit below the floor in southeast corner has filters for Building 3047 and part of the filters for Building 3028 process off-gas; pit contained 6 in. of water last time it was opened; floor above pit roped off as radiation zone.

500-gal waste tank that services the alpha cells located in pit under floor. The pump has not been checked in 6 years.

Chilled water unit used to cool floor pans of alpha cells; is contaminated inside.

Area is highly alpha contaminated. All painted surfaces have contamination under them.

Entrance into old cell ventilation duct should be sealed to prevent new ventilation system from pulling contamination from the duct.

Off-gas filters for Cells 1 to 4 are located in ceiling of the cell charging area. Filters cannot be reached safely without scaffolding. Permanent scaffolding is needed for safety (rather than the temporary measures now used).

Highly contaminated with alpha ( $\mathrm{Pu}, \mathrm{Cm})$.

Lighting and electrical services are in poor condition due to radiation damage.

Liquid waste tank (needed for cell wash down) is out of service.

Cell 1: empty.

Cell 2: empty.

Cell 3: contains waste.

Cell 4: contains a welder. 
Table A.3 (continued)

Facility/area

Comments

\section{Cells (continued)}

Cell 5 (alpha and beta/gamma)

Cell 6 (pipe cell)

Cell 7 (short-lived fission products)

Cubicle area

West Air Lock

Second, Third, and Fourth Floors

Fourth Floor
Contaminated with alpha and beta/gamma.

Some question as to whether floor drain is connected to LLLW system.

Highly contaminated with $147 \mathrm{Pm}$. Cell must be entered periodically to change filters.

Relatively clean; entered in 1986 to connect new cell ventilation system; no operation since that time.

West cell window has only one pane of glass. Work started to convert west window to lead glass but stopped due to lack of funding. If off-gas safety system failed, it could pull single pane in, breaking containment.

Filter system was never completed to give testable HEPA filters on Cell 7.

Process off-gas from Cell 7 exhausts through HEPA filters to the area process off-gas system. It is assumed that the scrubber still contains contaminated dried salts.

Contaminated; old equipment still there.

Charcoal filter pit under floor; probably is contaminated; however, short-lived fission products were last processed in 1986 and those would have decayed.

Empty. Second, third, and fourth floors and the elevator shaft have plutonium and $147 \mathrm{Pm}$ contamination under the paint; paint is chipping and peeling.

Roof leaks. 
$\overline{8}$
1
$\vdots$
8
0
$\vdots$
$\vdots$
$z$
$z$
0

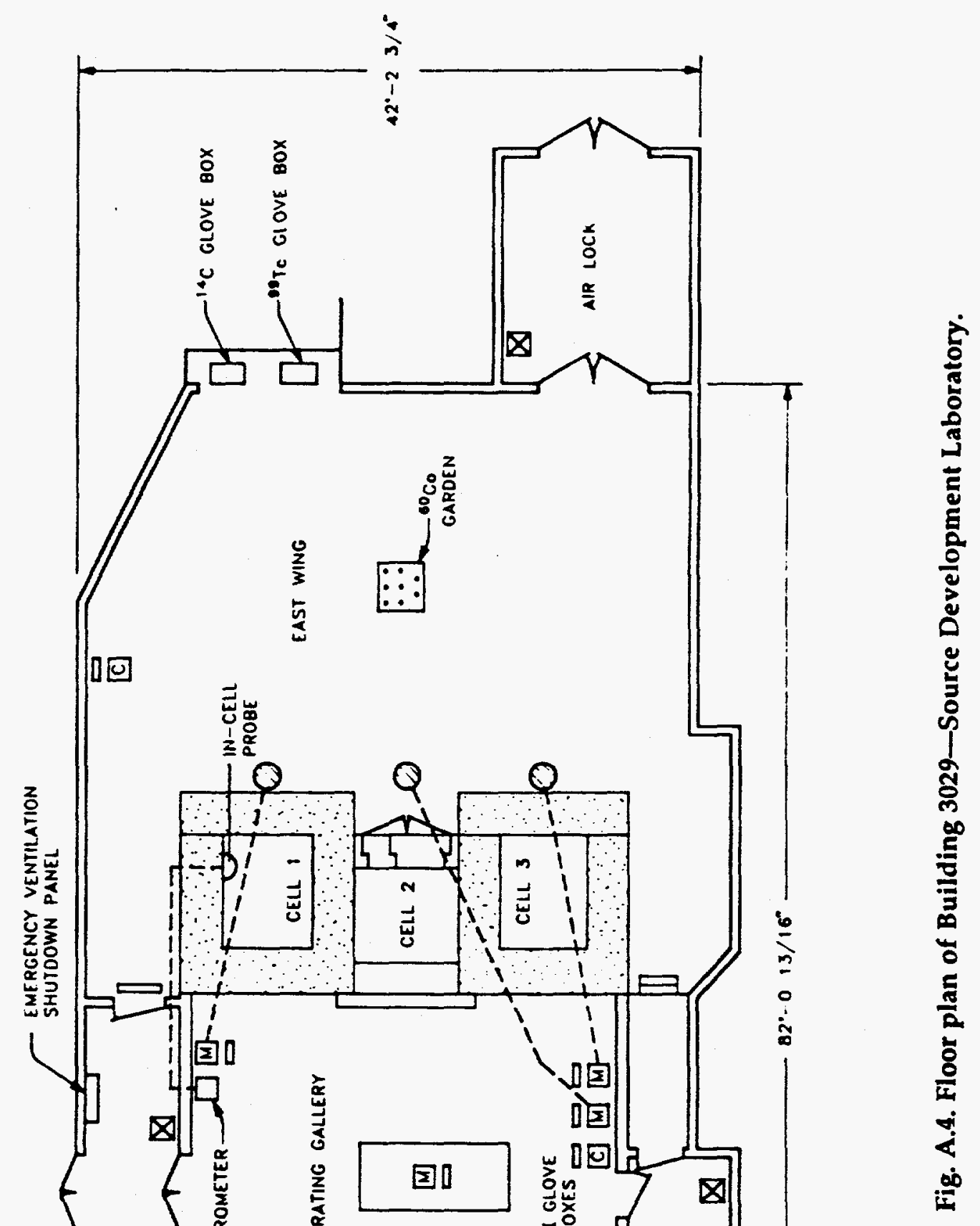


The building's outer surface is sealed for airtightness by cocooning with polyurethane foam. All normal entries have air locks for lift trucks and personnel access and have gasketed doors to minimize inleakage. Building ventilation is provided by a roof-mounted exhaust fan with HEPA filters. In conjunction with dampered inlet and exhaust vents, it is operated to maintain a slight negative pressure in the building and to automatically place the system in a "contained" state when air monitors detect radioactivity.

The exhaust air from the cells is passed through a minimum of two sets of HEPA filters and discharged to the 3039 stack system.

\section{A.2.4.2 History}

Building 3029 was constructed in 1952 and originally contained a system of remotely operated barricades and a small manipulator cell (now called Cell 4). The facility was built as part of, and has always been used in, the Isotopes Program. Isotopes originally handled in the facility were ${ }^{192}$ Ir (source fabrication) and small ${ }^{60} \mathrm{Co}$ sources. Cell 1 was built in 1955-56 to handle large quantities of $60 \mathrm{Co}$. Very little ${ }^{60} \mathrm{Co}$ source fabrication has been done since the late 1950s. Cell 3 was built in 1960-62 for ${ }^{137} \mathrm{Cs}$ source fabrication. Cell 2 was built by enclosing the space between Cells 1 and 3 and is used for waste handling and pass-through between the cells. Major building operations included $60 \mathrm{Co},{ }^{137} \mathrm{Cs}, 90 \mathrm{Sr}$, and $192 \mathrm{Ir}$ source fabrication.

\section{A.2.4.3 General Status}

The general status of Building 3029 is summarized in Table A.4. Current activities in the building are limited to removal of waste materials, transfer of $60 \mathrm{Co}$ inventory to retrievable storage, and cleanup of the facility.

- Cell 1 is used to transfer samples from a shipping cask to a smaller transfer cask for the M\&C Division. This work is performed about every 2 to 3 months.

- Iodine-131 is processed in Glove Box A in the southwest corner of the operating area. The iodine is used to test the High-Flux Isotopes Reactor (HFIR) filter system. This work is performed every 6 months.

- Cell 2 has waste that is being loaded out as manpower allows.

\section{A.2.5 BUILDINGS 3030/3031/3118-RADIOISOTOPES PRODUCTION LABORATORIES C, D, AND H}

\section{A.2.5.1 Description of Facilities}

Buildings 3030 and 3031, the Radioisotopes Production Laboratories, were designed for limited production and development processing of reactor-produced beta/gamma-emitting radioisotopes for industrial, medical, and research applications. Building 3118 was constructed by enclosing the space between Buildings 3030 and 3031 and covers the access doors to the cells in these buildings. 
Table A.4. Building 3029-general status of facility

Facility/area

Comments

\section{Building}

Type

Steel frame with metal siding.

Roof

Needs maintenance every 2 to 6 years.

Exterior walls

Cocooned with polyurethane foam.

Building containment and ventilation

Building sealed; air locks; operates to maintain a slight negative pressure in the building relative to the environment and to automatically maintain the system in a "contained" state when air monitors detect radioactivity.

Local area ventilation system; unshielded filter house with double HEPA filtration on the roof.

Cell ventilation: HEPA filters and exhaust to 3039 stack.

Liquid waste system

Building sinks and floor drains: process waste system.

Cell floor drains: drain to tank WC-10.

Cask handling

Forklift (9800-lb capacity).

Cells

Cells 1-3: used to process high-level beta/gamma sources $\left({ }^{137} \mathrm{Cs},{ }^{90 \mathrm{Sr}}\right.$, and in the past $\left.{ }^{60 \mathrm{Co}}\right)$.

Cell 4: short-lived radioisotopes, 192Ir.

Cell 1

Cell 1 is a transfer cell and is fairly clean.

No in-cell HEPA filters; filter house with double HEPA filtration on the roof. 
Table A.4 (continued)

Facility/area

Comments

Cells (continued)

Cell 2

Cell 2 is highly contaminated with beta/gamma radioactivity. Cell 2 contains waste.

HEPA filters in the cell and double HEPA filters on the roof.

Electrical system is deteriorating due to high radiation levels.

Cell 3

Cell 3 was decontaminated to 20 -mrem smears about 5 years ago. The contamination is mostly ${ }^{90} \mathrm{Sr}$, but there is some ${ }^{137} \mathrm{Cs}$.

Cell 3 is ducted to Cell 2 and filtered through the Cell 2 filter house. Cell 2 filter house is running with the damper fully open. The new system was connected to the roof of Cell 3, but the cell was never entered to install in-cell filters. The Cell 3 filter house is locked out.

No lights or electrical outlets due to radiation damage.

Cell 4

Cell 4 is fairly clean; it is used only for transfers.

No in-cell HEPA filters; double HEPA filters in outside filter house.

Operating Gallery

Iodine glove boxes

(enclosed hoods)

These glove boxes are hoods that were converted to glove boxes for processing elemental ${ }^{131} \mathrm{I}_{2}$ and $\mathrm{CH}_{3}{ }^{131} \mathrm{~L}$.

Drain to Glove Box B leaks. Leakage is alpha contaminated. The area under the box is alpha contaminated and is sealed. 
Table A.4 (continued)

Facility/area

Comments

Operating Gallery (continued)

Iodine glove boxes

(enclosed hoods)

(continued)

No alpha-monitoring instruments in the building.

East Wing

Cell access area

Area around the back doors of Cells 2 and 3 has high radiation readings. Lead shielding has been placed around the base of each cell. The background from this area causes the area to be zoned as a radiation zone. Radiation levels behind the lead bricks are 300 to $400 \mathrm{R} / \mathrm{h} .{ }^{137} \mathrm{Cs}$ contamination has migrated. Cleanup will require the removal of floor concrete and perhaps some removal of door concrete and/or removal of cell door operating trolley.

Contamination is leaking from under the Cell 3 door. Weekly cleanup is required. Smear counts usually 1000 to $1500 \mathrm{dpm}$.

60 Co garden

${ }^{14 C}$ glove box

There is a $60 \mathrm{Co}$ storage and irradiation facility (known as the $60 \mathrm{Co}$ garden) located under the floor of the east wing. The garden presently contains no sources and is fairly clean.

Contamination levels are not known but are considered to be high. Box is empty and has not been used for at least 5 or 6 years.

90Tc glove box

Used to weigh ${ }^{99} \mathrm{Tc}$ powder for shipment; slightly contaminated; all inventory has been removed.

${ }^{99} \mathrm{Tc}$ storage cabinets

All ${ }^{99} \mathrm{Tc}$ inventory has been removed. These are old lockable cabinets which were used for $99 \mathrm{Tc}$ storage remaining in the file.

West Wing

Storage well below the floor. 
These buildings are located in the west-central area of the Isotopes Circle and north of Building 3038.

\section{A.2.5.1.1 Building 3030}

Chemical processing of a wide variety of radioisotopes has been carried out in the single hot cell of Building 3030. Primarily, these were irradiated targets from the HFIR, the Oak Ridge Reactor facilities, and the 86-in. cyclotron.

Building 3030 is a steel-frame structure covered by corrugated aluminum siding. The single-story facility has a floor area of $825 \mathrm{ft}^{2}$. A manipulator-type hot cell is located on the middle of the east wall, as shown in Fig. A.5. Two laboratory hoods occupy the northeast section of the building. Since the building itself is not sealed, the manipulator cell and laboratory hoods constitute the primary means of containment. All high-level work was conducted in the hot cell. The hot cell has 2-ft concrete walls with 4 in. of lead brick shielding on the west (front) and south (side) cell walls and an unshielded top cover. The cell is provided with an oil-filled, leadglass window. A stainless steel operating pan covers the floor and interior walls up to the level of the viewing window. A 27- by 15-in. gasketed steel door port is used for insertion and removal of equipment. An administratively controlled, padlocked steel door at the back of the cell allows access from Building 3118 . This door is used mainly for transfer of shielded materials and large equipment. Personnel entry to the hot cell is allowed after decontamination has reduced radiation to a safe level.

The building operates at a slight negative pressure (nominally -0.15 in. w.g.) relative to the outside atmosphere. Since the siding is not sealed, the building cannot operate in a "contained" ( $<-0.3$ in. w.g.) state.

\section{A.2.5.1.2 Building 3031}

Building 3031 was being prepared for a proposed 90Y facility when the shutdown decision was made. Prior to that, the building had been used for processing $153 \mathrm{Gd}$, a medical radioisotope. The building is a single-story steel frame structure covered by corrugated metal siding with a floor area of $825 \mathrm{ft}^{2}$. It has one manipulator cell located in the middle of the west wall and hoods in the corners (Fig. A.6). The hot cell has 1-ft barytes concrete walls with 5 -in. steel armor plate on the operating (east) face of the cell wall starting $2 \mathrm{ft} 10 \mathrm{in}$. above the floor and an unshielded top cover. The cell is provided with a mineral oil-filled, lead-glass window. A stainless steel operating pan covers the floor and interior walls up to the level of the viewing window. Small steel doors on each side of the cell are used for insertion and removal of small equipment and containers. A thick steel double door at the back of the cell can provide access for large items from Building 3118 if needed. This door is padlocked against unauthorized use.

The building operates at a slight negative pressure (nominally -0.15 in. w.g.) relative to the atmosphere. The process of sealing the building for a proposed yttrium facility was started but not completed. As with Building 3030, Building 3031 cannot operate in a "contained" state. 
Building 3030

ORNL DWG 90-597

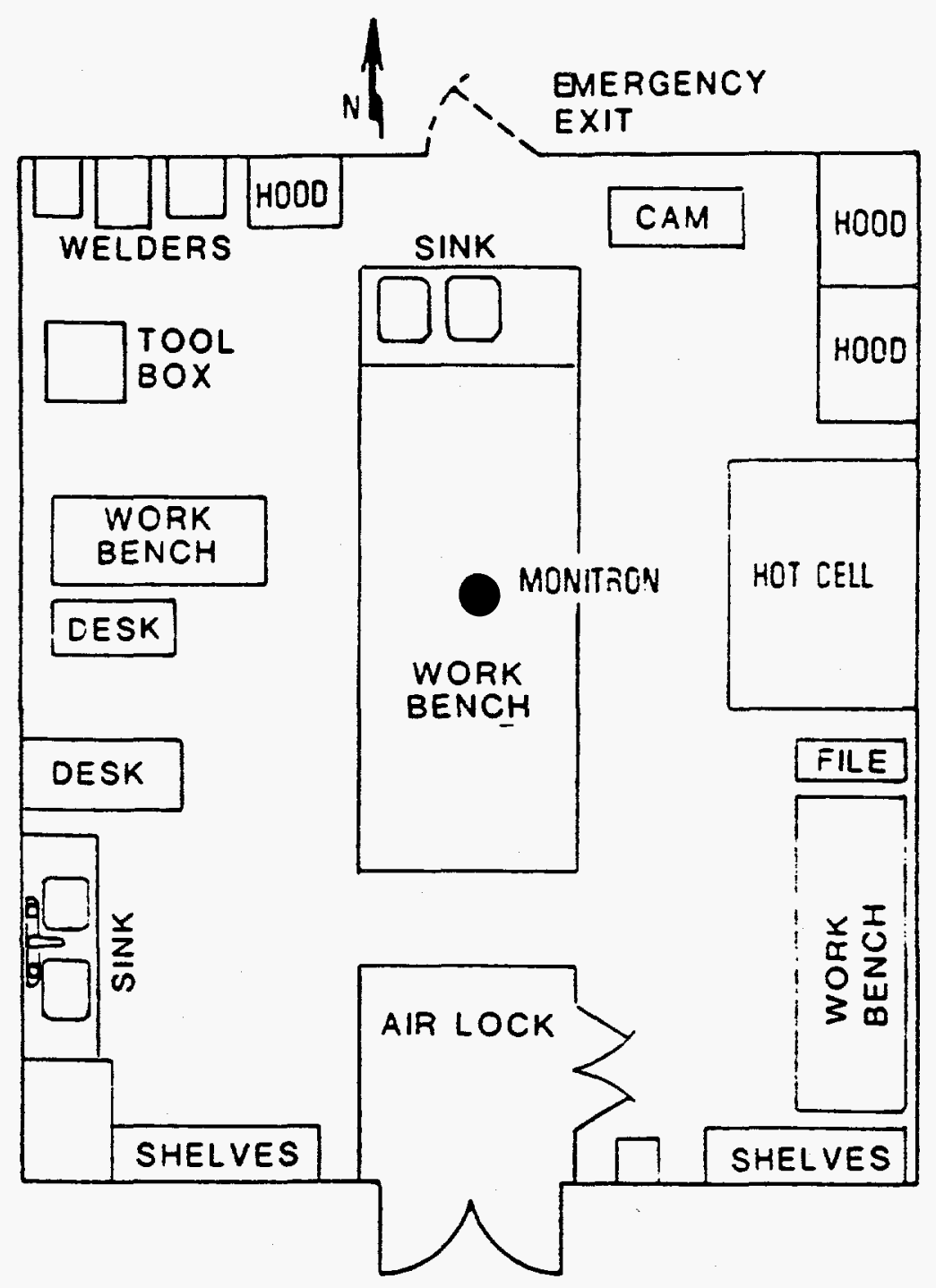

Fig. A.5. Floor plan of Building 3030—Radioisotope Development Facility. 


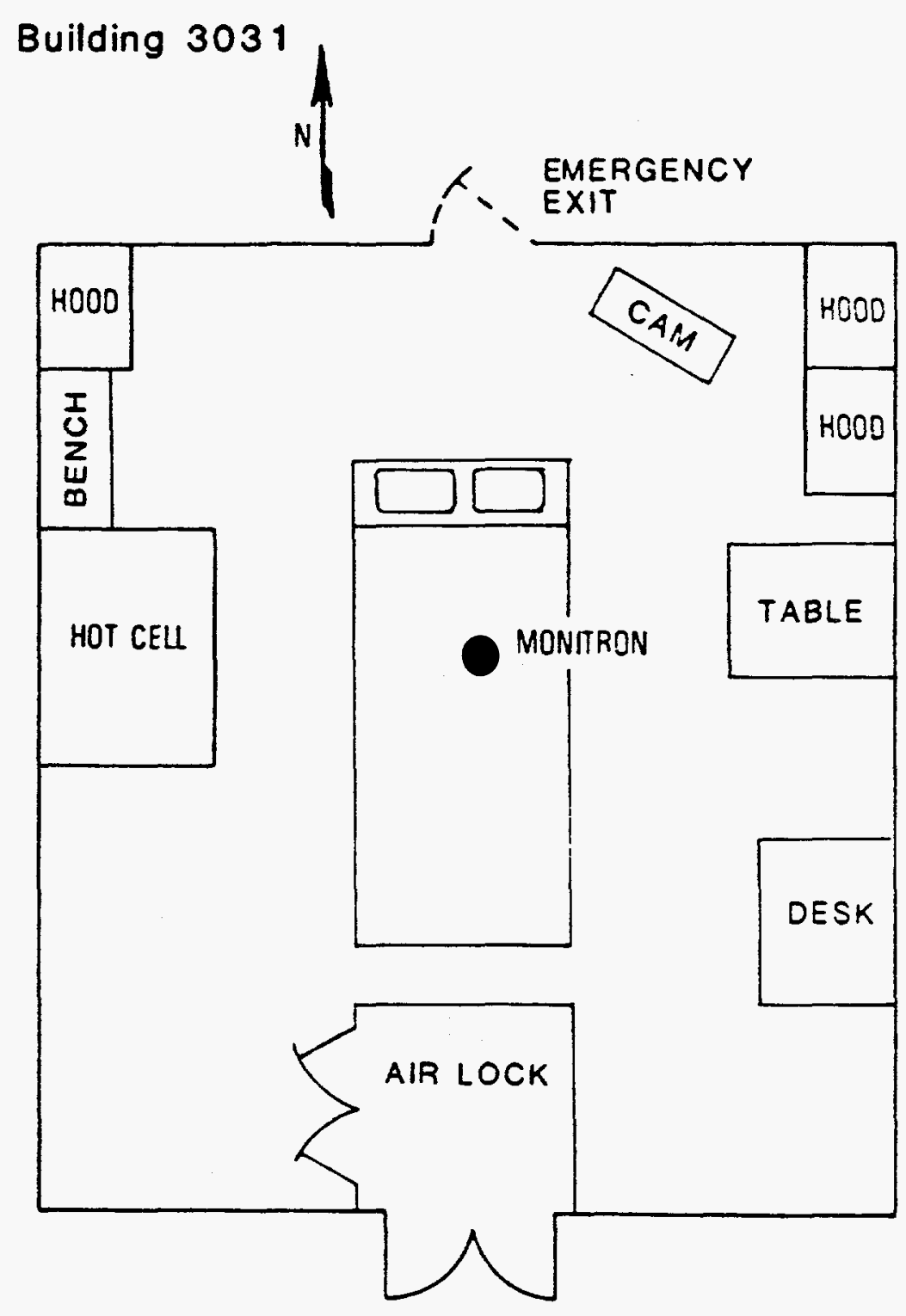

Fig. A.6. Floor plan of Building 3031-Radioisotope Development Facility. 


\section{A.2.5.1.3 Building 3118}

Building 3118 is a steel-frame structure covered with corrugated aluminum siding that was erected by roofing and enclosing the space between Buildings 3030 and $\mathbf{3 0 3 1}$. Building 3118 provides access to the rear entry doors for the hot cells in Buildings 3030 and 3031 , cask storage of some old radioactive sources, and temporary holding of contaminated waste.

\section{A.2.5.2 History}

Buildings 3030 and 3031 were constructed to perform limited production and development work with radioisotopes used for industrial, medical, and research applications. The hot cell in Building 3030 has been used to process irradiated cyclotron and reactor targets to produce numerous unique radioisotopes such as (1) 56 Co recovery from an iron target, (2) $57 \mathrm{Co}$ recovery from a nickel cyclotron target, (3) preparation of a purified $198 \mathrm{Au}$ solution, (4) purification of $55 \mathrm{Fe}$, (5) separation of $234 \mathrm{~Np}$ from a uranium target, (6) processing of $75 \mathrm{Se}$, (7) preparation of purified $90 \mathrm{Sr}$ nitrate, (8) processing of $119 \mathrm{mSn},(9)$ purification of $237 \mathrm{U},(10)$ processing of $33 \mathrm{P}$, and (11) processing of $192 \mathrm{Ir}$.

The hot cell in Building 3031 was used in the final separation stage of gadolinium from europium targets. The ${ }^{153} \mathrm{Gd}$ processed here is used in nuclear medicine research to determine bone density for osteoporosis research and treatment evaluation.

Building 3118 is basically a shed covering the rear-entry doors to the hot cells in Buildings 3030 and 3031 . It was added in the early 1960 s.

\section{A.2.5.3 General Status}

The general condition of Buildings 3030,3031 , and 3118 is summarized in Tables A.5, A.6, and A.7 respectively. There are no current operations in Building 3030 or 3031 . Building 3118 is used for forklift storage and temporary holding of contaminated waste as well as other storage. Building 3118 may be used for forklift storage and as a waste staging area during deactivation tasks.

\section{A.2.6 BUILDING 3033-TRITIUM AND KRYPTON PRODUCTION FACILITY}

\section{A.2.6.1 Description}

The tritium and krypton production facility is housed in Building 3033 , which is located in the central area of the Isotopes Circle, northeast of Building 3038. This building contains two separate radioisotopes processing systems for handling gaseous ${ }^{3} \mathrm{H}$ and ${ }^{85} \mathrm{Kr}$.

The building is a steel-frame structure covered with aluminum siding. The floor space is about $1200 \mathrm{ft}^{2}$ with a total volume of about $20,000 \mathrm{ft}^{3}$. The outer surface of the building has been sealed by a cocooning process to make it as airtight as possible. 
Table A.5. Building 3030-general status of facility

\section{Building}

Type

Roof

Exterior walls

Building ventilation

Liquid waste systems

\section{Cell and Hoods}

Cell

Hoods

Laboratory

West Wall
Steel frame with metal siding.

Needs maintenance every 2 to 6 years.

Siding is not sealed; leak in the wall when it rains.

Operates at a slight negative pressure (nominally -0.15 in. w.g.); building is not sealed; air lock on front entry.

Building ventilation provided by local system; exhaust to unshielded filter house (double HEPA filtration) on roof.

Building sink and floor drains: process waste system. Cell floor drain: drains to tank WC-10.

Beta/gamma hot cell.

In-cell roughing filter. Cell ventilation and process offgas routed to concrete block, shielded, filter house in the alley north of Building 3030 . Concrete block walls must be unstacked to service filters.

Manipulator boots need replacing.

Contaminated.

Small quantities of ${ }^{63 \mathrm{Ni}}$ and $103 \mathrm{Pd}$ are present in the facility.

Abandoned hot drains and hot off-gas lines under floor. 
Table A.6. Building 3031-general status of facility

Facility/area

Comments

Building

Type

Roof

Exterior walls

Building ventilation and containment

Liquid waste systems

Cell and Hoods

Cell
Steel frame with metal siding.

Needs maintenance; leaks.

Cocooning process incomplete; exterior has been sprayed with a cocooning material.

Operates at a slight negative pressure (nominally -0.15 in. w.g.).

Process of sealing building for a proposed yttrium facility was started but not completed. Ventilation system partially modified. Air lock installed at single entry door.

Building sink and floor drains: process waste system.

Beta/gamma hot cell.

Contamination levels are unknown, but recent history suggests low. Relatively "clean." One can of waste in cell.

Cell ventilation exhaust has double HEPA filtration; no in-cell filter.

Process off-gas with double HEPA filtration.

No in-cell electrical service; electrical through access ports only. 
Table A.6 (continued)

Cell and Hoods

One enclosed hood

Contamination level, $6000 \mathrm{dpm}$ on exposed surfaces.

Equipped with glove ports; lead shielding; drain to tank WC-10.

Two hoods

Contamination level below $2000 / \mathrm{dpm}$ on exposed surfaces.

Higher levels suspected at exhaust areas.

Each equipped with process waste drain. 
Table A.7. Building 3118 - general status of facility

Facility/area

Comments

Building

Type

Metal shed on concrete pad.

Roof and walls

Acceptable for use.

Building ventilation

Building is not sealed; no air locks.

No air conditioning.

Liquid waste system

Sink: process waste treatment.

Floor drain that is plugged; drains to tank WC-10; must pull plug to use.

Stored materials

Forklift.

Storage of waste materials prior to analyses. Storage of cask and other equipment (i.e., manipulators) used in adjacent facilities. 
Personnel and equipment entrances are gasketed. The building is maintained at a pressure of -0.3 in. w.g. or more relative to the outside atmosphere. The three areas of the building-the krypton process cell, the tritium process room, and the utility area-are shown in Fig. A.7.

The krypton process cell consists of a composite shielded enclosure made of 2.25-in.-thick steel plate overlaid with 1 in. of lead, supported by a 8-in.-thick by 2-ft-high concrete wall at the bottom. Part of the enclosure houses the in-process storage tanks and is made of stacked 4-in.-thick lead bricks. The main enclosure pressure is maintained at -1 in. W.g. relative to the room pressure.

The separation columns and carbon reactor are housed in a separate enclosure, which consists of a steel frame overlaid with 4 in. of lead brick. The permanent storage cubicle, which contains four charcoal-filled storage tanks, is located outside the building. It consists of a nonventilated 2 -ft-thick reinforced-concrete enclosure. The krypton feed gas is located inside a 1-in.-thick steel plate enclosure, which is also outside the building. Process components contained in the enclosure are connected with 3/8-in. copper tubing shielded by 1-in. lead. Each of these enclosures (with the exception of the permanent storage which is not in service) is connected to the isotopes area cell ventilation system.

Tritium radiation consists of a relatively soft beta emission, which produces essentially no penetrating radiation hazard. The tritium is handled in a hood inside the tritium room. The hood is connected to the isotopes area cell ventilation system and is maintained at a nominal -0.5 -in. w.g. relative to the tritium room.

\section{A.2.6.2 History}

Building 3033 was used to process ${ }^{14} \mathrm{C}, 85 \mathrm{Kr}$, and ${ }^{3} \mathrm{H}$. Processing of $14 \mathrm{C}$ was discontinued in 1975 . No future ${ }^{85} \mathrm{Kr}$ processing in Building 3033 is planned. The last operations in Building 3033 consisted of two separate radioactive gas processing systems. Tritium operations involved the receiving of bulk tritium shipments from the Savannah River Plant, followed by purification, loading of shipping containers, and shipment to numerous customers worldwide. Krypton operations included the purification of $85 \mathrm{Kr}$ (as received from the Idaho National Engineering Laboratory) in preparation for direct sale or as feed to the thermal diffusion columns in Building 3026-C. The processing of $3 \mathrm{H}$ for sale to private industry was discontinued in 1990. The last $85 \mathrm{Kr}$ campaign was conducted in September 1989.

The general status of the facility is summarized in Table A.8.

\section{A.2.7 BUILDING 3033-A-ACTINIDE FABRICATION FACILITY}

\section{A.2.7.1 Description}

Building 3033-A (Annex) was used to house and contain the facilities for the production, loading, welding, and decontamination of neutron dosimeter materials as well as the weighing and packaging of milligram to gram quantities of actinide 


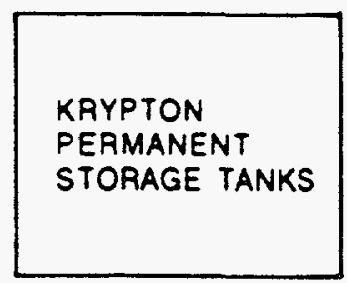

BUILDING 3033

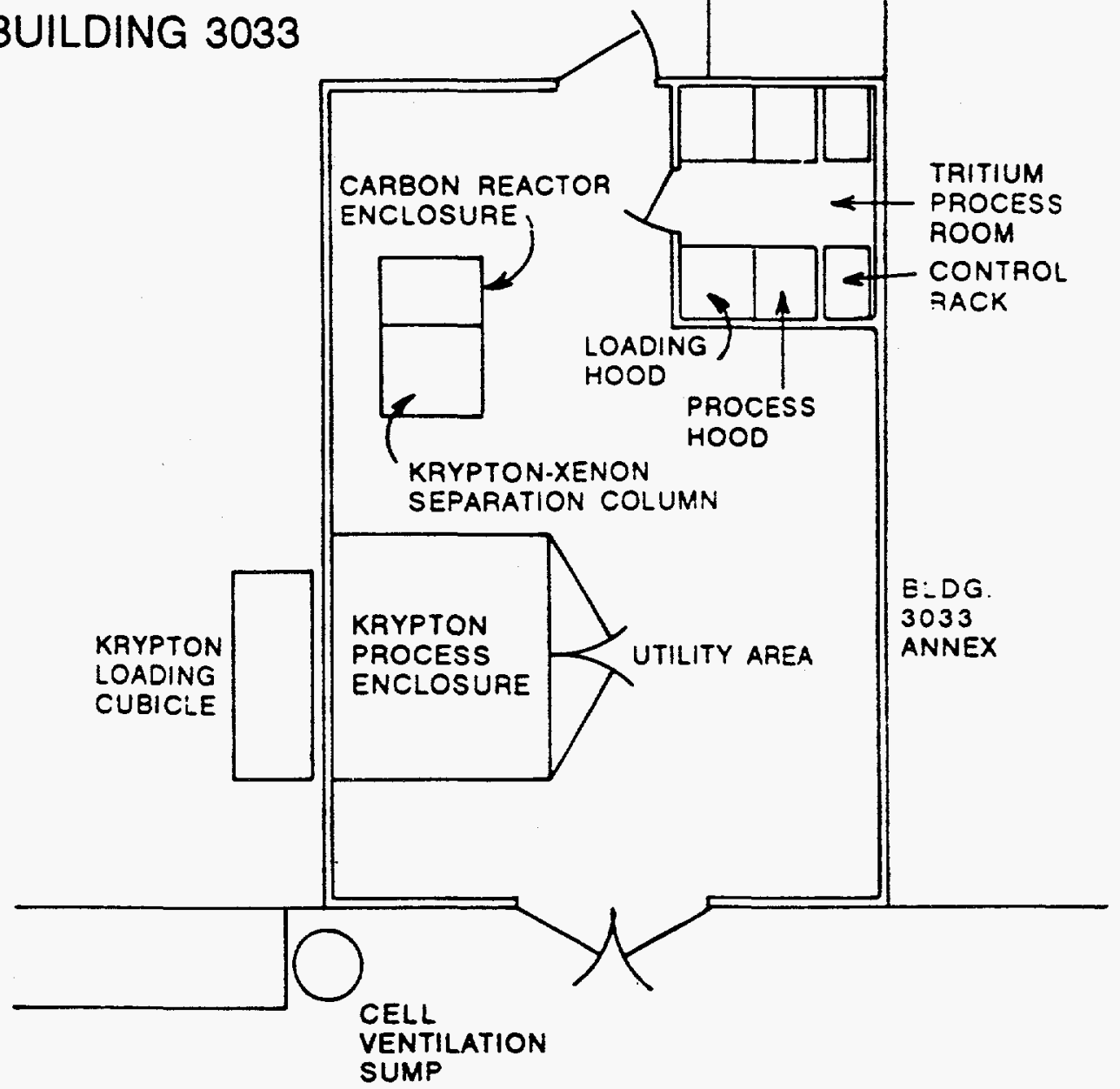

Fig. A.7. Floor plan of Building 3033-Tritium and Krypton Production Facility. 
Table A.8. Building 3033-general status of facility

Facility/area

Comments

Building

Type

Roof

Exterior walls

Building containment and ventilation

Liquid waste systems

\section{Cells and Hoods}

North hood system in tritium room

South hood system in tritium room
General condition good, considering age of facility.

Metal shed on concrete pad.

Replaced in 1988.

Cocooned with polyurethane foam; need maintenance every 2 to 6 years.

Building sealed; building operates in a "contained" state to maintain a $>0.3 \mathrm{in}$. w.g. negative pressure relative to the outside environment. (In practice, building operates at about 0.45 in. negative pressure.)

Both building ventilation and cell ventilation are on the isotopes area cell ventilation system and exhaust to the 3039 stack. No HEPA filters are present because only radioactive gases are handled in the building.

Processes do not generate liquid wastes.

Cell drains to tank WC-10; drain kept open but has not been used in 17 years (or longer).

Uncontaminated; tritium has never been introduced to system; the two uranium traps have never, been activated (i.e., never used for tritium storage).

All bulk tritium has been removed from the uranium traps. Tritium processing equipment remains highly contaminated with tritium. Tritium exchanges with water-oxide coating (HTO) on surface of the metal. Elemental tritium is also contained within the metal matrix of all metal parts of the system. 
Table A.8 (continued)

Facility/area

Comments

Cells and Hoods (continued)

South hood system in tritium room (continued)

Three uranium traps used for storing and purifying tritium. One trap was poisoned by an inleakage of air and taken out of service. All three traps are pyrophoric.

Krypton cell/system Minimal contamination of deactivation equipment due to inert nature of krypton. Relatively new system. 
materials for research applications. The building does not contain a hot cell and was used only for low-level radioactive operations in glove boxes and one hood. Special nuclear materials were, at one time, stored in the building.

Building 3033-A is located in the central portion of the Isotopes Circle, south of Building 3047. It is a metal structure erected by bridging the space between Buildings 3033 and 3034 and using their walls for support. Floor space is about $242 \mathrm{ft}^{2}$, with a free-space volume of about $718 \mathrm{ft}^{3}$. Personnel access is through gasketed, airlock entries. The building layout is presented in Fig. A.8.

The building is maintained at a pressure of -0.25 in. w.g. relative to the outside atmosphere. The exhaust discharges to the 3039 stack via the isotopes area cell ventilation system. The air leaving Building 3033-A passes through roughing and HEPA filters, which are routinely tested.

\section{A.2.7.2 History}

Building 3033-A, which was constructed in approximately 1960, included two operating areas: a small one for ${ }^{14} \mathrm{C}$ production at the south end of the building operated by the Radioisotopes Department and the larger, main operating area for research materials preparations performed by Isotopes Research Materials Laboratory (IRML) personnel. In the early 1980s, IRML personnel decontaminated and decommissioned the ${ }^{14} \mathrm{C}$ facility, including removal of the underground dissolver tank, and converted this area for storage.

This building has been used almost exclusively for the preparation and distribution of highly enriched actinide isotopes (and for a period, 14C) for the Isotopes Program. Among the operations performed were

- fabrication of ceramic oxide wires;

- loading of ceramic oxide wires, oxide powder, or metal into small metal capsules for use as in-core reactor neutron dosimeters;

- fabrication of monoenergetic gamma sources;

- weighing and packaging of milligram to gram quantities of actinide materials;

- preparation of nanogram to milligram actinide samples for alpha counting;

- decontamination of nuclear material shipping containers; and

- storage of radioactive materials.

Over the years, many other small special projects have been performed in this facility, including, for example, the packaging of actinide materials for disposal or shipment as a service to the Safeguards and Security Department.

\section{A.2.7.3 General Status}

All production operations in Building 3033-A were halted in January 1990 because of funding problems. All special nuclear materials once stored in this facility have been transferred to other ORNL or DOE sites or disposed of as waste. All glove boxes 
$A-41$

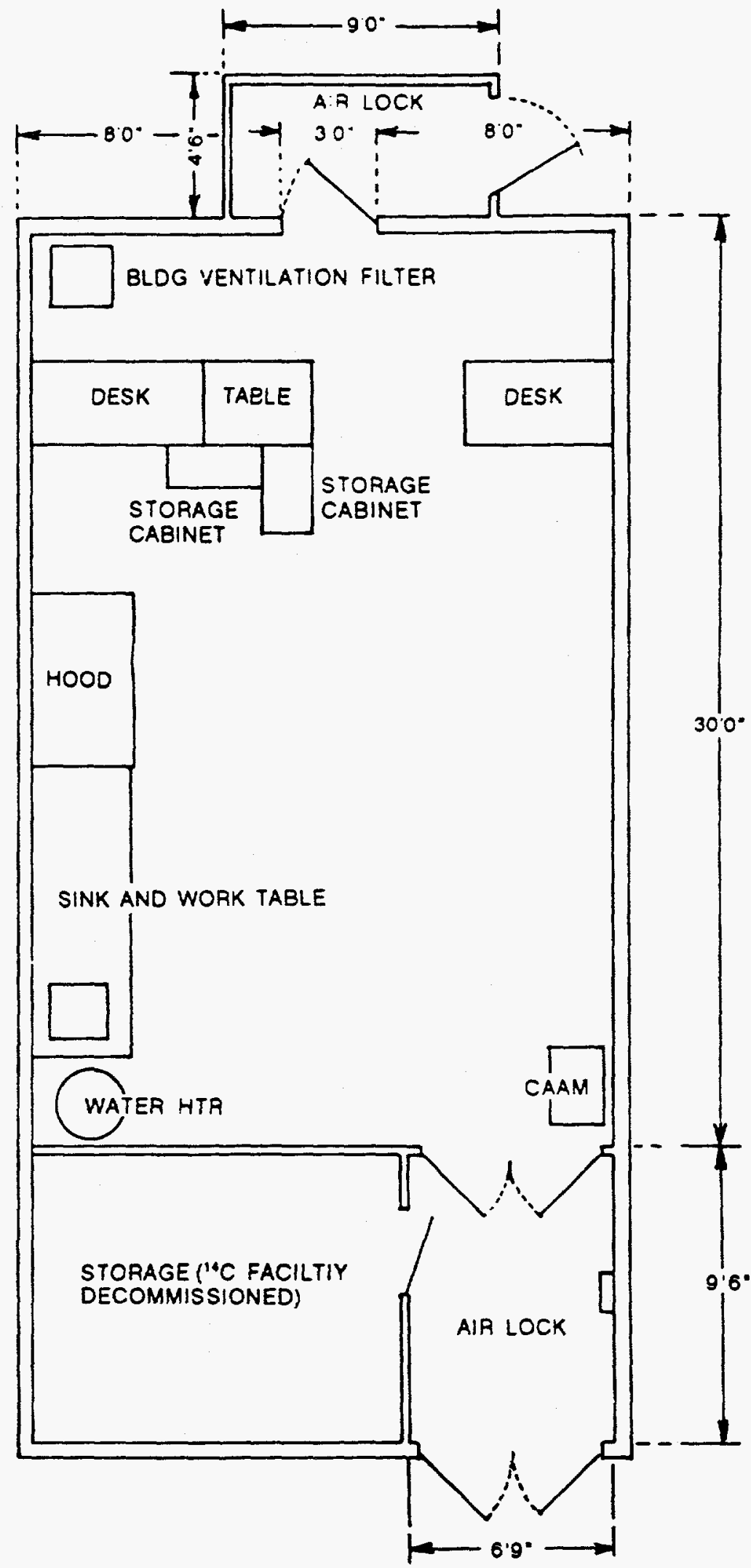

Fig. A.8. Floor plan of Building 3033-A-Actinide Fabrication Facility. 
have been removed, and a general (first cut) decontamination of the building has been completed.

The general status of this facility is summarized in Table A.9.

\section{A.2.8 BUILDING 3038-ISOTOPES RESEARCH MATERIALS LABORATORY, ISOTOPES SHIPPING, ISOTOPES TECHNOLOGY, AND ALPHA HANDLING FACILITY}

\section{A.2.8.1 Description}

Recent uses of Building 3038 include the study of transuranic elements, fabrication of alpha- and neutron-emitting targets and sources, shipment of radioisotopes, and production of $90 \mathrm{Y}$ for medical uses. The building, which is located on the southwest corner of Isotopes Circle, is a masonry and steel-frame structure with a total of floor area of $7250 \mathrm{ft}^{2}$ and a total free space volume of $130,000 \mathrm{ft}^{3}$. It is divided by concrete block interior walls into three separate facilities: 3038-E, 3038-M, and 3038-AHF.

The building rooms and equipment are maintained in a "contained" condition using the isotopes area cell ventilation and process off-gas systems and a local ventilation system. Various heating and cooling systems are provided in the different operating areas. The cell ventilation system exhausts air from the east area and equipment (including the manipulator cell) to an unshielded filter house on the roof, which discharges to the 3039 stack. The isotopes area process off-gas system provides exhaust for the manipulator cells in the AHF and the glove boxes in the AHF Annex with local HEPA filters prior to discharge to the ORNL process off-gas system. The local ventilation system provides room exhaust for Radioactive Materials Shipping and Packaging (RAMSPAC), the AHF, the AHF Annex, and the Isotopes Technology Low-Level Laboratory. The exhaust goes to a filter house on the roof where an exhaust fan draws air through the HEPA filters and discharges up a short roof stack. The filters in the various cells, glove boxes, and hoods are given in the description of the individual laboratories.

The east end is provided with an air lock for personnel access. The personnel access to the RAMSPAC area in 3038-M also has an air lock. Other personnel access entries and equipment access doors are not provided with air-lock capability, which results in upsets to the desired "contained" condition. The combination of local and process off-gas systems presents a potential for reversed flows and contamination if one of these systems should fail.

The drains in the east and middle sections of the building, which were once connected to the LLLW system, have been sealed to prevent use because of leaks in the underground transfer lines. This includes, in addition to the hot cell in 3038-E, hood and sink operations. There is no provision for wash down to decontaminate the hot cell or for cleanup of contamination in the barricade area. The hot drains for the alpha handling cells in the west end of the building are on the WC-2 tank system. 
Table A.9. Building 3033-A-general status of facility

Facility/area

Comments

\section{Building}

Type

Roof

Exterior walls

Building containment and ventilation

Liquid waste systems

Security
Steel frame with metal siding; shares common loadbearing wall columns with adjacent buildings.

Leaks.

Cocooned; need maintenance to seal leaks.

Building cocooned; air locks; leakage problems; building is maintained at a nominal negative pressure of $0.25 \mathrm{in}$. w.g. relative to the outside atmosphere.

Building ventilation: roughing and HEPA filters (filter house inside building); exhaust to isotopes area cell ventilation system and 3039 stack.

A contaminated off-gas manifold that once serviced the glove boxes in this facility still exists. The remaining system consists of an in-house filter box with dual series of HEPA filters valved so that one set may be isolated and bypassed during change-out; exhaust to isotopes area cell ventilation system and 3039 stack.

Hood: HEPA filter, exhaust to isotopes area cell ventilation system and 3039 stack.

Drain in hood, west wall (normally sealed): drains to tank WC-10.

Laboratory sink, one hood drain, building floor drain: process waste treatment system.

Facility locked when personnel are not present. 


\section{A.2.8.1.1 East-end laboratories}

The east-end laboratories of Building 3038 contain glove boxes and hoods (Fig. A.9). The glove boxes contain equipment for the fabrication of radioactive targets and for the examination of materials by both destructive and nondestructive tests. The glove boxes and hoods have one stage of HEPA filtration in the box or hood, a second stage of HEPA filtration in the filter house on the roof, and then discharge to the cell ventilation system. Nonradioactive liquid wastes are discharged to the process waste system. There is no provision to valve off the process waste system in the east-end area. There is no LLLW system in the east-end facility. There is a storm drain for cooling water from diffusion pumps and electrical equipment that have no potential for radioactive contamination.

The principal radioactive materials in the east end are uranium, transuranic elements, and $147 \mathrm{Pm}$. Primary containment is provided by the glove boxes and hoods. The glove boxes are operated at a negative pressure $\geq 0.35$ in. w.g. relative to the laboratory.

\section{A.2.8.1.2 Radioactive Materials Shipping and Packaging}

The RAMSPAC area is located in the central portion of Building 3038 and consists of a now-empty concrete barricade for storage of isotopes products, a remote pipefitting station, a canning and packaging station, an area for health physics inspection, and an area for labeling of packages (Fig. A.10). The barricade consists of a concrete wall with lead brick shielding stacked $2 \mathrm{ft}$ high, two lazy-susan-type storage holders behind the shielded wall, a remote manipulator, and an overhead viewing mirror. The products were stored as liquids in glass bottles. The shipping area operates under the low-negative-pressure, high-air-flow principle. Air flow passes from the least hazardous areas over the barricade through a single stage of roughing filters followed by a single stage of HEPA filters on the roof and discharges to the atmosphere through a roof vent. There is no provision for wash down behind the barricade to clean up contamination known to exist because the hot drain has been sealed.

\section{A.2.8.1.3 Laboratories}

There are two laboratories: a process cell area in the east end of the building and a low-level laboratory in the west end located in Building 3038.

The process cell area has one manipulator cell (Cell 3), hoods, and a shielded counting room (Fig. A.11). The cell is constructed of 4-in. steel plate on all sides with a mineral oil-filled, leaded-glass viewing window and a 10 -in. ${ }^{2}$ access port. It is supported on concrete pillars. This cell was used for separating ${ }^{90} \mathrm{Y}$ from ${ }^{90} \mathrm{Sr}$ and is highly contaminated. There is no provision for wash down since the hot drain was sealed. An empty shielded counting room is adjacent. There is single-stage roughing filtration in the cell. Exhaust from the cell, hoods, and room is routed to a filter house on the roof (double-stage HEPA filtration) and discharged to the 3039 stack. 


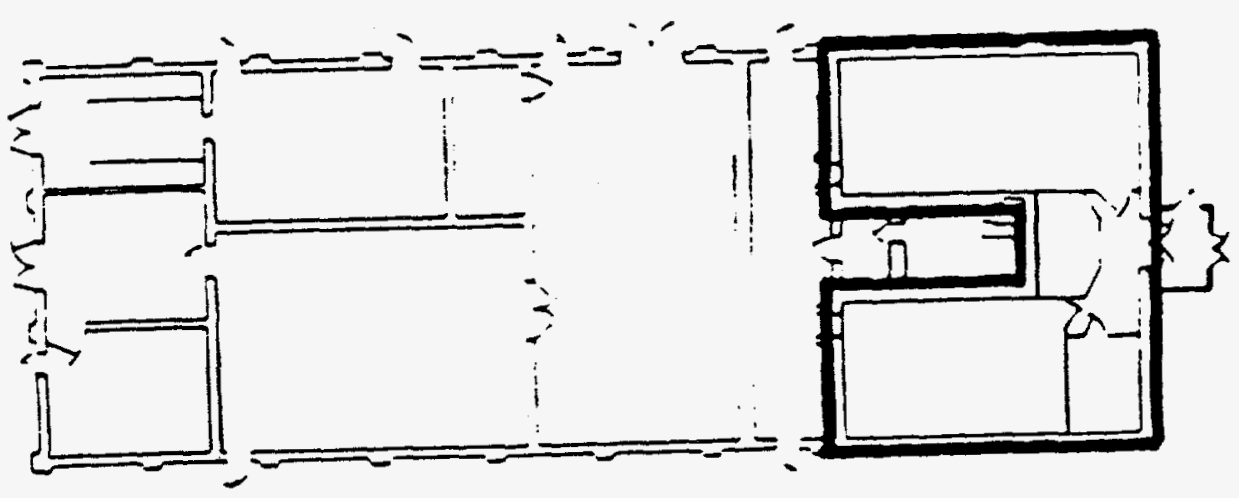

Building 3038

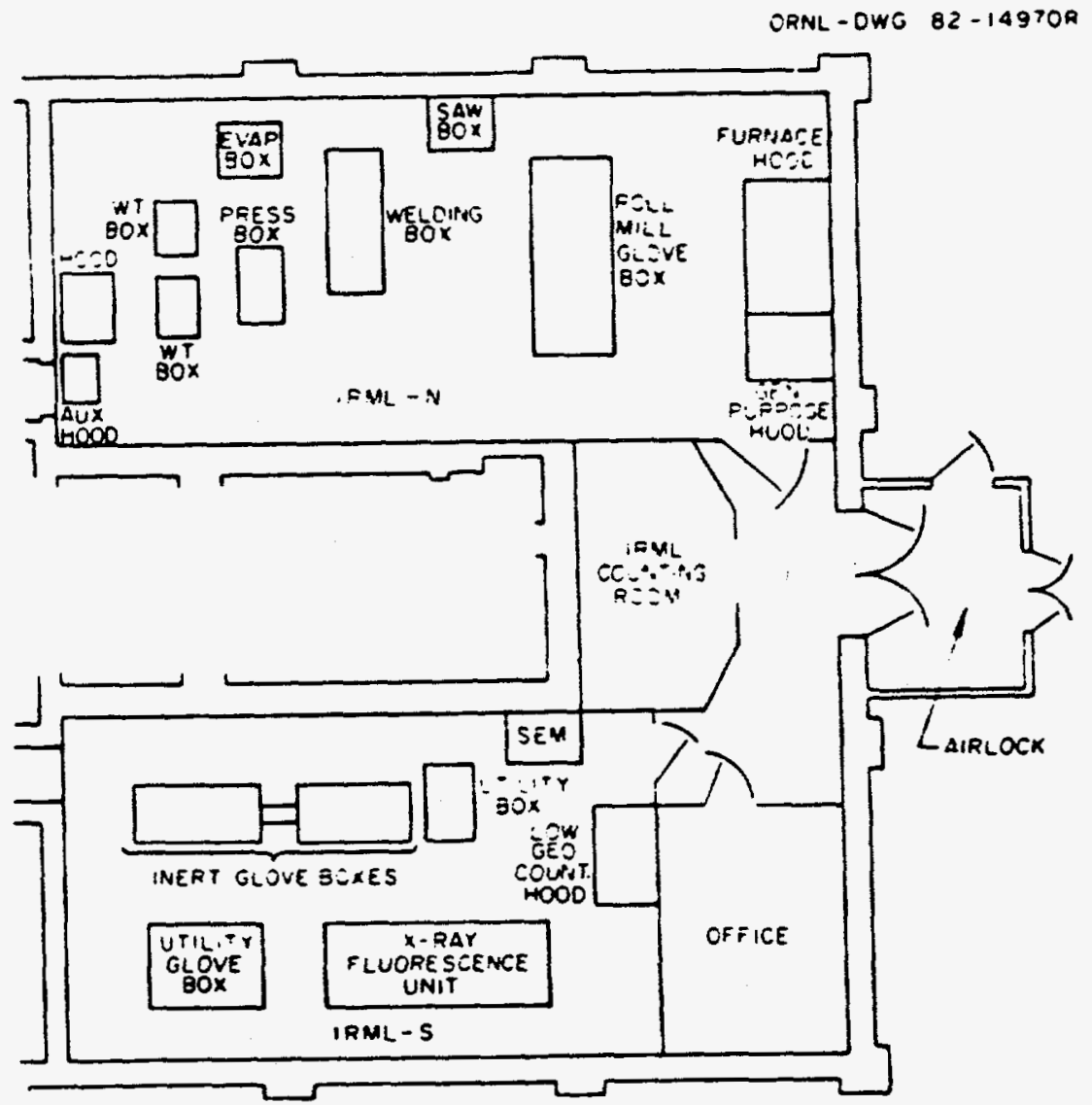

Building 3038-E

Fig. A.9. Floor plan of east-end laboratory in Building 3038. 


\section{$A-46$}

ORNL OWO D0-503

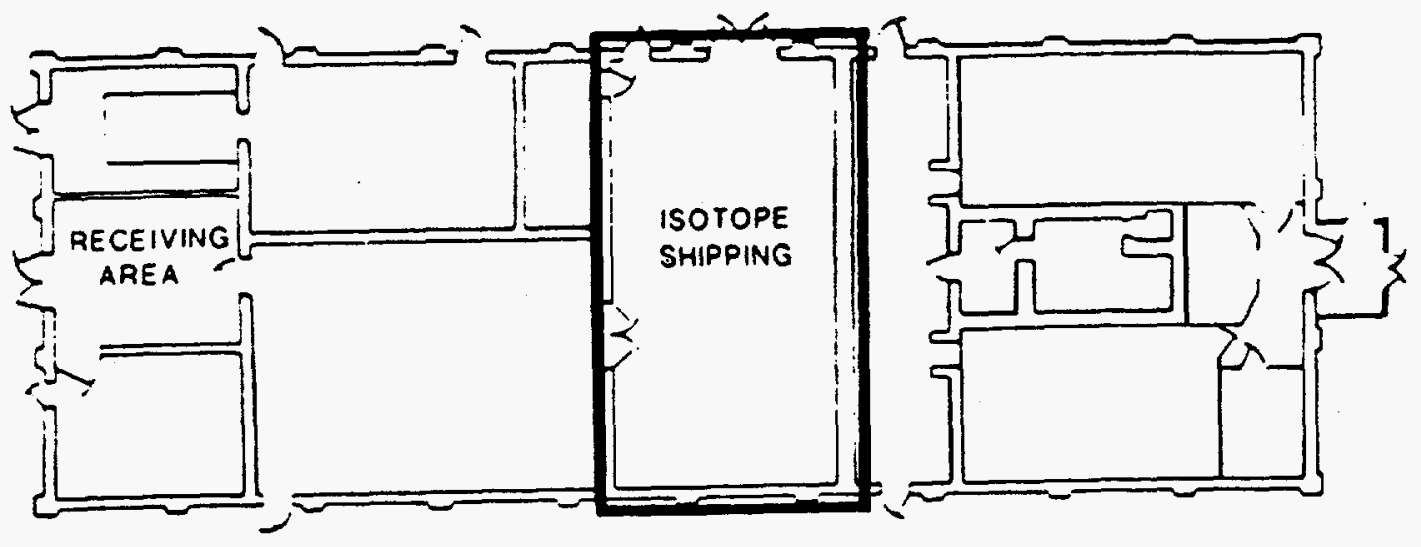

$\because \frac{i}{s} E$

Building 3038

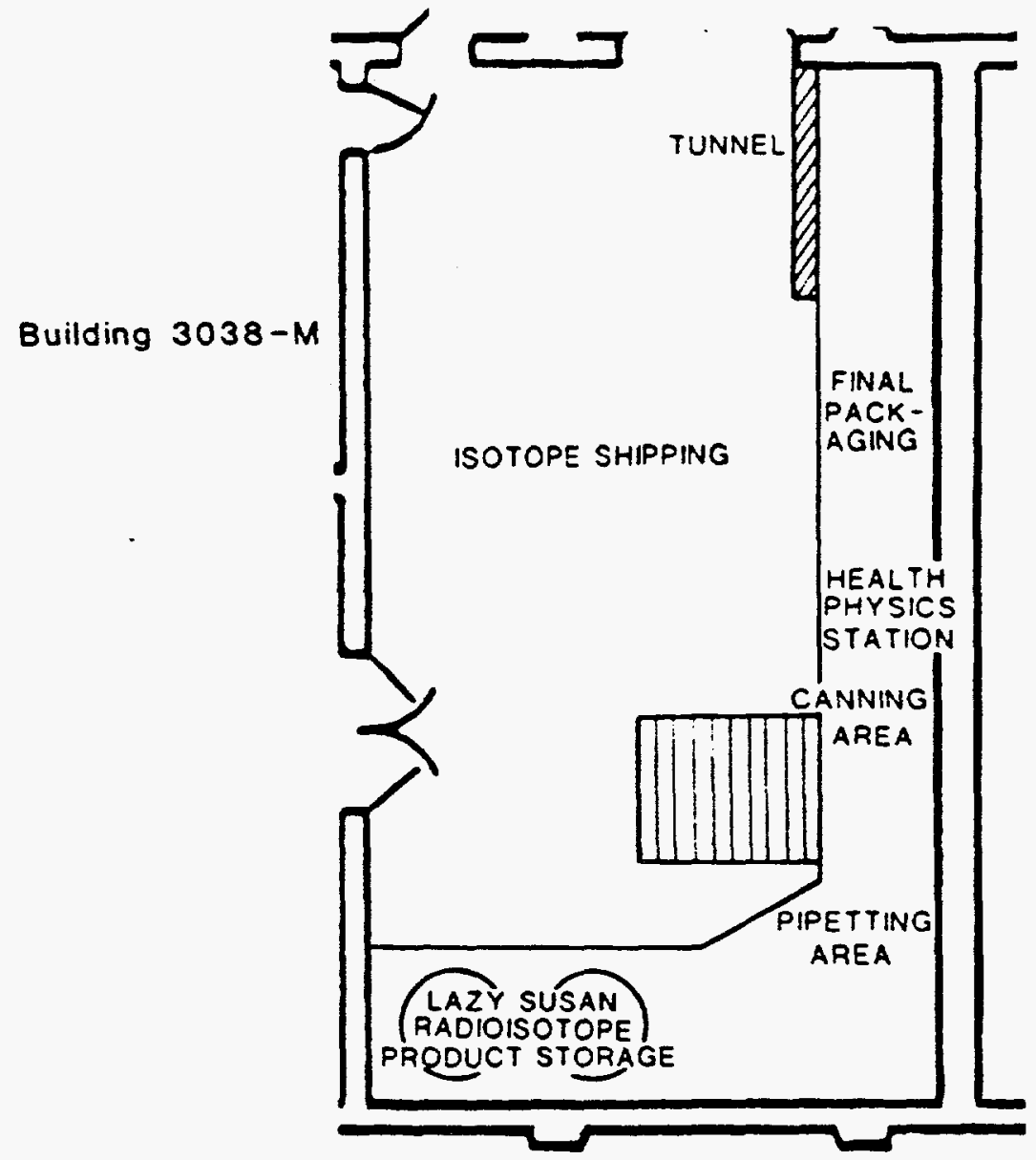

Fig. A.10. Floor plan of Radioactive Materials Shipping and Packaging in Building 3038. 


\section{Building 3038}
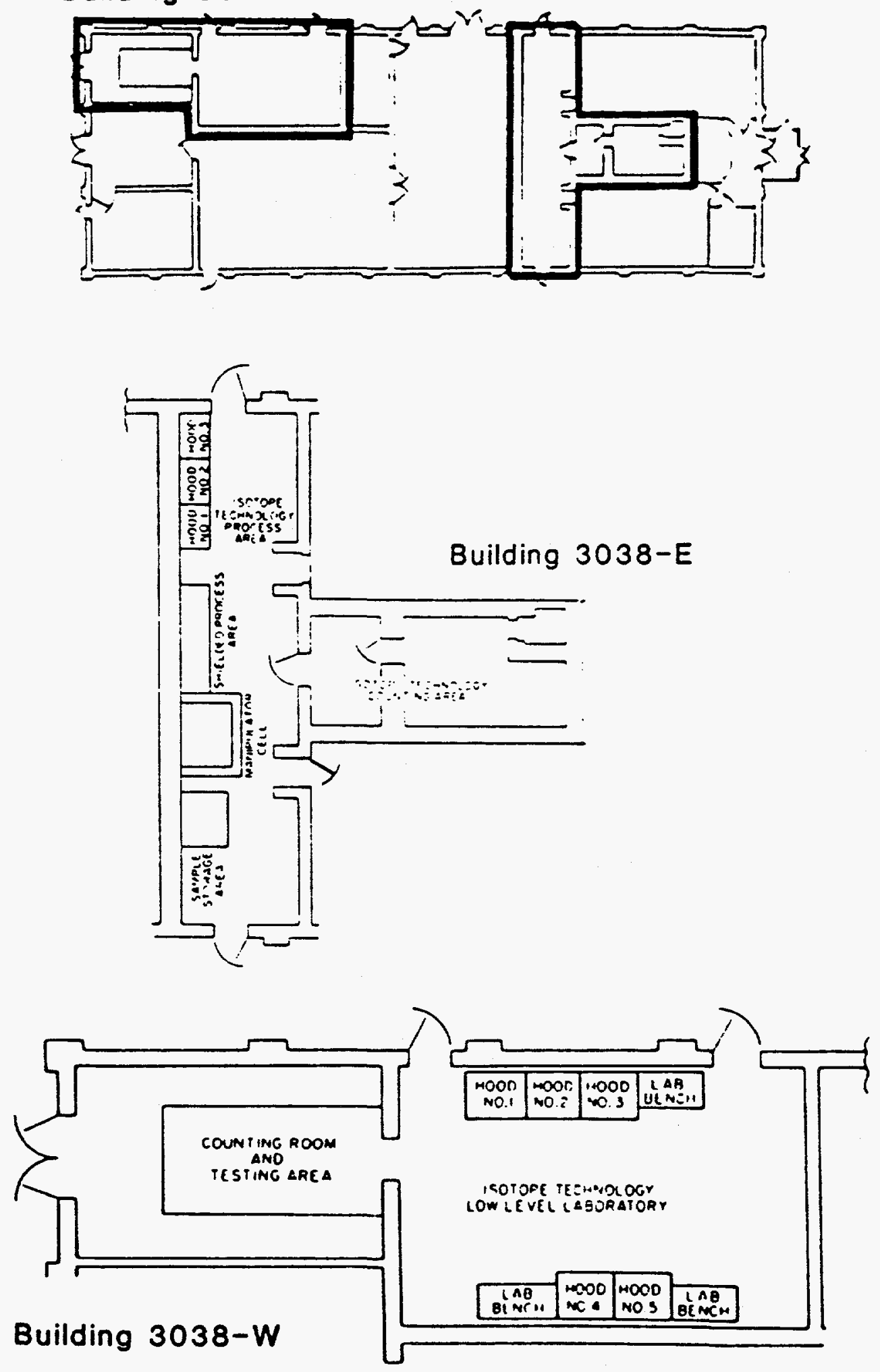

Fig. A.11. Floor plan of Isotope Technology Laboratories in Building 3038. 
The low-level laboratory includes a laboratory bench, five hoods, and an adjacent storage room (Fig. A.12). The hoods and sinks drain to the process waste system. There is no way to valve off this system. The only radioactive materials handled in this laboratory were tracer-level quantities of alpha and beta-gamma materials. Room air exhausts to the local system with single-stage HEPA filtration and is discharged through the roof stack. The storage room presently serves as a satellite waste accumulation area for Resource Conservation and Recovery Act of 1976 waste.

\section{A.2.8.1.4 Alpha Handling Facility}

The AHF in the west end of Building 3038 consists of five hot cells. A separate room, the AHF annex, occupies the southwest corner of the building and includes seven glove boxes for weighing, packaging, and welding capsules. The floor plan of these two rooms is shown in Fig. A.13.

The hot cells are shielded by water-filled steel tanks. The operating face of each cell has $3 \mathrm{ft}$ of shielding, is $6 \mathrm{ft}$ wide by $8 \mathrm{ft}$ high, and contains a viewing window and manipulator ports. Each cell is $10 \mathrm{ft}$ deep. The cell tops are unshielded except for the liner. One foot of water shielding is provided between cells. The building wall, consisting of $1 \mathrm{ft}$ of concrete, forms the back of the cells. These cells can be used as glove boxes by replacing the front shielding tank and manipulators with an approved window equipped with glove ports and a loadout station. The alpha cells drain to the WC-2 tank system.

The cells are ventilated by the process off-gas system. The maximum negative pressure available to the cells is limited to -4.0 in. $\mathrm{H}_{2} \mathrm{O}$ (gauge) by a vacuum breaker in the off-gas header. There are single-stage HEPA filters in the cells and glove boxes and a second stage of HEPA filtration before discharge to the process off-gas system. Additional treatment is provided at the 3039 stack. The room air exhaust from the AHF and the AHF annex has single-stage HEPA filtration in the duct and a second stage in the filter house on the roof before discharge through a short roof stack.

\section{A.2.8.1.5 Receiving area}

This area serves as the receiving depot for all radioactive materials which are delivered to the central ORNL site (Fig. A.14). This activity will be moved to Building 3036.

\section{A.2.8.2 History}

Building 3038 was constructed to house all the radioisotopes shipping activities for ORNL. The building has been in operation since 1949. Originally, the entire facility was dedicated to radioisotopes shipping as follows: the east portion (3038-E) contained the analytical chemistry laboratory to perform analyses of short-lived radioisotopes prior to shipment; the middle section (3038-M) housed the radioisotopes handling and transfer barricade; and the west section housed the packaging, inspection, and shipping activities. 


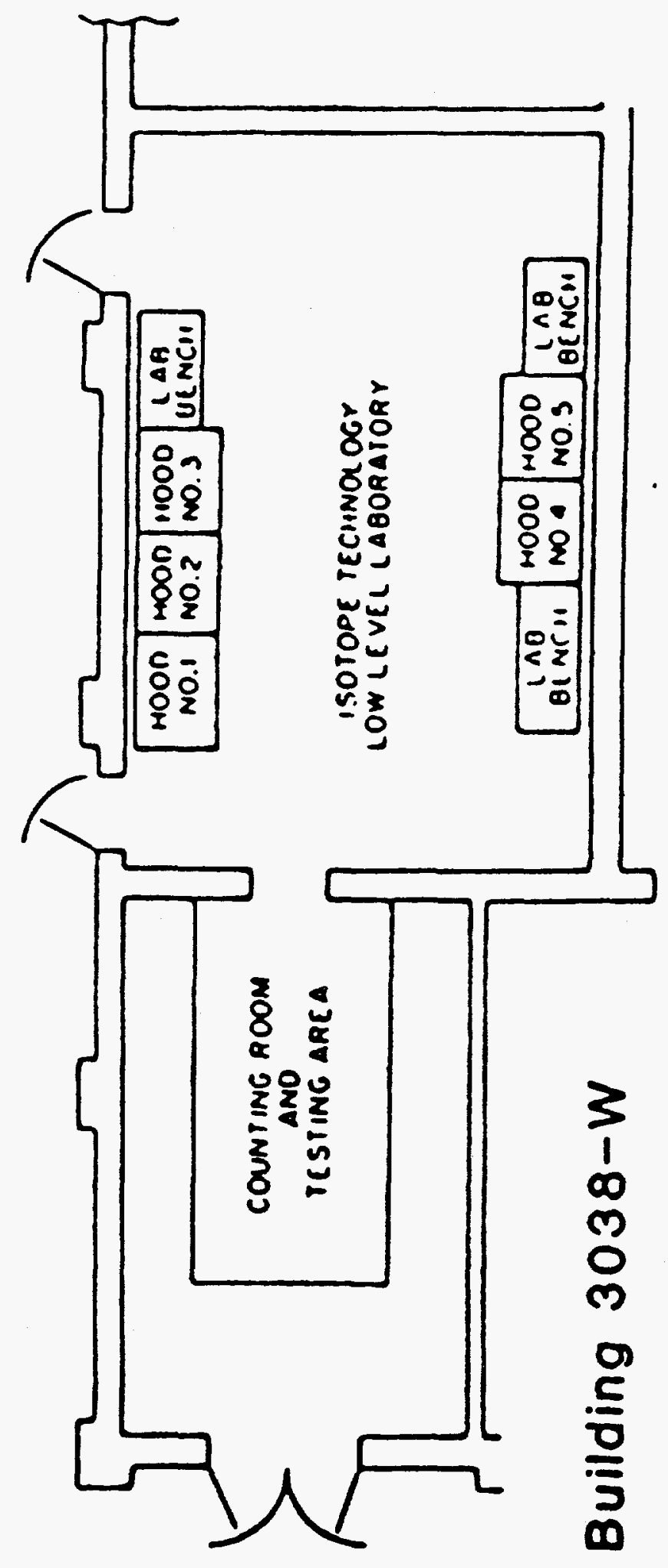


ORNL DWG 90-501

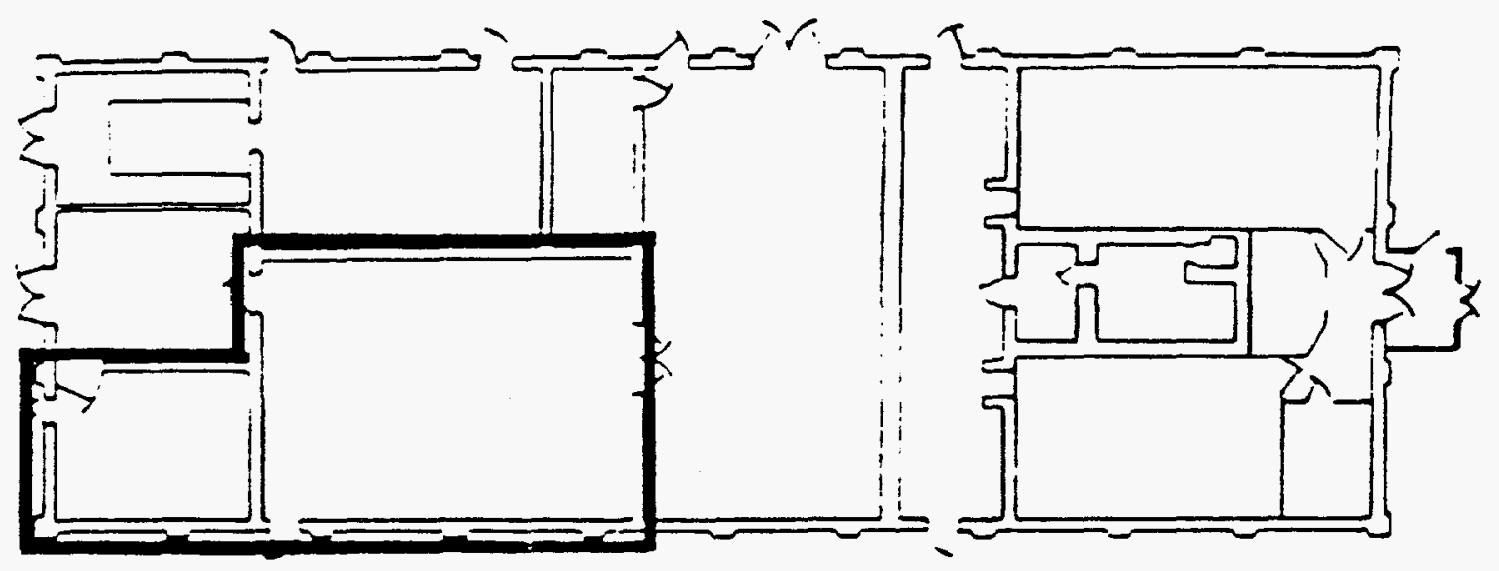

Building 3038

$n+\frac{i}{s}$

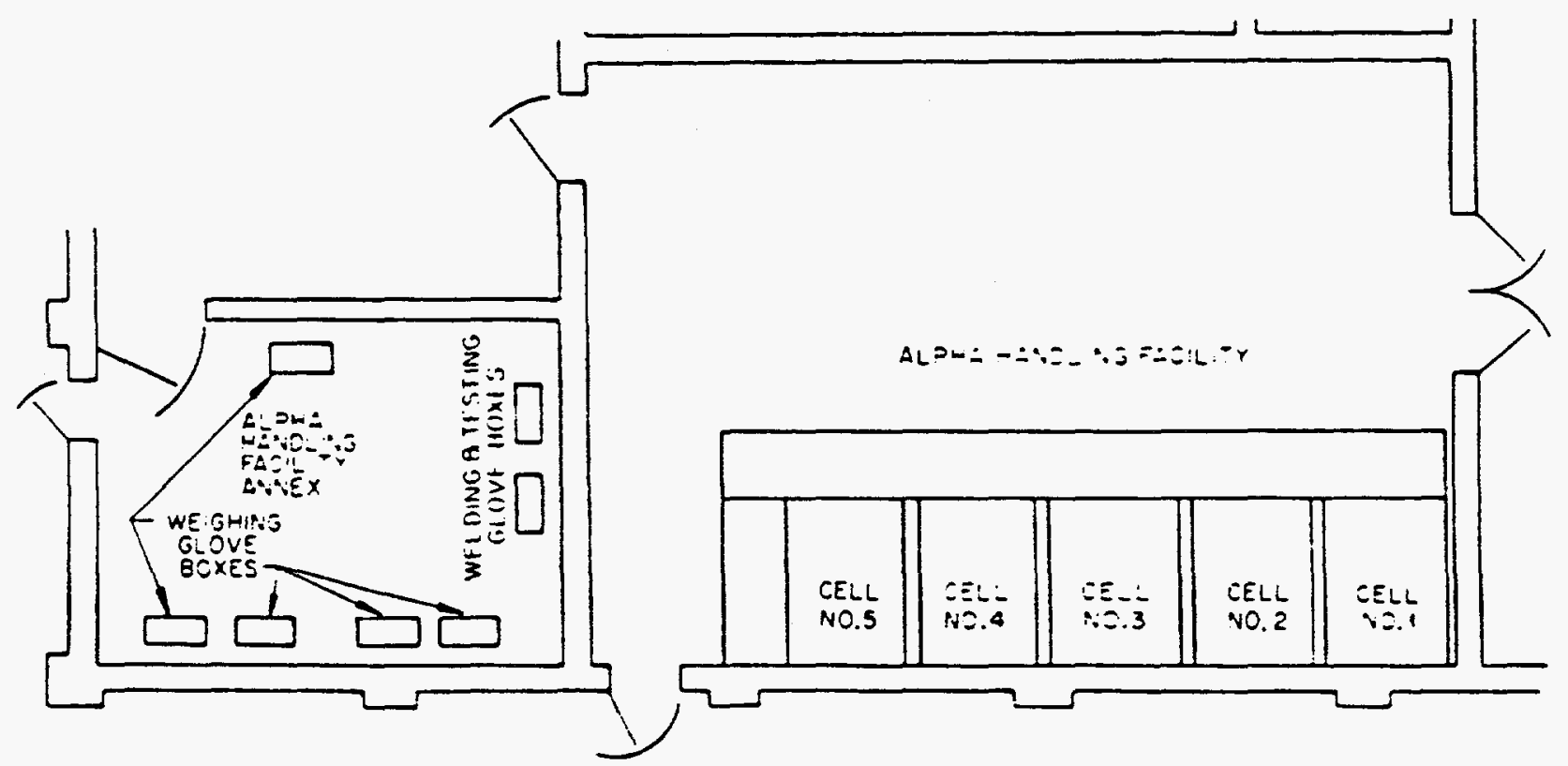

Building 3038-W

Fig. A.13 Floor plan of Alpha Handling Facility in Building 3038. 


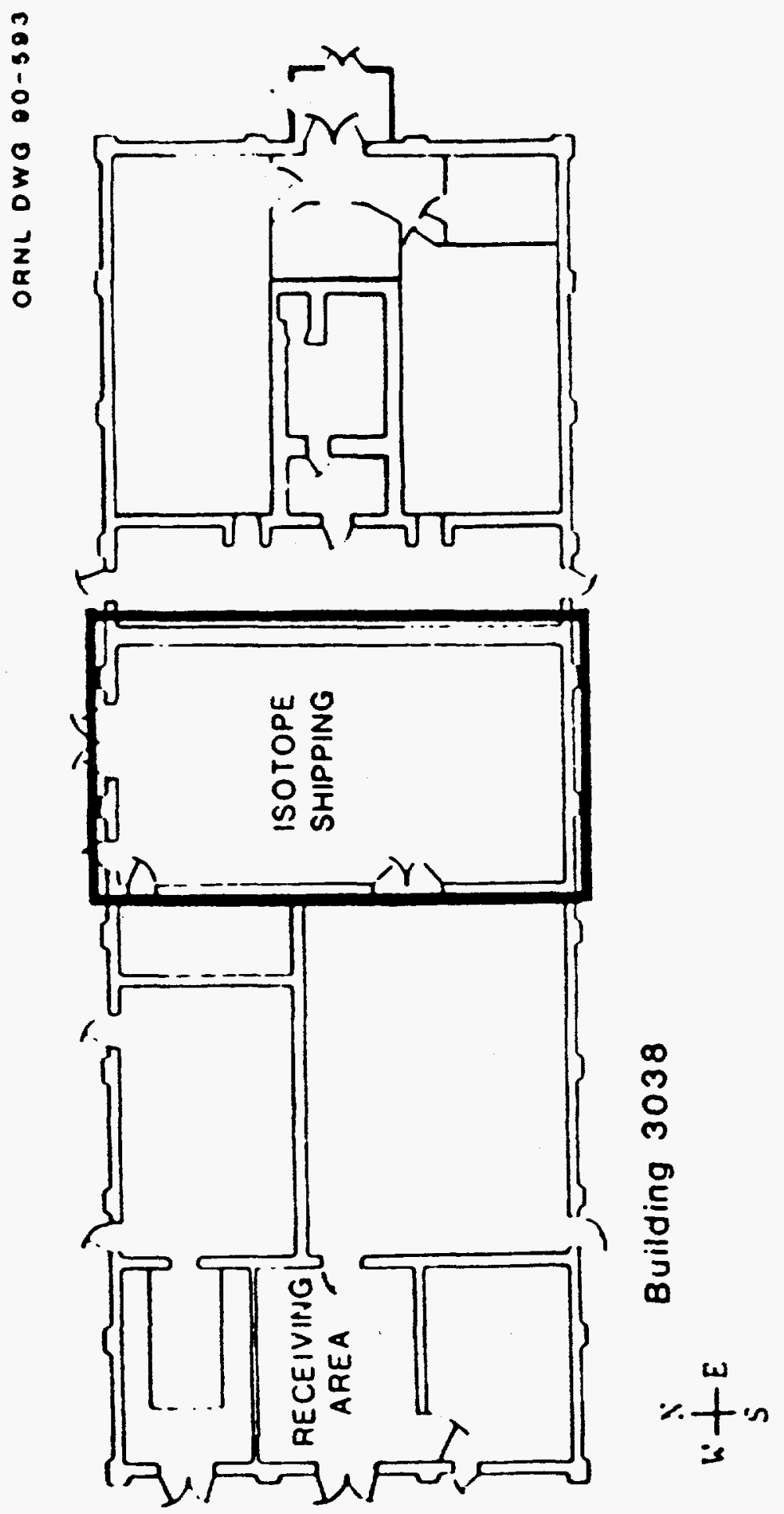


As the volume of radioisotopes being shipped decreased in the 1960s, the shipping area was reduced. In 1968, the west portion was converted into the AHF by adding water-shielded hot cells and glove boxes for fabrication of targets.

The section of the building called $3038-\mathrm{M}$ has always been the radioactive shipping operation for ORNL. Most of the shipments were for the isotopes sales program, but shipments of radioactive materials from other ORNL groups were also handled here. The glove boxes in the AHF annex were used for loading out of isotopes for sales.

The analytical chemistry laboratories supporting isotopes sales were located in the east end until 1976. When the analytical function was transferred to other ORNL facilities, the east end was converted into an isotopes production and development facility. In the late 1970 s and early 1980 s, a research program on plutonium alloys and compounds was conducted in the area which was funded by the DOE Office of Basic Energy Sciences. The same glove boxes were used in the mid 1980s to perform research with the Solid State Division on 147Pm-doped crystals and glasses for laser development studies funded by Lawrence Livermore National Laboratory. With these two exceptions, all work in this end of the facility has been dedicated to isotopes efforts.

\section{A.2.8.3 General Status}

Packaging, shipping, and receiving are ongoing activities in Building 3038. However, the plan is to relocate these activities to other ORNL facilities. Yttrium-90 production was terminated on September 30, 1990. There are no operations in the east-end laboratories. Barricade operations are discontinued, and all existing inventory has been removed.

The general status of the facilities is summarized in Table A.10.

\section{A.2.9. BUILDING 3047-RADIOISOTOPES DEVELOPMENT LABORATORY}

\section{A.2.9.1 Description}

The Radioisotopes Development Laboratory, Building 3047, is a three-story steelframe building with concrete block exterior and interior walls. It is located in the north-central area of Isotopes Circle. Building 3047 is joined to the Isotopes Technology Building, Building 3047-A. Because they have individual ventilation systems and are separated by at least two sets of double doors, they are considered separate buildings. (Building 3047-A, which contains administrative offices, is not part of the deactivation plan.)

The Radioisotopes Development Laboratory houses four high-level beta-gamma cells, one alpha hot cell, seven laboratories for handling low-level materials, a decontamination room, offices, and service areas. The building plan is shown in Fig. A.15. 
Table A.10. Building 3038-general status of facility

Facility/area

Comments

\section{Building}

Type

Main structural components are cast, reinforced concrete connected by girders with nonreinforced masonry walls. Building interior is subdivided by concrete block walls into separate facilities.

\section{Roof and}

exterior walls

Good condition.

Building containment and ventilation

The building rooms and equipment are maintained in a "contained" condition; for the operating areas of the building, a minimum of 0.3 in. w.g. negative relative to the outside atmosphere is required.

ORNL cell ventilation system: room air, glove boxes, hoods, and the $90 \mathrm{Y} /{ }^{90} \mathrm{Sr}$ cell in the east area. Glove boxes and hoods in east area are equipped with single-stage HEPA filter on exhaust; single-stage roughing filter on $90 \mathrm{Y} / 90 \mathrm{Sr}$ hot cell; no filters in duct from hoods. Exhaust air routed to unshielded filter house on roof equipped with parallel banks of testable HEPA filters (double-stage filtration) with bypass provisions during maintenance. Exhaust to 3039 stack.

Local ventilation system: room air exhaust from 3038-M and 3038-W, and hood exhaust from Isotopes Technology Low-Level Laboratory. In the shipping area, ventilation air sweeps from the room over the barricade and through one stage of roughing filters before discharge to filter house on the roof. Room exhaust from the AHF and the AHF annex equipped with single-stage HEPA filters in the duct. Exhaust to filter house on roof equipped with parallel banks of testable HEPA filters (single-stage filtration). Discharge via short stack on roof. 
Table A.10 (continued)

Facility/area

Comments

Building (continued)

Building containment and ventilation (continued)

Liquid waste systems

Monitoring

East-End Laboratories

ORNL process off-gas system: Cells $1,2,3,4$, and 5 and glove boxes in AHF annex; HEPA filter in each cell and glove box. Exhaust passes through second stage of HEPA filters in the AHF before discharge to isotopes area process off-gas system; scrubber and additional HEPA filtration 3039 stack facility.

Air locks: east end has air locks; personnel access to RAMSPAC also has an air lock; other access entries do not have air locks; leads to upsets in contained condition.

Heating and cooling: several systems.

Chilled water unit that serves AHF annex has contamination in it. System not in use.

3038-E and 3038-M have no functioning "hot" drains; drains to LLLW system sealed to prevent use. Includes small hot cell in the west end, the barricade, and several bench and sink drains.

3038-W: alpha handling cells drain to WC-2 system; low-level laboratories on process waste system.

Facility Radiation and Contamination Alarm System, central system for building; monitored at the WOCC.

Nuclear materials stored in a locked safe in metal containers. 
Table A.10 (continued)

Facility/area

Comments

\section{East-End Laboratories \\ (continued)}

East-end, north laboratory
Rolling-mill box: highly alpha contaminated and weighs several tons. Requires the removal of several comer blocks of a nearby wall for adequate clearance if the glove box is removed

Reduction distillation box: relatively new box ( 1 year old), highly contaminated with $244 \mathrm{Cm}$ and $241 \mathrm{Am}$. Includes a cryogenic high-vacuum pump and oil-filled roughing pump.

Press box: highly alpha contaminated and contains a hydraulic press connected to a hand pump outside the box. Can be disposed of at any time.

Loading box: small Lexan box used for loading 147Pmdoped crystals and glasses into quartz spectrophotometer cells. Box contains very slight beta contamination.

East general-purpose hood: highly alpha contaminated and also contains some beta contamination. A highvacuum system is mounted external to the hood with a feed-through into the hood for a bell jar. The damper on this hood must be operated manually.

West general-purpose hood: highly alpha contaminated; also contains possible old, beta contamination. A rolling-mill drive train is mounted outside the hood to accommodate a small rolling mill in the hood.

Weigh box: small, highly alpha-contaminated glove box containing an analytical balance for weighing $\mathrm{Pu}, \mathrm{Am}$, and $\mathrm{Cm}$. 
Table A.10 (continued)

Facility/area

Comments

East-End Laboratories

(continued)

East-end, south laboratory (continued)

$\mathrm{Pu} / \mathrm{Pm}$ glove boxes: two glove boxes joined together by a gloved antechamber. The east box contains a hightemperature vacuum furnace mounted in the floor with an externally mounted, sealed vacuum system. Cooling water is supplied by a recirculating chiller system. Boxes were capable of operating on an inert-gas recirculation system. The west box once contained an elaborate high-temperature, vacuum experimental apparatus which has been stripped out. These boxes were used for $\mathrm{Pu}$ oxide and metal studies in the late 1970 s and early 1980s. In the mid 1980s, they were used for $147 \mathrm{Pm}$-doping studies and are, therefore, highly contaminated with alpha and pure beta emitters. Unfortunately, the boxes would be very difficult to separate, making removal of the entire assembly very difficult.

East hood: alpha and beta contamination is present from a variety of handling operations and from counting. Stainless steel vacuum chambers used for alpha counting extend through the floor of the hood and are evacuated by an oil-filled roughing pump.

Potential for inadvertent spread of ${ }^{\infty} \mathrm{S} / \mathrm{S}^{\infty} \mathrm{Y}$ contamination from adjacent ${ }^{\circ 0} \mathrm{Y}$ laboratory. Sole personnel access to "Y laboratory. Only contamination monitor for ${ }^{\text {OO }} \mathrm{Y}$ personnel located in east foyer of IRML area, which could result in spread of "Sr/ ${ }^{\circ} \mathrm{Y}$ contamination before it was detected. Personnel monitors removed from ${ }^{9} Y$ laboratory exit to east-end, south laboratory. 
Table A.10 (continued)

QY Laboratory

Manipulator cell: highly beta/gamma contaminated with ${ }^{90} \mathrm{Sr} /{ }^{90} \mathrm{Y}$; hot drain shutdown; no wash down provision; shine through manipulator boot opening on top of cell.

Appendage to manipulator cell: used to store old cyclotron plates.

Glove box: contaminated; no wash down provision.

Three hoods: used for tritium trap decontamination; medical (short-lived) isotopes.

RAMSPAC

Barricade inventory removed. There is no drain (capped off) for decontamination of a known spill. The barricade area is open to the room air.

$\underline{\mathrm{AHF}}$

Five alpha cells: contaminated; contain no inventory; windows heavily clouded brown from microorganism growth.

Hot drains: drain to tank WC-2.

West wall: alpha glove boxes were once located there but have been removed.

AHF Annex

Five boxes are highly alpha contaminated with actinide products $\left({ }^{241} \mathrm{Am},{ }^{277} \mathrm{~Np}\right.$, and $\left.{ }^{20} \mathrm{Pu}\right)$.

Two glove boxes used for welding and inspection; no powder handling.

Glove boxes constructed with rubber gaskets (rather than welded stainless steel construction).

Receiving Area

Chilled water unit contaminated. 
ORNL DWC $90-630$
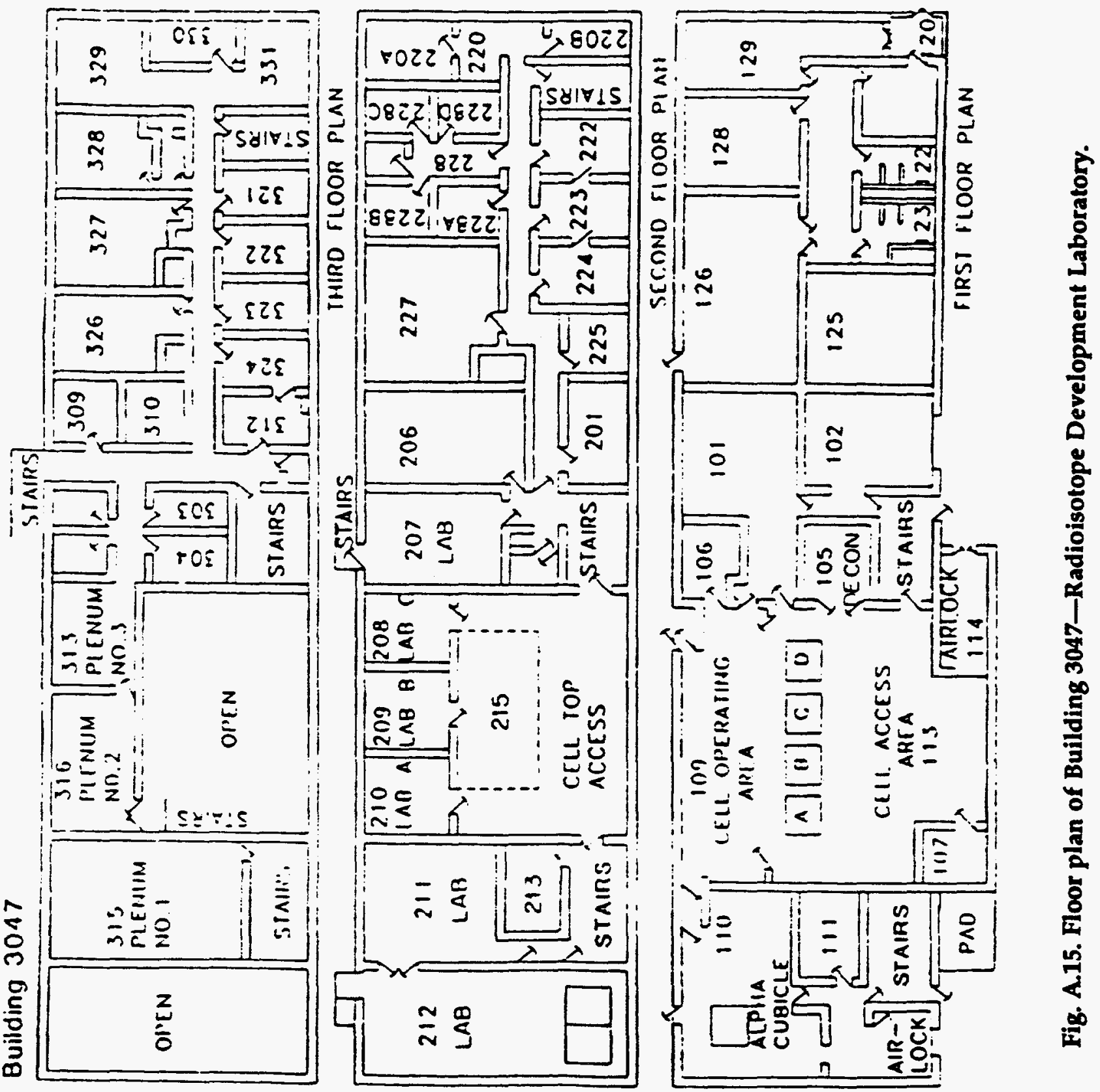


\section{A.2.9.1.1 Beta-gamma cells and support areas}

The four beta-gamma manipulator hot cells (Cells A, B, C, and D), the operating area (Room 109), the cell access area (via rear access doors into the cells; Room 113), and the decontamination room (Room 105) are located on the first floor in the center of the building. The cell access area (via roof hatches into the cells; Room 215) is on the second floor. The walls and tops of Cells A, B, and D are fabricated of $3 \mathrm{ft}$ of barytes concrete. The roof plug and front and rear walls of Cell $C$ are fabricated of $2 \mathrm{ft}$ 3 in. of barytes concrete and 9 in. of steel plate. All interior walls between the cells are of 16-in.-thick laminated steel plate. Cell C has a 21-in.-thick laminated steel access door. The cells are lined with stainless steel. Each cell has a mineral oil-filled, leadglass window arranged to give shielding equivalent to the cell walls. Windows are accessible for maintenance only from the hot side of the cell. Small quantities of materials and some equipment limited to less than $50 \mathrm{lb}$ and $12 \times 12 \times 12$ in. size can be transferred using a conveyor system, which terminates in loading/unloading cubicles at the east and west ends of the cell block. The transfer cubicles have a viewing window. Roof plugs in the top of the cells are located on the second floor to allow the movement of heavier equipment into and out of the cells. Equipment and materials may be transferred between Rooms 113 and 215 through a gasketed hatch. Steam, air, electrical, and water services are headed off the utilities services above the operating corridor and penetrate the cell operating face with an isolating valve or switch provided. Radioactive services (cell exhaust, hot drain, and process off-gas) penetrate the cell block through underground headers.

\section{A.2.9.1.2 Alpha hot cell}

A manipulator hot cell for handling alpha emitters is located in Room 110. The cell is shielded by water-filled, reinforced steel tanks that provide water shielding on all four sides and the top. The cell has a welded stainless steel liner and a water-filled viewing window. A glove box attached to the vacuum access port provides bagin/bag-out capability for introducing/removing materials. The cell may be evacuated and operated under an inert atmosphere. The shield tank on the rear (west) side of the cubicle is movable to permit access to an opening equipped with a removable cover that contains glove ports and a viewing window.

\section{A.2.9.1.3 Second-floor laboratories}

There are six laboratories on the second floor: four are used for nuclear medicine research, one (Room 211) for ${ }^{14} \mathrm{C}$, and one laboratory (Room 212) was in the process of renovation when the decision was made to shut down the facility.

\section{A.2.9.1.4 Building containment and ventilation}

The building is divided into three zones: the west-end (alpha) containment zone, the middle (beta-gamma) containment zone, and the east (office) zone, which does not have containment. Each zone has a separate ventilation system with individual blowers for each system. 
The manipulator cells, glove boxes, and hoods constitute the primary containment of radioisotopes, with the designated "containment" areas within the building providing secondary containment. All entries to "contained" areas are provided with an air lock and are gasketed to minimize inleakage. There are also air locks between the alpha and the beta-gamma containment zones.

The west-end containment zone includes the three alpha laboratories-Rooms 110,211 , and 212. These laboratories are maintained in a "contained" condition of at least 0.30 in. w.g. negative pressure with respect to the outside atmosphere. Room air is filtered and recirculated with a limited discharge to the atmosphere. The exhaust goes to a filter house on the roof where an exhaust fan draws air through HEPA filters (single-stage filtration) and discharges to a short stack on the roof.

The middle (beta-gamma) containment zone includes the hot cell operating and access areas (Rooms 109, 113, and 215), the decontamination room (Room 105), and three low-level laboratories (Rooms 208, 209, and 210). The middle section of the building operates at a small negative pressure relative to the outside atmosphere and automatically goes into containment $(-0.3$ in. w.g.) if the instrumentation detects radioactivity. Room air exhaust is routed to a filter house (single-stage HEPA filtration) on the roof and is discharged to a short roof stack.

The east end of the building does not have containment, and there are no filters on the room air exhaust to the atmosphere. This area includes offices, change rooms, service areas, and one low-level laboratory (Room 207).

Ventilation for the beta-gamma cells is provided by the isotopes area cell ventilation system and the 3039 stack. There are two stages of HEPA filters: one stage in each cell and a second stage in the shielded filter house on the south wall of the first floor. Ventilation for the alpha cell is provided by the process off-gas system. There are one stage of HEPA filtration in the alpha cell, a second set of HEPA filters in Room 110, and a scrubber and additional HEPA filters at the 3039 stack. The ventilation for hoods and glove boxes is outlined under the individual laboratories in Sect. 2.9.3.

\subsubsection{History}

Building 3047 was constructed in approximately 1962 and was used to conduct research and development and to produce radioisotopes.

\subsubsection{General Status}

Isotopes (Chemical Technology Division) activities are shut down, except for waste removal and transloading of radioactive material in the beta-gamma hot cells.

The general status of this facility is summarized in Table A.11. 
Table A.11. Building 3047-general status of facility

\section{Building}

Type

\section{Roof and \\ exterior walls \\ Building containment and ventilation}

Steel frame with concrete block walls and interior partitions.

Good condition.

Three building areas: the west (alpha) containment zone, the middle (beta-gamma) containment zone, and the east (office) area, which does not have containment. Separate blowers for each zone. Air locks provided at entrances to containment zones and between the middle and west zones.

West (alpha) containment zone:

- includes Laboratories 110, 211, and 212;

- operates continuously in a "contained" condition of at least 0.30 in. w.g. negative pressure with respect to outside atmosphere;

- air is filtered and recirculated with limited room air exhaust; and

- local system exhaust for room air to filter house on roof (single-stage HEPA filtration), discharge to short roof stack.

Middle (beta-gamma containment zone:

- includes cell operating area (Room 109), cell access area (Room 113), cell top access (Room 215), the decontamination room (Room 105), and three lowlevel laboratories (Rooms 208, 209, and 210);

- operates under a small negative pressure with respect to outside atmosphere, is automatically placed into "containment" if instrumentation detects radioactivity; and

- local system exhaust to filter house on roof (singlestage HEPA filtration), discharges to short roof stack. 
Table A.11 (continued)
Facility/area
Comments

\section{Building (continued) \\ Building contamination and ventilation (continued)}

Liquid waste systems

Monitoring

\section{First Floor}

Cells A and B (beta-gamma cells)
East (office) wing, not "contained":

- includes offices, change rooms, service areas, and one low-level laboratory (Room 207); and

- not equipped for "containment," no filters on building air exhaust, local ventilation system.

Beta-gamma cells: isotopes area cell ventilation system; single-stage HEPA filtration in cells, exhaust to filter house (single-stage HEPA filtration; total of two stages of filtration) on south wall of first floor and 3039 stack.

Alpha hot cell: process off-gas system; in-cell single HEPA filtration, second set of HEPA filters in Room 110, exhaust to scrubber and additional filters at 3039 stack.

Cell floor drains and some hoods: drain to tank WC-10.

Some hoods: process waste system.

Facility Radiation and Contamination Alarm System: locally alarming monitors, central alarm panel for building; monitored at the WOCC.

Cells are relatively "clean"; contamination levels below 3000 counts/min, average; radiation levels below $300 \mathrm{mR} / \mathrm{h}$ average; can open back doors of Cells A and B to transfer large items.

Ventilation: isotopes area cell ventilation system; single-stage HEPA filtration in cell; exhaust to filter house (single-stage HEPA filtration; total of two stages) and 3039 stack.

Hot drain to tank WC-10. 
Table A.11 (continued)

Facility/area

Comments

First floor (continued)

Cells $A$ and $B$

(beta-gamma cells)

(continued)

HEPA-filtered process off-gas service.

Electrical services.

Lighting good.

1-ton air hoist.

Cell C

(beta-gamma cell)

Contamination and radiation levels assumed to be high ${ }^{(152} \mathrm{Eu},{ }^{154} \mathrm{Eu},{ }^{60} \mathrm{Co}$ and $\left.{ }^{158} \mathrm{Gd}\right)$.

Ventilation: isotopes area cell ventilation system; single-stage HEPA filtration in cell; exhaust to filter house (single-stage HEPA filtration) and 3039 stack.

Hot drain to tank WC-10.

No electrical services.

No lighting.

Cell window cloudy; oil in window leaking.

Air hoist (1-ton) nonfunctional.

\section{Cell D}

(beta-gamma cell)

Highly contaminated with ${ }^{60} \mathrm{Co}$ contamination level below 30,000 counts $/ \mathrm{min}$ radiation level range 1 to $900 \mathrm{R} / \mathrm{h}$.

Ventilation: isotopes area cell ventilation system; single-stage HEPA filtration in cell; exhaust to filter house (single-stage HEPA filtration) and 3039 stack.

Hot drain to tank WC-10.

HEPA filtered process off-gas service.

Electrical services nonfunctional; through cell penetrations only. 
Table A.11 (continued)

Facility/area

Comments

First Floor (continued)

Cell D (continued)

(beta-gamma cell)

Lighting fixtures nonfunctional due to radiation damage; "drop cord" only.

Cell window cloudy and leaking oil.

Bottom of pit (cell ventilation sump) is located $14 \mathrm{ft}$ below working area and contains sludge $(900 \mathrm{R} / \mathrm{h})$; current manipulators cannot reach into pit; need special tools and equipment.

Air hoist (1-ton) nonfunctional.

Alpha hot cell

(Room 110)

Contamination level above $1,000,000 \mathrm{dpm}$; radiation level unknown.

Ventilation: process off-gas system; in-cell single-stage HEPA filtration with bypass provision during maintenance; routed to second stage of HEPA filters in Room 110; exhaust to scrubber and additional HEPA filters at 3039 stack.

Hot drain to tank WC-10.

Glove ports in rear of cell.

Entry box with electrical services attached; electrical not leaktight; use care to keep entry box dry during cell wash down. In addition, gaskets leak where entry box is attached to cell.

Attached entry box can be vented through the alpha cell to the process off-gas system by opening the door (current practice) or to the cell ventilation system (valve presently closed). 
Table A.11 (continued)

Facility/area

Comments

First Floor (continued)

${ }^{153} \mathrm{Gd}$ glove box

(Hood; Room 113)

Used for ${ }^{150} \mathrm{Gd}$ powder pressing.

Ventilation: glove box is a static glove box with no ventilation. Glove box is vented to hood through a single HEPA filter.

Manipulators installed in lead-shielded box face.

One ${ }^{150} \mathrm{Gd}$
glove box hood
(Room 113)

Decontamination facility
Contamination level below $200 \mathrm{dpm}$.

Ventilation: isotopes area cell ventilation system; singlestage HEPA filtration on box; exhaust to filter house (single-stage HEPA filtration) and 3039 stack.

Drain to process waste system.

Electrical service.

Lighting good.

Shower:

- contamination level below $200 \mathrm{dpm}$; and

- drain to tank WC-10.

Enclosed sink:

- contamination level below $3500 \mathrm{dpm}$;

- ventilation: isotope area cell ventilation system, exhaust to filter house (single-stage HEPA filtration) and 3039 stack; and

- drain to tank WC-10.

Sample hood:

- contamination below $1000 \mathrm{dpm}$;

- Ventilation: isotope area cell ventilation system, single HEPA filtration on hood, exhaust to filter house and 3039 stack;

- drain to tank WC-10; 
Table A.11 (continued)

Facility/area

Comments

First Floor (continued)

Decontamination

facility

(continued)

Sample hood (continued):

- electrical service; and

- lighting good.

Second-Floor Laboratories

Room 207

Laboratory used for nuclear medicine research.

Four hoods, three with process waste system drains and one with hot drain to tank WC-10.

Ventilation: east (office) wing local ventilation system; no filters on room air exhaust; status of hoods could not be confirmed.

Room 208

Laboratory used for nuclear medicine research.

One enclosed hood with glove ports and hot drain to tank WC-10.

One standard hood with process waste drain.

Ventilation: middle (beta-gamma) containment zone; local ventilation system; room air and hoods exhaust to filter house with single-stage HEPA filtration and short roof stack.

Room 209

Laboratory used for nuclear medicine research.

One enclosed hood with glove ports and hot drain to tank WC-10.

One standard hood with process waste drain.

Ventilation: middle (beta-gamma) containment zone; local ventilation system; room air and hoods exhaust to filter house with single-stage HEPA filtration and short roof stack. 
Table A.11 (continued)

Second-Floor

Laboratories (continued)

Room 210

Room 211

Room 212
Laboratory used for nuclear medicine research.

Three hoods: one with process drain, one with hot drain to tank WC-10, one three-fourths enclosed with no services.

Ventilation: middle (beta-gamma) containment zone; local ventilation system; room air and hoods exhaust to filter house with single-stage HEPA filtration and roof stack.

Equipment contaminated with ${ }^{14} \mathrm{C}$; small quantity of ${ }^{14} \mathrm{C}$ stored in room. May be residual alpha contamination.

Four modified glove boxes; two with hot drains to tank WC-10.

Ventilation: west (alpha) containment zone; local ventilation system; room air and glove boxes exhaust to filter house (single-stage HEPA filtration) and short roof stack.

Equipment storage.

Ventilation: west (alpha) containment zone; local ventilation system; room air exhausts to filter house (single-stage HEPA filtration) and short roof stack. 


\section{A.2.10 BUILDING 3517-FISSION PRODUCT DEVELOPMENT LABORATORY}

\section{A.2.10.1 Description}

Building 3517, the Fission Product Development Laboratory (FPDL), was constructed (1) to recover long-lived fission products (e.g., ${ }^{\circ 5} \mathrm{Sr},{ }^{137} \mathrm{Cs}$, and ${ }^{14} \mathrm{Ce}$ ) from aqueous wastes generated in reprocessing irradiated reactor fuel elements, (2) to purify feed materials from other DOE sites, and (3) to prepare radioactive sources. It is located in the central ORNL site, southwest of the Isotopes Circle facilities.

Building 3517 is a three-story, braced steel framework structure with metal deck roofs and 12-in. non-reinforced-concrete masonry walls on the lower two stories. The building is about $120 \mathrm{ft}$ long (east-west), and the first two stories are about $60 \mathrm{ft}$ wide (north-south) and $27 \mathrm{ft}$ high. A third story, about $27 \mathrm{ft}$ wide by $16 \mathrm{ft}$ high, runs the length of the building east-west. This third story, referred to as the crane bay, supports a 20-ton bridge crane and services the top access plugs to Cells 1 through 15 . The crane bay has aluminum siding.

\section{A.2.10.1.1 Cells}

The FPDL contains manipulator and process cells for producing radioactive sources and associated operating, service, office, and personnel access areas. The general layout of the first and second floors is presented in Fig. A.16, and a description of the cells is given in Table A.12. The main cell block, Cells 1 through 15 , is a double cell block located on the first level. These hot cells are massive, steelbar reinforced concrete boxes with wall thicknesses of 3 and $4 \mathrm{ft}$. The access to the cells consists of removable reinforced concrete blocks in the tops of the cells. Each individual cell within the hot-cell structure is isolated by 2-ft-thick concrete walls. Both the hot cells and the building are founded either on rock or on graded gravel close to rock. The four tank farm cells, 21 through 24, are located underground adjacent to the building. There is no Cell 19; it was removed. The process cells, storage cells, and high-level manipulator cells are shielded from the nearest accessible area by the equivalent of $4 \mathrm{ft}$ of ordinary concrete. The low-level manipulator cells and service areas have less shielding (Table A.12.). Cells 1 through 15 have stainless steel linings to facilitate decontamination. Cells 16 and 17, the service cells, and the tank farm cells have Amercoat coatings.

Cells 1 through 9 in the north row of the main cell block were process cells with no viewing windows. Except for the north side of Cell 1, which has been used for decontamination, these cells have been inactive since 1975. Some equipment has been removed, but Cells 4 through 7 still contain a variety of tanks, piping, samplers, services, and instrumentation. A service tunnel runs along the north side of the cell bank.

Cells 10 through 15, the south row of the main cell block, are manipulator cells for handling high-level beta-gamma radioisotopes. They are equipped with viewing windows. Cells 10 and 14 are divided by steel plate into Cells $10 E$ and $10 \mathrm{~W}$ and Cells $14 \mathrm{E}$ and $14 \mathrm{M}$. The manipulator cells have interconnecting shielded doors to enable materials to be passed from one cell to another. All except the large door 

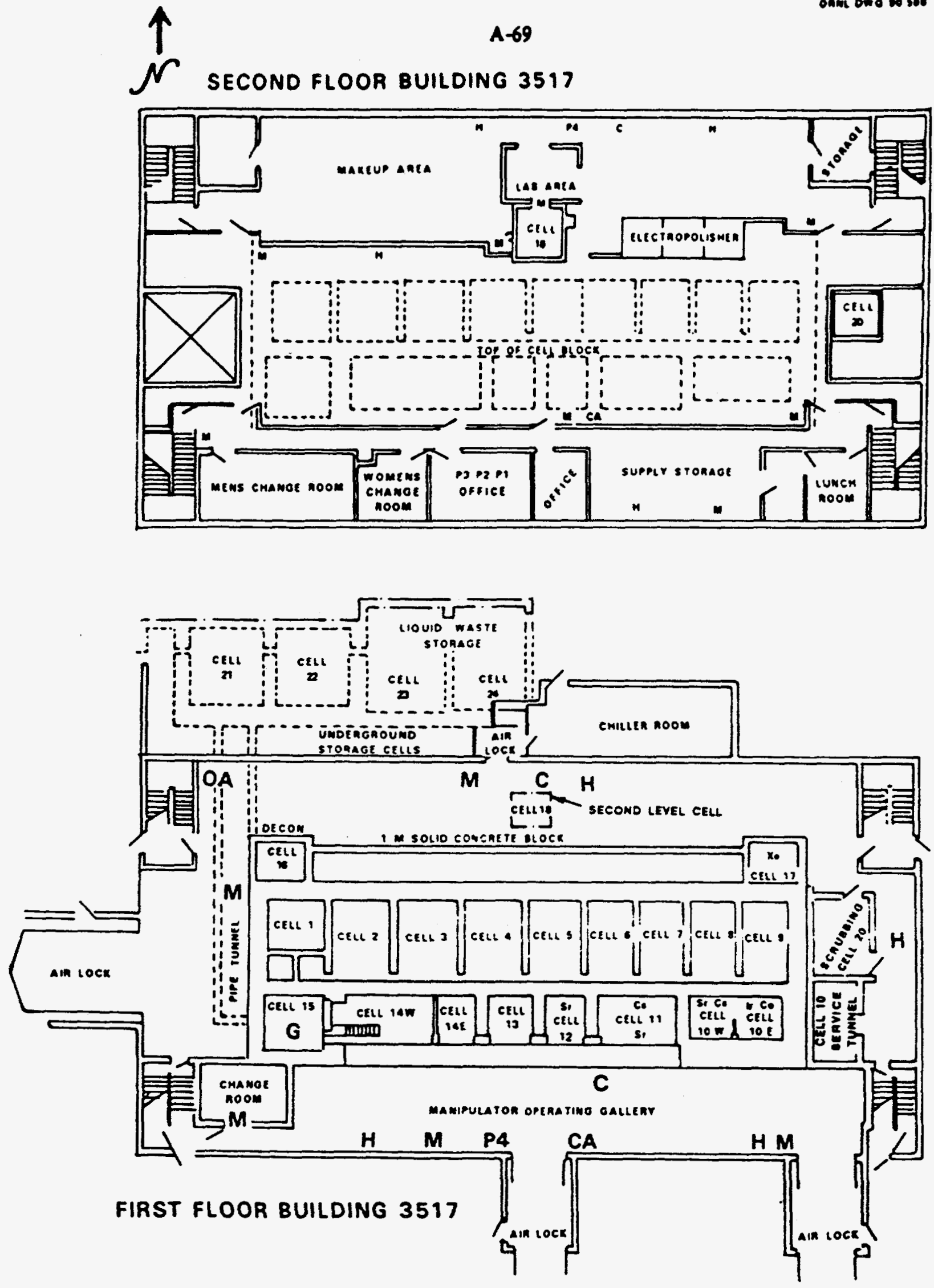

Fig. A.16. Floor plan of Building 3517-Fission Product Development Laboratory. 
Table A.12. Building 3517-cell descriptions

\begin{tabular}{|c|c|c|c|c|c|}
\hline \multirow[b]{2}{*}{ Cell type } & \multirow[b]{2}{*}{ Cell No. } & \multicolumn{3}{|c|}{ Dimensions ( $\mathrm{ft}$ ) } & \multirow{2}{*}{$\begin{array}{l}\text { Minimum equivalent } \\
\text { standard concrete } \\
\text { shielding for walls ( } \mathrm{ft} \text { ) }\end{array}$} \\
\hline & & $\overline{L^{\circ}}$ & $W^{*}$ & $D^{\circ}$ & \\
\hline Process & 1 & 9 & 125 & 12 & 3 \\
\hline Process & 2 & 9 & 12.5 & 12 & 4.5 \\
\hline Process & 3 & 9 & 125 & 12 & 4.5 \\
\hline Process & 4 & 9 & 125 & 12 & 4.5 \\
\hline Process & 5 & 9 & 125 & 12 & 4.5 \\
\hline Process & 6 & 7.5 & 125 & 12 & 4.5 \\
\hline Process & 7 & 7.5 & 12.5 & 12 & 4.5 \\
\hline Process & 8 & 75 & 12.5 & 12 & 45 \\
\hline Process & 9 & 7.5 & 125 & 12 & 4.5 \\
\hline Manipulator & 10 & 7.5 & 7 & 14 & 4 \\
\hline Manipulator & 11 & 13 & 8 & 11 & 4 \\
\hline Manipulator & 12 & 7 & 8 & 11 & 4 \\
\hline Manipulator & 13 & 7 & 8 & 11 & 4 \\
\hline Manipulator & 14 & 6.5 & 8 & 12 & 4.5 \\
\hline Manipulator & 15 & 10 & 4 & 16 & 2 \\
\hline Manipulator & 16 & 8 & 6 & 14 & 1 \\
\hline Service & 17 & 8 & 6 & 14 & 1 \\
\hline Manipulator & 18 & 6 & 6.5 & 10.5 & 1.5 \\
\hline Service & 20 & 6.5 & 75 & 12 & 1 \\
\hline Tank farm & 21 & 25 & 12 & 14 & 4 \\
\hline Tank farm & 22 & 25 & 12 & 14 & 4 \\
\hline Tank farm & 23 & 30 & 12 & 14 & 2 \\
\hline Tank farm & 24 & 30 & 12 & 14 & 25 \\
\hline
\end{tabular}

\footnotetext{
' $L=$ length; $W=$ width; $D=$ depth.
}

"Cells 1-9, 10W, and 11-13 have two layers of 2-ft-thick, reinforced-concrete blocks in the top of the cell; total thickness of top equivalent to $5 \mathrm{ft}$ of concrete. Cell 10E has one layer of 4-ft-thick blocks; Cell 14, one layer of 3-ft-thick blocks; and Cell 15, one layer of 2-ft-thick blocks. 
between Cells 14 and 15 can be operated from the manipulator operating gallery. The large door is handled by the overhead crane. (However, a small door between Cells 14 and 15 is operated from the manipulator gallery.) Cask transfers or transfers of large items in or out of the cell block are handled via the cell top plugs using the overhead 20ton crane. Cell 10W has a water-cooled well for storage of radioisotopes capsules. The well is cooled with chilled water with backup from once-through process water. Radioisotopes processing was conducted in the manipulator cells until April 1989, when the facility was placed on standby.

The building contains four additional cells:

- Cell 16-a manipulator cell used for decontaminating equipment,

- Cell 17-used for storage of fission product xenon,

- Cell 18-a manipulator cell (once an analytical cell but piping stripped out), and

- Cell 20-inactivated off-gas scrubber used when process Cells 1-9 were operational.

There is also a currently inactive glove box, which was installed for decontaminating equipment.

There are four underground cells adjacent to the building. Cells 21 and 22 at one time housed storage tanks for fission product solutions. Cell 21 is empty; the tanks and piping have been removed. Cell 22 still contains a tank (inactive) and associated piping. Cells 23 and 24 contain collection tanks for LLLW (Sect. A.2.10.1.3).

\section{A.2.10.1.2 Building containment and ventilation}

The building ventilation is operated in a "containment" mode (at least -0.3 in. w.g. relative to the outside atmosphere), and the cells are maintained at a pressure of at least -0.3 in. w.g. relative to the building pressure. The building is sealed and equipped with air-lock entries for personnel and a truck air lock. Air-lock doors are gasketed. Each operating area is enclosed and can be isolated from other areas of the building, except where piping and conduit come through floor and wall openings. Air flows from areas with lesser potential for contamination to areas of higher potential. Thus, ventilation air flows from the operating areas to the inleakage openings into the cells and the service tunnel. There are roughing filters on the inlets in the service tunnel and Cell 15. Ventilation exhaust flows in reinforced concrete ducts underground to a filter pit outside the building containing a set of testable HEPA filters, to an above-ground enclosure containing a second set of testable filters, and then through to the new filter house containing a third stage of testable HEPA filters. The exhaust is then discharged to the ORNL Building 3039 stack cell ventilation system. All of the exhaust fans are in the 3039 system. Additionally, there are in-cell HEPA filters on the manipulator cells, but these cannot be tested.

\section{A.2.10.1.3 Liquid waste systems}

Radioactive liquid waste drains from the cells and the electropolisher glove box are routed through a common header to stainless steel collection tanks, S-223, S-324, and S523. These tanks are located in shielded underground storage vaults, Cells 23 and 24, located adjacent to the building. The wastes are jetted from the Building 3517 tanks to the ORNL low-level waste (LLW) evaporator facility through a doubly contained stainless steel line after it leaves the outside wall of the building. There is a short section of this line that is not doubly contained. Provisions are being made to beak test this line in accordance with the Federal Facility Agreement. These tanks are in good condition and are contained in a concrete vault; they are vented to the process off-gas system. 
The process waste system receives normal effluent from building sinks and floor drains in operating areas, steam condensate traps, and emergency cooling water from the storage well in Cell $10 \mathrm{~W}$ and provides disposal of nonradioactive liquids (except sanitary waste). The waste is monitored before it is discharged to the ORNL central process waste system. If radioactivity is detected at levels above the limits for process waste, the material is diverted to the LLLW system.

\section{A.2.10.2 History}

FPDL went on line in 1958 to separate kilocurie amounts of fission products from redox- and Purex-type waste streams. The fission product recovery program was successfully demonstrated during the first 2 years of operation, and kilocurie quantities were made available for worldwide distribution. Radioisotopes separated during the early days (late 1950 s and early 1960s) included ${ }^{144} \mathrm{Ce},{ }^{137} \mathrm{Cs},{ }^{90} \mathrm{Sr},{ }^{167} \mathrm{Pm},{ }^{106} \mathrm{Ru}$, and ${ }^{80} \mathrm{Tc}$.

In the early 1960s, the advent of the Systems for Nuclear Auxiliary Power (SNAP) program increased the demand for ${ }^{90} \mathrm{Sr}$ heat sources, as well as the requirements for ${ }^{15} \mathrm{Cs}$, and ${ }^{i 4} \mathrm{Ce}$ sources to megacuries. To meet this demand, fission product concentrates were shipped from the Hanford Atomic Products Operation to FPDL for preparation of the sources for the SNAP program. Under this program, there were three product streams, as follows:

- Semipure ${ }^{137} \mathrm{Cs}$ was purified, converted to cesium chloride powder, cold-pressed into pellets, and the pellets encapsulated.

- Purified ${ }^{9} \mathrm{Sr}$ was converted to strontium titanate, compacted by vacuum hot-pressing into pellets, and the pellets encapsulated.

- Cesium-144 was separated from a mixed rare-earth fraction by solvent extraction and converted to cerium oxide. The powder was cold-pressed and sintered and then sealed in a compatible container.

A total of $10 \mathrm{MCi}$ of fission product material was processed at the FPDL during this operational period. At the conclusion of that program in 1975, the chemical processing cells were shut down and maintained in protective storage. Some initial decontamination was performed, but subsequent funding restrictions limited the scope of this effort. The initial program included the encapsulation and storage of approximately $500,000 \mathrm{Ci}$ of ${ }^{\circ} \mathrm{Sr}$ titanate powder and hot chemical flushes of process equipment and piping within all nine process cells. Some equipment has been removed, but Cells 4 through 7 still contain processing tanks, piping, and equipment and are considered to be very high radiation areas.

Radioisotopes processing continued in the manipulator cells after 1975 at a reduced level of operation until April 1989, when the building was placed in standby. The principal operations during this period involved the production of ${ }^{90} \mathrm{Sr}$ and ${ }^{137} \mathrm{Cs}$ sources from separated product from Hanford.

Other special operations (various short-term periods) include (1) processing of ${ }^{60} \mathrm{Co}$, ${ }^{192} \mathrm{Ir}$, and ${ }^{235} \mathrm{U}$; (2) ${ }^{261} \mathrm{Am}$ target preparation; (3) ${ }^{152} / 156 \mathrm{Eu}$ purification; and (4) separation of ${ }^{\circ} \mathrm{Tc}$ from crude concentrate received from the Paducah Gaseous Diffusion Plant. 


\section{A.2.10.3 General Status}

No radioactive operations are being conducted in Building 3517 except the removal and disposal of some solid and liquid LLW. Daily surveillance is carried out. A programmed maintenance is being conducted. The general status of the facility is summarized in Table A.13. The estimated quantity of contaminated materials (excluding inventory) requiring removal/disposal is given in Table A.14.

\section{A.2.11. BUILDING 7025-TRITIUM TARGET FABRICATION}

\section{A.2.11.1. Description}

Building 7025 is located about 1.4 miles northeast of the central ORNL site. It is within the perimeter fence of the ORNL 7000 area but isolated from other buildings. The structure is a prefabricated, metal-sided building with a total floor area of $590 \mathrm{ft}^{2}$ and a total free space volume of approximately $6000 \mathrm{ft}^{3}$.

The building was used for fabricating titanium tritide targets, for preparing metallurgical samples for helium embrittlement studies by diffusing tritium into the samples and allowing it to decay to helium, and for preparing thin films of $\mathrm{ThO}_{2} / \mathrm{UO}_{2}$ by vacuum evaporation. No aqueous wastes were generated by these processes.

The building layout is shown in Fig. A.17. The tritium equipment is housed in a 26-ftlong stainless steel hood which is exhausted by a $2000-\mathrm{ft}^{3} / \mathrm{min}$ fan. The tritium hood exhaust is not filtered because there are no solid radioactive species to be filtered. A high-vacuum evaporator system was used in the building for the preparation of uranium and thorium targets. The vacuum evaporator was operated in a HEPA-filtered hood for contamination control. Bench-top quantities were handled. 
Table A.13. Building 3517-general status of facility

\section{Building}

Type

Roof and

exterior walls

Building containment and ventilation

Liquid waste systems

Monitoring

Cask handling

Process Cells
Steel frame, first two levels, masonry walls; crane bay, aluminum siding; hot cells, massive steel-bar reinforced concrete boxes.

Good condition.

Building sealed; air locks with gasketed doors; building operates in a "contained" state to maintain at least 0.3 in. w.g. negative pressure relative to the outside atmosphere; air flows from operating areas into the cells; cells exhaust through underground ducts to filter pit outside the building with singlestage HEPA filtration (testable); second-stage HEPA filtration (testable) in above-ground filter hours; third-stage HEPA filtration in new filter house; exhaust to 3039 stack.

Cell floor drains and electropolisher glove-box drain: drain to stainless steel collection tanks (S-223, S-324, and S-523) located in shielded underground cells adjacent to building; wastes jetted to ORNL LLW evaporator facility as necessary.

Building floor drains and sinks, steam condensate, and emergency cooling water for storage well: monitored at Manhole 209 before discharge to ORNL process waste system.

Facility Radiation and Contamination Alarm System: locally alarming monitors; central alarm panel for building; monitored at the WOCC.

20-ton bridge crane; truck air lock, and forklift trucks.

Cells 1-4 used to process ${ }^{\circ 0} \mathrm{Sr}$ (out of service); and Cells 5-8 used to process ${ }^{17} \mathrm{Cs}$ (out of service). 
Table A.13 (continued)

Facility/area

Comments

Process Cells (continued)

Cells $1,2,3,8$, and 9

High radiation area; contamination area.

Cells stripped of tanks and lines; Cells 1 and 9 contain equipment; Cells 2, 3, and 8 are empty.

Manipulator Cells

General comments

for Cells 10-15

Very high radiation area; contamination area. Manipulator boots require frequent changes to maintain confinement.

Cell 10E

Used as a transfer cell; material normally entered into manipulator cells and manufactured sources removed via Cell $10 \mathrm{E}$ top hatch using the overhead crane.

Past experience manipulators were contaminated with ${ }^{\circ} \mathrm{Sr}$ when removed for maintenance.

Removable plug in manipulator room wall to pass small items in.

Electrically operated hoist $(500 \mathrm{lb})$.

Empty.

Cell 10W

Used as storage cell.

Inventory: ${ }^{90} \mathrm{Sr}, \quad 22,000 \mathrm{Ci}$; ${ }^{137} \mathrm{Cs},-88,000 \mathrm{Ci}$; and ${ }^{24} \mathrm{Cm},-450 \mathrm{~g}$.

Past experience shows that manipulators were contaminated with ${ }^{\circ 0} \mathrm{~S} r$ when removed for maintenance.

Water-cooled storage well for storage of radioisotope capsules; chilled-water cooling with backup from once-through process water. 
Table A.13 (continued)

Facility/area

Comments

Manipulator Cells (continued)

Cell 10W (continued)

Air-operated hoist (1000 lb).

Capsule welding machine.

Cell 11E and 11W

Highly contaminated with ${ }^{\circ 0} \mathrm{Sr}$ and ${ }^{137} \mathrm{Cs}$. Past experience shows that manipulators were contaminated with ${ }^{\circ} \mathrm{Sr}$ and ${ }^{13 "} \mathrm{Cs}$ when removed for maintenance.

East and west windows are cloudy.

Cell 12

Highly contaminated with ${ }^{90} \mathrm{Sr}$ and ${ }^{137} \mathrm{Cs}$. Past experience shows that manipulators were contaminated with ${ }^{90} \mathrm{Sr}$ and ${ }^{137} \mathrm{Cs}$.

Window in good condition; water lines cut off; no electrical service; hot drain may be plugged with glass and/or lead shot, and/or trash but could not be confirmed.

Cell 13

Highly contaminated with ${ }^{15} \mathrm{Cs}$.

Window leaking; hot drain may be plugged with glass and/or lead shot, and/or trash but could not be confirmed.

Cell 14E

Highly contaminated with ${ }^{15} \mathrm{Cs}$; may find ${ }^{13} \mathrm{Cs}$-glass.

Window leaks and is cloudy; no electrical service.

Left manipulator presently shielded with lead blankets around through tube opening. In 1979, manipulator repair, ${ }^{137} \mathrm{Cs}$ powder observed in pull bag and manipulator at high radiation readings. Manipulator will probably need to be pushed into cell and replaced.

Cell 14M and 14W

Used as waste transfer cell. 
Table A.13 (continued)

Facility/area

Comments

\section{Manipulator Cells (continued)}

Cell 15

Used to load LLW out of the manipulator cell block. LLW is normally removed via cell top hatch using the overhead crane.

Lower contamination.

Electric hoist for operating small door between Cells 14 and 15.

Cell 16

Decontamination cell (inactive).

Can be entered by personnel.

Limited transferable contamination; may find alpha contamination in cracks.

Cell 18

Former analytical cell; all piping removed; still a very high radiation area; contamination area.

Empty.

Service Cells and

Service Tunnels

Cell 17

Used for storage.

Inventory of stored xenon isotopes contaminated with trace levels of " ${ }^{\mathrm{K}} \mathrm{K}$; stored in gas cylinders.

Cell 20

Off-gas scrubber (inactive) used when all cells were operational.

Roughing filters (operational) for cell ventilation system located in pump compartment.

Pump compartment: general area of $200 \mathrm{mR} / \mathrm{h}$.

Scrubber compartment: very high radiation area. 
Table A.13 (continued)

Facility/area

Comments

Service Cells and

Service Tunnels (continued)

Service tunnel

(for process cells)

Service tunnel for Cell 10

Cell21 (tank farm)

Cell 22 (tank farm)

Operating and

Service Areas

Manipulator-operating gallery
High radiation area; airborne radioactivity area; contamination area (but can work in area with protective equipment); almost all "Sr; airborne radioactivity generated with any activity in area; "hot" spot $(8000 \mathrm{mR} / \mathrm{H}$ at 1 in.; $2000 \mathrm{mR} / \mathrm{h}$ at $1 \mathrm{ft})$; levels behind lead brick shielding could be much higher.

Installed pipe, valves, and equipment are deteriorated.

Insulation (probably asbestos) is loose.

Many lights nonfunctional.

Gamma radiation (300 $\mathrm{mR} / \mathrm{h}$ at 1 in.) from overhead tank.

Empty.

At one time, housed storage tanks (fission product solutions); tanks and piping removed.

Inactive. Contains storage tank (S-122) and piping. At one time, used to store fission product solutions.

Fixed contamination on cell face area; lead installed to cover nontransferable contamination and provide additional shielding.

Most of dose rate is radiation from manipulator through tubes and hot spots covered with lead. 
Table A.13 (continued)

Operating and

Service Areas (continued)

First level north

Chiller room and air lock: air lock floor contaminated $(300 \mathrm{mR} / \mathrm{h}$ on contact) from past pipe leak; covered by lead sheet; chiller room floor contaminated; nontransferable.

High bay area

Radiation sources are penetrations and fixed contamination on floor; transferable contamination presently low but can change with any operation involving cell.

General

Spots of nontransferable contamination at various places.

\section{Outside}

"Old" filter house

and filter pit area

Filters inside house, 20 to $30 \mathrm{R} / \mathrm{h}$. Top of house is high radiation area (gamma) due to less shielding on top than sides.

Pit penetrations covered with lead shield.

Pump (solid waste)

Transfer pump for old product recovery from waste tank.

No longer used; removal and disposal desirable.

${ }^{\infty} \mathrm{Sr}$-contaminated; base reads $2 \mathrm{R} / \mathrm{h}$ at 1 in.; sits in rusted box; plywood overpack. Box shields most of radiation. 
Table A.14. Building 3517-estimated quantity of contaminated materials (excluding inventory) requiring removal/disposal

\begin{tabular}{|c|c|c|}
\hline Location & Material/status & $\begin{array}{c}\text { Estimated } \\
\text { quantity } \\
\left(\mathrm{ft}^{3}\right)\end{array}$ \\
\hline $\begin{array}{l}\text { Cell 1 } \\
\text { Cell } 2 \\
\text { Cell } 3 \\
\text { Cell } 4 \\
\text { Cell } 5 \\
\text { Cell } 6 \\
\text { Cell } 7 \\
\text { Cell } 8 \\
\text { Cell 9 } \\
\text { Cell 10E } \\
\text { Cell 10W } \\
\text { Cell 11E } \\
\text { Cell 11W } \\
\text { Cell 12 } \\
\text { Cell 13 } \\
\text { Cell 14E } \\
\text { Cell 14M } \\
\text { Cell 14W } \\
\text { Cell 15 } \\
\text { Cell 16 } \\
\text { Cell 17 } \\
\text { Cell 18 } \\
\text { Crane bay } \\
\text { area } \\
\text { Outside }\end{array}$ & $\begin{array}{l}\text { One vacuum hot press and other miscellaneous items } \\
\text { Empty } \\
\text { Empty } \\
\text { Processing tanks and equipment } \\
\text { Processing tanks and equipment } \\
\text { Processing tanks and equipment } \\
\text { Processing tanks and equipment } \\
\text { Empty } \\
\text { Armor plate } \\
\text { Empty } \\
\text { Canned waste, tools, and equipment } \\
\text { Empty } \\
\text { Canned waste, tools, and lights } \\
\text { Vacuum hot press, ejection press, equipment } \\
\text { Press RAM, tools, and equipment } \\
\text { Contaminated lead and left manipulator } \\
\text { Contaminated lead (sheet and shot), vacuum pump } \\
\text { Miscellaneous waste } \\
\text { Drum rack } \\
\text { Ladder and bucket } \\
\text { Metal rack and wooden box } \\
\text { Empty } \\
\text { Movable lift and miscellaneous items } \\
\text { Contaminated pump in rusted box with } \\
\text { plywood overpack }\end{array}$ & $\begin{array}{r}-100 \\
- \\
-430 \\
-430 \\
-430 \\
-430 \\
-\overline{-60} \\
- \\
-7 \\
-7 \\
-7 \\
-100 \\
-7 \\
-30 \\
20 \\
-7 \\
27 \\
7 \\
100 \\
- \\
160 \\
100\end{array}$ \\
\hline
\end{tabular}




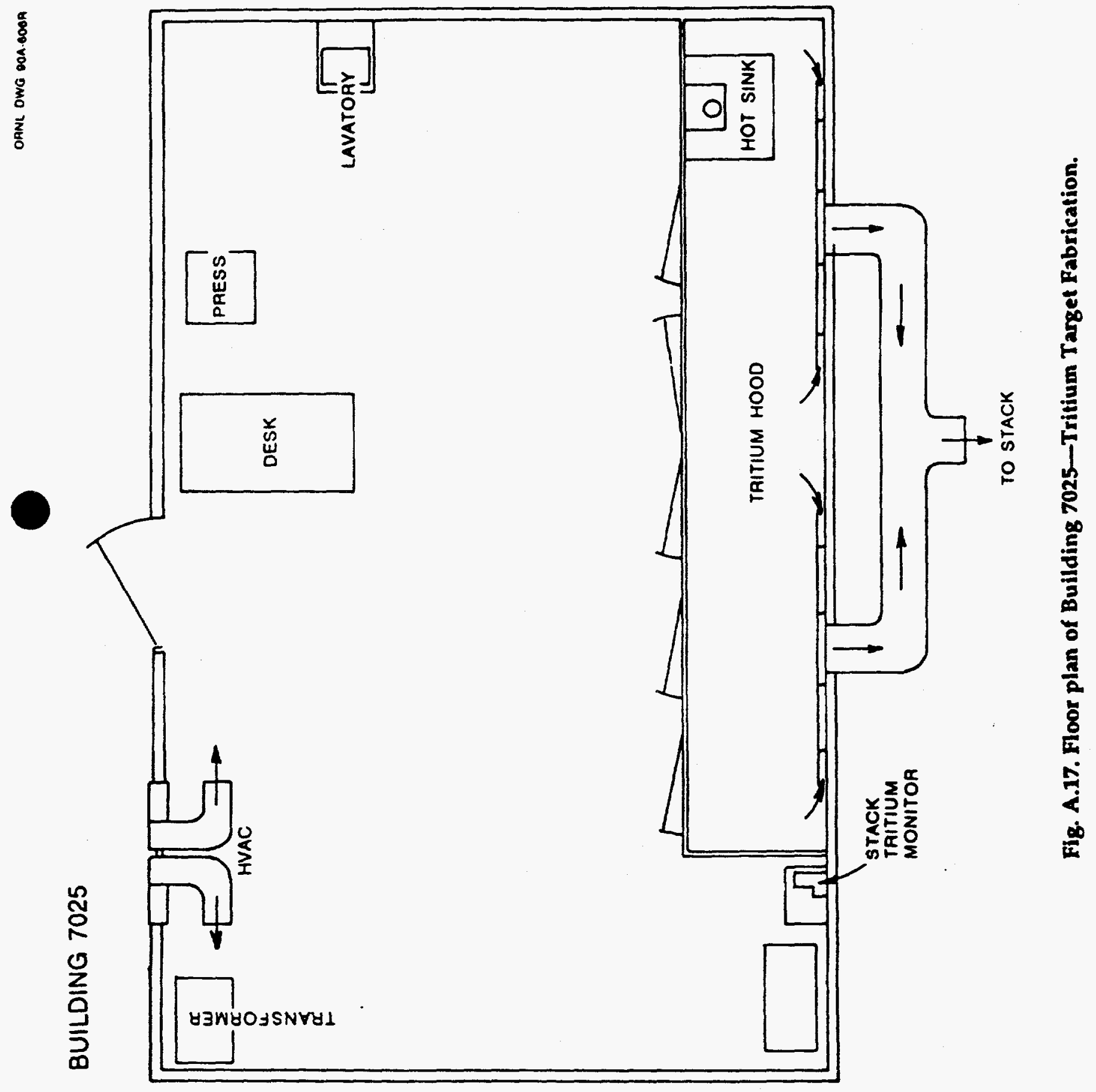

$0 \leftarrow \xi$ 
A forced-air exhaust system that runs continuously is located at the rear of the building. A forced-air input system for heating and cooling is located on the opposite side of the building. The two systems maintain a continuous, high-volume air flow through the building, preventing the buildup of any concentration of tritium gas in the occupied areas of the building in the event of any leakage or spill.

\section{A.2.11.2 History}

Building 7025, which is a Tennessee Valley Authority surplus building, was installed in the late 1960 s to house a tritium target fabrication system. It was programmatically funded into the early 1980 s by the Lawrence Livermore National Laboratory (LLNL) to produce titanium tritide accelerator targets for the Rotating Target Neutron Source facilities at LLNL. Since that time, tritium targets have been prepared for customers on a custom-order basis through the Isotopes Distribution Office. The tritium system has also been used to prepare metallurgical samples for helium embrittlement studies related to fusion energy materials research. Samples were prepared, primarily for ORNL's Metals and Ceramics Division, by diffusing ' $\mathrm{H}$ into metallurgical samples and allowing it to decay to helium. After the desired helium loading was achieved, the remaining ${ }^{3} \mathrm{H}$ was removed from the samples. This process, known as the tritium trick process, was last performed for two groups of researchers in Germany and California during the fall of 1989.

As a result of overcrowding in Building 3550, the $\mathrm{ThO}_{2} / \mathrm{NO}_{2}$ evaporator was moved to Building 7025 in the late 1970 s and has been used to prepare hundreds of oxide thin films for a variety of customers around the world.

\section{A.2.11.3 General Status}

All tritium processing activities in this facility were halted in October 1989. All bulk tritium and the uranium storage traps have been removed from Building 7025 . The primary portions of the tritium processing manifold are highly contaminated with tritium.

Operation of the $\mathrm{ThO}_{2} / \mathrm{NO}_{2}$ high-vacuum system was continued until January 1990, when it was halted because of funding problems. The $\mathrm{ThO}_{2} / \mathrm{UO}_{2}$ system is in the process of being disassembled and disposed of as waste. $A$ highvacuum titanium evaporator system has been relocated to Building 9204-3.

The general status of Building 7025 is summarized in Table A.15.

\section{A.2.12 BUILDING 9204-3-ACTINIDE AREA}

\section{A.2.12.1 Description}

A small area, designated as the Actinide Area, within Building 9204-3 at the Y-12 site is included in the deactivation project. Building $9204-3$ contains $114,600 \mathrm{ft}^{2}$ in a basement, first and second floors, and a mezzanine. Most of the building is devoted to isotopes production. The area of interest for the deactivation project is located at 
Table A.15. Building 7025-general status of facility

Facility/area

Comments

\section{Building}

Type

Roof and exterior walls

Building ventilation

Liquid waste systems

Monitoring

Hoods

Tritium hood

Alpha hood

Stored Materials
Prefabricated metal.

Fair condition.

Forced-air exhaust system that runs continuously; local stack at rear of building; forced air input system for heating and cooling is located on opposite side of building and operates continuously as a backup for ventilation (at reduced flow) in the event the exhaust fan should fail.

HEPA filter on alpha hood. No filter on tritium hood because no solid radioactive particulates that could be filtered were handled (i.e., only gases).

No liquid wastes generated by process. Lavatory sink bottled for disposal. Sanitary facilities at the $\mathbf{7 0 0 0}$ Area.

Hot drain in east end of tritium hood. Drains to underground tank (inactive) outside. The tank has been emptied.

Stack monitor for tritium operated by ORNL Environmental Monitoring Group. Smoke detectors monitored by ORNL fire department. No sprinkler system.

The equipment and hood are highly contaminated with tritium. There will be a residual release of tritium, as the tritium imbedded in the equipment slowly diffuses from the metal.

Contaminated with uranium and thorium; HEPA filter on hood.

None 
the east end of the second floor of the building. It consists of (1) the calutron operations area where the electromagnetic separation of actinide isotopes was performed and (2) components wash and service area where the actinide isotopes were removed from the calutron receivers and the calutron receivers were prepared for use (Fig. A.18). The calutron area is approximately $2700 \mathrm{ft}^{2}$, and the wash area is about $1800 \mathrm{ft}^{2}$. Most of Building $9204-3$ is used for stable isotopes work and is planned to remain operational.

The actinide processing facility is in a contained area within the building. The components wash area operates at -0.15 in. w.g. and the other areas at -0.1 in. w.g. relative to the surrounding building areas. Glove boxes and enclosures have HEPA filters on the air inlet and prefilters and HEPA filters on the exhaust. Air is then routed through a common duct system to a second stage of HEPA filters. Exhaust fans are supplied with emergency power. Entries are provided with air locks. In addition to the two rooms on the deactivation list, the containment area also houses the actinide chemical processing area (a series of glove-box operations), change room, and locker room.

The actinide processing facilities have been on standby since 1980. The equipment and enclosures were cleaned and readily dispersable material removed when the facilities were placed in standby. The equipment has been maintained and, in general, is considered to be in good condition.

\section{A.2.12.2 History}

The electromagnetic separation facilities were originally constructed to separate uranium isotopes and recover uranium enriched in ${ }^{233} \mathrm{U}$. With the successful operation of the gaseous diffusion process, the calutrons were phased out as a production operation for enriching uranium. About 1962, the area of Building 9204-3, now known as the actinide processing area, was modified to separate actinide isotopes for research purposes. This was new construction, except for the calutron itself. The calutron was modified so that only a portion of the machine was used to accommodate smaller samples. The actinide facility operated continuously until the mid-1970s, was in standby for a short time, was operated again in the late 1970 s to isolate ${ }^{20} \mathrm{Pu}$, and then placed in standby again in 1980 . The facility has been maintained in such a condition that it could be restarted. Two glove boxes in the chemical processing area are still being used for weighing and packaging actinides. This part of the facility is planned to remain operational.

\section{A.2.12.3 General Status}

The actinide operations area and components wash and service area in Building 9204-3 were placed in standby in 1980. The general status of the facility is summarized in Table A.16. 


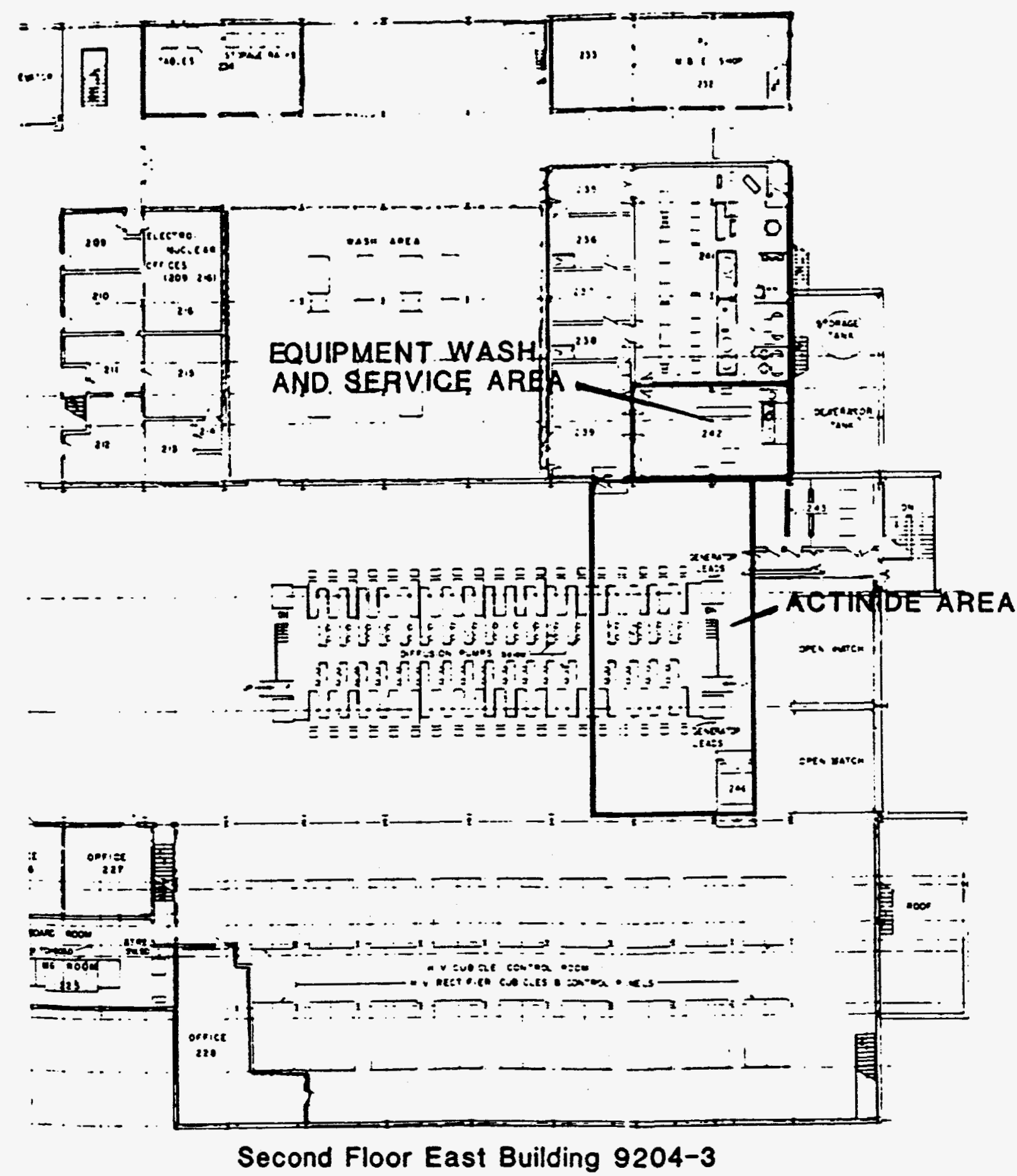

Fig. A.18. Floor plan of Actinide Area in Building 9204-3, second floor east, showing the calutron operations and the equipment wash and service areas. 


\section{A.86}

Table A.16. Actinide area of Building 9204-3-general status of facility

Facility/area

Comments

Facility

General condition

Small area within a building; most of building is planned to remain operational.

Good condition; contaminated, but relatively clean (i.e., relatively free of dispersable materials).

Facility containment and ventilation

Rooms are inside a contained area within a building; air locks.

Components wash area maintained at -0.15 in. w.g. and other areas at -0.1 in. w.g. relative to the surrounding building areas.

Liquid waste systems

No liquid waste is expected during shutdown.

Actinide facility, when operated, was equipped with a dedicated liquid waste evaporator; condensate was monitored for radioactivity; if acceptable for discharge, it was routed to the waste tank that serves the building. No hot or process drains except to recovery system. No floor drains. Evaporator in standby.

Building in general (current operations): liquid waste routed to waste tank; neutralized; transferred to Y-12 Plant tank farm.

Inventory

None. 
Appendix B

PROJECT SCHEDULES 
-

-

- 


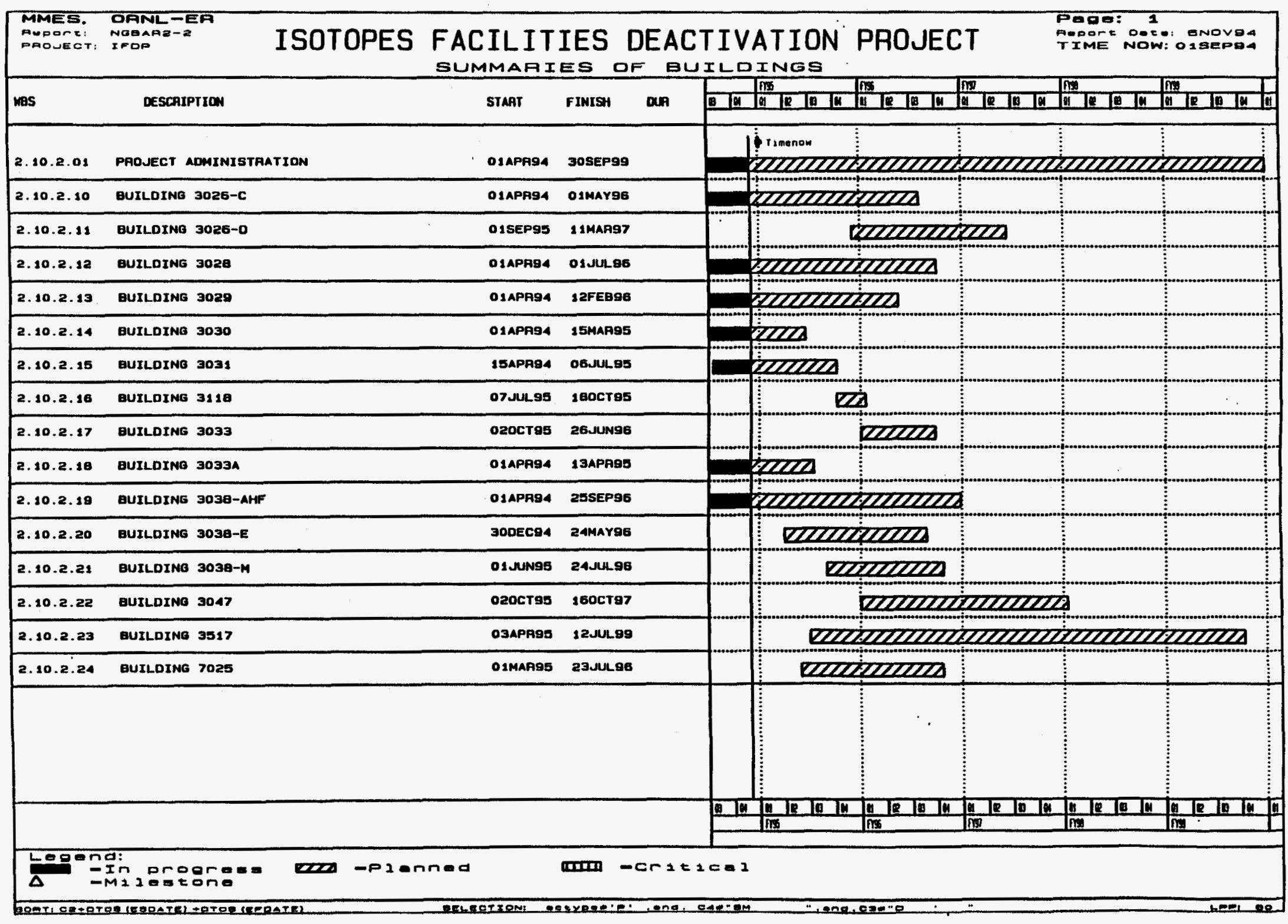




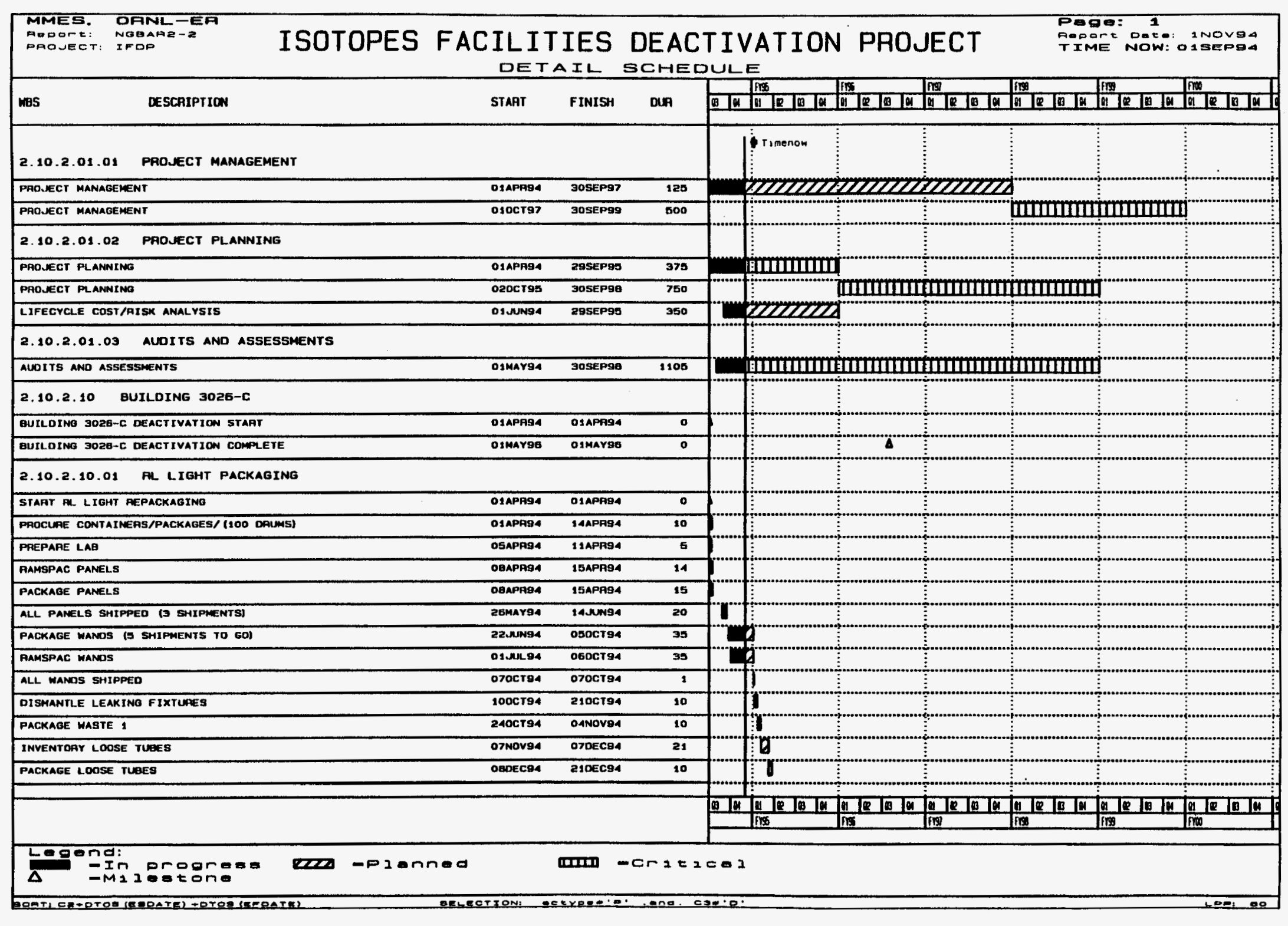




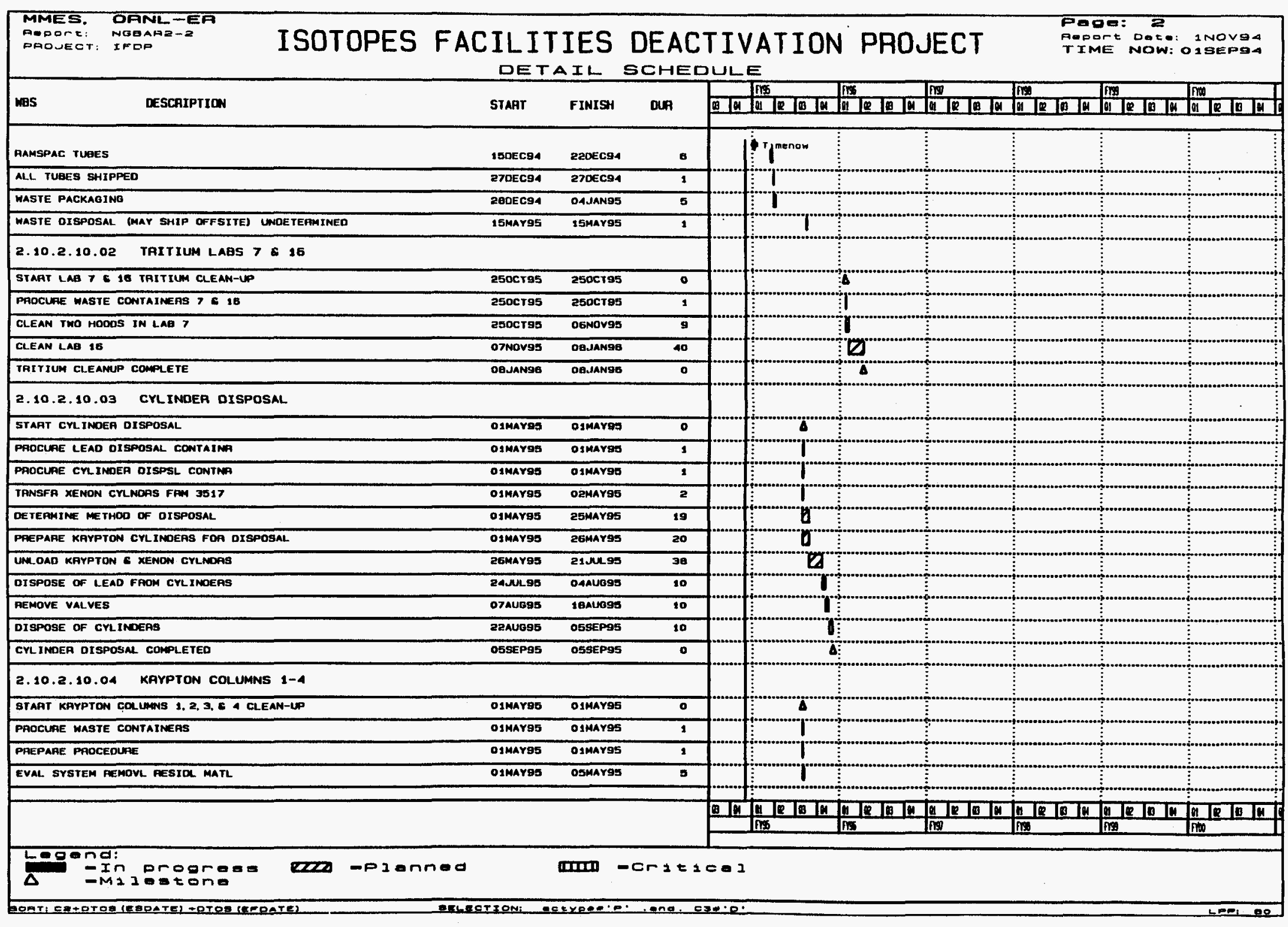




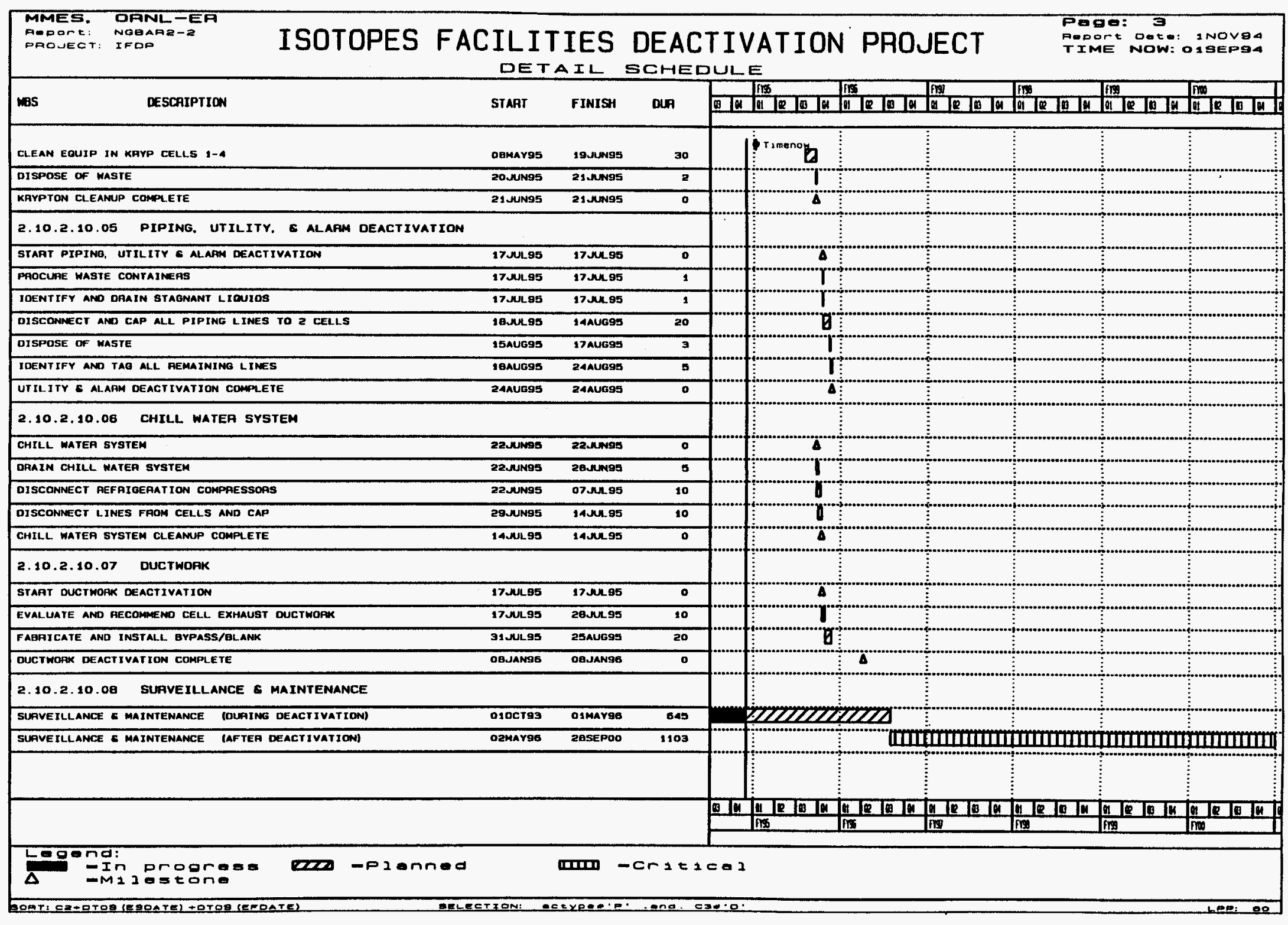




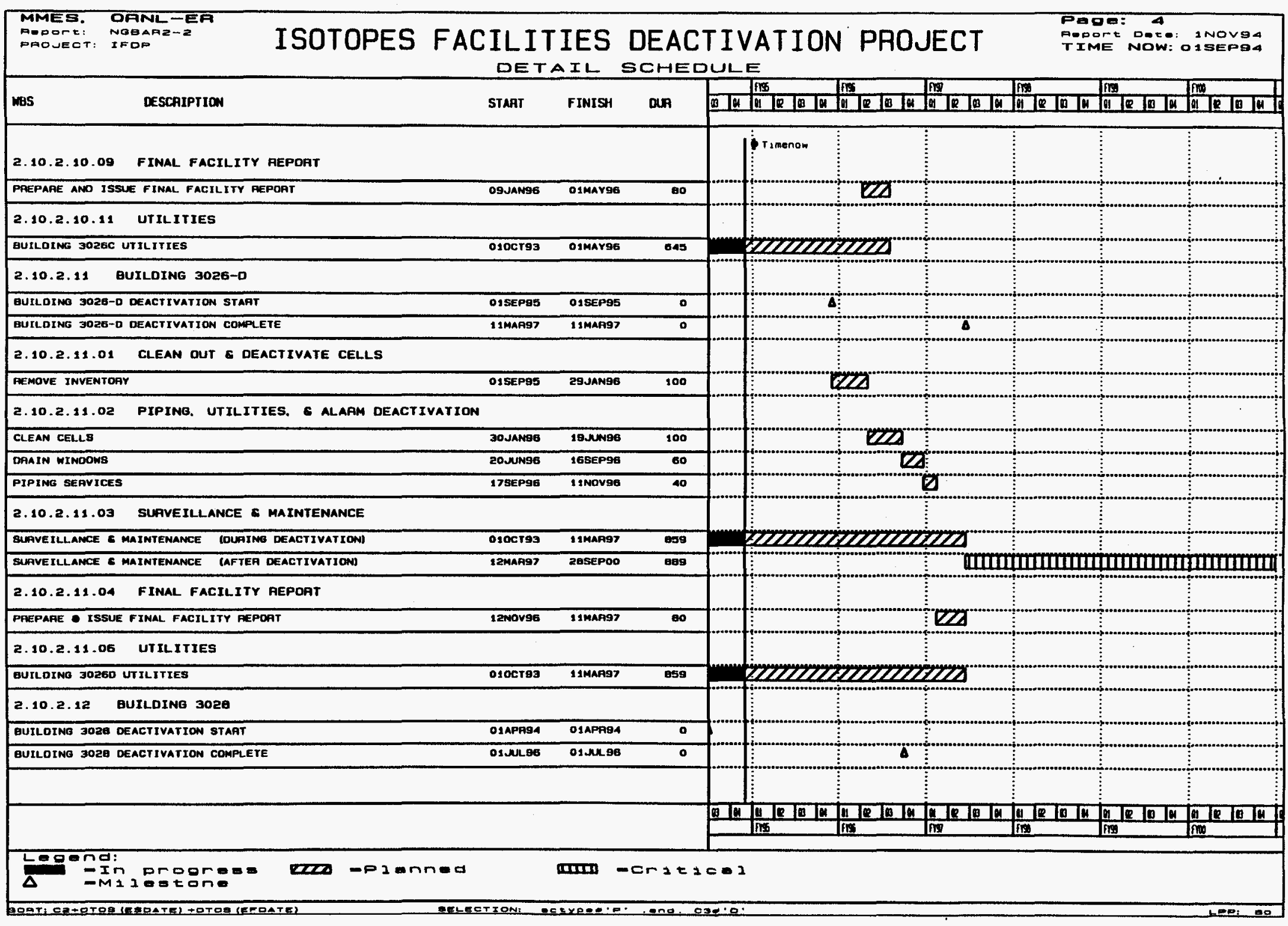




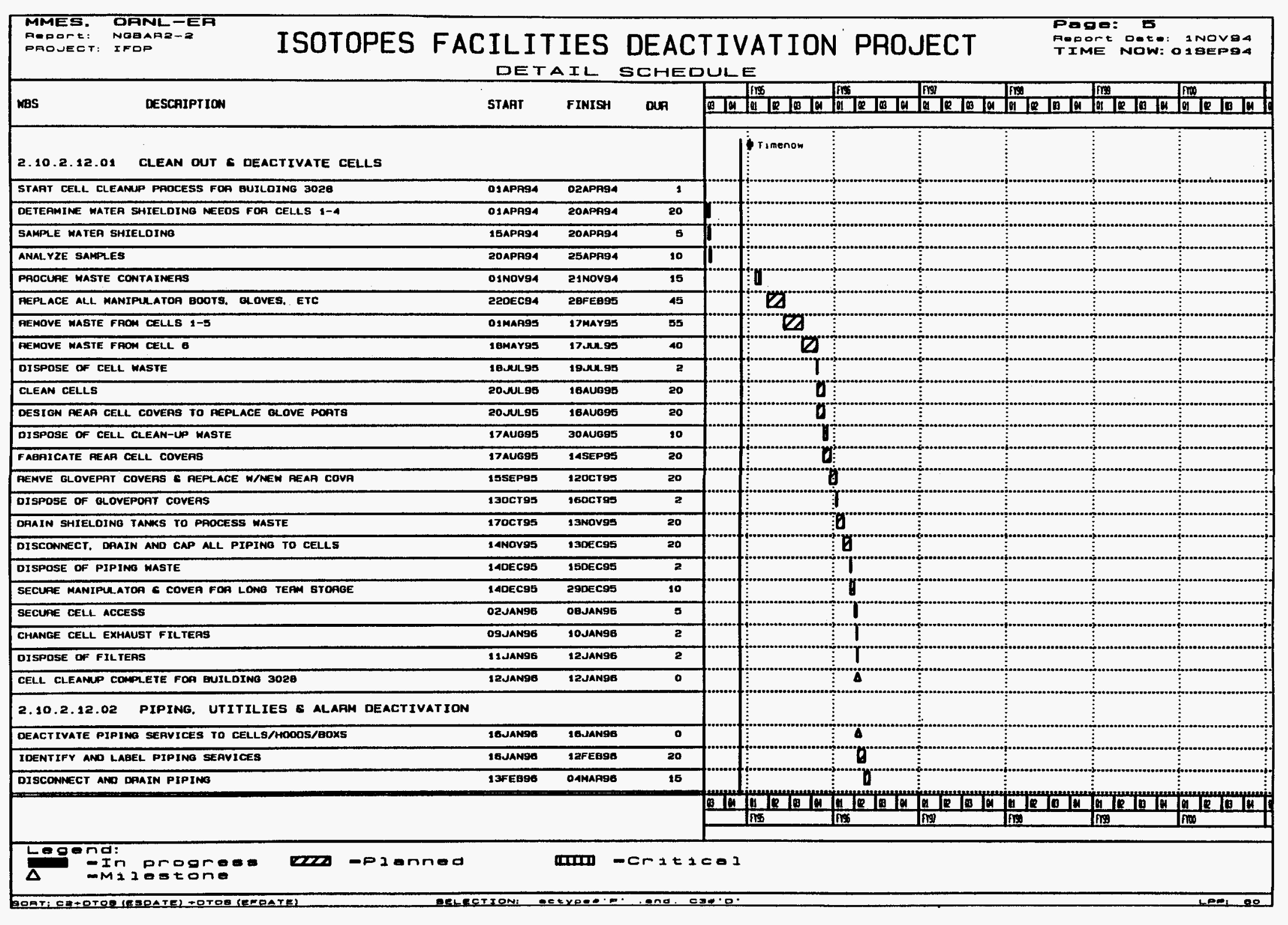




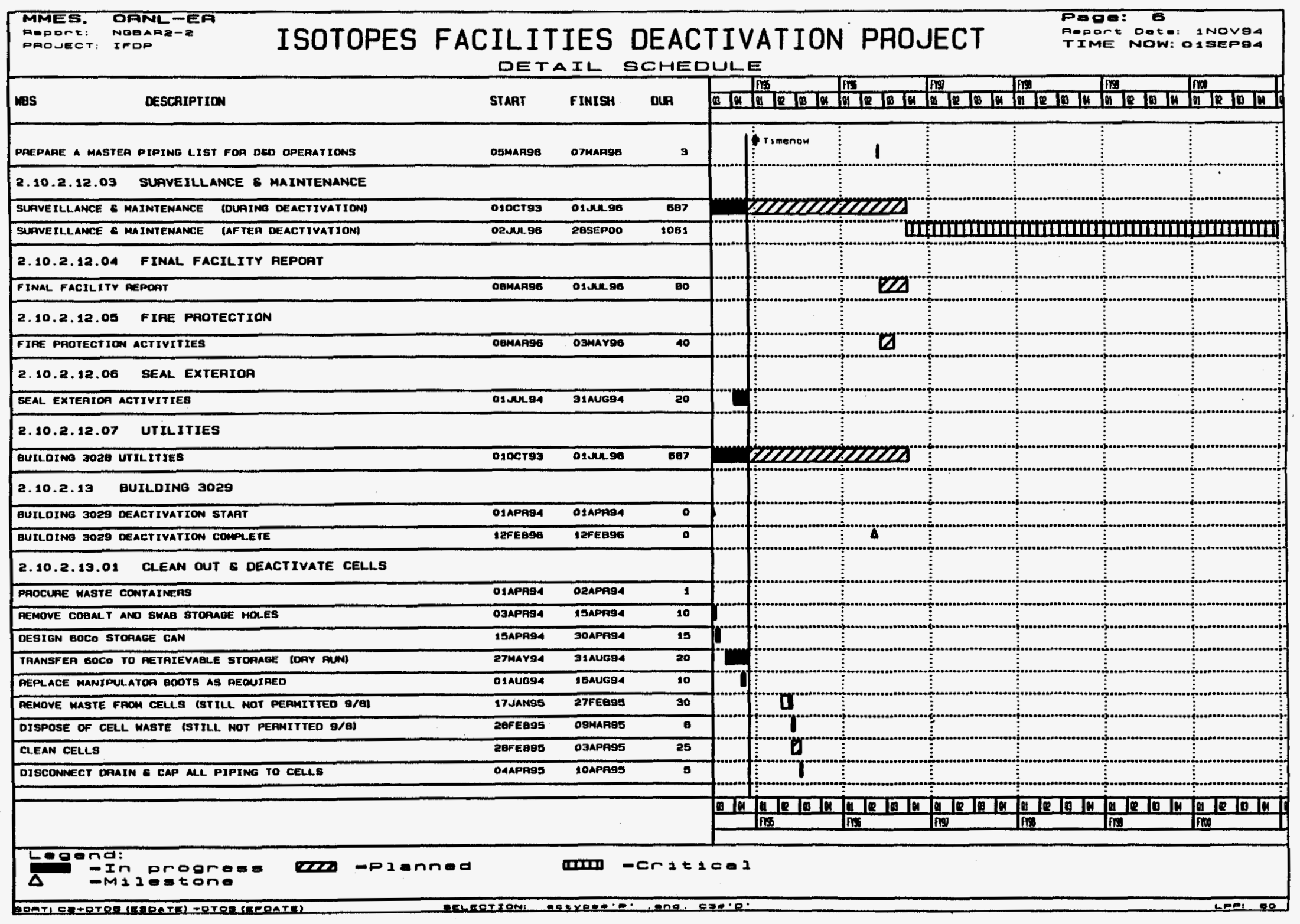




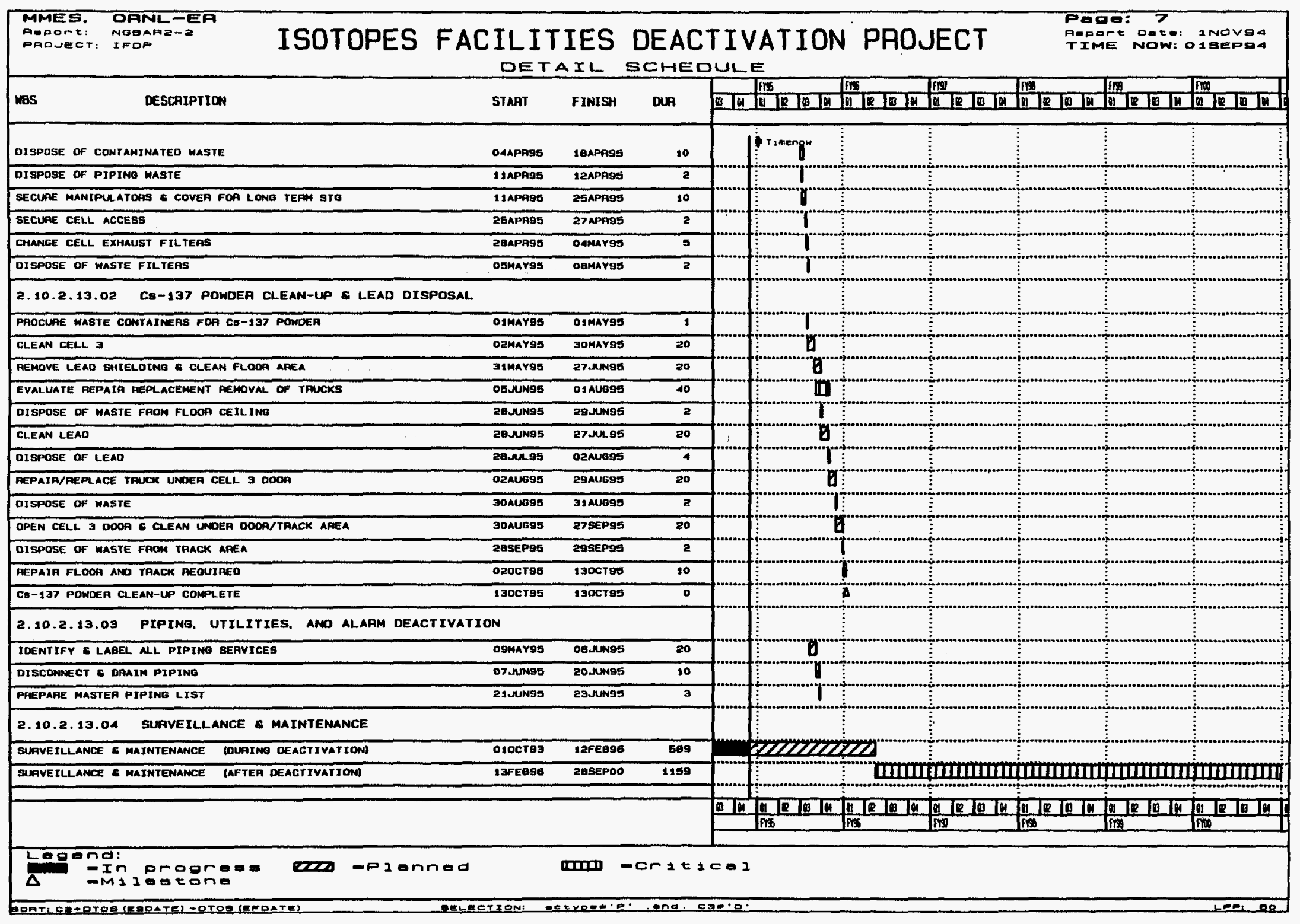




\begin{tabular}{|c|c|c|c|c|c|c|c|c|}
\hline \multicolumn{2}{|l|}{ 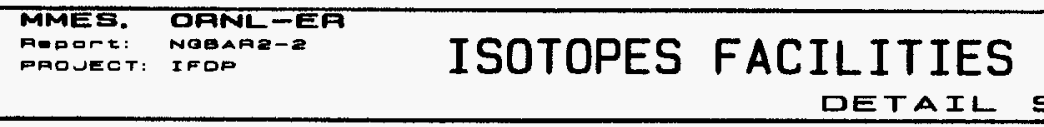 } & \multicolumn{4}{|c|}{$\begin{array}{l}\text { DEACTIVATION PROJECT } \\
\text { SCHEDULE }\end{array}$} & \multicolumn{3}{|c|}{ 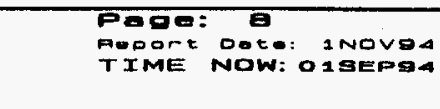 } \\
\hline WES DESCAIPIION & FINISH & DUA & 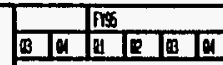 & 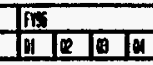 & 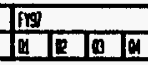 & 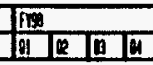 & 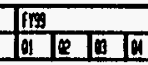 & \\
\hline 2.10.2.13.05 FINAL FACILITY REPOAT & & & Tamenom & & & & & \\
\hline FINAL FACILITY REPOAT & 12FEB96 & 80 & & Z2Z & & & & \\
\hline 2.10.2.13.08 FIAE PROTECTION & & & & & & & & \\
\hline FIAE PAOTECTION ACTIVITIES & 120DEC95 & $\$ 0$ & & 8 & & & & \\
\hline 2.10.2.13.07 SEAL EXTEATOA & & & & & & & & \\
\hline SEAL EXTEAIOA ACTIVITIES & 15A4Ua94 & 20 & $1:$ & & & & & \\
\hline 2.10.2.13.08 UTILITIES & & & & & & & & \\
\hline BURLOING 3029 UTILITIES & 12FEQ98 & 5e9 & 2228272 & $22 \pi$ & & & & \\
\hline 2.10 .2 .14 BUILOING 3030 & & & & & & & & \\
\hline BUTLOTMG 3030 DEAGTIVATION STAAT & O1APA94 & $\overline{0}$ & 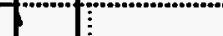 & & & & & \\
\hline 2.10.2.11.01 CLEAN OUT C DEACTIVATE CELLS & & & & & & & & \\
\hline PROCUPE HASTE CONTAINEAS & OEAPA94 & 1 & 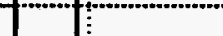 & & & & & \\
\hline HEMOVE MASTE MATEAIAL CELL & $1300 \mathrm{rg4}$ & 30 & 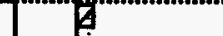 & & & & & \\
\hline CMANGE CELL FILTEAS & 19SEP94 & 1 & $t$ & & & & & : \\
\hline DISPOSE OF CELL MASTE & $170 \mathrm{CT} 94$ & 2 & 1 & & & & & \\
\hline CLEEAN CELL & 15NOVG4 & 21 & U & & & & & \\
\hline PEPLACE CELL DOOP OASKET & O10EC94 & 10 & $0^{\circ}$ & & & & & : \\
\hline DISCONMECT \& CAP ALL PIPING LIMES TO CELL & 150EC94 & 20 & $" \theta$ & & & & & \\
\hline DISPOSE OF PIPINO MASTE & 19DEC94 & 2 & “T & & & & & $\because$ \\
\hline SECURE CELL ACCESS POATS E CELL PENETRATIONS & 15FEg95 & 10 & Ea & & & & & \\
\hline 2.10.2.14.02 PIPING, UTILITIES ANO ALAPM DEACTIVATION & & & & & & & & \\
\hline CLEAN HOODS & $170 \mathrm{CTSA}$ & 21 & {$[1]^{\circ}$} & & & & & : \\
\hline DISPOSE OF CONTAMINATEO MASTE & $190 \mathrm{cr94}$ & $\mathbf{a}$ & [" & & 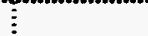 & & 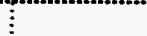 & 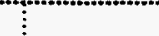 \\
\hline IO ALL PIPES, VALVES, ETC. & $2400 \mathrm{T94}$ & 5 & I & & & & & \\
\hline & & & 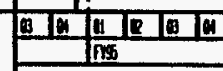 & 要品 & 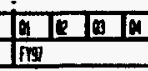 & $f \frac{1}{n}$ & in & $\int_{\text {nom }}$ \\
\hline
\end{tabular}




\begin{tabular}{|c|c|c|c|c|c|c|}
\hline 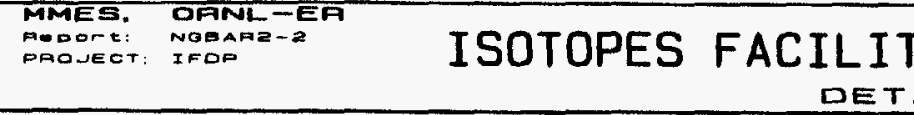 & IES & $\begin{array}{l}\text { DEAC } \\
\text { SCHE }\end{array}$ & $\begin{array}{l}\text { TIVATION } \\
\text { DULE }\end{array}$ & N PAOJECT & $\begin{array}{l}\text { PEge: 9 } \\
\text { Ropore Date: } \\
\text { TIME NOW: }\end{array}$ & $\begin{array}{l}\text { INOVSA } \\
\text { OISEPGA }\end{array}$ \\
\hline DESCAIPTION & FINISH & DUP & 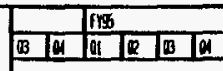 & 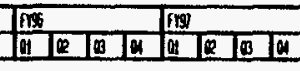 & 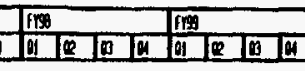 & \\
\hline 2.10.2.14.03 SUPVE ILLANCE \& MAINIENANCE & & & Timenow & & & \\
\hline SUPVE ILLANCE E MAINTENANCE T(DURING DEACTIVATION) & 15MAA9S & 362 & YZZ" & & & \\
\hline SURVE ILLANCE \& MA INTENANCE (AFTER OEACT IVAYION) & 2QSEPOO & 1386 & 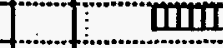 & 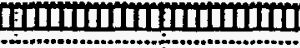 & 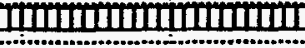 & mimmimim \\
\hline 2.10.2.14.04 FINAL FACILITY REPOHT & & & & & & \\
\hline FINAL FACILITY REPOAT & 15MAA95 & 20 & 是 & & & \\
\hline 2.10.2.14.05 SEAL EXTEAIOA & & & & & & \\
\hline SEAL EXTEAIOA ACTIVITIES & 16NOVIA & 20 & U & & & \\
\hline 2.10.2.14.06 UTILITIES & & & & & & \\
\hline BUILOING 3030 UTILITIES & 15 MAA95 & 362 & 223 & & & \\
\hline 2.10.2.15 BUILDING 3031 & & & & & & \\
\hline BUILOING 3O3: DEACTIVATION STAAT & 15APA94 & a & 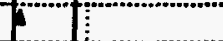 & & & \\
\hline BUTLOTNG 3031 DEACTIVATION COMPLETE & 06 vin.95 & $\stackrel{0}{\circ}$ & 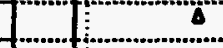 & & & \\
\hline 2.10.2.15.01 CLEAN-UP S DEACTIVATE CELLS & & & & & & \\
\hline CLEAN HOOOS & 29N0Vg4 & 30 & in & & & \\
\hline CLEAN OUT CELLS & SOJANG5 & 40 & E & & & \\
\hline SECUAE CELL ACCESS POATS \& MISC, CELL PENETAAATIONS & 27FEB95 & 20 & "bo & & & \\
\hline FEPLACE CELL DOOA GASKEY & 23MARGS & 10 & 6 & & & \\
\hline REMOVE MASTE MATEATAL FAOM CELL & 27MAA95 & 10 & t.... & & & \\
\hline DISPOSE OF CELL MASTE & 29MAR95 & 2 & (1... & & & \\
\hline CLEAN-UP OF CELL MASTE COMPLETE & 29MAR95 & 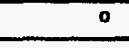 & a...... & & : & \\
\hline 2.10.2.15.02 DEACTIVATE PIPING SEAVICES S ALARM DEACTIVATION & & & & & & \\
\hline ID ALL VALVES, PIPES & O7MAA95 & 5 & & : & :.... & \\
\hline PFOCUPE MASTE CONTAIMERS & DQMAR9S & 1 & & $=$ & & \\
\hline DISCOMMECT C CAP ALL PIPIMG LINES TO CELL & DSAPA9S & 20 & b & & & \\
\hline \multirow[t]{2}{*}{ OISPOSE OF PIPING MABTE } & O7APPQS & 2 & & $\because$ & 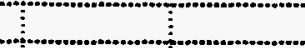 & $\vdots$ \\
\hline & & & 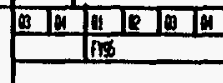 & Inte & 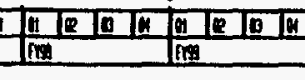 & IfIR \\
\hline 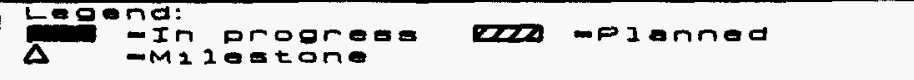 & III) & -crits & $=1$ & & & \\
\hline
\end{tabular}




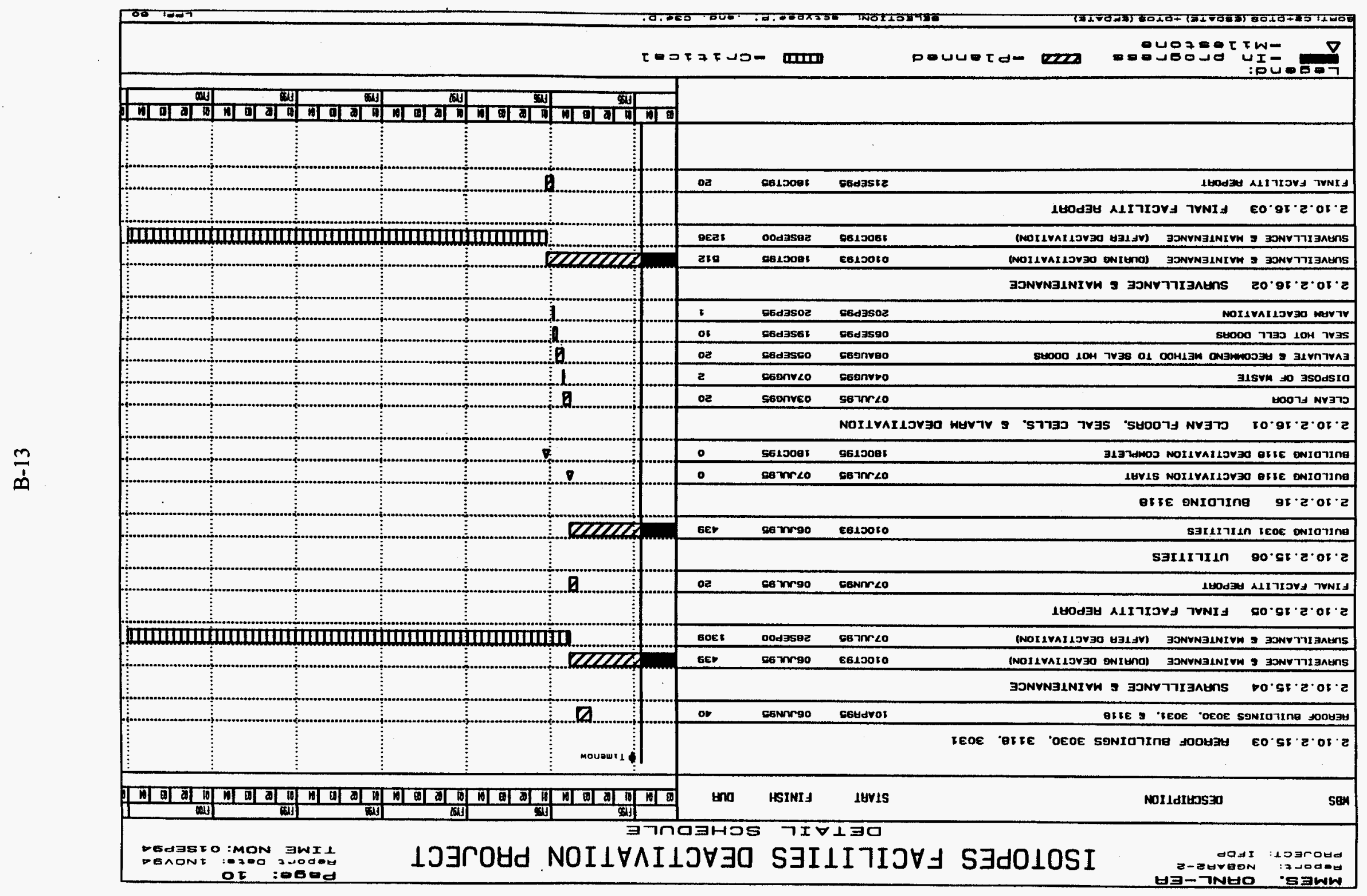




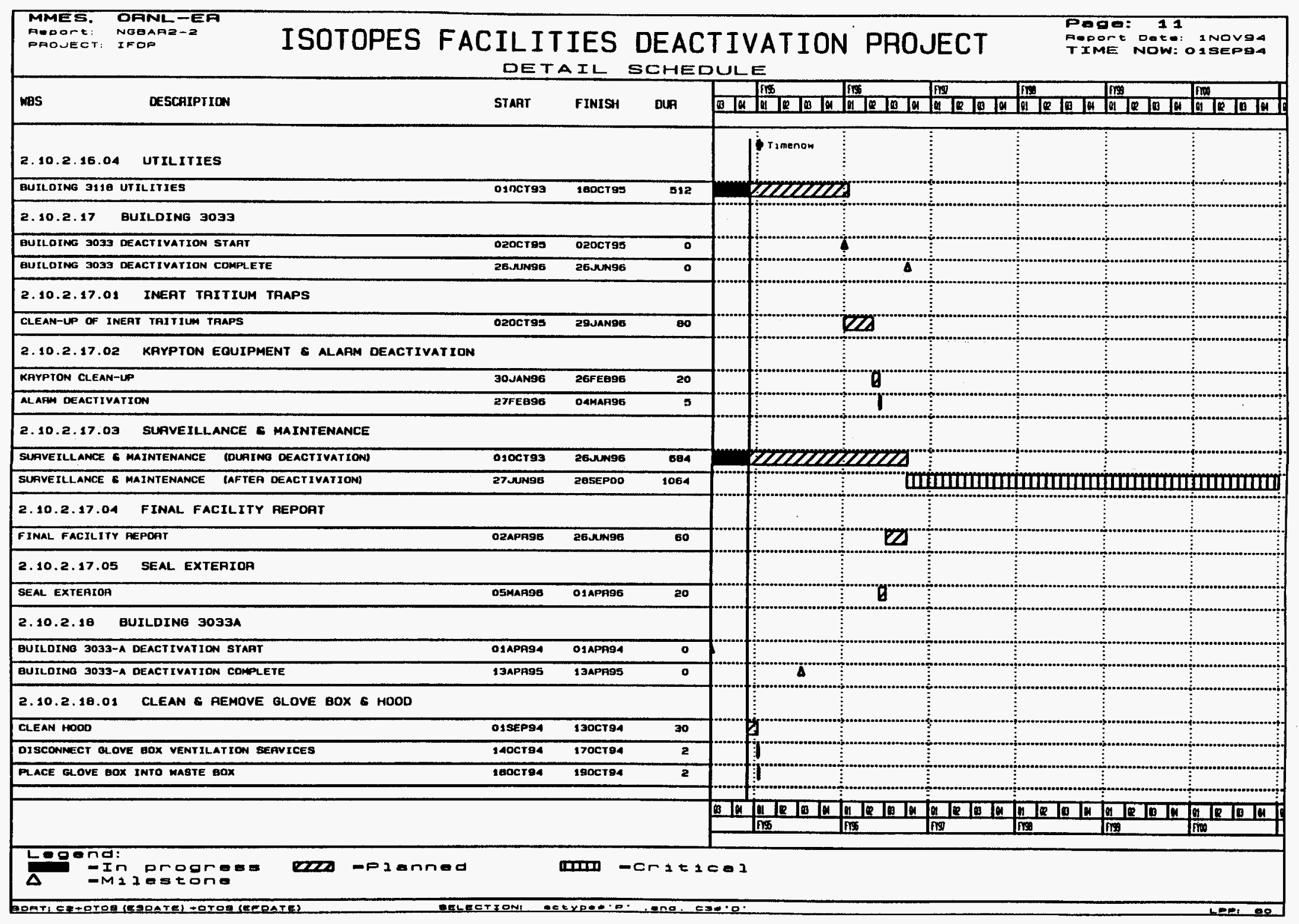




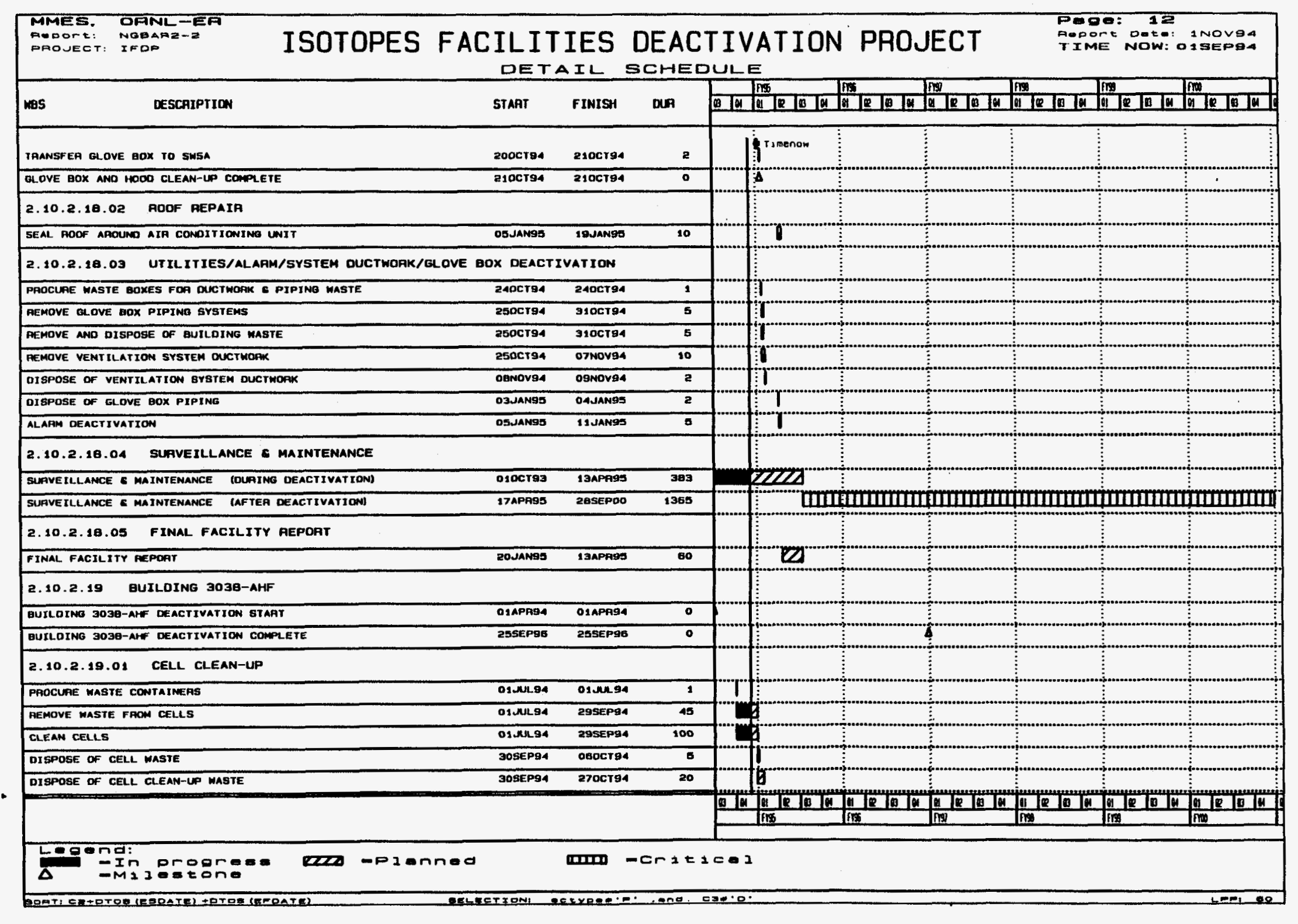




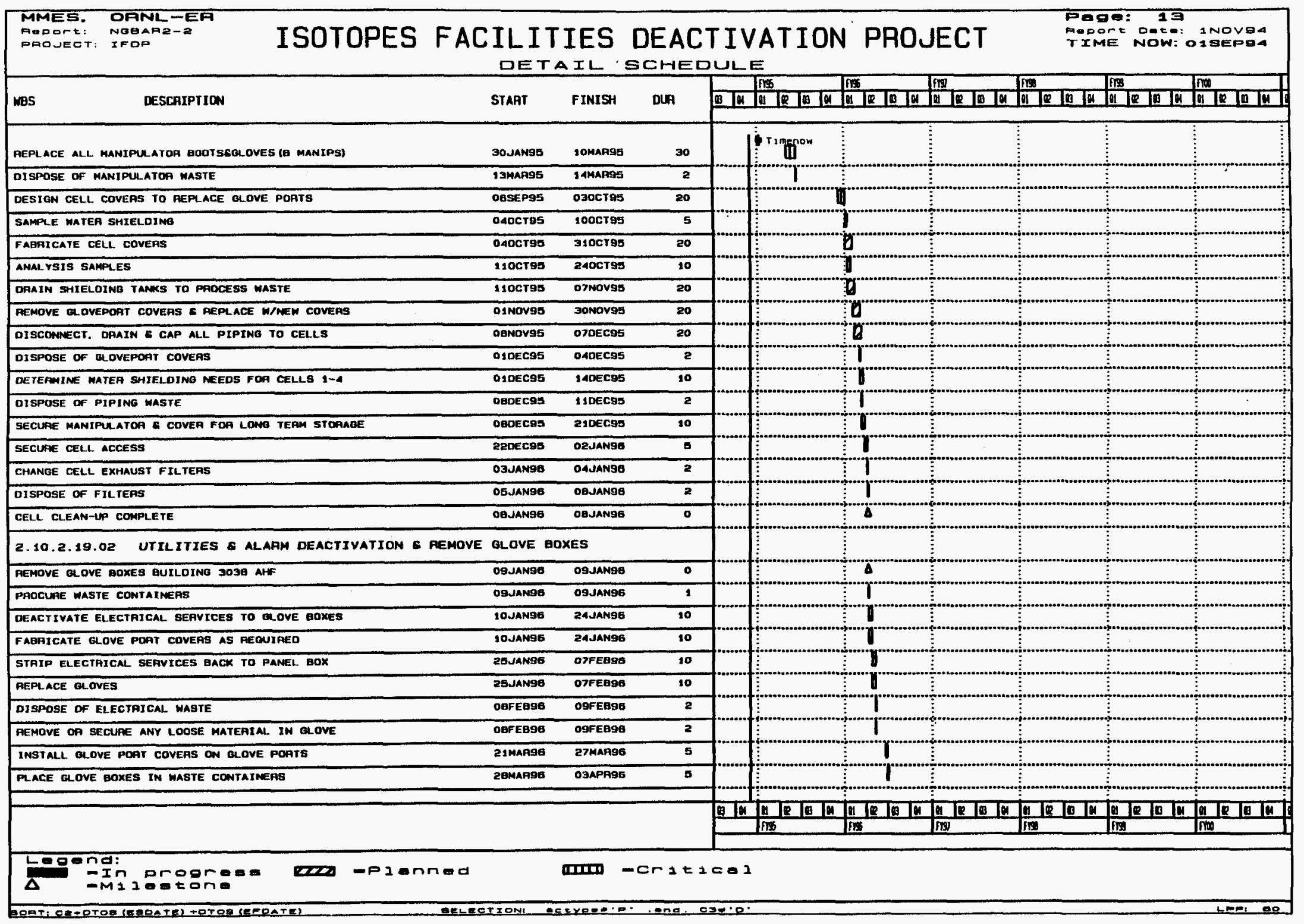




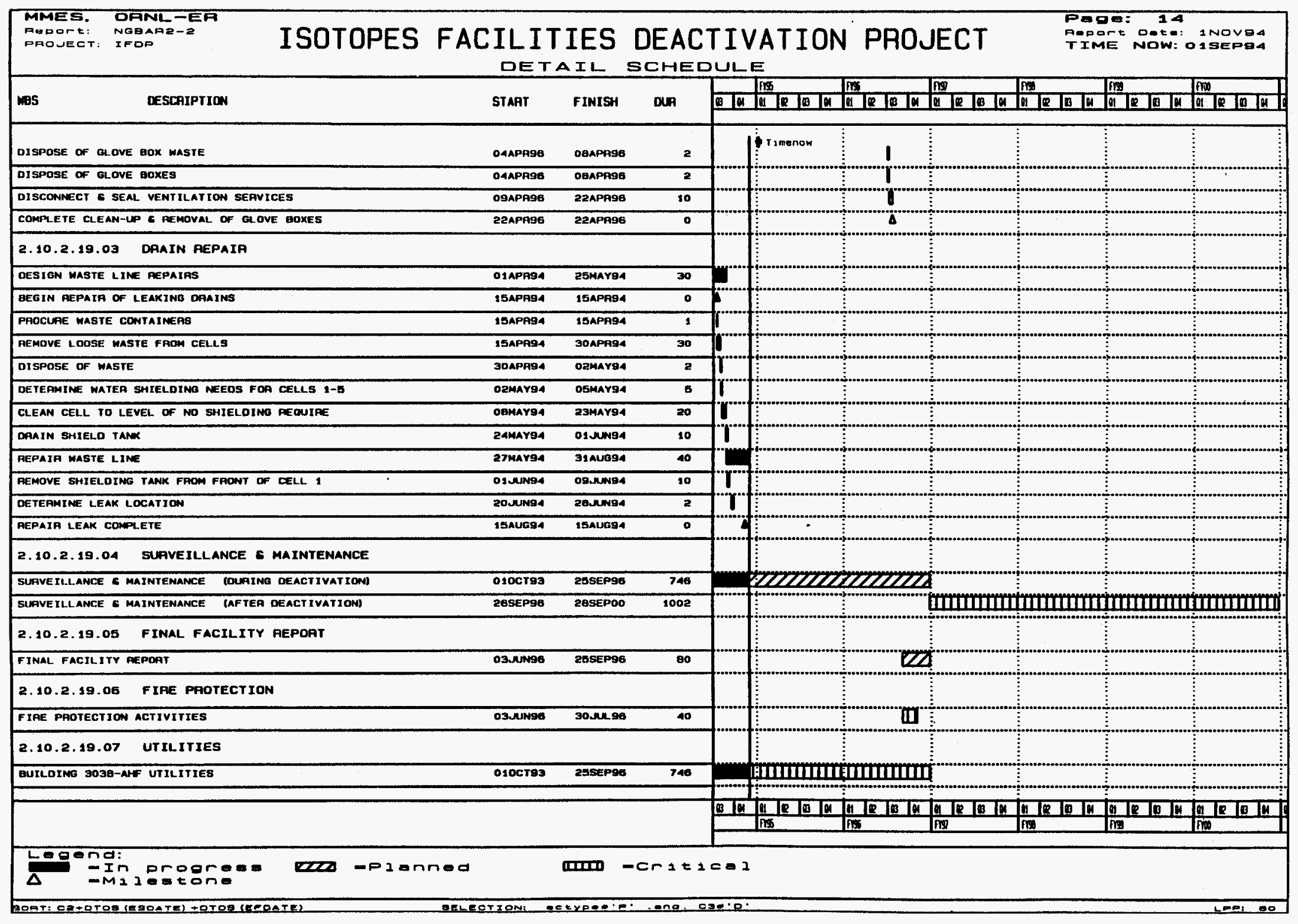




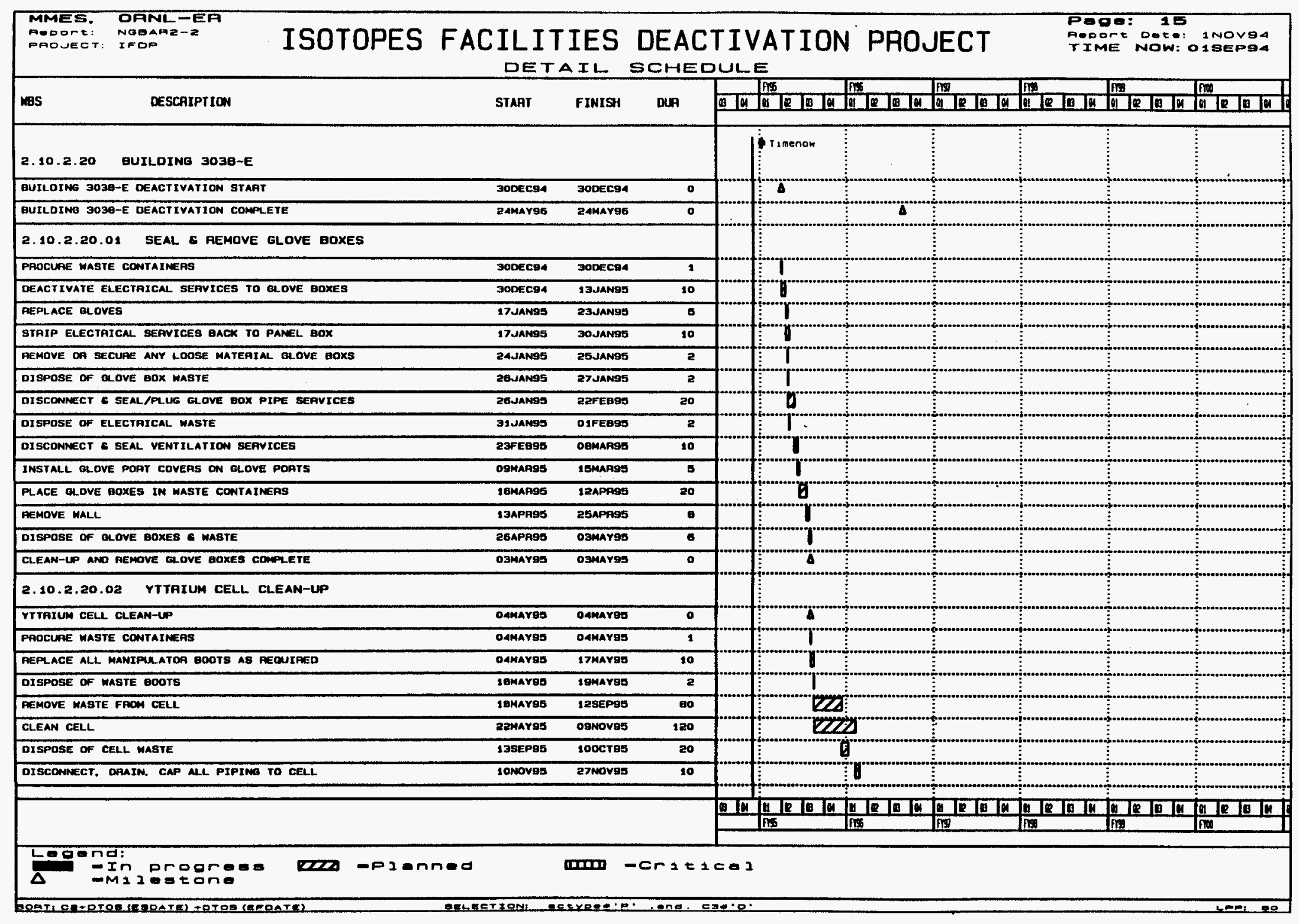




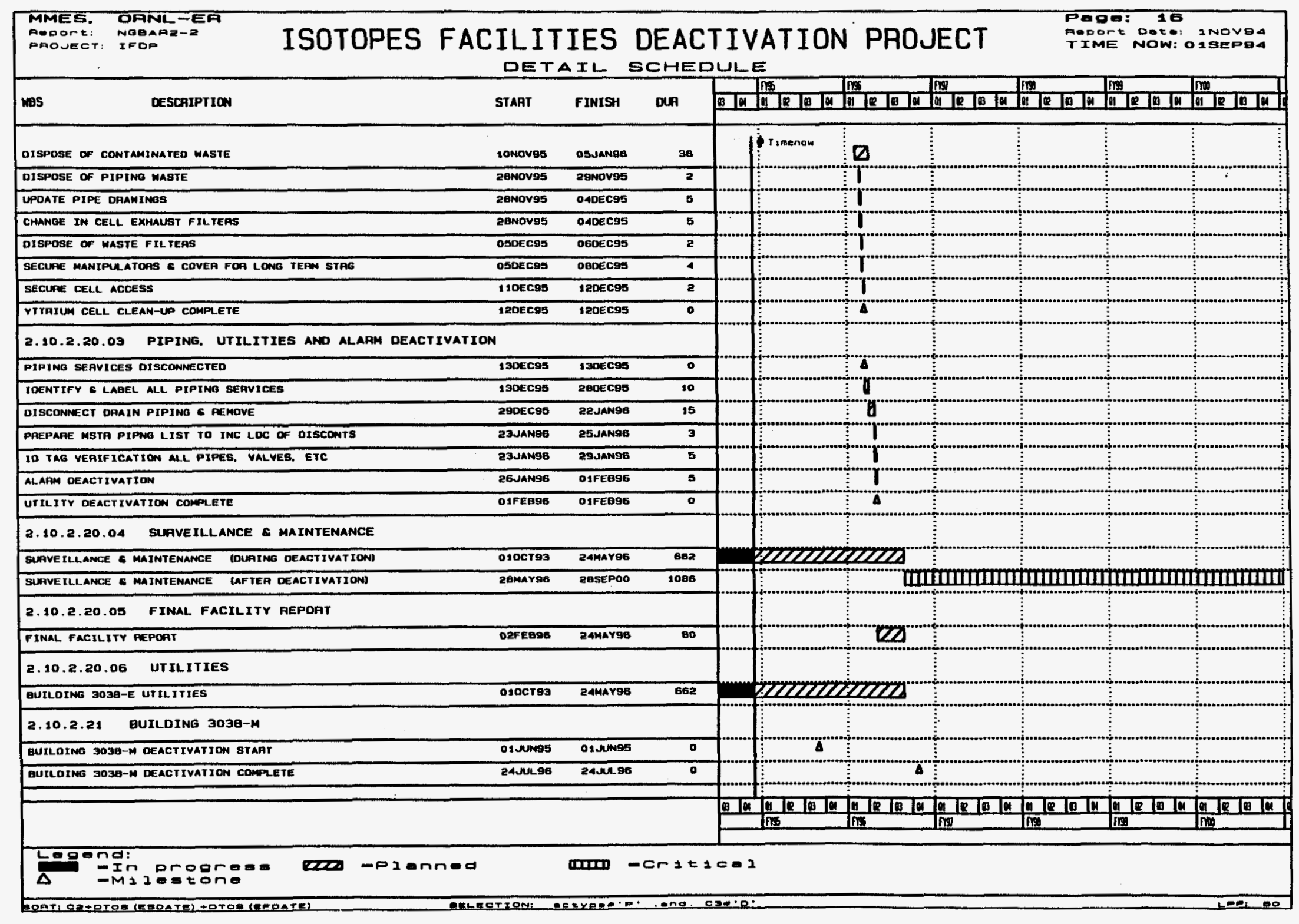




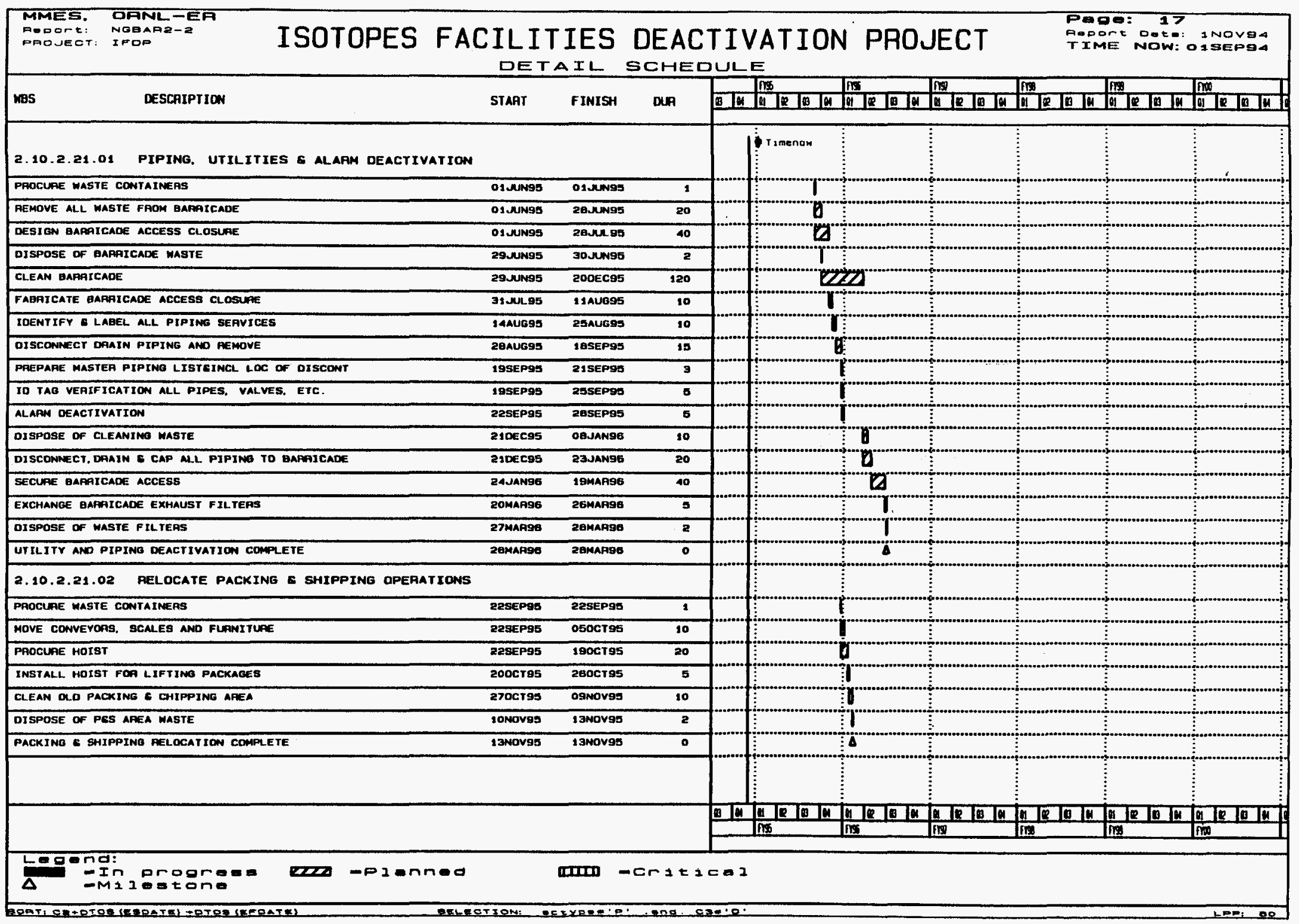




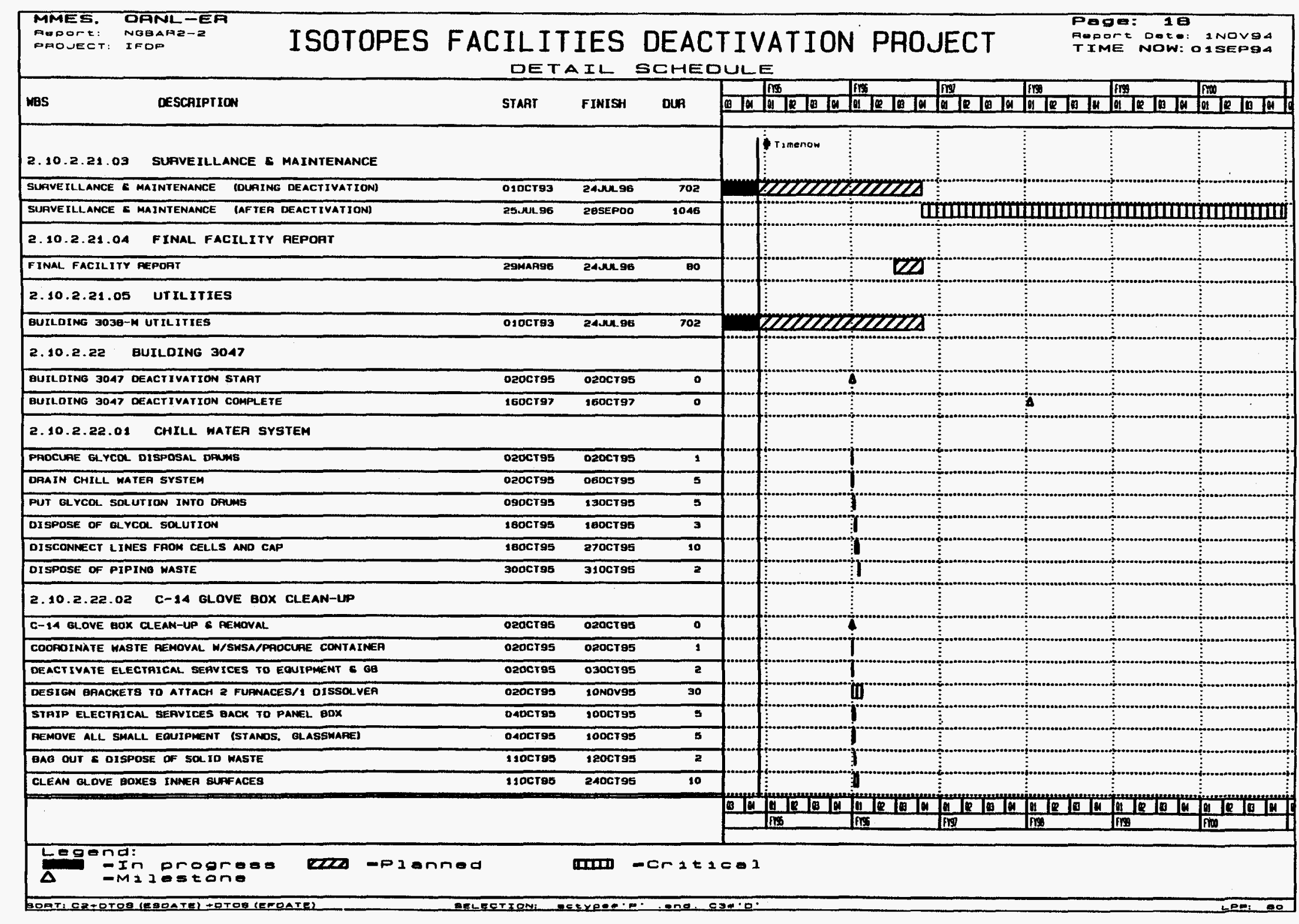




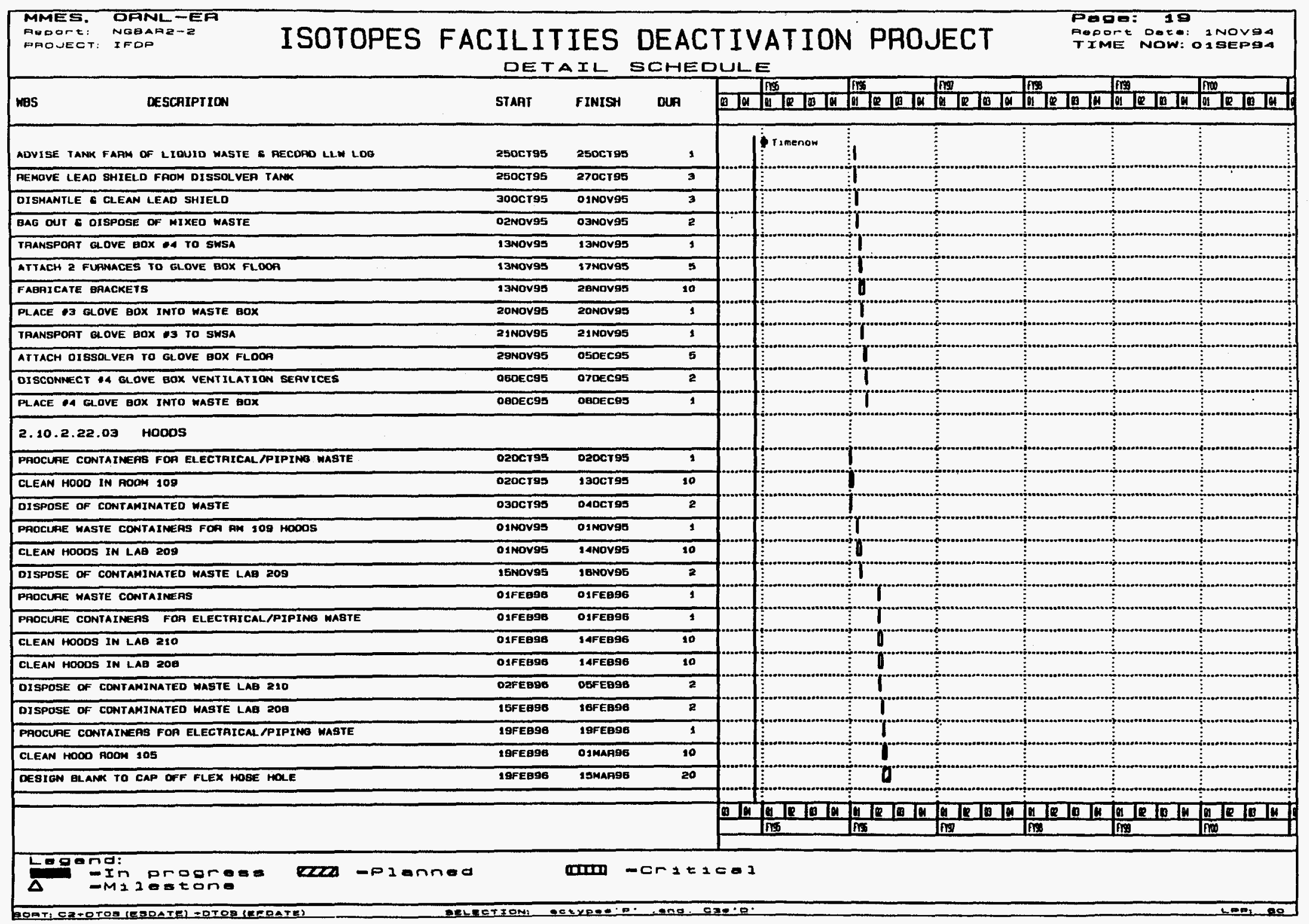




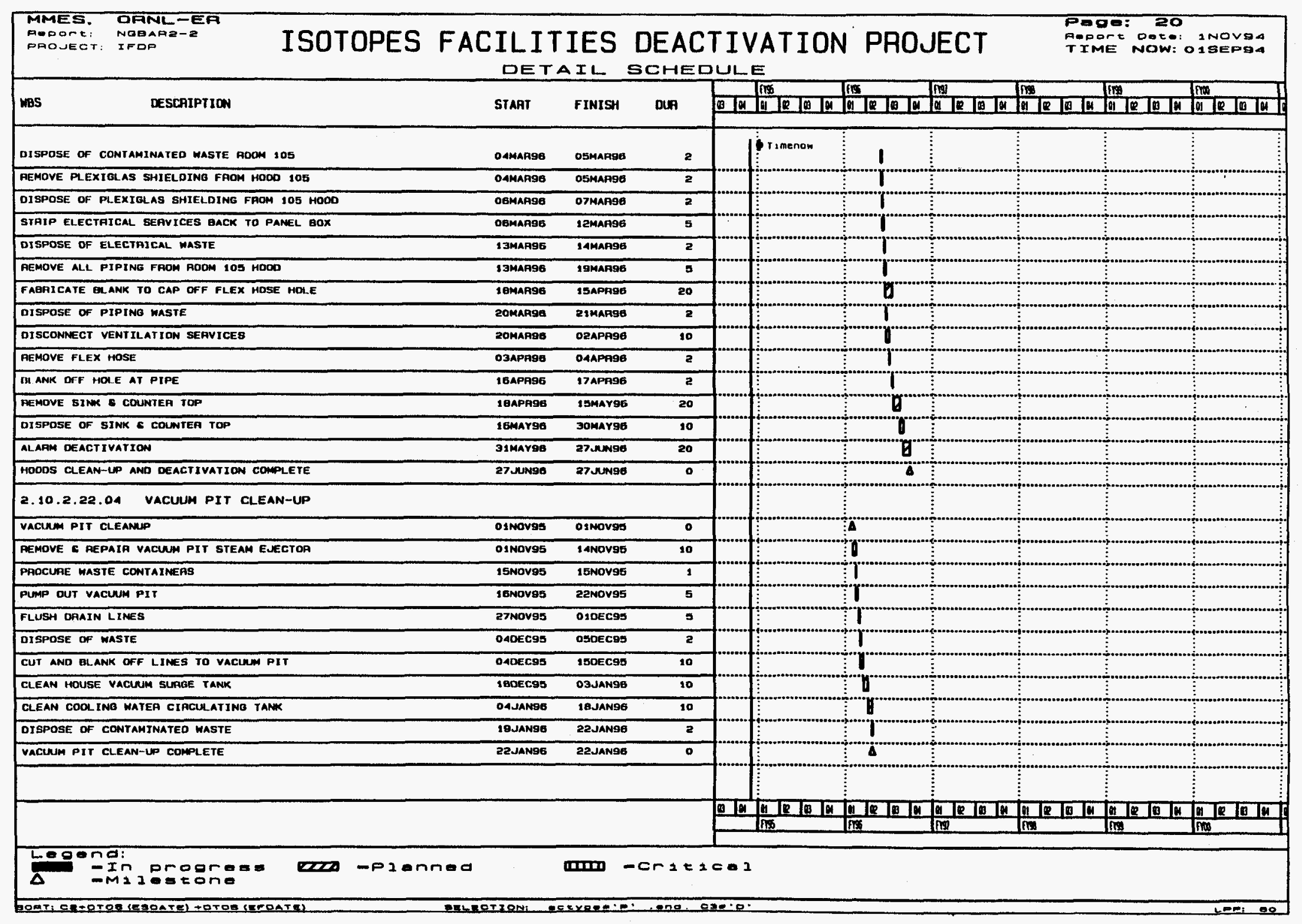




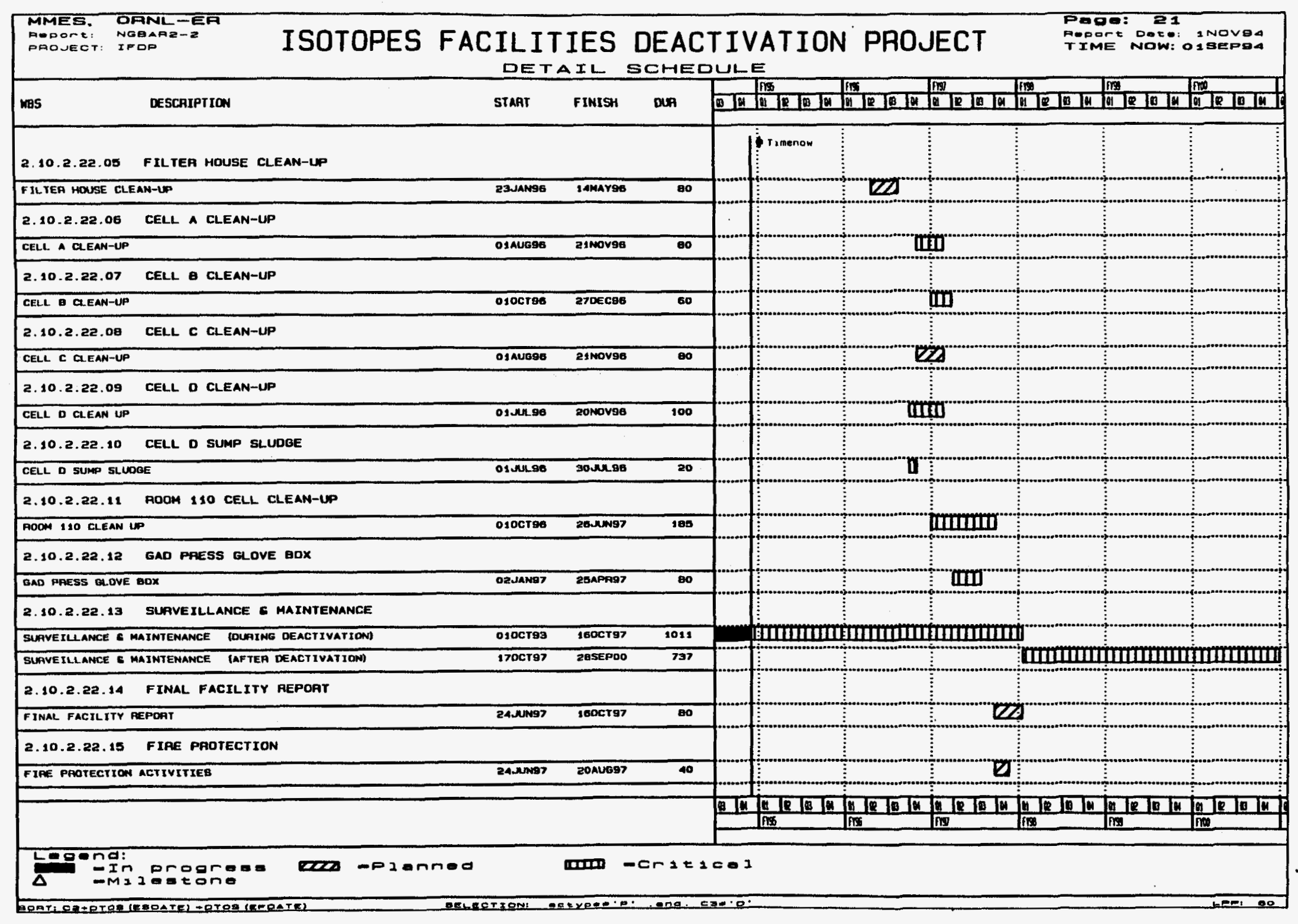




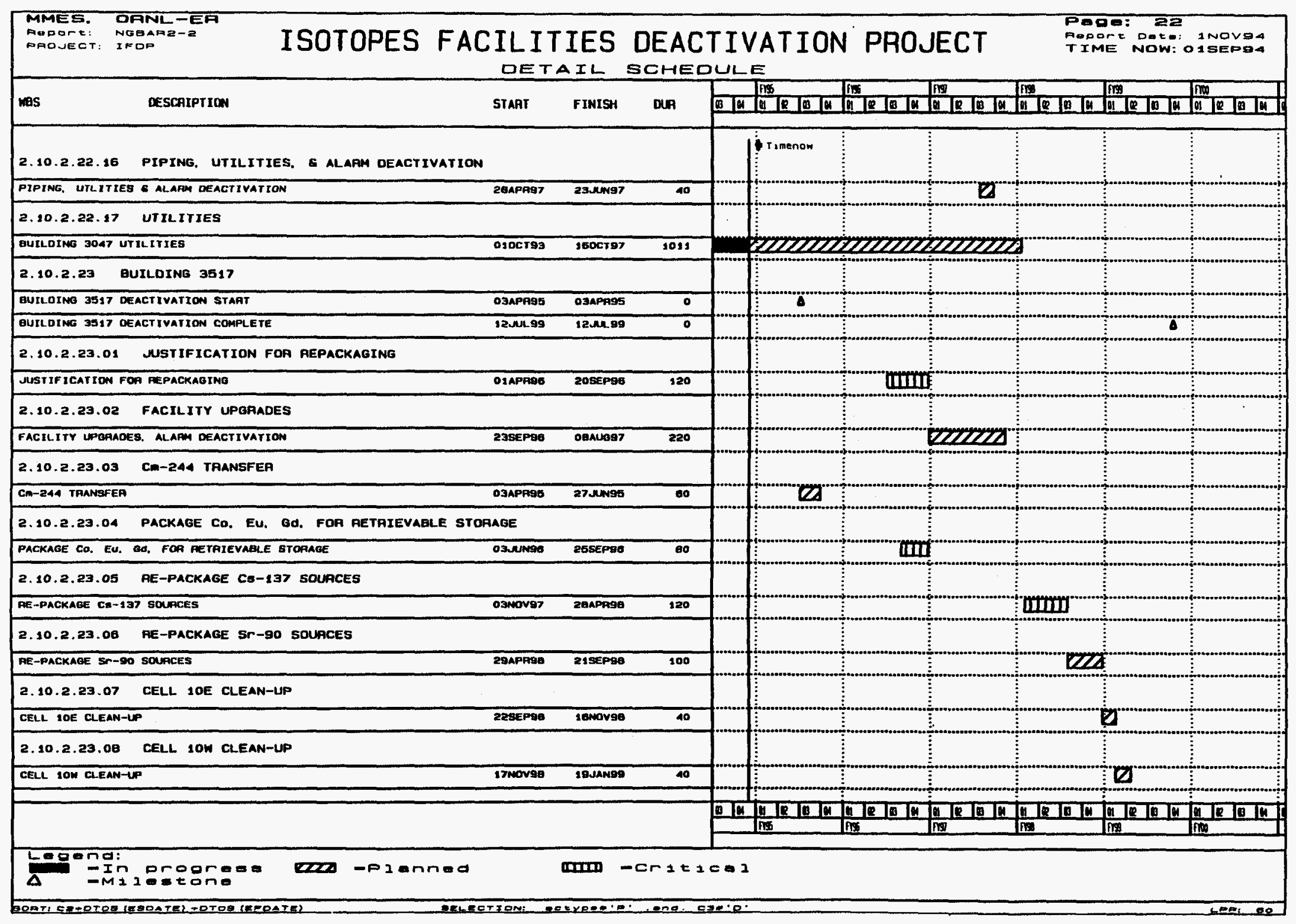




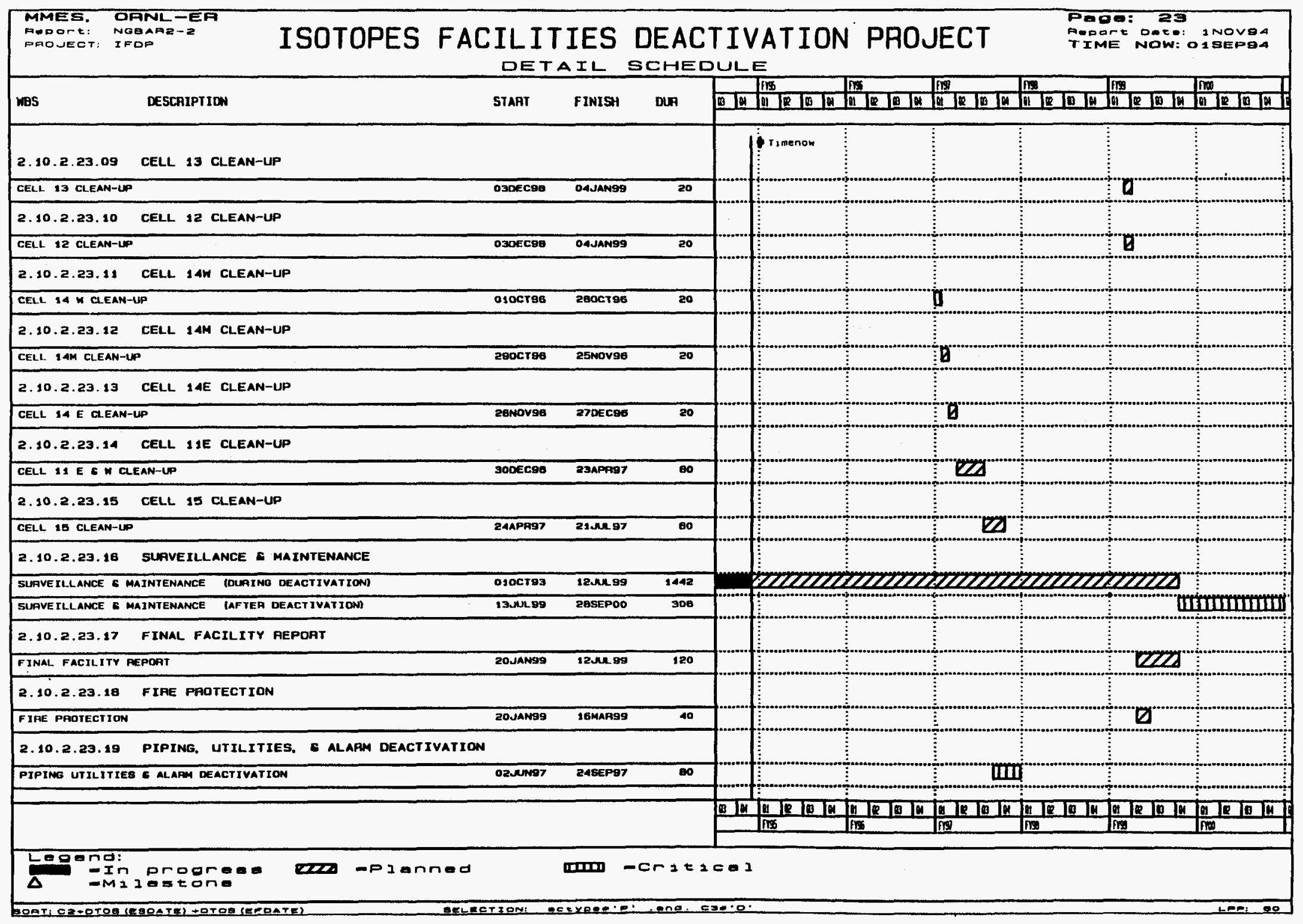




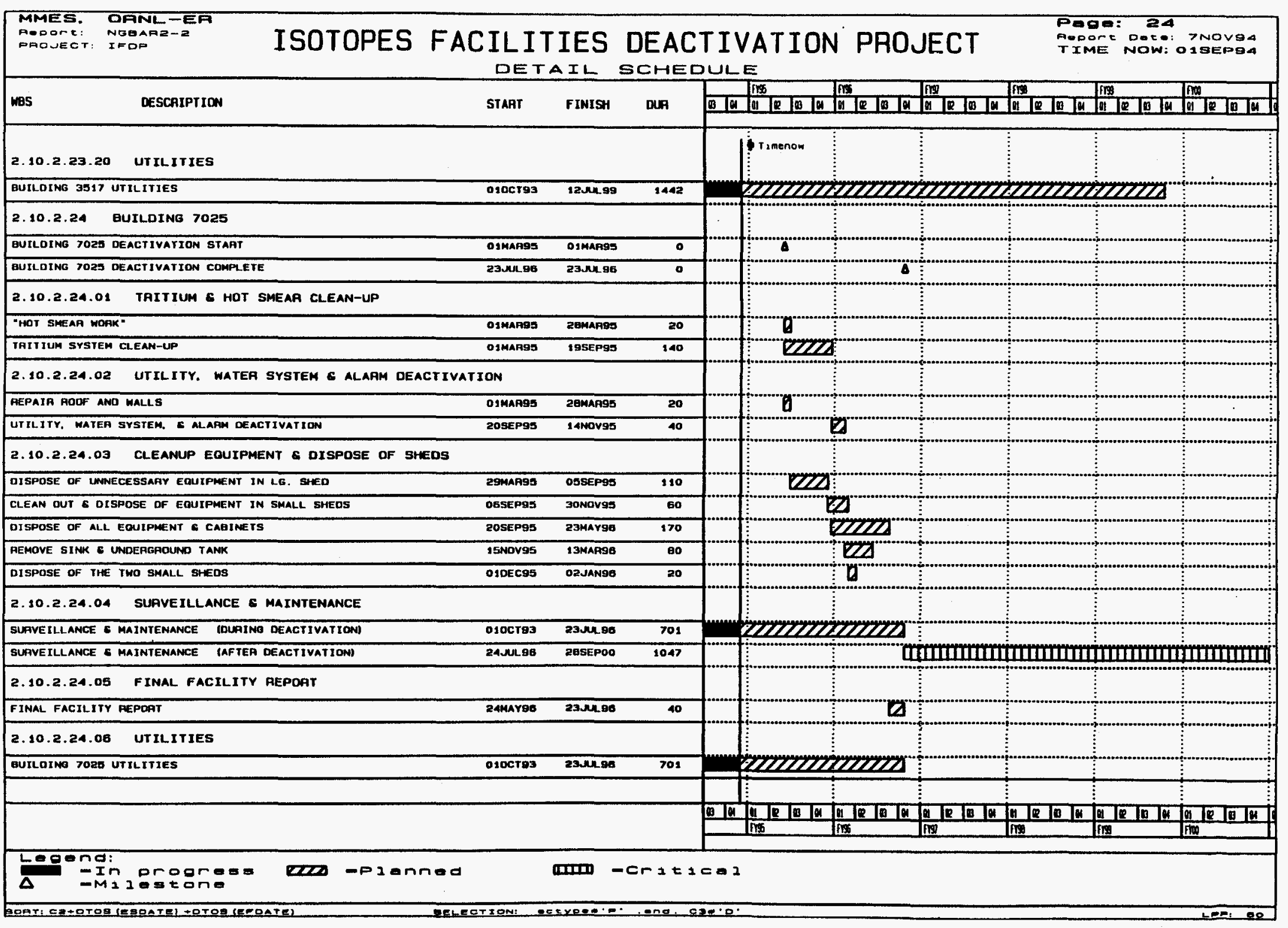


Appendix C

PROJECT COST ESTIMATES 
-

-

- 


\author{
FISCAL YEAR SUMUARY \\ Project Number: 1 \\ ISOTOPE DEACTIVATIOH PROGRAM \\ Project ESO Number.......PXODOKOI \\ Revision Number.......... \\ Last Update............11/07/1994
}

Sort Order

1. Hes - Level 5

Approved by:

Project Estimator

Date

Estimating Manager

Date

Base Fiscal Year/Quarter: $94 / 3$

STAKDARD VALUE: D: WESIERAUG94B.val EXPIRES: 11/08/1995

ESTIMATE FILE: D:WESTISOTOPE LBSLIMEVISOBSLIH.EST 19/07/1994

SCHEDULE FILE: IFDP-C

REPORT FILE: D: WESIISOTOPEX8SLIMEXFYSH.OUT 11/07/1994 16:14:59

AES Version $6.0 f$ 
ISOTOPE DEACTIVATION PROGRAM

FISCAL YEAR SUMMARY

$s 1=\$ 1000$

$11 / 07 / 1994$

Arranged By: Was

Fiscal Year Range $1994-2000$

2.10.2.01.01 PROJECT MUMAGEMENT 2.10.2.01.02 PROJECT PLANWIMG 2.10.2.01.03 ALDITS \& ASSESSWENTS 2.10.2.10.01 RL LIGHT PACKAGING 2.10.2.10.02 TRITIUA LABS 7 \& 16 2.10.2.10.03 CYLINDER OISPOSAL 2.10.2.10.04 KRYPTON COLUMNS $1-4$ 2.10.2.10.05 PIPING, UTILITY \& ALARH OEACT. 2.10.2.10.06 CHILL WATER SYSTEM 2.10.2.10.07 DUCTWORK

2.10.2.10.08 SURVEILLANCE AND maInTENANCE

2.10.2.10.09 FIMAL FACILITY REPORT

2.10.2.10.11 UTILITIES

2.10.2.11.01 CLEAN OUT AND DEACTIVATE CELLS

2.10.2.11.02 PIPING, UTILITY \& ALARM DEACT. 2.10.2.11.03 SURVEILLANCE AND MAINTENANCE

2.10.2.11.04 FIMAL FACILITY REPORT

2.10.2.11.06 UTILITIES

2.10.2.12.01 CLEAHOUT AND DEACTIVATE CELLS

2.10.2.12.02 DEACTIVATE PIPING AND UTILITIE

2.10.2.12.03 sURVEILLAMCE AND MAINTEMANCE

2.10.2.12.04 FIMAL FACILITY REPORT

2.10.2.12.05 FIRE PROTECTIOH

2.10.2.12.06 SEAL EXTERIOR

2.10.2.12.07 UTILITIES

2.10.2.13.01 CLEAMOUT AMO DEACTIVATE CELLS

2.10.2.13.02 CE137 PONDER CLEAN-UP/PB DISP. 2.10.2.13.03 PIPING, UTILITY \& ALARM DEACT. 2.10.2.13.04 SURVEILLAMCE AMO MAIMTEMAMCE

2.10.2.13.05 FIMAL FACILITY REPORT

2.10.2.13.06 FIRE PROTECTION

2.10.2.13.07 SEAL EXTERIOR

2.10.2.13.08 UTILITIES

2.10.2.14.01 CLEAMOUT AMO DEACTIVATE CELLS

2.10.2.14.02 PIPING, UTILITY \& ALARM DEACT. 2.10.2.14.03 SURVEILLANCE AND MUINTENANCE

2.10.2.14.04 FIMAL FACILITY REPORT

2.10.2.14.05 SEAL EXTERIOR

2.10.2.14.06 UTILITIES

2.10.2.15.01 CLEAN UP \& DEACTIVATE CELLS

2.10.2.15.02 DEACT PPG SVCS \& ALARH DEACT

2.10.2.15.03 RE-ROOF BUILOS 3030,3118,3031

\begin{tabular}{|c|c|c|c|c|c|}
\hline 1994 & 1995 & 1996 & 1997 & 1998 & Total \\
\hline 114 & 233 & 241 & 248 & 179 & 1015 \\
\hline 202 & 466 & $\pi$ & 80 & 82 & 907 \\
\hline 51 & 125 & 129 & 133 & 137 & 575 \\
\hline 202 & 108 & • & - & • & 310 \\
\hline . & - & 66 & . & . & 66 \\
\hline . & 78 & • & • & - & 78 \\
\hline - & 54 & - & • & . & 54 \\
\hline - & 70 & • & - & . & 70 \\
\hline . & 30 & . & . & • & 30 \\
\hline . & 12 & - & . & . & 12 \\
\hline 148 & 150 & 98 & 19 & 19 & 434 \\
\hline . & . & 93 & . & . & 93 \\
\hline 67 & 68 & 41 & - & • & 176 \\
\hline . & 134 & 544 & . & . & 678 \\
\hline - & . & 144 & 26 & . & 170 \\
\hline 104 & 106 & 110 & 62 & 23 & 405 \\
\hline . & • & • & 96 & - & 96 \\
\hline 60 & 61 & 63 & 29 & - & 213 \\
\hline 32 & 178 & 65 & . & . & 275 \\
\hline - & . & 42 & • & . & 42 \\
\hline 121 & 124 & 100 & 17 & 18 & $38 \mathrm{C}$ \\
\hline . & . & 94 & . & . & 94 \\
\hline - & • & 85 & • & • & 85 \\
\hline 41 & . & • & - & - & 41 \\
\hline 52 & 53 & 41 & • & - & 146 \\
\hline 56 & 100 & . & . & • & $15 t$ \\
\hline . & 183 & 12 & - & • & 195 \\
\hline . & 35 & . & - & • & 35 \\
\hline 303 & 309 & 138 & 34 & 35 & 815 \\
\hline . & . & 93 & . & . & $9:$ \\
\hline . & • & 90 & • & • & 9 \\
\hline 41 & - & - & - & - & $4^{\circ}$ \\
\hline 55 & 56 & 21 & - & . & $13 ;$ \\
\hline 24 & 109 & • & - & - & 13: \\
\hline 4 & 9 & . & • & . & $1 ?$ \\
\hline 52 & 25 & 3 & 3 & 3 & 86 \\
\hline - & 56 & • & • & - & 56 \\
\hline - & 24 & - & • & - & 24 \\
\hline 36 & 16 & • & • & - & $5:$ \\
\hline • & 14 & • & - & - & 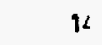 \\
\hline - & 65 & - & - & - & $6 !$ \\
\hline - & 144 & • & - & - & 146 \\
\hline
\end{tabular}


ISOTOPE DEACTIVATION PROGRAM

FISCAL YEAR SUMMARY

$s i=\$ 1000$

$11 / 07 / 1994$

Arranged BY: wBS

Fiscal Year Range 1994 - 2000

2.10.2.15.04 SURVEILLANCE ANO MAIMTENANCE

2.10.2.15.05 FIMAL FACILITY REPORT

2.10.2.15.06 UTILITIES

2.10.2.16.01 CLEAN FLOORS AND SEAL CELLS

2.10.2.16.02 SURVEILLANCE ANO MAITENANCE

2.10.2.16.03 FIMAL FACILITY REPORT

2.10.2.16.06 UTILITIES

2.10.2.17.01 INERT TRITIUN TRAPS

2.10.2.17.02 KRYPTOW EOUIP. ALARM DEACT.

2.10.2.17.03 SURVEILLANCE AND MAINTENANCE

2.10.2.17.06 FIWAL FACILITY REPORT

2.10.2.17.05 SEAL EXTERIOR

2.10.2.18.01 CLEAN \& REMOVE GLOVE BOX \&HOOO

2.10.2.18.02 ROOF REPAIR

2.10.2.18.03 UTIL/ALAR/SYS DUCT/GLV BX DEAC

2.10.2.18.06 SURVEILLANCE AND MAIMTENANCE

2.10.2.18.05 FIMAL FACILITY REPORT

2.10.2.19.01 CELL CLEAH-UP

2.10.2.19.02 UTIL/ALAR/SYS DUCT/GLV8X DEACT

2.10.2.19.03 DRAIN REPAIR

2.10.2.19.04 SURVEILLANCE AND MaIMTEMANCE

2.10.2.19.05 FIMAL FACILITY REPORT

2.10.2.19.06 FIRE PROTECTIOW

2.10.2,19.07 UTILITIES

2.10.2.20.01 SEAL \& RENOVE GLOVE BOXES

2.10.2.20.02 TRITIUN CELL CLEAN-UP

2.10.2.20.03 PPG/UTIL/ALARM DEACT

2.10.2.20.04 SURVEILLANCE AND MIHTENANCE

2.10.2.20.05 FIMAL FACILITY REPORT

2.10.2.20.06 UTILITIES

2.10.2.21.01 PPG/UTIL/ALARM DEACT

2.10.2.21.02 RELOCATE PACKING \& SHIPPING OP

2.10.2.21.03 SURVEILLANCE AND MIHTENANCE

2.10.2.21.04 FIMAL FACILITY REPORT

2.10.2.21.05 UTILITIES

2.10.2.22.01 CHILL WATER SYSTEM

2.10.2.22.02 C-14 GLOVE BOX CLEAN-UP

2.10.2.22.03 h000S

2.10.2.22.04 VACUUN PIT CLEAN-UP

2.10.2.22.05 FILTER HOUSE CLEAMUP

2.10.2.22.06 CELL A CLEAN-UP

2.10.2.22.07 CELL B CLEAN-UP

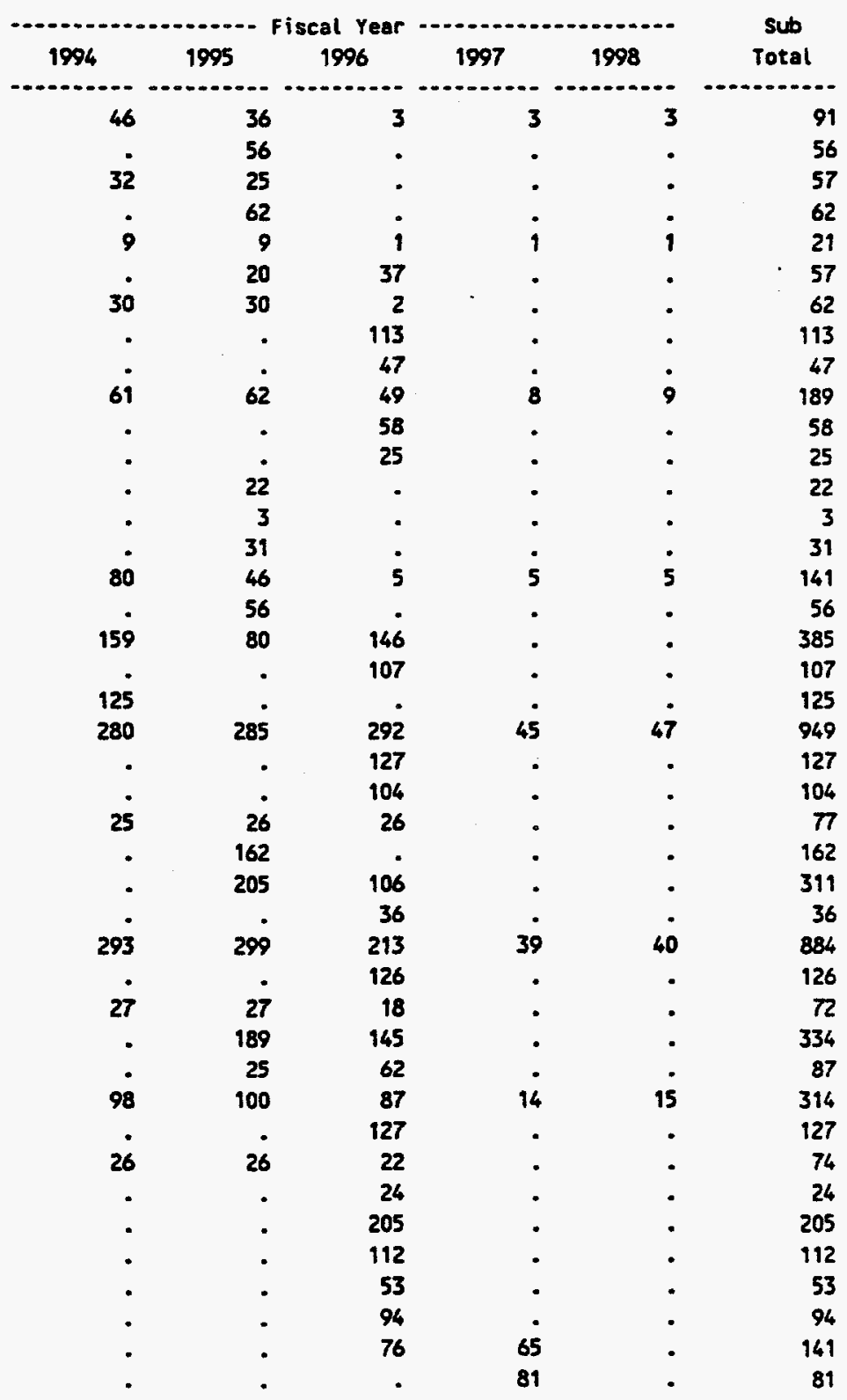


ISOTOPE DEACTIVATION PROGRAM

FISCAL YEAR SUMMARY

$\$ 1=\$ 1000$

$11 / 07 / 1994$

Arranged By: WBS

Fiscal Year Range $1994-2000$

2.10.2.22.08 CELL C CLEAN-UP

2.10.2.22.09 CELL D CLEAM-UP

2.10.2.22.10 CELL D SLLOGE REMOVAL

2.10.2.22.11 ROON 110 CELL CLEAN-UP

2.10.2.22.12 GND PRESS GLOVE BOX

2.10.2.22.13 SURVEILLANCE AND MAINTENANCE

2.10.2.22.14 FIKAL FACILITY REPORT

2.10.2.22.15 FIRE PROTECTION

2.10.2.22.16 PPG/UTIL/ALARH DEACT

2.10.2.22.17 UTILITIES

2.10.2.23.01 JUSTIFICATION FOR REPACKAGING

2.10.2.23.02 FACILITY UPGRADES

2.10.2.23.03 CH-264 TRAMSFER

2.10.2.23.04 PACKAGE CO, EU,CD FOR RETR STG

2.10.2.23.05 RE-PACKAGE CE-137 SOURCES

2.10.2.23.06 RE-PACKAGE SR-90 SOURCES

2.10.2.23.07 CELL 10-E CLEAMUP

2.10.2.23.08 CELL 1OW CLEAN-UP

2.10.2.23.09 CELL 13 CLEAN-UP

2.10.2.23.10 CELL 12 CLENH-UP

2.10.2.23.11 CELL 14H CLEAN-UP

2.10.2.23.12 CELL 14H CLEAN-UP

2.10.2.23.13 CELL 14E CLEAN-UP

2.10.2.23.14 CELL 11E CLEAN-UP

2.10.2.23.15 CELL 15 CLEAN-UP

2.10.2.23.16 SURVEILLANCE AND maINTENANCE

2.10.2.23.17 FIMAL FACILITY REPORT

2.10.2.23.18 FIRE PROTECTION

2.10.2.23.19 PPG/UTIL/ALARM DEACT

2.10.2.23.20 UTILITIES

2.10.2.24.01 TRITIUW \& HOT SMEAR CLEAN UP

2.10.2.26.02 WATER SYS \& ALARM DEACT

2.10.2.26.03 CLEAMUP EQUIP \& DISP OF SHEDS

2.10.2.24.04 SURVEILLANCE AND maInTENANCE

2.10.2.24.05 FINAL FACILITY REPORT

2.10.2.24.06 UTILITIES

\begin{tabular}{|c|c|c|c|c|c|}
\hline 1994 & 1995 & $\begin{array}{l}\text { al Year } \\
1996\end{array}$ & 1997 & 1998 & $\begin{array}{l}\text { Sub } \\
\text { Total }\end{array}$ \\
\hline . & $-\infty$ & 76 & 65 & 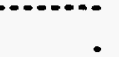 & 141 \\
\hline - & . & 110 & 61 & . & 171 \\
\hline - & - & 163 & - & - & 163 \\
\hline - & . & . & 330 & . & 330 \\
\hline . & . & . & 197 & . & 117 \\
\hline 554 & 565 & 585 & 602 & 190 & 2496 \\
\hline . & - & • & 113 & 18 & 131 \\
\hline : & . & . & 63 & . & 63 \\
\hline . & . & . & 352 & . & 352 \\
\hline 138 & 141 & 146 & 150 & 7 & 582 \\
\hline - & - & 90 & - & - & 90 \\
\hline - & - & 39 & 1554 & . & 1593 \\
\hline - & 132 & - & . & - & 132 \\
\hline - & - & 132 & - & - & 132 \\
\hline - & - & - & - & 591 & 591 \\
\hline - & - & - & - & 776 & 776 \\
\hline - & - & - & - & 5 & 5 \\
\hline - & - & - & - & - & 0 \\
\hline - & - & - & - & - & 0 \\
\hline • & . & . & . & . & 0 \\
\hline . & . & . & 21 & . & 21 \\
\hline - & - & - & 21 & - & 21 \\
\hline - & - & - & 21 & - & 21 \\
\hline - & - & - & 111 & - & 111 \\
\hline - & . & . & 64 & . & 64 \\
\hline 638 & 650 & 673 & 692 & 714 & 3367 \\
\hline - & - & - & - & - & 0 \\
\hline . & . & . & . & . & 0 \\
\hline . & . & . & 354 & . & 354 \\
\hline 157 & 161 & 166 & 171 & 176 & 831 \\
\hline - & 123 & - & - & - & 123 \\
\hline - & 5 & 5 & - & - & 10 \\
\hline - & 18 & 40 & - & - & 58 \\
\hline 68 & 69 & 60 & 10 & 10 & 217 \\
\hline • & . & 58 & . & . & 58 \\
\hline 13 & 13 & 11 & - & . & 37 \\
\hline
\end{tabular}


ISOTOPE DEACTIVATION PROGRAM

FISCAL YEAR SUMARARY

$\$ 1=\$ 1000$

$11 / 07 / 1994$

Arranged By: wBS

Fiscal Year Range 1994 - 2000

Sub-Total

Overhead

Sub-Total

Contingency

Grand Total

\begin{tabular}{|c|c|c|c|c|c|}
\hline 1994 & 1995 & 1996 & 1997 & 1998 & Total \\
\hline 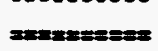 & = & 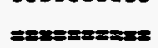 & 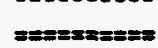 & 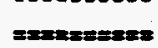 & 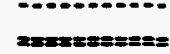 \\
\hline 4624 & 6954 & 7392 & 5880 & 3103 & 27953 \\
\hline 2025 & 3035 & 3157 & 2548 & 1338 & 12103 \\
\hline$\rightarrow$ & - & $=2 x=2=x=$ & $y= \pm== \pm x$ & 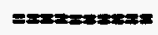 & 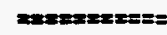 \\
\hline 6649 & 9989 & 10549 & 8428 & 4449 & 40056 \\
\hline 1995 & 2997 & 3164 & 2528 & 1333 & 12017 \\
\hline & & 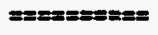 & & & 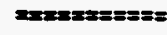 \\
\hline 8644 & 12986 & 13713 & 10956 & 5774 & 52073 \\
\hline
\end{tabular}


ISOTOPE DEACTIVATION PROGRAM

FISCAL YEAR SUMMARY

$S 1=\$ 1000$

$19 / 07 / 1994$

Arranged 8Y: WBS

fiscal Year Range $1994 \cdot 2000$

2.10.2.01.01 PROJECT MANAGEMENT

2.10.2.01.02 PROJECT PLAMMING

2.10.2.01.03 ALOITS \& ASSESSHENTS

2.10.2.10.01 RL LIGHT PACXAGING

2.10.2.10.02 TRITIUM LABS $7 \& 16$

2.10.2.10.03 CYLINDER DISPOSAL

2.10.2.10.04 XRYPTON COLLANS $1-4$

2.10.2.10.05 PIPIHG, UTILITY \& ALARH DEACT.

2.10.2.10.06 CHILL WATER SYSTEM

2.10.2.10.07 DUCTWORK

2.10.2.10:08 SURVEILLANCE AMD MAINTEMANCE

2.10.2.10.09 FIMAL FACILITY REPCRT

2.10.2.10.11 UTILITIES

2.10.2.11.01 CleAN OUT AND DEACTIVATE CELLS 2.10.2.11.02 PIPIMG, UTILITY \& ALARM DEACT.

2.10.2.11.03 SURVEILLANCE AMD MAINTEMANCE

2.10.2.11.04 FIMAL FACILITY REPORT

2.10.2.11.06 UTILITIES

2.10.2.12.01 CLEAMOUT AND DEACTIVATE CELLS

2.10.2.12.02 DEACTIVATE PIPING AND UTILITIE

2.10.2.12.03 SURVEILLANCE AND MAINTENANCE

2.10.2.12.04 FIMAL FACILITY REPORT

2.10.2.12.05 FIRE PROTECTIOM

2.10.2.12.06 SEAL EXTERIOR

2.10.2.12.07 UTILITIES

2.10.2.13.01 CLEANOUT AND dEACTIVATE CELLS

2.10.2.13.02 CE137 PONOER CLEAN-UP/PB DISP.

2.10.2.13.03 PIPING, UTILITY \& ALARH DEACT.

2.10.2.13.04 sURVEILLANCE AND mintemaNCE

2.10.2.13.05 FIMAL FACILITY REPORT

2.10.2.13.06 FIRE PROTECTION

2.10.2.13.07 SEAL EXTERIOR

2.10.2.13.08 UTILITIES

2.10.2.14.01 CLEAMOUT AMD DEACTIVATE CELLS

2.10.2.14.02 PIPING, UTILITY \& ALARM DEACT.

2.10.2.14.03 SURVEILLANCE AND MAIHTENANCE

2.10.2.14.04 FINAL FACILITY REPORT

2.10.2.14.05 SEAL EXTERIOR

2.10.2.94.06 UTILITIES

2.10.2.15.01 CLEAM UP DEACTIVATE CELLS

2.10.2.15.02 DEACT PPG SVCS \& ALARM DEACT

2.10.2.15.03 RE-ROOF BUILOS 3030,3118,3031

\begin{tabular}{|c|c|c|}
\hline 1999 & 2000 & Total \\
\hline 185 & . & 1200 \\
\hline 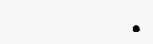 & . & 907 \\
\hline - & . & 575 \\
\hline - & . & 310 \\
\hline 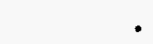 & . & 66 \\
\hline . & . & 78 \\
\hline$\bullet$ & . & 54 \\
\hline • & $\cdot$ & 70 \\
\hline 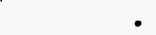 & $\cdot$ & 30 \\
\hline 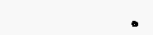 & - & 12 \\
\hline 20 & 21 & 475 \\
\hline • & - & 93 \\
\hline • & - & 176 \\
\hline - & - & 678 \\
\hline 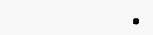 & . & 170 \\
\hline 23 & 24 & 452 \\
\hline${ }^{\circ}$ & • & 96 \\
\hline • & - & 213 \\
\hline . & - & 275 \\
\hline • & . & 42 \\
\hline 18 & 19 & 417 \\
\hline • & • & 94 \\
\hline • & - & 85 \\
\hline • & - & 41 \\
\hline - & - & 146 \\
\hline - & - & 156 \\
\hline . & $\cdot$ & 195 \\
\hline . & . & 35 \\
\hline 36 & 37 & 892 \\
\hline - & - & 93 \\
\hline • & - & 90 \\
\hline • & - & 41 \\
\hline • & - & 132 \\
\hline - & - & 133 \\
\hline - & $\bullet$ & 13 \\
\hline 3 & 3 & 92 \\
\hline - & - & 56 \\
\hline - & $\bullet$ & 24 \\
\hline - & - & 52 \\
\hline - & - & 14 \\
\hline • & - & 65 \\
\hline - & - & 144 \\
\hline
\end{tabular}


ISOTOPE DEACTIVATION PROGRAM

FISCAL YEAR SUMWARY

$\$ 1=\$ 1000$

$11 / 07 / 1994$

Arranged BY: WBS

Fiscal Year Range $1994-2000$

2.10.2.15.04 SURVEILLANCE AND MAINTEMAMCE 2.10.2.15.05 FIMAL FACILITY REPORT 2.10.2.15.06 UTILITIES

2.10.2.16.01 CLEN FLOORS AND SEAL CELLS 2.10.2.16.02 SURVEILLANCE AND MAINTENANCE 2.10.2.16.03 FIMAL FACILITY REPORT

2.10.2.16.04 UTILITIES

2.10.2.17.01 INERT TRITIUH TRAPS

2.10.2.17.02 KRYPTON EQUIP. \& ALARM DEACT. 2.10.2.17.03 SURVEILLANCE AMD MAINTEMANCE

2.10.2.17.04 FIMAL FACILITY REPCRT

2.10.2.17.05 SEAL EXTERIOR

2.10.2.18.01 CLEAN \& REMOVE GLOVE BOX \$HOOO 2.10.2.18.02 ROOF REPAIR

2.10.2.18.03 UTIL/ALAR/SYS DUCT/GLV BX OEAC

2.10.2.18.04 SURVEILLAMCE AND MAINTEMANCE

2.10.2.18.05 FIMAL FACILITY REPCRT

2.10.2.19.01 CELL CLEAN-UP

2.10.2.19.02 UTIL/ALAR/SYS DUCT/GLYBX DEACT

2.10.2.19.03 DRAIM REPAIR

2.10.2.19.04 SURVEILLANCE AND MaInTEMANCE

2.10.2.19.05 FIMAL FACILITY REPORT

2.10.2.19.06 FIRE PROTECTION

2.10.2.19.07 UTILITIES

2.10.2.20.01 SEAL REMOVE GLOVE BOXES

2.10.2.20.02 TRITIUN CELL CLEAN-UP

2.10.2.20.03 PPG/UTIL/ALARM DEACT

2.10.2.20.04 SURVEILLANCE AND MAINTEMANCE

2.10.2.20.05 FIMAL FACILITY REPORT

2.10.2.20.06 UTILITIES

2.10.2.21.01 PPG/UTIL/ALARM DEACT

2.10.2.21.02 RELOCATE PACKING \& SHIPPING OP

2.10.2.21.03 SURVEILLAMCE AND MAINTENANCE

2.10.2.21.04 FIMAL FACILITY REPORT

2.10.2.21.05 UTILITIES

2.10.2.22.01 CHILL MATER SYSTEM

2.10.2.22.02 C-14 GLOVE BOX CLEAN-UP

2.10.2.22.03 h000S

2.10.2.22.04 VACWN PIT CLEAN-UP

2.10.2.22.05 FILTER HOUSE CLEAHUP

2.10.2.22.06 CELL A CLEAN-UP

2.10.2.22.07 CELL B CLEAN-UP

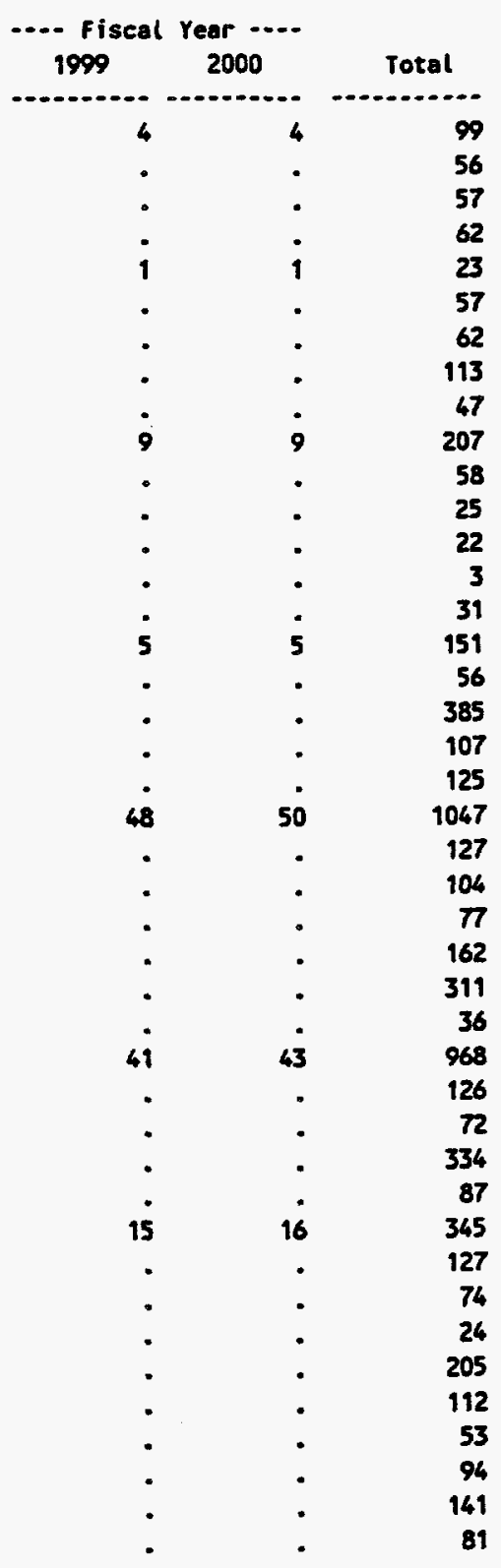


ISOTOPE DEACTIVATION PROGRAM

FISCAL YEAR SUMMARY

$\$ 1=\$ 1000$

$11 / 07 / 1994$

Arranged By: was

Fiscal Year Range 1994 - 2000

2.10.2.22.08 CELL C CLEAN-UP

2.10.2.22.09 CELL D CLEAN-UP

2.10.2.22.10 CELL D SLUDGE REMOVAL

2.10.2.22.11 ROOH 110 CELL CLEAN-UP

2.10.2.22.12 GAD PRESS GLOVE BOX

2.10.2.22.13 SURVEILLAMCE AMD MIINTEMAMCE

2.10.2.22.14 FIMAL FACILITY REPORT

2.10.2.22.15 FIRE PROTECTION

2.10.2.22.16 PPG/UTIL/ALARH DEACT

2.10.2.22.17 UTILITIES

2.10.2.23.01 JUSTIFICATION FOR REPACKAGING

2.10.2.23.02 FACILITY UPGRADES

2.10.2.23.03 CM-244 TRANSFER

2.10.2.23.04 PACKAGE CO, EU,CO FOR RETR STG

2.10.2.23.05 RE-PACKAGE CE-137 SOURCES

2.10.2.23.06 RE-PACKAGE SR-90 SOURCES

2.10.2.23.07 CELL 10-E CLEAMUP

2.10.2.23.08 CELL 10N CLEAN-UP

2.10.2.23.09 CELL 13 CLEAH-UP

2.10.2.23.10 CELL 12 CLEAM-UP

2.10.2.23.11 CELL 16H CLEAM-UP

2.10.2.23.12 CELL 14W CLEAN-UP

2.10.2.23.13 CELL 14E CLEAN-UP

2.10.2.23.14 CELL I1E CLEAN-UP

2.10.2.23.15 CELL 15 CLEAN-UP

2.10.2.23.16 SURVEILLANCE AND MALNTEMANCE

2.10.2.23.17 FIMAL FACILITY REPORT

2.10.2.23.18 FIRE PROTECTION

2.10.2.23.19 PPG/UTIL/ALARM DEACT

2.10.2.23.20 UTILITIES

2.10.2.24.01 TRITIUN \& HOT SHEAR CLEAN UP

2.10.2.24.02 UATER SYS \& ALARH DEACT

2.10.2.24.03 CLEANUP EQUIP \& DISP OF SHEDS

2.10.2.24.04 SURVEILLAMCE AND MINTENANCE

2.10.2.24.05 FIMLL FACILITY REPORT

2.10.2.24.06 UTILITIES

\begin{tabular}{|c|c|c|}
\hline 1999 & 2000 & Total \\
\hline & & 141 \\
\hline . & 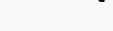 & 171 \\
\hline 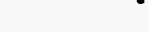 & 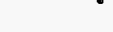 & 163 \\
\hline 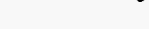 & 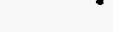 & 330 \\
\hline - & - & 117 \\
\hline & 29 & \\
\hline 176 & 181 & 2853 \\
\hline - & - & 131 \\
\hline - & - & 63 \\
\hline - & - & 352 \\
\hline - & - & 582 \\
\hline - & - & 90 \\
\hline - & • & 1593 \\
\hline • & • & 132 \\
\hline - & • & 132 \\
\hline • & • & 591 \\
\hline - & • & 776 \\
\hline 27 & - & 32 \\
\hline 33 & • & 33 \\
\hline 43 & • & 43 \\
\hline 44 & • & 44 \\
\hline - & • & 21 \\
\hline - & - & 21 \\
\hline - & • & 21 \\
\hline - & • & 111 \\
\hline • & • & 64 \\
\hline 729 & 721 & 4817 \\
\hline 220 & • & 220 \\
\hline 153 & - & 153 \\
\hline • & • & 354 \\
\hline 142 & • & 973 \\
\hline 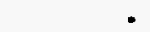 & • & 123 \\
\hline • & - & 10 \\
\hline 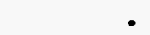 & • & 58 \\
\hline 11 & 11 & 239 \\
\hline 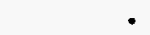 & • & 58 \\
\hline • & 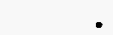 & 37 \\
\hline
\end{tabular}




\section{C-11}

ISOTOPE DEACTIVATION PROGRAN

FISCAL YEAR SUAMARY

$\$ 1=\$ 1000$

$11 / 07 / 1994$

Arranged By: wBS

Fiscal Year Range $1994-2000$

Sub-Total

overhead

Sub-Total

Contingency

Grand Total

\begin{tabular}{|c|c|c|}
\hline 1999 & 2000 & Total \\
\hline 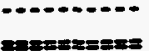 & $x=-$ & $=$ \\
\hline 1986 & 1145 & 31084 \\
\hline 831 & 503 & 13437 \\
\hline$=x=$ & 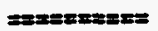 & 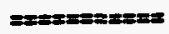 \\
\hline 2817 & 1648 & 44521 \\
\hline 845 & 494 & 13356 \\
\hline & $= \pm=$ & 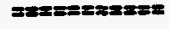 \\
\hline$\$ 662$ & 2142 & 57877 \\
\hline
\end{tabular}




\section{DISTRIBUTION}

1. J. W. Autrey

2. C. A Bednarz

3. J. B. Berry

4. T. Bonine

5. H. L Boston

6. W. D. Brickeen

7. T. W. Burwinlle

8. C. Clark, Jr.

9. K. Constant

10. A. G. Croff

11. R. E. Eversole

12. S. B. Garland

13. K. W. Haff

14. J. H. Hooyman

15. L L Kaiser

16. K A. Keller

17. E A Krispin

18. A. J. Kuhaida

19. R. C. Mason

20. T. J. Newsom

21-22. P. T. Owen
23. L D. Owens

24. R. S. Owens

25. B. D. Patton

26. P. A Pehlman

27. H. X Phillips

28. D. W. Ramey

29. P. D. Ramsey

30. S. M. Robinson

31. P. A. Schrandt

32. B. H. Singletary

33. S. D. Van Hoesen

34. A B. Walker

35. M. L Whitehead

36. A. C. Williamson

37. P. S. Wood

38. ORNL ER Doc. Manage. Center

39. Central ER Doc. Manage. Center

40. Laboratory Records Dept.

41. ORNL Patent Section

42. Central Research Library

43. Office of Assistant Manager for Energy Research and Development, DOE Oak Ridge Operations Office, P.O. Box 2001, Oak Ridge, TN 37831-8600

44-45. Office of Scientific and Technical Information, P.O. Box 62, Oak Ridge, TN 37831

46. V. F. Boston, DOE Oak Ridge Operations Office, P.O. Box 2001, Oak Ridge, TN 37831-8541

47. C. S. Gist, DOE Oak Ridge Operations Office, P.O. Box 2001, Oak Ridge, TN 37831-8541 